Prepared in cooperation with the International Association of Limnogeology

\title{
Sixth International Limnogeology Congress- Field Trip Guidebook, Reno, Nevada, June 15-19, 2015
}

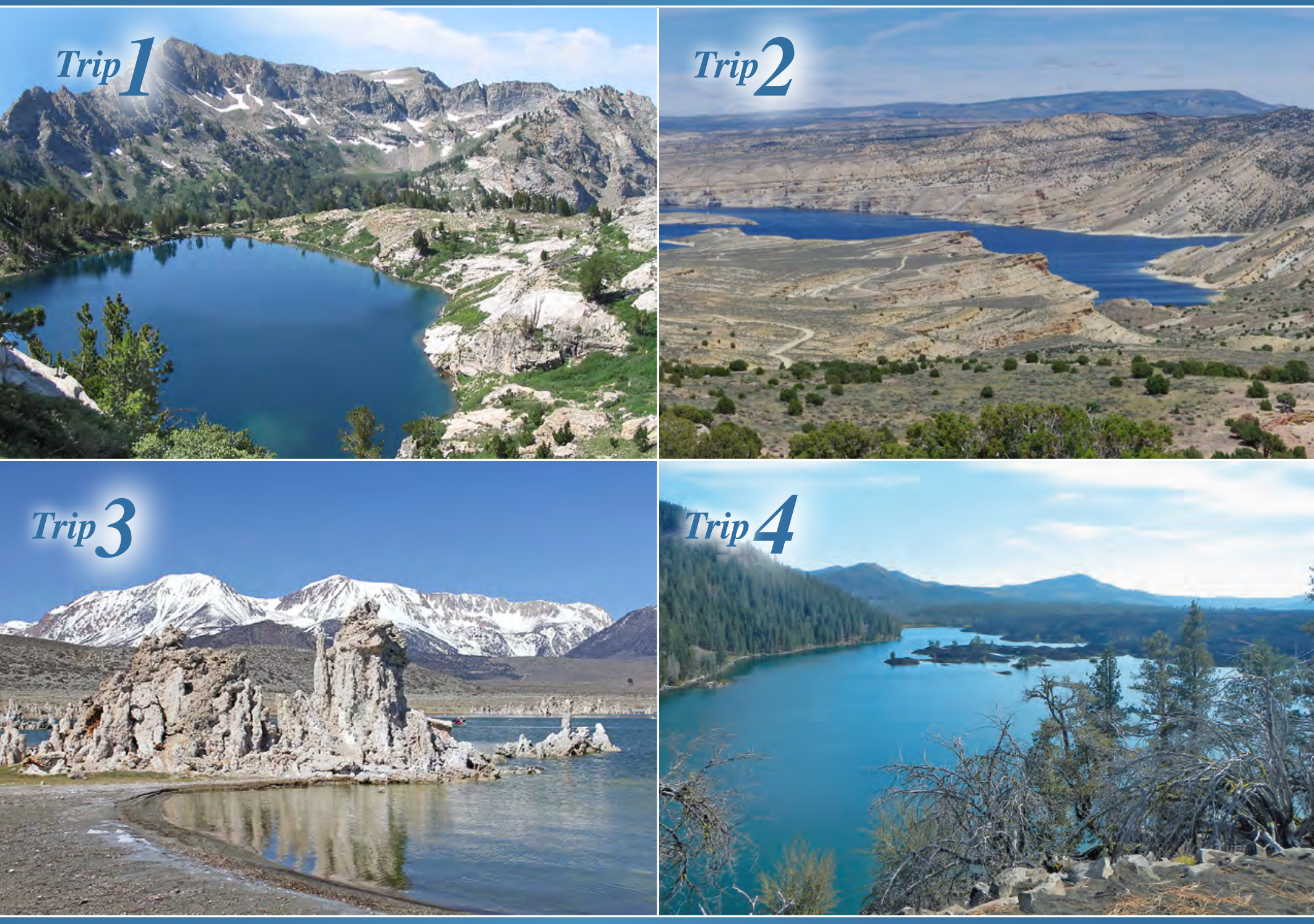

Open-File Report 2015-1108

U.S. Department of the Interior U.S. Geological Survey
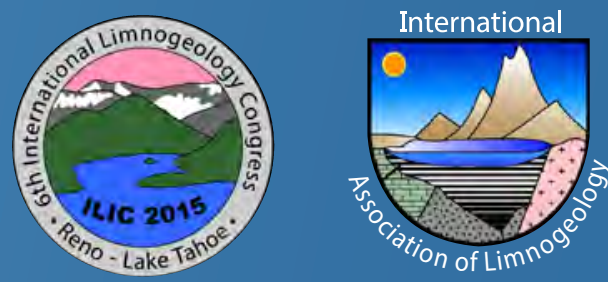
Cover:

Trip 1. Photograph of the alpine landscape in the Ruby Mountains. Liberty Lake in the foreground. Photograph by Jeff Munroe, Middlebury College, Vermont, July 29, 2006.

Trip 2. Photograph of the 'Pipeline section', which exposes the entire Green River Formation adjacent to the Uinta Uplift. Strata are folded into a monocline above the blind Henrys Fork reverse fault. Photograph by Jennifer Scott, Mount Royal University, Alberta, Canada, summer 2014.

Trip 3. Photograph showing view of Mono Lake at South Tufa looking west to the Sierra Nevada Mountains. Pleistocene glacial moraines and valleys can be seen in the background. Photograph by Michael R. Rosen, U.S. Geological Survey, May 1, 2011.

Trip 4. Photograph showing Butte Lake from trail on northeastern shore near Butte Creek. Photograph by Kerry Howard, University of Nevada, June 2012. 


\section{Sixth International Limnogeology Congress- Field Trip Guidebook, Reno, Nevada, June 15-19, 2015}

Compiled by Michael R. Rosen

Prepared in cooperation with the International Association of Limnogeology

Open-File Report 2015-1108 


\title{
U.S. Department of the Interior SALLY JEWELL, Secretary
}

\section{U.S. Geological Survey \\ Suzette M. Kimball, Acting Director}

\author{
U.S. Geological Survey, Reston, Virginia: 2015
}

For more information on the USGS - the Federal source for science about the Earth, its natural and living resources, natural hazards, and the environment—visit http://www.usgs.gov or call 1-888-ASK-USGS.

For an overview of USGS information products, including maps, imagery, and publications, visit http://www.usgs.gov/pubprod/.

Any use of trade, firm, or product names is for descriptive purposes only and does not imply endorsement by the U.S. Government.

Although this information product, for the most part, is in the public domain, it also may contain copyrighted materials as noted in the text. Permission to reproduce copyrighted items must be secured from the copyright owner.

Field trips by non-U.S. Geological Survey (USGS) authors in this volume are published as they were submitted. Field trips authored entirely by non-USGS authors do not represent the views or position of the USGS or the U.S. Government and are published solely as part of this volume.

Suggested citation:

Rosen, M.R., compiler, 2015, Sixth International Limnogeology Congress-Field Trip Guidebook, Reno, Nevada, June 15-19, 2015: U.S. Geological Survey Open-File Report 2015-1108, 100 p., http://dx.doi.org/10.3133/ ofr20151108.

Suggested individual trip citation:

Howard, K.L., and Noble, P.J., 2015, Trip 4-Subalpine Lakes in an active volcanogenic setting (Lassen Volcanic National Park, California), in Rosen, M.R., compiler, Sixth International Limnogeology Congress-Field Trip Guidebook, Reno, Nevada, June 15-19, 2015: U.S. Geological Survey Open-File Report 2015-1108, p. 89-100, http://dx.doi. org/10.3133/ofr20151108.

ISSN 2331-1258 (online) 


\section{Preface}

Limnogeology is the study of modern lakes and lake deposits in the geologic record. Limnogeologists have been active since the 1800s, but interest in Limnogeology became prevalent in the early 1990s when it became clear that lake deposits contain continental environmental and climate records. A society that is focused on Limnogeology would allow greater communication and access to research on these important subjects and contribute to providing sound science used to understand rapid global changes in our modern world; thus the International Association of Limnogeology was founded in 1995 at the first International Limnogeology Congress (ILIC) held in Copenhagen, Denmark.

The Sixth International Limnogeology Congress (ILIC6) was held in Reno, Nevada, from June 15-19, 2015. The ILIC meetings have been held every 4 years since the first meeting in 1995 and were subsequently convened in Brest, France (1999), Tucson, USA (2003), Barcelona, Spain (2007), and Konstanz, Germany (2011). The Congress in Reno, USA marks the second time the Congress has been held in the United States and more than 150 scientists from every part of the world participated.

The field trips by USGS authors in this Field Trip Guidebook were peer reviewed and approved for publication by the U.S. Geological Survey. Field trips submitted by non-USGS authors did not go through the formal USGS peer review and approval process, and therefore may not adhere to our editorial standards or stratigraphic nomenclature and is not research conducted or data collected by the USGS. However, all field trips had at a minimum one peer review, and all field trips were edited for consistency of appearance in the published Field Trip Guidebook

As part of the Congress, ILIC6 included pre- and post- Congress field trips, the descriptions of which are included as separate trips in this Open-File Report. Trip 1 provides information on the pluvial and post-glacial Lakes of the eastern Great Basin, led by Paul Jewell, University of Utah, Ben Laabs, State University of New York-Geneseo, Jeff Munroe, Middlebury College, and Jack Oviatt, Kansas State University. Trip 2 contains information on the lake sequences of closed-basin lakes in the Eocene Green River Formation in Wyoming, led by Michael Smith, Northern Arizona University and Jennifer Scott, Mount Royal University. Trip 3 provides the background for the field trip to Pleistocene and modern lakes in the Great Basin of North America that was led by Susan Zimmerman, Lawrence Livermore National Laboratory, Ken Adams, Desert Research Institute, and Michael Rosen, U.S. Geological Survey. Trip 4 contains the information for a trip to the modern lakes in Lassen National Park that was led by Paula Noble and Kerry Howard, both from the University of Nevada, Reno.

Not included in this report are two short (1 day or less) field trips that were more informal than the longer preand post- Congress trips. These trips were a (1) mid-Congress half-day field trip to Lake Tahoe, led by Sudeep Chandra, University of Nevada, Reno, and Alan Heyvaert, Desert Research Institute, that illustrated the water resource issues that prevent degradation of the lake and provide potable water to inhabitants, invasive species concerns, and the limnogeologic history of the lake, and (2) a post-Congress 1-day field trip to Pyramid Lake, led by Brian Wadsworth, Pyramid Lake Paiute Tribe, Ken Adams, and Alan Heyvaert that gave participants information on the water resource issues with the lake, Pyramid Lake Paiute Tribal history and culture, and the limnogeology of the lake.

The U.S. Geological Survey has sponsored each ILIC that has been held in the United States because of the importance of understanding paleoclimate and contaminant histories of lakes, two main themes of the Congress. This field trip guide provides a permanent record of some of the wide variety of studies that are being conducted in modern lakes and ancient lake deposits in western North America, and it provides a starting point for any one desiring to visit these exceptional sites or begin work in these areas. 


\section{Acknowledgments}

The leaders of the individual field trips would like to thank the participants of the field trips that made these trips possible. We would also like to thank Tina Triplett (Nevada Water Resources Association) and her team for helping to organize some of the lodging and vehicles needed for the trips. We would also like to thank the ILIC6 organizing committee and the many sponsors of the meeting for contributing to the success of the Congress. Finally, the stellar work of Linda Rogers and her team at the USGS Science Publishing Network lifted much of the burden off of the authors and the compiler. 


\section{Contents}

Trip 1. New Investigations of Pleistocene Pluvial and Glacial Records from the Northeastern Great Basin 1

DAY 1. Introduction to Lake Bonneville................................................................................

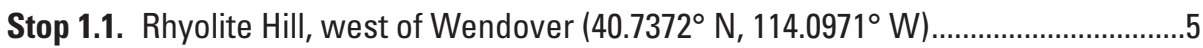

DAY 2. Pluvial Lake Bonneville ........................................................................................6

Stop 2.1. Quartzite Hill $\left(40.8363^{\circ} \mathrm{N}, 113.8933^{\circ} \mathrm{W}\right)$.........................................................

Stop 2.2. Donner-Reed Pass $\left(41.0106^{\circ} \mathrm{N}, 113.7814^{\circ} \mathrm{W}\right)$..............................................

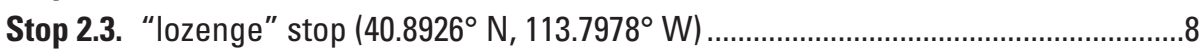

Stop 2.4. Trackhoe trench at Jukebox Cave $\left(40.754915^{\circ} \mathrm{N}, 114.010204^{\circ} \mathrm{W}\right) \ldots \ldots \ldots \ldots \ldots \ldots . . . . .9$

DAY 3. Pluvial Lake Franklin ...........................................................................................10

Stop 3.1. Ruby Lake National Wildlife Refuge and Pluvial Lake Franklin

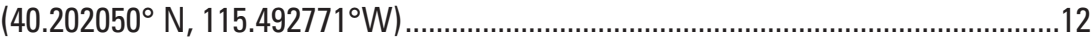

Stop 3.2. Ruby Lake National Wildlife Refuge Gravel Pit $\left(40.178605^{\circ}\right.$

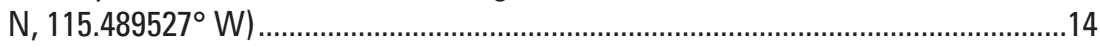

Stop 3.3. Ruby Wash Shorelines $\left(40.279339^{\circ} \mathrm{N}, 115.346147^{\circ} \mathrm{W}\right)$................................... 15

Stop 3.4. Franklin River Bridge $\left(40.531851^{\circ} \mathrm{N},-115.210585^{\circ} \mathrm{W}\right)$.................................... 16

Stop 3.5. Deep Gravel Quarry on CCC Road $\left(40.647220^{\circ} \mathrm{N}, 115.139360^{\circ} \mathrm{W}\right)$..................19

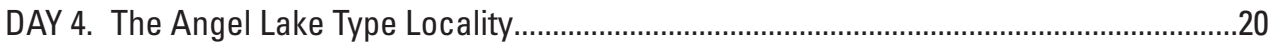

Stop 4.1. Angel Lake Right-Lateral Moraine $\left(41.025608^{\circ} \mathrm{N}, 115.077074^{\circ} \mathrm{W}\right)$..................20

Stop 4.2. Angel Lake and Recessional Moraine $3\left(41.026054^{\circ} \mathrm{N}, 115.085446^{\circ} \mathrm{W}\right)$.........24

Trip 2. Tectonics, Climate, and Paleogeomorphology of the Green River Formation.....................31

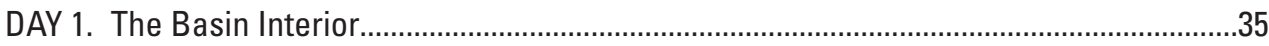

Stop 1. Middle Firehole Canyon Overview-Eocene Stratigraphy of the Greater Green River Basin

Stop 2. The "A-Bed" Arkosic Sandstone of the Wilkins Peak Member, Firehole Canyon .

Stop 3. The "D-Bed" Arkosic Sandstone of the Wilkins Peak Member, Firehole Canyon

Stop 4. Overview of the Underfilled to Balanced Filled Transition in the Basin Interior

Stop 5. Closer to the Aspen River Clastic Source-Alluvial Unit A in Sage Creek Canyon.

DAY 2. Basin Peripheral Green River Formation Strata Adjacent to the Uinta Uplift.............46

Stop 6. The Pipeline Section .................................................................................

Stop 7. The I-Bed Mound ....................................................................................

Stop 8. The Cathedral Bluffs Member of the Wasatch Formation..................................50

DAY 3. Syndeformational Green River Formation Adjacent to the Fold-Thrust Belt, Western GGRB.

Stop 9. Overview of White Mountain and the Basin Center, Rock Springs ..................50

Stop 10. Uplift on the Easternmost Thrust in the Middle Eocene, Round Mountain......52

Stop 11. Syndepositional Deformation on the Western Margin, Slate Creek.................53 


\section{Contents-Continued}

Trip 3. Modern, Holocene, and Pleistocene Lake Locales in the Western Great Basin, Nevada and California, June 21-25, 2015. . .61

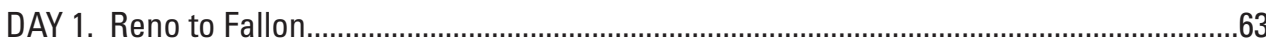

Stop 1-1. McCarren Ranch Gravel Pit (280119 E 4381620 N)...........................................63

Stop 1-2. Tracy exposure (285561 E 4382587 N) ……..............................................64

Stop 1-3. Big Soda Lake (337921 E 4376240 N) …………............................................65

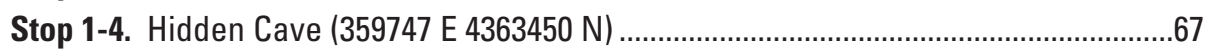

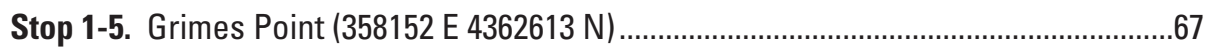

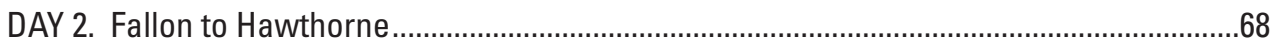

Stop 2-1. Salt Wells Beach Barrier (359233 E 4361079 N) ...............................................68

Stop 2-2. Bunejug Spit (359462 E 4359044 N) ...........................................................69

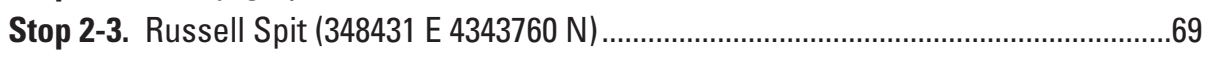

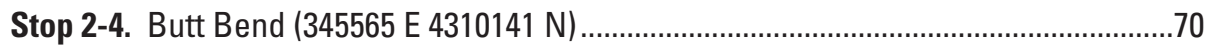

Stop 2-5. Walker Lake Holocene highstand (344382 E 4309386 N) ...............................70

Stop 2-6. Copper Canyon (346063 E 4289178 N) …………..........................................71

DAY 3. Hawthorne to Lee Vining ........................................................................................

Stop 3-1. County Park (311256 E 4209733 N) ............................................................

Stop 3-2. Grand Gash (311364 E 4210797 N) ............................................................74

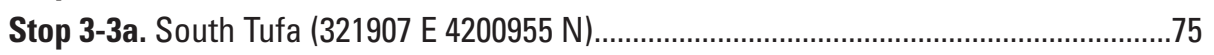

Stop 3-3b. Navy Beach (321907 E 4200955 N) ...............................................................

Stop 3-4. Panum Crater (320690 E 4199026 N) …………………………………........

DAY 4. Pleistocene Mono Basin ....................................................................................

Stop 4-1. Wilson Creek Type Section (313415 E 4210595 N) ……………………..........78

Stop 4-2. Mill Creek Cut (312854 E 4210969 N) ...............................................................

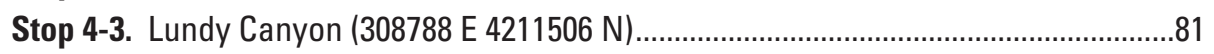

Stop 4-4. Bloody Canyon (311644 E 4195878 N) ...........................................................

DAY 5. Bodie State Historic Park and Washoe Lake.............................................................82

Stop 5-1. Bodie State Historic Park (323573 E 4231439 N) ...............................................82

Stop 5-2. Washoe Lake (259218 E 4351076 N)..........................................................83

Trip 4. Subalpine Lakes in An Active Volcanogenic Setting (Lassen Volcanic National Park, California) . .89

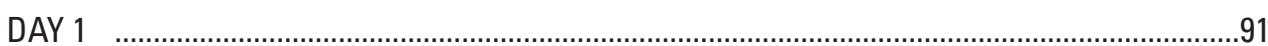

Stop 1. Brokeoff Mountain and Sulphur Works, HWY Mile 1 ........................................91

Stop 2. Bumpass Hell, HWY Mile 5.7 ................................................................................

Stop 3. Lassen Peak ............................................................................................

Stop 4. Chaos Crags/Chaos Jumbles ...........................................................................

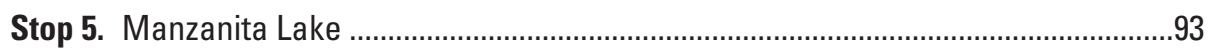

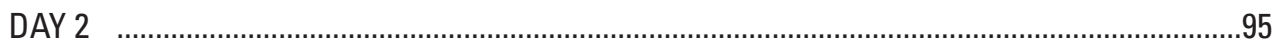

Stop 6. Butte Lake; HWY Mile 59.5 ..........................................................................95

Stop 7. Butte Creek Overlook...................................................................................96

Stop 8. Fantastic Lava Beds and Butte Lake Diatomite ................................................97

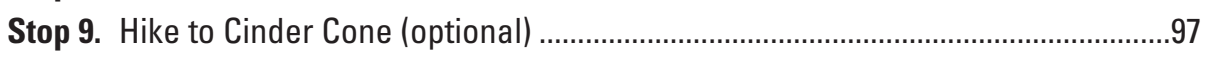




\title{
Trip 1.-New Investigations of Pleistocene Pluvial and Glacial Records from the Northeastern Great Basin
}

\author{
By Jeffrey S. Munroe', Benjamin J.C. Laabs ${ }^{2}$, Charles G. Oviatt ${ }^{3}$, and Paul W. Jewell ${ }^{4}$
}

\section{Trip Overview}

This field trip will provide an overview of the pluvial and glacial history of the northeastern Great Basin from the Last Glacial Maximum (LGM; MIS-2, about 22-18 ka BP) to the present. Several stops on this trip were included in a field trip planned for the Rocky Mountain Section meeting of the Geological Society of America in 2011 (Munroe and Laabs, 2011); parts of that field trip guide are reproduced here, with permission of the Geological Society of America.

Trip participants will stay three nights in Wendover, Nevada, which offers convenient access to geomorphic records of pluvial Lakes Bonneville and Franklin, as well as to the type locality for the LGM "Angel Lake" Glaciation (fig. 1.1). From Reno, we will drive east across Nevada on Interstate 80, reaching Wendover in the late afternoon. After checking into the hotel, we will make a short excursion to a well-developed abrasion platform produced by Lake Bonneville at the Provo shoreline. The second day will be spent visiting a variety of localities in the vicinity of Wendover featuring Bonneville and post-Bonneville sediments and landforms. During the third day, we will backtrack slightly to the west to visit Ruby Valley, which hosted pluvial Lake Franklin. We also will visit the Ruby Lake National Wildlife Refuge and hear from refuge staff about some of the issues involved in managing this resource. On the final day, we will visit Angel Lake at the northern end of the East Humboldt Mountains where LGM moraines are well preserved. We will discuss numerical modeling efforts focused on reconstructing glacial and pluvial climates, as well as records of post-glacial environmental change obtained from a sediment core from Angel Lake. We will return to Reno that afternoon, arriving late in the evening.

\section{Physiography}

Northeastern Nevada and western Utah are the heart of the Great Basin and feature classic Basin and Range topography. The relative lowland of the Bonneville Basin, formerly

\footnotetext{
${ }^{1}$ Geology Department, Middlebury College, Vermont.

${ }^{2}$ Department of Geological Sciences, SUNY-Geneseo, New York.

${ }^{3}$ Department of Geology, Kansas State University.

${ }^{4}$ Department of Geology and Geophysics, University of Utah.
}

inundated by pluvial Lake Bonneville, extends westward from the dramatic face of the Wasatch Front at Salt Lake City. The Bonneville Basin ends abruptly near the Utah-Nevada State line, where the landscape takes on an increasingly corrugated appearance with long, linear valleys separated by rugged north-south oriented mountain ranges. The highest mountains within the Great Basin, the Ruby-East Humboldt Range, extend for about $130 \mathrm{~km}$ to the southwest of Wells, Nevada, reaching a maximum elevation of 3,471 m at Ruby Dome. Many of the linear valleys contained pluvial lakes during the time when Lake Bonneville existed.

\section{Pluvial Lakes}

Despite the arid climate characterizing the Great Basin today, abundant evidence exists for large lakes occupying valley floors in the past. These "pluvial" lakes have been the target of considerable study dating back to the pioneering work of prominent geologists with the U.S. Geological Survey (USGS) (Russell, 1885; Gilbert, 1890). Features delimiting the former shorelines of these lakes are obvious in dozens of valleys (Mifflin and Wheat, 1979; Reheis, 1999). These features include beach berms, cuspate spits, and lagoons at high elevations, and featureless plains underlain by deepwater sediment at lower elevations. Mapping and dating of these landforms provides information about former episodes of lake transgression and regression. Many of these lakes were hydrologically closed (i.e. lacking surface hydrologic connections to other basins), and, thus, fluctuations in former lake levels are important signals of past climate variability.

Most work on pluvial lake records in the Western United States has focused on the two largest lakes_-Lakes Bonneville and Lahontan (fig. 1.1). At its maximum, Lake Bonneville covered about 50,000 $\mathrm{km}^{2}$ of western Utah and had a maximum depth of more than $300 \mathrm{~m}$ (Gilbert, 1890). Lake Lahontan inundated about 22,000 $\mathrm{km}^{2}$ of interconnected basins in western Nevada and had a maximum depth of about $280 \mathrm{~m}$ (Mifflin and Wheat, 1979). The pre-MIS-2 history of both lakes is less precisely known, but available evidence from one core in the Bonneville Basin (Oviatt and others, 1999) indicates that large lakes were present in these basins at times coincident with even-numbered MIS stages and volume maxima of Northern Hemisphere ice sheets (MIS stages 6,12,16), during the middle and late Quaternary. 


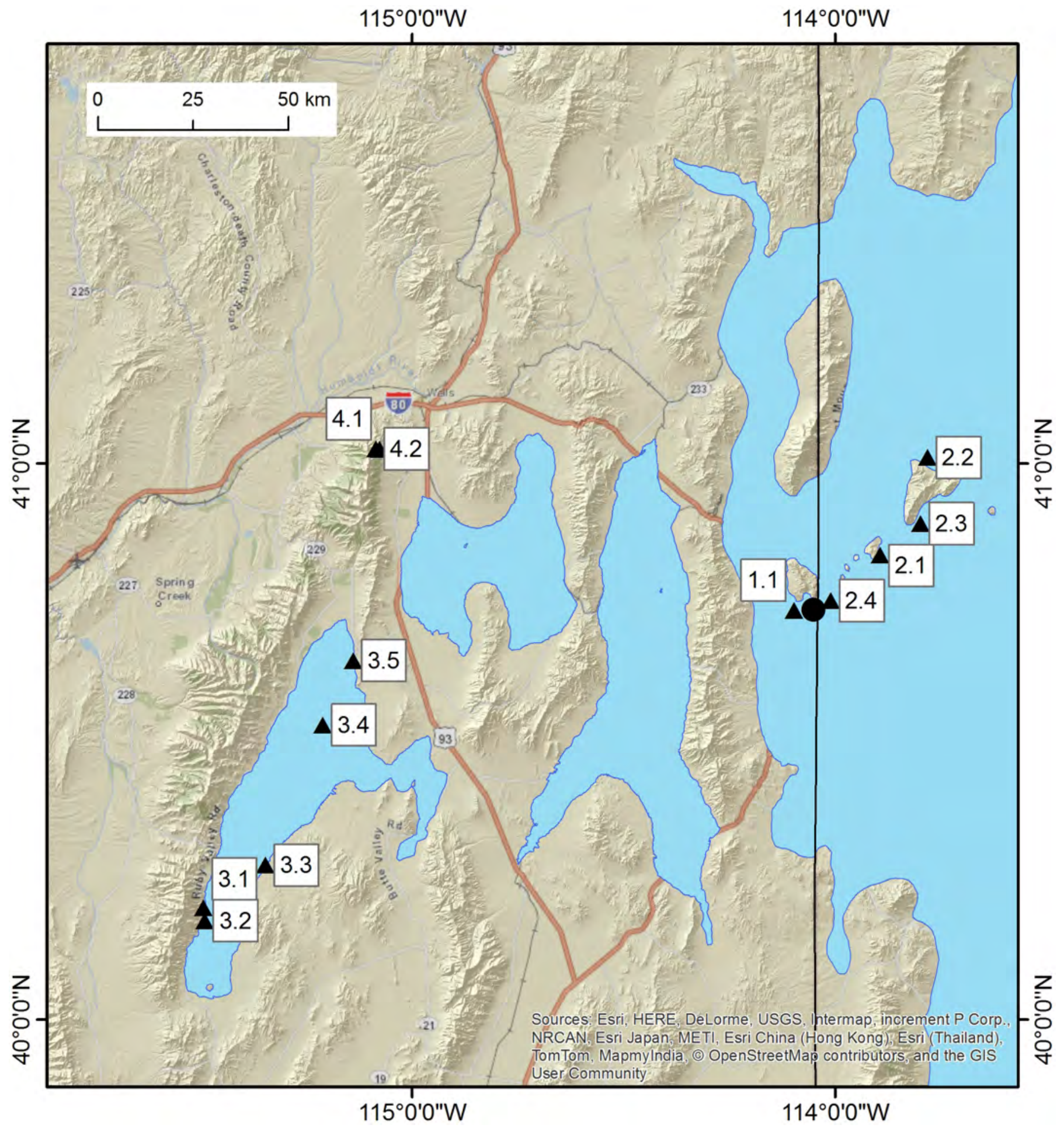

Figure 1.1. Route of the field trip with stops. 
In contrast, the MIS-2 deposits of these lakes are well preserved, and abundant evidence indicates that both lakes rose to roughly coincident highstands during MIS-2 (Benson and others, 2011; Oviatt, 2015). Regression continued throughout the latest Pleistocene, and the lakes were reduced to isolated playas and shallow, brackish ponds by the early Holocene (Oviatt and others, 2003).

Despite their fame, Lakes Bonneville and Lahontan were not the only pluvial lakes in the Great Basin. Dozens of smaller lakes existed in valleys from New Mexico northwestward to Oregon, but the records from these settings have received generally less attention (Mifflin and Wheat, 1979; Reheis, 1999; Reheis and others, 2014). Pluvial conditions within the Great Basin have long been considered a result of the southward deflection of prevailing storm tracks by the Laurentide Ice Sheet (Antevs, 1948). This mechanism, which has been broadly supported by numerical modeling (Bartlein and others, 1998), explains the general synchronicity between the global LGM and the rising pluvial lakes (Kutzbach, 1987). However, maximum highstands in many lake basins postdated the global LGM (Lyle and others, 2012; Munroe and Laabs, 2013b). The spatial pattern of highstand ages also is more complicated than would be expected if the prevailing storm track were simply deflected to the extreme southern end of the Great Basin before migrating back to the north during deglaciation (Munroe and Laabs, 2013b), and recent work has called into question the idea that the moisture supporting pluvial lakes was delivered from the Pacific (Lyle and others, 2012). Furthermore, many lake basins contain geomorphic evidence of stable water planes at elevations below the ultimate highstand, at least some of which were produced by transgressions that interrupted the overall decline of water level following the pluvial maximum (for example, Munroe and Laabs, 2013a). Little is known about whether these interruptions in the general desiccation of the pluvial lakes were synchronous between basins, or whether they were out of phase as a result of differences in hypsometry, local climate, etc. Overall, this temporal complexity of lake behavior across the Great Basin signifies important regional climatic variability during the last glacial-interglacial transition.

\section{Glacial Geomorphology}

Although glaciers are absent from the Great Basin today, the spectacular mountain landscapes, particularly of the Wasatch Mountains and Ruby-East Humboldt Ranges, testify to extensive Pleistocene glaciation. The glacial record at the western front of the Wasatch Mountains is especially well preserved, delimiting the termini of large west-flowing valley glaciers. The glacial geology and geomorphology have been mapped near the Wasatch Fault (for example, Richmond, 1964; Scott and Shroba, 1985; Personius and Scott, 1992), revealing evidence of ice advances during the Bull Lake (penultimate) and Pinedale (last) Glaciations (Richmond, 1964). Reconstructed ice extents for the Pinedale Glaciation reveal regionally low glacier equilibrium line altitudes in the Wasatch Mountains (Munroe and others, 2006; Laabs and others, 2011), ranging from about 2,370-2,650 m above sea level (asl) with a mean of 2,500 m asl. Cosmogenic beryllium-10 $\left({ }^{10} \mathrm{Be}\right)$ exposure ages of terminal moraines in the western Wasatch Mountains reveal that glacier maxima persisted until the early part of the Bonneville highstand and possibly for its duration (Laabs and others, 2011). These two observations support the idea that mountain glaciers responded to the same regional-scale climate changes that accompanied the Lake Bonneville highstand, and that the lake may have served as a local moisture source for glaciers down-wind (Munroe and Mickelson, 2002).

In the heart of the Great Basin, the Ruby-East Humboldt Mountains preserve the most dramatic glacial geomorphology between the Wasatch and Sierra Nevada Mountains (fig. 1.2). Blackwelder $(1931,1934)$ presented a short overview of the glacial geology of the Ruby Mountains. In colorful language, he described the “...wild crags of the freshly torn cirques” and noted that the glacial deposits represent two glaciations separated by a prolonged interval of weathering. He named these the Lamoille (older) and Angel Lake (younger) glaciations. Sharp (1938) expanded upon Blackwelder's work, formalized the Lamoille and Angel Lake designations, discussed controls over the extent of glaciation, and summarized mechanisms of post-glacial valley modification. Inventorying of glacial features supports reconstruction of former glaciers in the Ruby-East Humboldt Mountains. This work indicates that the Ruby-East Humboldt Mountains contained more than 130 glaciers during the Angel Lake Glaciation, which collectively covered more than $270 \mathrm{~km}^{2}$ (Laabs and Munroe, 2008). Reconstructed equilibrium line altitudes (ELAs) range from 2,350 to 3,000 m, with a mean of about 2,700 m. Equilibrium lines generally decreased in elevation from south to north, and 10 of the 15 glaciers with ELAs below 2,500 m were located on the western slope. Together, this pattern indicates prevailing moisture transport from the northwest during the Angel Lake Glaciation. 


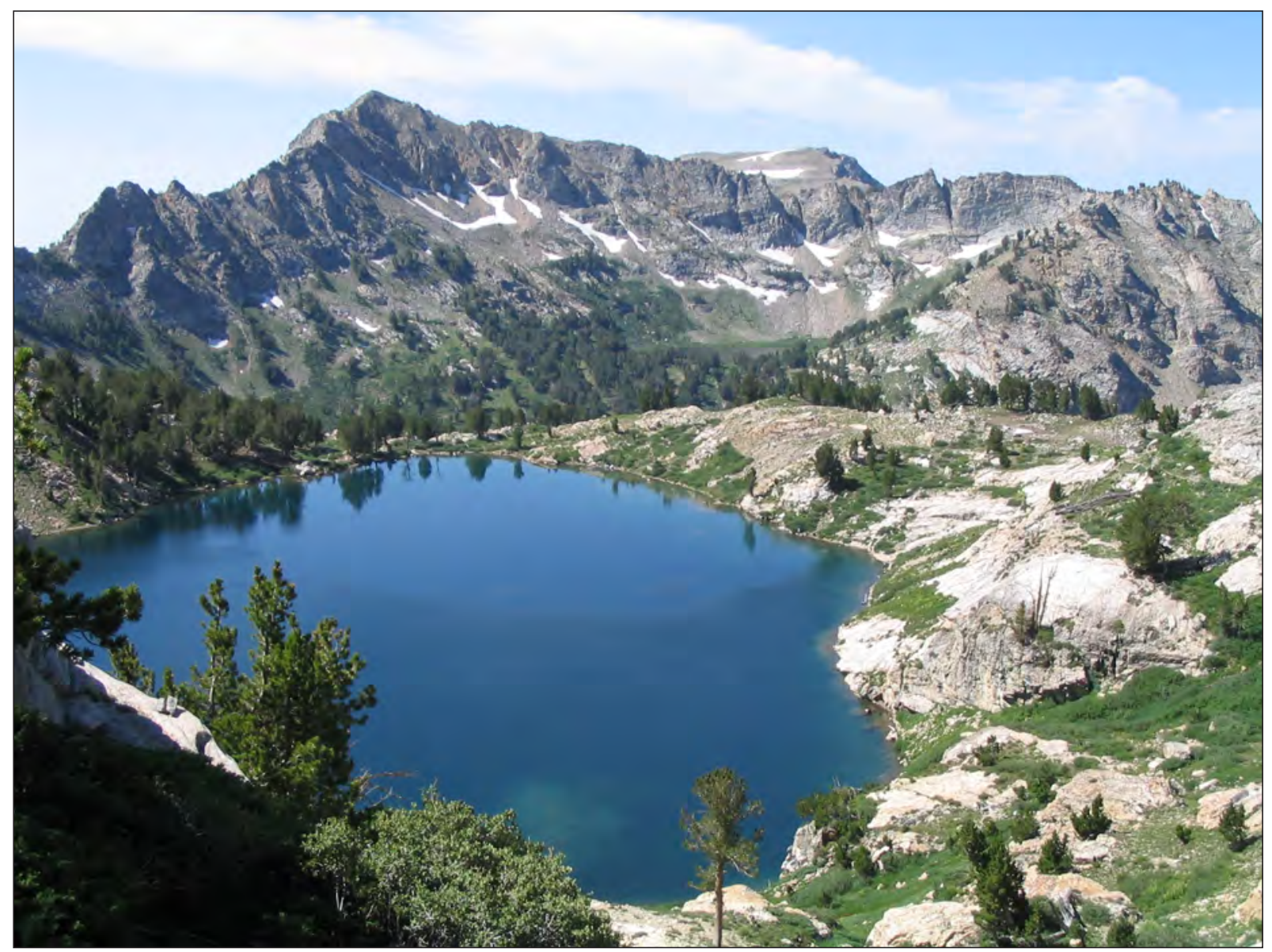

Figure 1.2. Photograph of alpine landscape in the Ruby Mountains. Liberty Lake is in the foreground. Photograph by Jeff Munroe, Middlebury College, July 29, 2006.

\section{DAY 1. Introduction to Lake Bonneville}

Total driving distance about $400 \mathrm{mi} / 650 \mathrm{~km})$

\section{Day 1 Overview}

After driving across Nevada on I-80, we will check into our hotel in Wendover before heading out for a single lateafternoon stop to introduce Lake Bonneville. Lake Bonneville was first studied systematically by Gilbert (1890), and has since been the subject of much scientific work. At this stop, we will review the late Quaternary history of Lake Bonneville, as well as the history of Bonneville research.

\section{Directions to Stop 1.1}

From the intersection of highways 58 (Wendover Blvd.) and 93A in Wendover, go west about $2.6 \mathrm{mi}(4 \mathrm{~km})$ on Wendover Blvd. out of town to the base of the rhyolite hill; park off the pavement, and walk to southeast about $0.6 \mathrm{mi}(1 \mathrm{~km})$ around the hill to the abrasion platform at the Provo shoreline. 
Stop 1.1. Rhyolite Hill, west of Wendover $\left(40.7372^{\circ}\right.$ $\mathrm{N}, 114.0971^{\circ} \mathrm{W}$ )

This is the first of five stops over 2 days focused on the Late Quaternary history of Lake Bonneville (figs. 1.3 and 1.4). Lake Bonneville continuously overflowed into the Snake River drainage basin in southern Idaho from about 18-15 cal ka, while the Provo shoreline developed. There is tufa plastered on the walls of the rhyolite hill below the Provo shoreline.
At this stop, we also can discuss Great Basin Quaternary history, and the regional and long-term contexts of Lake Bonneville and other Pleistocene lakes and glaciers in the Great Basin.

\section{Directions back to Wendover}

Retrace the route to return to Wendover and the hotel.

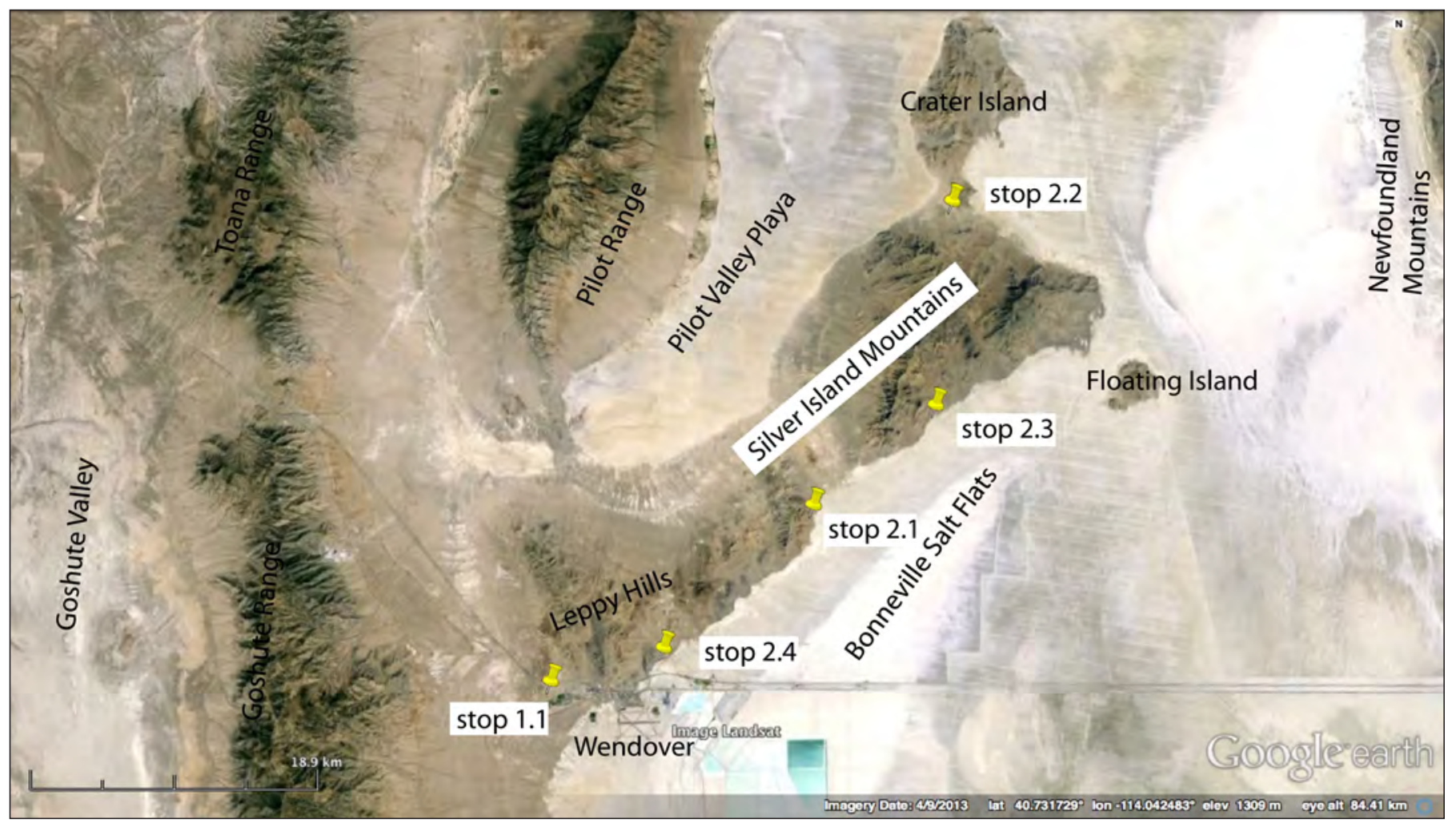

Figure 1.3. Google Earth ${ }^{\mathrm{TM}}$ image of the field trip area in the Bonneville basin. 


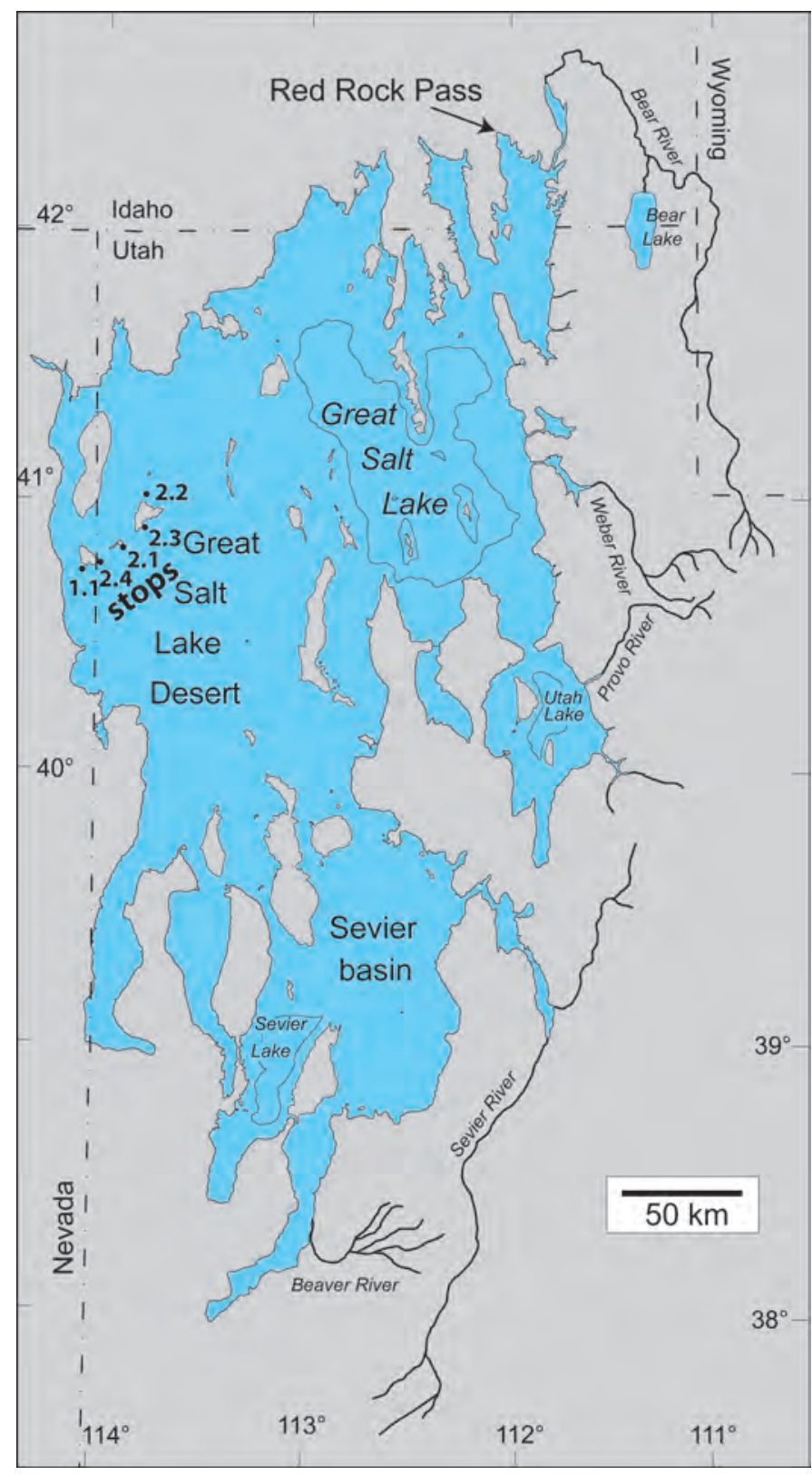

Figure 1.4. Map of Lake Bonneville; field trip stops marked along western of the main body of the lake (in the Great Salt Lake Desert).

\section{DAY 2. Pluvial Lake Bonneville}

\author{
(Total driving distance about $80 \mathrm{mi} / 129 \mathrm{~km}$ )
}

\section{Day 2 Overview}

Four stops on the second day of the trip will feature landforms and exposures of the stratigraphic sequence of Lake Bonneville (figs. 1.3 and 1.4), permitting discussion of the Bonneville lake-level chronology (fig. 1.5, table 1.1) and the relationship between the lake and glaciers in its basin. Important references to the geology and hydrology of this area include numerous geologic maps by Miller and colleagues (D.M. Miller, U.S. Geological Survey, oral and written commun., 1990-2015; Miller and Lush, 1981; Miller, 1990; Miller and Jordan, 1990), Lines (1979), Duffy and Al-Hassan (1988), Mason and Kipp (1989), Bowen and others (2014), Mayo and others (2014), and South and others (2014). References on tufa deposited in Lake Bonneville include Nelson and others (2005) and Felton and others (2006).

\section{Directions to Stop 2.1}

From Utah exit 4 on I-80 east of Wendover, drive on the paved Leppy Pass Road north to the intersection with the Bonneville Salt Flats road, which turns off to the east (the paved Bonneville Salt Flats road ends in a parking area in about $4 \mathrm{mi}[6 \mathrm{~km}]$, and from the parking area you can walk or drive out onto the salt flats). To go to field-trip stop 2.1, leave the pavement at the road intersection and drive about $0.75 \mathrm{mi}(1.2 \mathrm{~km})$ toward the northwest on the gravel road to the intersection with the Bureau of Land Management (BLM) Silver Island Mountains National Backcountry Byway, and turn toward the northeast. Stay on the Byway, which parallels the Silver Island Mountains, for about $7 \mathrm{mi}(11 \mathrm{~km})$ to the base of a quartzite hill; park off the Byway for stop 2.1.

\section{Stop 2.1. Quartzite Hill $\left(40.8363^{\circ} \mathrm{N}, 113.8933^{\circ} \mathrm{W}\right)$}

At this stop (figs. 1.3 and 1.4), we will hike up a hill of Prospect Mountain Quartzite (age, late Proterozoic to early Cambrian) to see tufa at the Stansbury and Provo shorelines. We will discuss the overall geologic history we can see as well as some of the issues regarding the Bonneville Salt Flats, associated mineral extraction activities, and land speed records that have been set on the salt flats. Be sure to take water and a camera, and be careful (the hill is steep, and there are lots of loose rocks). Have fun, and appreciate the views of the salt flats and everything else! 
Trip 1. New Investigations of Pleistocene Pluvial and Glacial Records from the Northeastern Great Basin

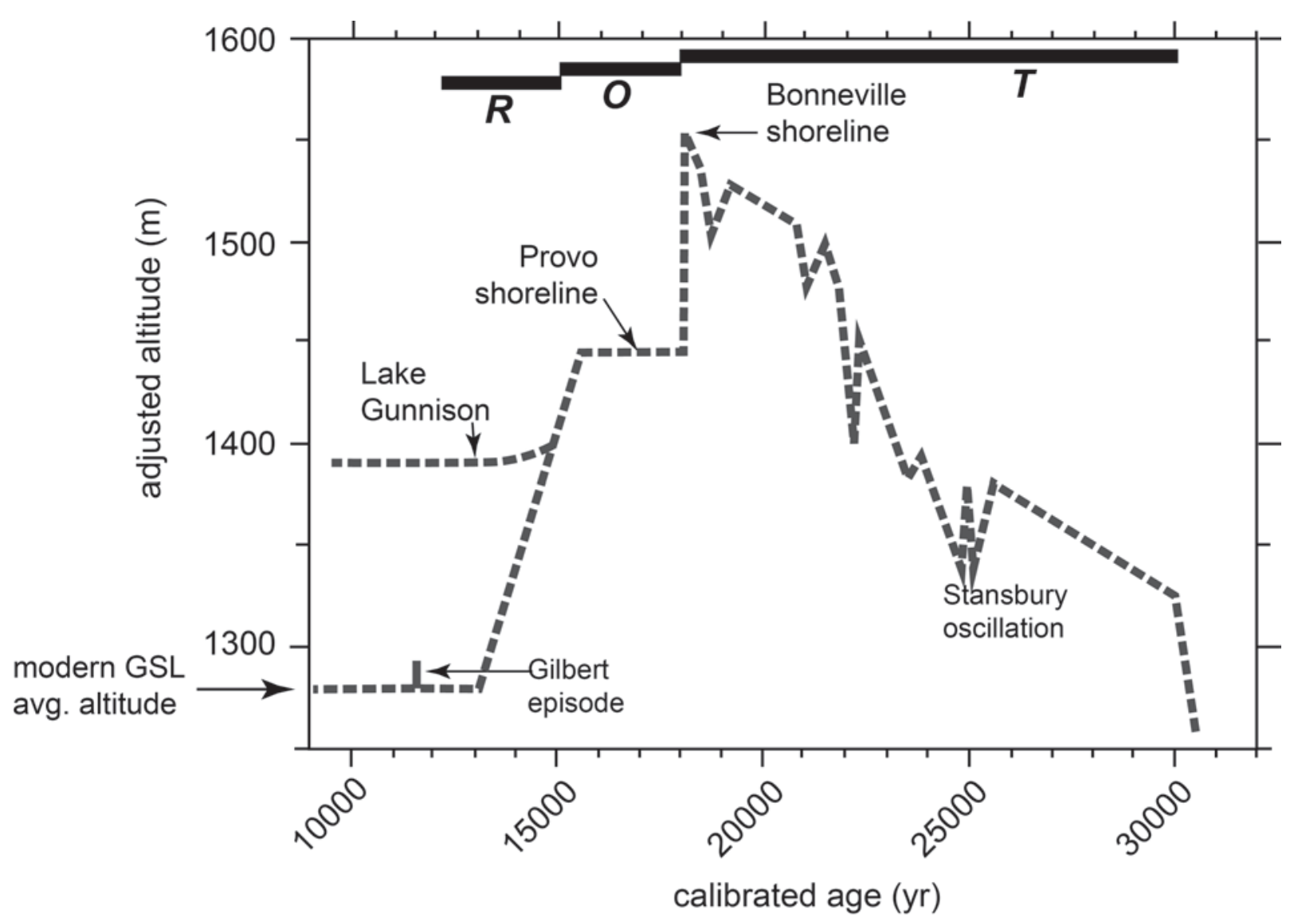

Figure 1.5. Chronology of Lake Bonneville modified from Oviatt (2015).

Table 1.1. Suggested ages for major events in Lake Bonneville history.

\begin{tabular}{lcc}
\hline \multicolumn{1}{c}{ Event } & $\begin{array}{c}\text { Radiocarbon age } \\
\left({ }^{14} \mathbf{C} \text { ka BP) }\right.\end{array}$ & $\begin{array}{c}\text { Calibrated age } \\
\text { (cal ka) }\end{array}$ \\
\hline Initial rise of Lake Bonneville & 26 & 30 \\
Stansbury shoreline & 21 & 25 \\
Bonneville shoreline & 15 & 18 \\
Provo shoreline & $15-12.5$ & $18-15$ \\
\hline
\end{tabular}

*These ages are rounded from estimates, and precise uncertainties are not available; reasonable uncertainties would be plus or minus several hundred calibrated years. Modified from Oviatt (2015, table 1). 


\section{Directions to Stop 2.2}

From stop 2.1, drive toward the northeast on the Byway for about $23 \mathrm{mi}$ (37 km), around the northeast corner of the Silver Island Mountains, to Donner-Reed Pass, between the Silver Island Mountains and Crater Island. The pass overlooks Pilot Valley Playa to the west. Park near the byway.

\section{Stop 2.2. Donner-Reed Pass $\left(41.0106^{\circ} \mathrm{N}\right.$, $\left.113.7814^{\circ} \mathrm{W}\right)$}

This stop, between the Silver Island Mountains and Crater Island, is a good place to see Pilot Valley Playa to the west, and to discuss the playa, Pilot Peak, the Donner party, and other topics (figs. 1.3 and 1.4). Pilot Playa has proven an excellent locality to understand interactions between subsurface freshwater inflow from the Pilot Mountains and the playa environment to the east (Duffy and Al-Hassan, 1988; ongoing studies by geologists from Brigham Young University, including Alan Mayo, John McBride, Steve Nelson, Kevin Rey, and Dave Tingey). Even today, water from the Pilot Mountains is the sole fresh water source for the town of Wendover. The Donner Party passed through this area and Pilot Peak became a prominent landmark for many of the western settlers who followed. This is a good place to eat lunch.

\section{Directions to Stop 2.3}

From stop 2.2, drive back to the southeast, then to the southwest, along the Byway for about $16 \mathrm{mi}(26 \mathrm{~km})$ and park along the road next to the gravel-capped outcrop of Lake Bonneville fine-grained deposits.

\section{Stop 2.3. “lozenge" stop $\left(40.8926^{\circ} \mathrm{N}, 113.7978^{\circ} \mathrm{W}\right)$}

At this stop, lacustrine gravel overlies fine-grained sediments of Lake Bonneville and pre-Bonneville oolitic sand. This is one of many lacustrine landforms mapped by Currey (1982) as part of the Gilbert shoreline. However, the lacustrine gravel at this site is roughly $5 \mathrm{~m}$ too high to have been deposited during the Gilbert episode (about $11.6 \mathrm{cal} \mathrm{ka}$ ). The altitude of the lacustrine gravel at stop 3 has not been precisely measured, but is about $1,300 \mathrm{~m}$; the highest altitude of known deposits of the Gilbert-episode lake is 1,295 m (or it may be several meters higher in geomorphically favorable localities; Oviatt, 2014). Whether or not the gravel (which has not been dated) is related to the Gilbert episode or to regressive-phase Bonneville is less important for our purposes than is the geomorphology at the site. We can observe here the effects of post-Bonneville denudation, probably caused by sheetwash and gully erosion combined with wind deflation. These processes have led to topographic accentuation and "lozenge" formation (fig. 1.6). The gravel is relatively resistant to erosion, so it forms a protective cap on the underlying finer-grained and lessresistant sediments.

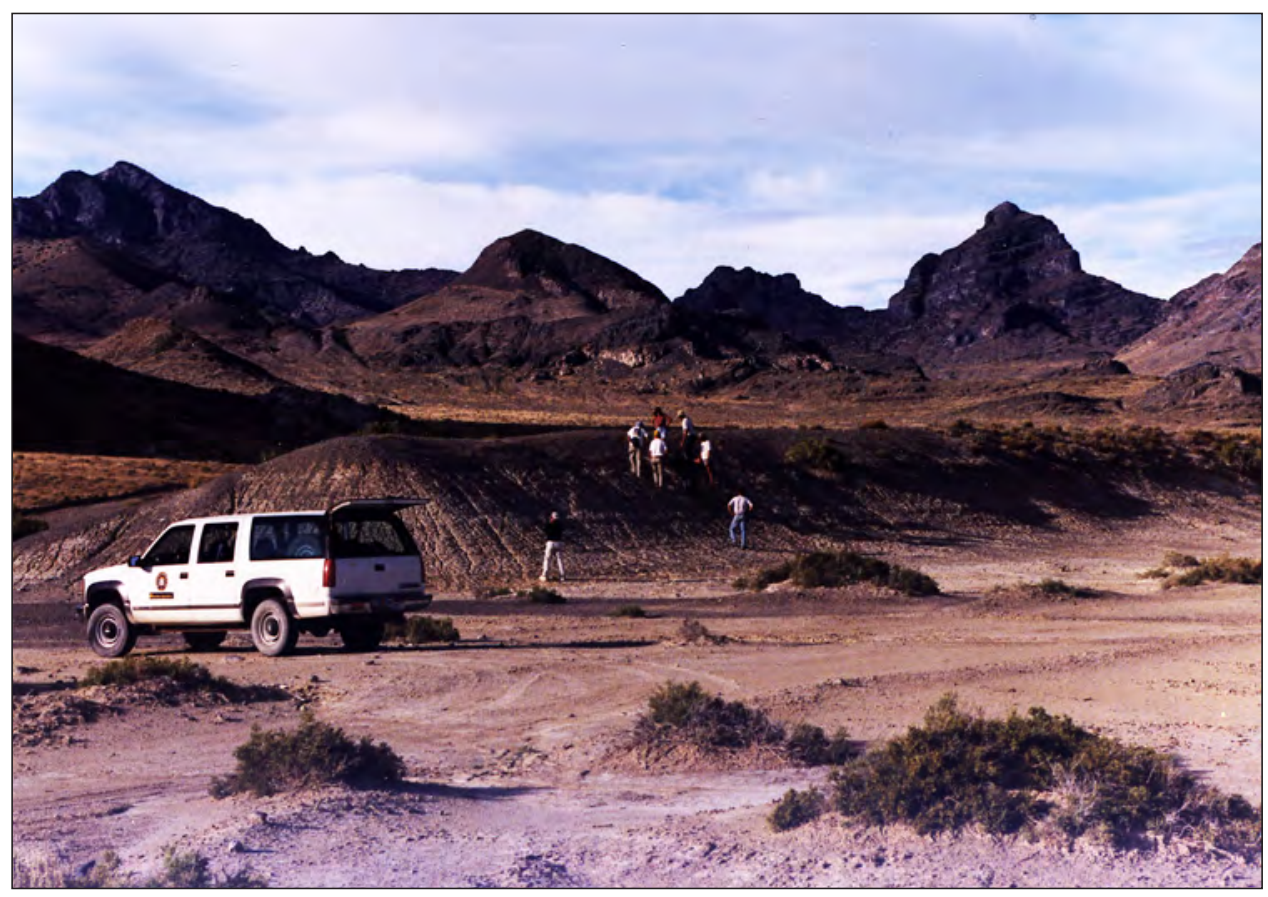

Figure 1.6. Photograph of "lozenge" at stop 2.3. Photograph by C.G. Oviatt, Kansas State University, 1998. 


\section{Directions to Stop 2.4}

From stop 2.3, drive to the southwest along the Byway, past stop 2.1, to the intersection with the Bonneville Salt Flats road. From here, drive $0.9 \mathrm{mi}(1.4 \mathrm{~km})$ south on the paved Leppy Pass road, then turn off to the west on a road that goes toward the Leppy Hills. Drive about $2.1 \mathrm{mi}(3.4 \mathrm{~km})$, then turn toward the southwest on a dirt road and drive about $0.4 \mathrm{mi}$ $(0.6 \mathrm{~km})$. Park next to the dirt road and walk about $0.1 \mathrm{mi}$ $(0.16 \mathrm{~km})$ to the southeast to the open trench at stop 2.4 .

\section{Stop 2.4. Trackhoe trench at Jukebox Cave $\left(40.754915^{\circ} \mathrm{N}, 114.010204^{\circ} \mathrm{W}\right)$}

At this stop, we can see an excellent exposure in deposits of pre-Bonneville, Lake Bonneville, and post-Bonneville age (fig. 1.7). The section is as follows: (1) starting at the stratigraphic base, pre-Bonneville oolitic sand and carbonatecemented gravel and sand; (2) Lake Bonneville offshore fine-grained sediments (marl); (3) an unconformity that cuts the Bonneville section; (4) a gravel lens at the base of the post-Bonneville sequence (the gravel may have been deposited during the Gilbert episode, which culminated at about the altitude of the gravel in the Jukebox trench, about $11.6 \mathrm{cal} \mathrm{ka);}$ (5) wetland deposits of Holocene age, with radiocarbon ages and the Mazama ash. See the composite photograph of the north wall of the trench (fig. 1.7; table 1.2).

The trench was first opened in the mid-1980s as part of an archaeological investigation of Jukebox and Danger caves (Murchison, 1989). The spring and wetland that existed here, from the end of Bonneville time to as recently as a few decades ago, probably were used by prehistoric people for food resources and freshwater. Jukebox and Danger Caves (in the carbonate rocks in the hills west of the trench) are wellknown archaeological sites (Jennings, 1957; Rhode and others, 2006). In 2009, Jeff Pigati (USGS) and Jack Oviatt (Kansas State University) reopened the trench to make new exposures. The trench is cut into the toe of the piedmont alluvial fans, where the fan gravels interfinger with sediments of Lake Bonneville and post-Bonneville wetland deposits.

\section{Directions back to Wendover}

From stop 2.4, drive back to the paved Leppy Pass road, turn south to exit 4 on I-80, and go west back to Wendover and the hotel.

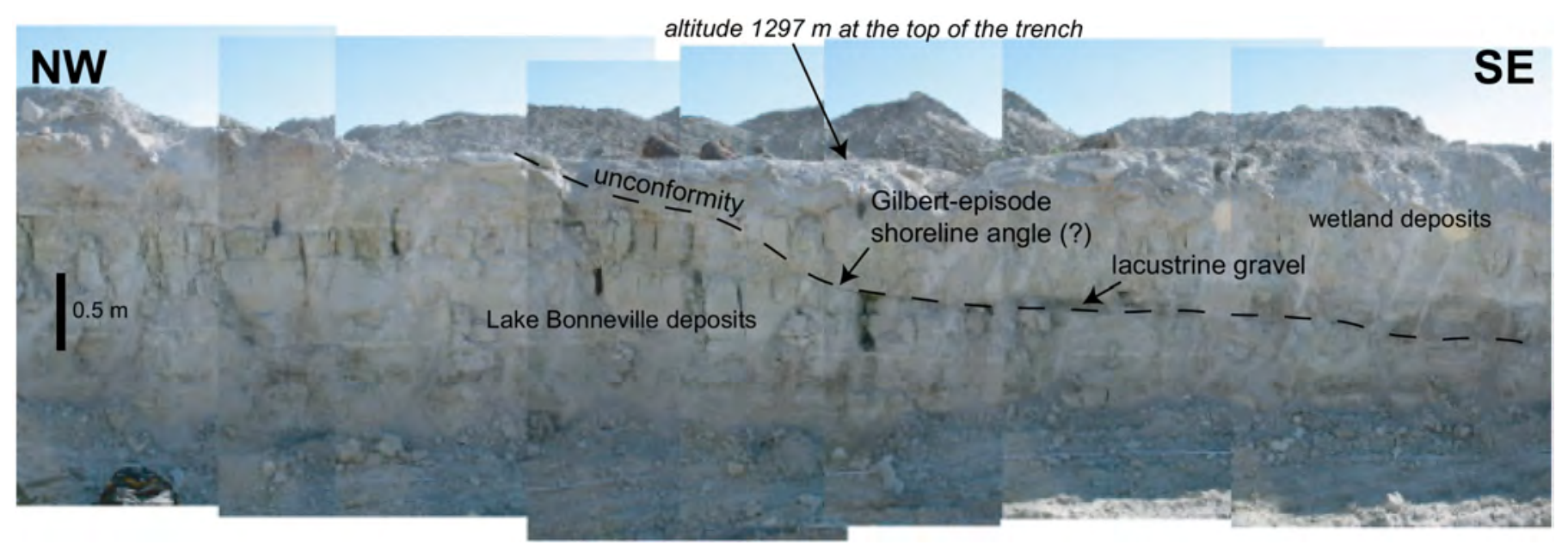

Figure 1.7. Composite photograph of the north wall of the Jukebox trench; stop 2.4 (see fig. 10, Oviatt, 2014).

Table 1.2. Radiocarbon ages from Jukebox trench.

\begin{tabular}{clll}
\hline $\begin{array}{c}\text { Radiocarbon } \\
\text { age }\end{array}$ & Laboratory & \multicolumn{1}{c}{ Material } & \multicolumn{1}{c}{ Reference } \\
\hline $9,450 \pm 150$ & Beta-21807 & “organic mud” & Murchison, 1989 \\
$8,360 \pm 140$ & Beta-18804 & "peaty layer” & Murchison, 1989 \\
$24,300 \pm 270$ & Beta-21808 & spring snails & Currey, pers. comm. \\
$6,730 \pm 40$ & Multiple ages & Mazama ash & Zdanowicz and others, 1999 \\
too young & 2 or 3 ages & organics & Pigati, USGS, oral commun., 2010 \\
\hline
\end{tabular}




\section{DAY 3. Pluvial Lake Franklin}

\section{(Total driving distance about $300 \mathrm{mi} / 480 \mathrm{~km}$ )}

\section{Day 3 Overview}

Day 3 focuses on the record of pluvial Lake Franklin on the east side of the Ruby-East Humboldt Mountains (figs. 1.1 and 1.8). We will visit several sites illustrating aspects of the last highstand and regression of this lake, and will receive an overview of the Ruby Lake National Wildlife Refuge (fig. 1.9) from refuge staff.

\section{Directions to Stop 3.1}

From Wendover, head west on I-80 for $86 \mathrm{mi}$, then exit on US 93 at Wells. Turn left to head south on US-93 (The Great Basin Highway). The road passes over a gentle divide before descending gently into the basin that was occupied by pluvial Lake Clover (Munroe and Laabs, 2011). At the low point of the basin, the road passes the western end of the Snow Water Lake playa. An obvious set of dunes rises about $10 \mathrm{~m}$ above the playa surface (fig. 1.10). Luminescence ages (single aliquot regeneration-optically stimulated luminescence [SAR-OSL]) on quartz grains from these dunes are approximately 100 years old, suggesting that the dunes (at least in their modern form) are recent features (J.S. Munroe, Middlebury College, unpub. data, 2014). At the intersection with NV-229 turn right to cross over the divide into the Ruby Valley. Follow NV-229 across the northern end of the Ruby Valley, before turning southward and paralleling the Ruby Mountain front. Note that the road transitions to a dirt surface that is well-maintained, but may not be appropriate for passenger vehicles in certain conditions. Near the southern end of the valley, the road passes the Gallagher State Fish Hatchery before reaching the headquarters of the Ruby Lake National Wildlife Refuge on the right. Park in the lot in front of the refuge headquarters.

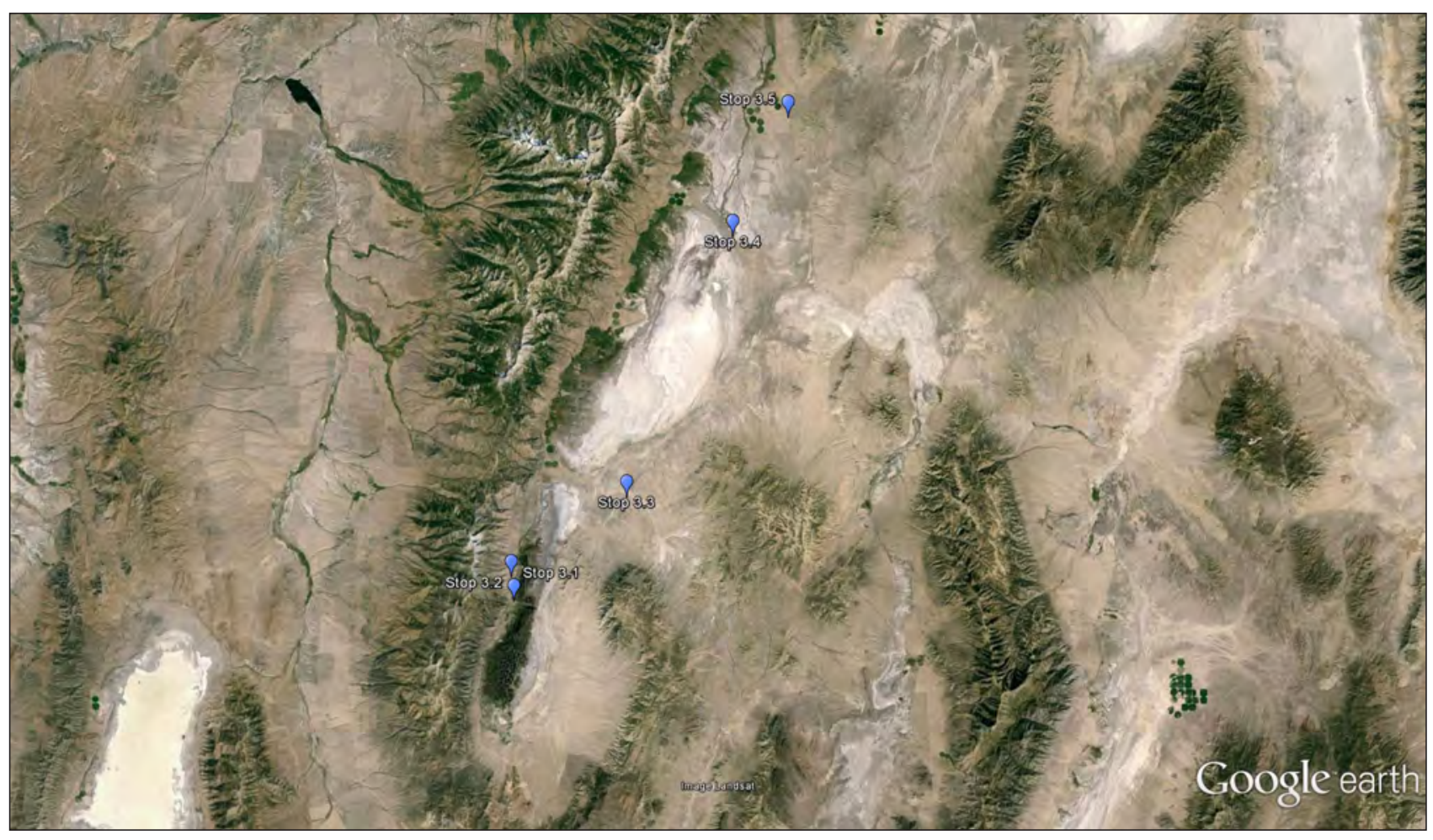

Figure 1.8. Google Earth ${ }^{\mathrm{TM}}$ image of the Franklin Valley showing stops on Day 3. 


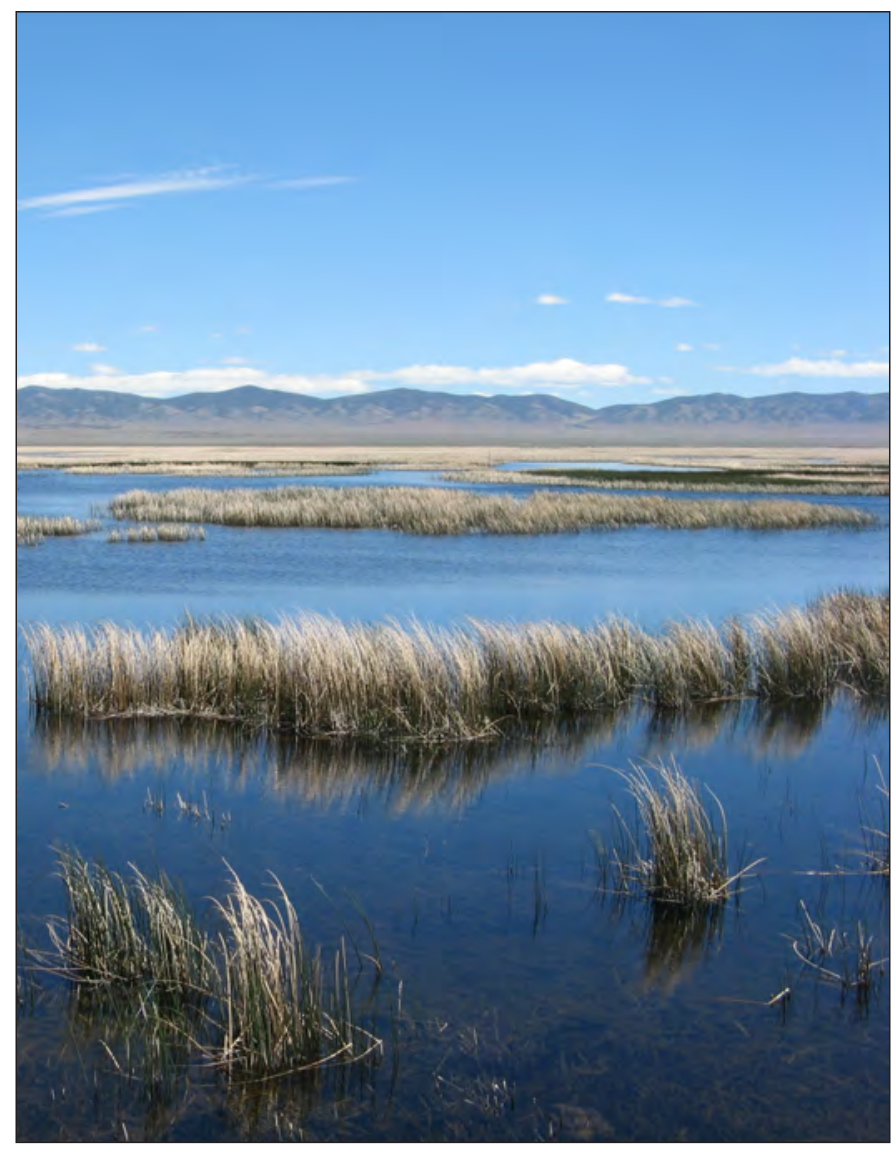

Figure 1.9. Photograph of the Ruby Marshes. Photograph by Jeff Munroe, Middlebury College, June $5,2010$.

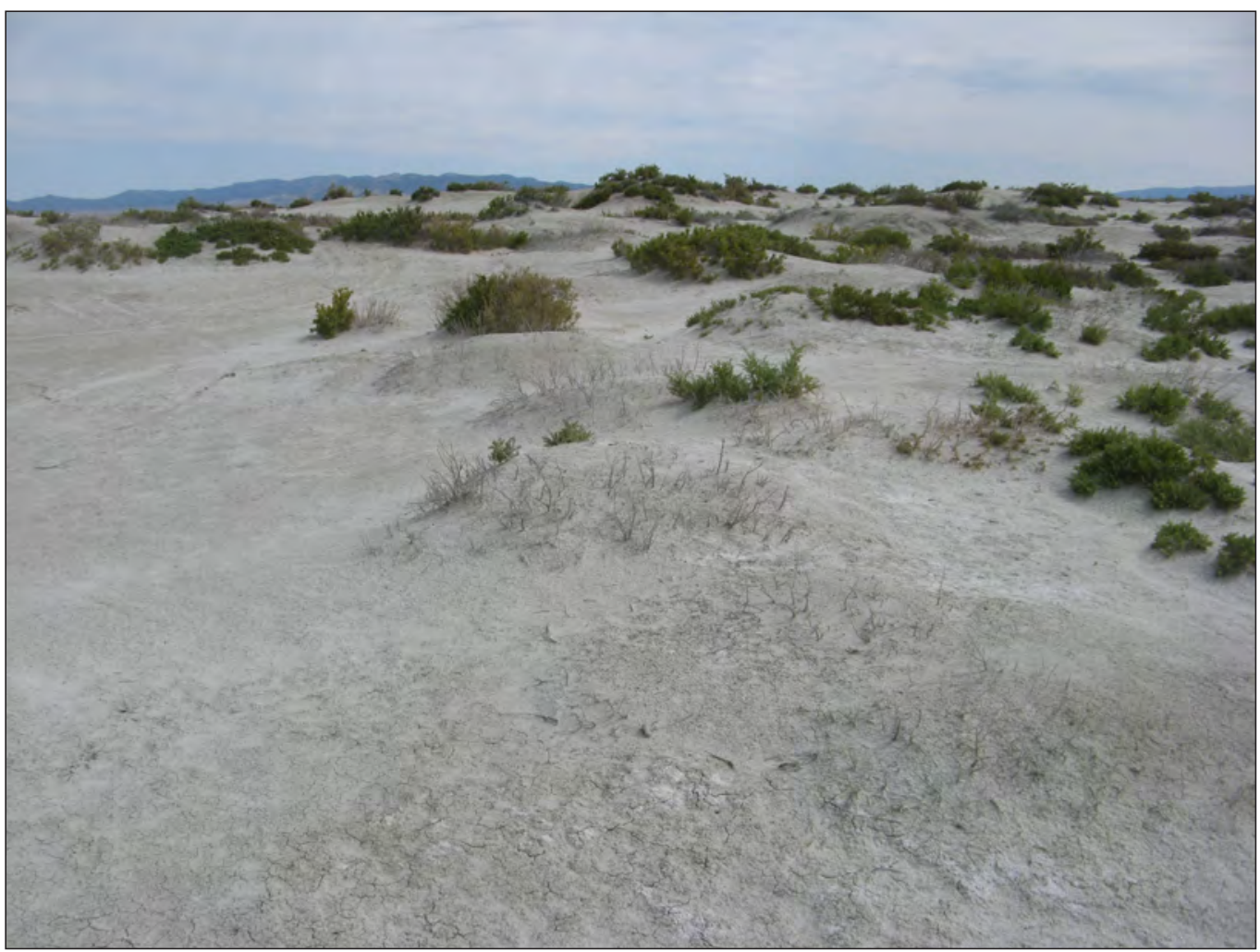

Figure 1.10. Photograph of the Snow Water Dunes. Photograph by Jeff Munroe, Middlebury College, July 27, 2014. 


\section{Stop 3.1. Ruby Lake National Wildlife Refuge and Pluvial Lake Franklin $\left(40.202050^{\circ} \mathrm{N}, 115.492771^{\circ} \mathrm{W}\right)$}

The Ruby Lake National Wildlife Refuge (RLNWR) was established in 1938 because of its critical location at the crossroads of several major corridors for migrating birds. Today the refuge covers about 40,000 acres, almost one-half of which is wetlands of the Ruby Marshes. More than 200 natural springs at the base of the Ruby Mountains deliver water to the marshes, and the refuge staff manages water levels within different sections of the marsh with a system of dikes, pumps, and canals. A self-guided auto tour passes through the marshes along several of these dikes, providing abundant opportunities for birdwatching. Maps of the auto-tour route are available at the refuge headquarters. The nearby Gallagher State Fish Hatchery also takes advantage of the water from the springs. The hatchery, which was built in 1940 and substantially updated in the late 1960s, primarily raises trout that are stocked in lakes and streams around northern Nevada.

The RLNWR occupies a valley that formerly held pluvial Lake Franklin, one of the largest pluvial lakes in the Great Basin after Bonneville and Lahontan (Mifflin and Wheat, 1979). At its highest level (about 1,853 m), Lake Franklin inundated the RLNWR with more than $35 \mathrm{~m}$ of water, covered more than $1,000 \mathrm{~km}^{2}$, and extended northward through the Franklin Valley, eastward across Dry Lake Flat, and into the North Butte Valley (fig. 1.11). All that is left of Lake Franklin today is the shallow Ruby Marshes and an ephemeral lake on the floor of Franklin Valley.

Unlike most of the smaller pluvial lakes in the Great Basin, the record of Lake Franklin has received considerable attention. Shoreline features recording a highstand of Lake
Franklin were noted by the earliest geological explorations in the area (Simpson, 1876), and later expeditions realized that these features reflected a lake confined to the Franklin Valley (Russell, 1885; Gilbert, 1890). Several decades later, the name Lake Franklin was assigned to this pluvial lake, taken from the modern ephemeral lake north of the Ruby Marshes (Sharp, 1938). In the early 1990s, lacustrine sediment cores from the vicinity of the Ruby Marshes were studied to reconstruct past water-level changes (Thompson, 1992). By comparing the relative abundance of different aquatic palynomorphs, Thompson (1992) was able to reconstruct how salinity of the marshes had changed over time, which was considered a signal of water depth. Lillquist (1994) mapped shorelines within the area flooded by Lake Franklin, and was able to assign ages to many of these features through radiocarbon dating of shell fragments retrieved from natural exposures and artificial excavations. Lillquist (1994) also recognized shorelines created by Lake Franklin at elevations below the highstand, and constructed a hydrograph charting several cycles of lake regression and transgression during the overall desiccation of the lake from MIS-2 into the Holocene. Most recently, Munroe and Laabs (2013a) augmented the dataset of Lillquist (1994) with additional radiocarbon ages and revised the Lake Franklin hydrograph. Stops during Day 3 will visit many of the shorelines whose ages have been constrained by radiocarbon dating.

\section{Directions to Stop 3.2}

Continue south from the refuge headquarters past the Gallagher State Fish Hatchery and turn left on (gravel) Brown Dike road. Park on the right and walk a short distance down into the RLNWR gravel pit for Stop 3.2. 


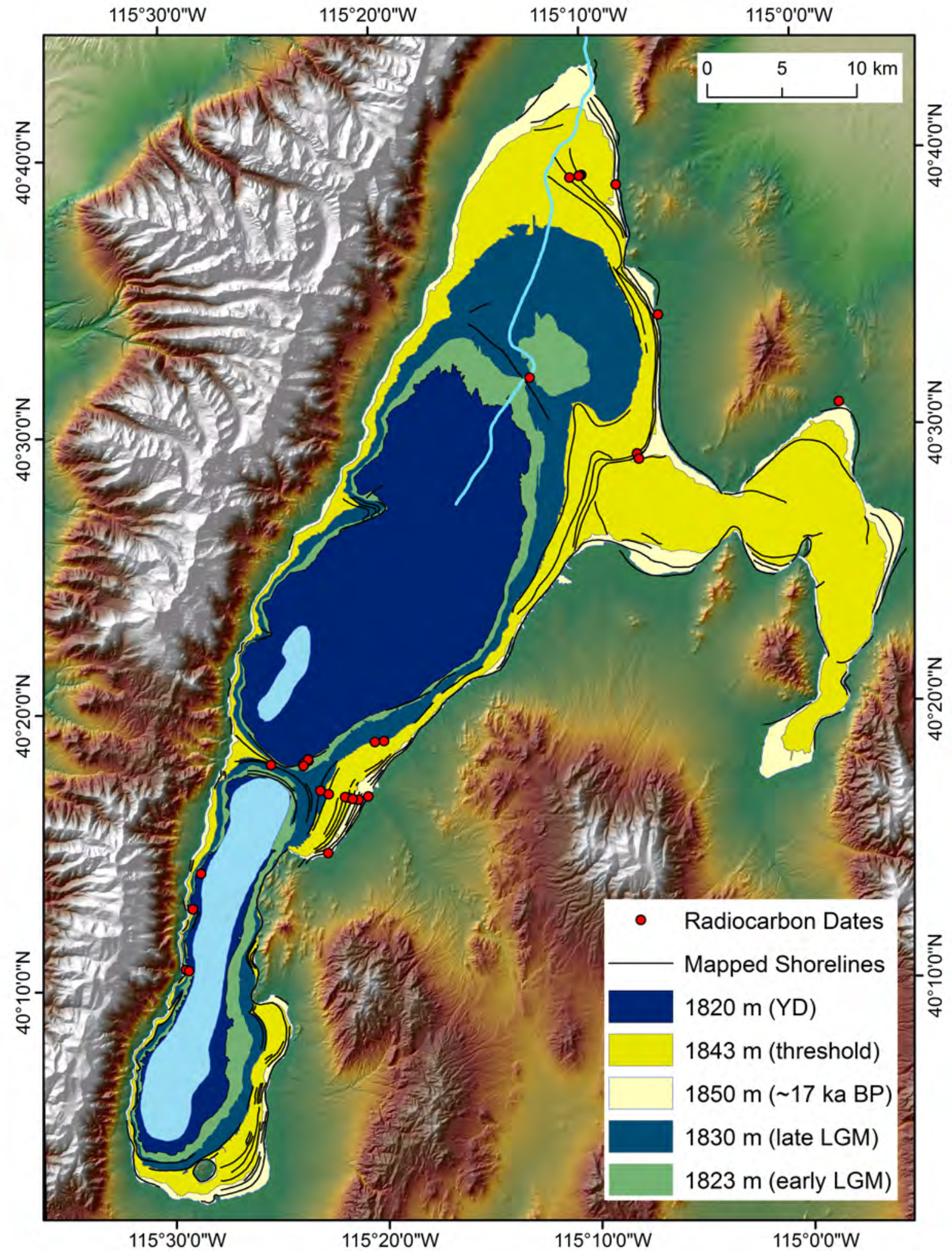

Figure 1.11. Map of the Lake Franklin region with outlines of the lake at five different elevations (in meters). Red circles mark locations where shoreline features are constrained by radiocarbon dates. From Munroe and Laabs, 2013a. 


\section{Stop 3.2. Ruby Lake National Wildlife Refuge Gravel Pit $\left(40.178605^{\circ} \mathrm{N}, 115.489527^{\circ} \mathrm{W}\right)$}

The excavation at this stop was a source of fill used in creating roads and dikes within the RLNWR. Please note that the pit is not open to the public. Visitors wishing to view the sediment exposed at this location should check with RLNWR staff at the refuge headquarters before entering the pit. The pit is located within a compound spit formed by transport of sediment by waves and currents when Lake Franklin stood at the 1,830-m level, about $23 \mathrm{~m}$ below the highstand elevation (fig. 1.11). The spit projects east-northeast from the mountain front, and is bordered to the southwest by a large alluvial fan draining off the southern Ruby Mountains. Lillquist (1994) inferred that the fan served as a major source of sediment for the spit, and concluded that northward sediment transport was dominant, with a minor component of transport to the south and east.

The north wall of the quarry exposes approximately $4 \mathrm{~m}$ of well-rounded, crudely stratified, locally imbricated gravel and coarse sand (fig. 1.12). The sediment is moderately well indurated, and locally is abundantly fossiliferous. Lillquist (1994) interpreted these sediments as a series of lagoon and foreshore/beach units, with the lagoons represented by marly silty sands, and the beaches by marly sandy gravels. A total of 10 radiocarbon ages are available from this location; five from beach facies, and five from lagoonal facies (Munroe and Laabs, 2013a). The beach samples are from the northern wall of the exposure. All five are in stratigraphic order, ranging from $14.2 \mathrm{ka} \mathrm{BP}$ at the top to $16.8 \mathrm{ka} \mathrm{BP}$ at a depth of about $300 \mathrm{~cm}$ (fig. 1.12). The other five radiocarbon ages are from lagoons that existed on the landward side of the spit, although the exact location of these relative to the modern exposure is unclear. These ages are generally consistent with those from the beach gravels (Munroe and Laabs, 2013a).

\section{Directions to Stop 3.3}

Turn vehicles around, return to Ruby Valley Road, and head back to the north (right) to exit the refuge. One-quarter mi past the intersection with the Harrison Pass Road on the left, turn right on the CCC Road. This dirt road leads along the crest of a narrow ridge that separated Lakes Franklin and Ruby when the water level declined below about 1,830 m. At the eastern end of this ridge, veer right and then left to ascend the distal slope of the Ruby Wash fan. The road bisects numerous beach ridges at near-right angles. The highest ridge is reached at an elevation of 1,850 $\mathrm{m}$ at an obvious "T" intersection. Use this space to turn around and park.

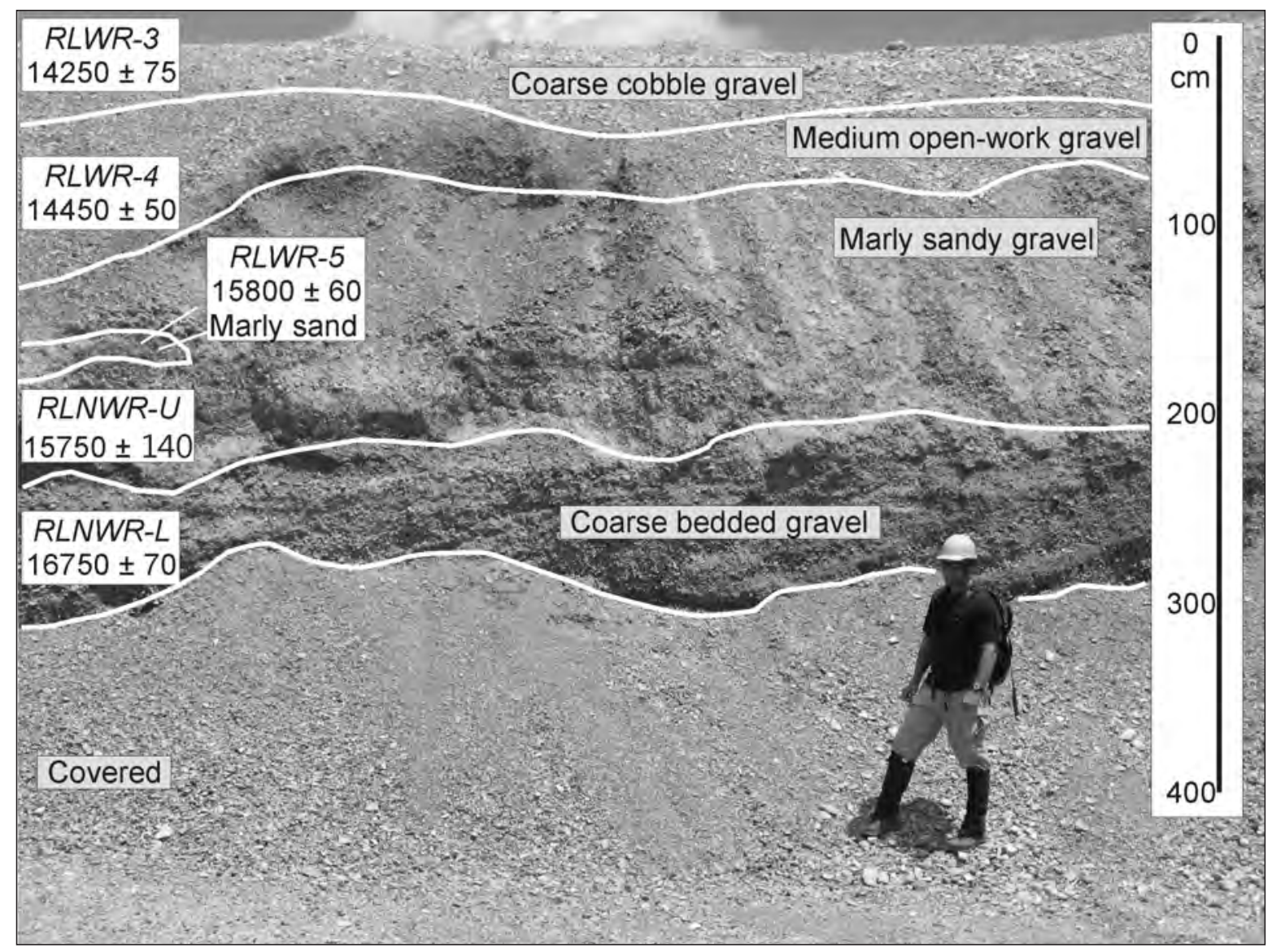

Figure 1.12. Photograph of exposure in the north wall of the Ruby Lake National Wildlife Refuge gravel quarry in June, 2010. The face stands approximately $4 \mathrm{~m}$ high and exposes cross-bedded, indurated, coarse gravelly sand interpreted as a beach environment. From Munroe and Laabs, 2013a. 


\section{Stop 3.3. Ruby Wash Shorelines $\left(40.279339^{\circ} \mathrm{N}\right.$, $\left.115.346147^{\circ} \mathrm{W}\right)$}

The road ascending Ruby Wash provides access to the most complete collection of well-expressed shoreline ridges in Ruby Valley (fig. 1.13). The highstand shoreline is obvious here at an elevation of 1,850 $\mathrm{m}$, and prominent shorelines are preserved down to an elevation of about $1,820 \mathrm{~m}$. There are few natural exposures in these features; however, Lillquist (1994) and Munroe and Laabs (2013a) excavated pits in the crests of many of the ridges. Radiocarbon dating of gastropod fossils sieved from beach gravels and well-sorted sands interpreted as nearshore deposits provide constraints on water-level fluctuations of Lake Franklin. A sample from the beach facies in the highstand ridge returned an age of $16.8 \mathrm{ka}$ $\mathrm{BP}$, and ages generally decrease with elevation to the lowest shorelines, which formed about 13 ka BP (Munroe and Laabs, 2013a). Within this overall regression, there is evidence for at least two transgressions, one which reached back to the highstand level ca. 16.0 ka BP, and another more modest transgression ca. $13.5 \mathrm{ka} \mathrm{BP}$ (fig. 1.14).

\section{Directions to Stop 3.4}

Descend past the shorelines to the intersection, and turn right to head north on the CCC Road. The road follows the 1,830-m shoreline around the distal end of the Ruby Wash fan; the lower 1,820-m shoreline is visible off to the west (left). The road then rises up to the higher shorelines at 1,843 and $1,850 \mathrm{~m}$ and curves back around to the north. Continuing around the western side of the Dry Lake Flat, the road follows a compound ridge with a crest elevation between 1,843 and 1,846 m. After passing Murphy Well, watch for a sign marking the road to Franklin River Bridge on the left. Take this turn and follow $6 \mathrm{mi}$ to the site of the former bridge (now impassable). Park along the road on the east side of the bridge for Stop 3.4.

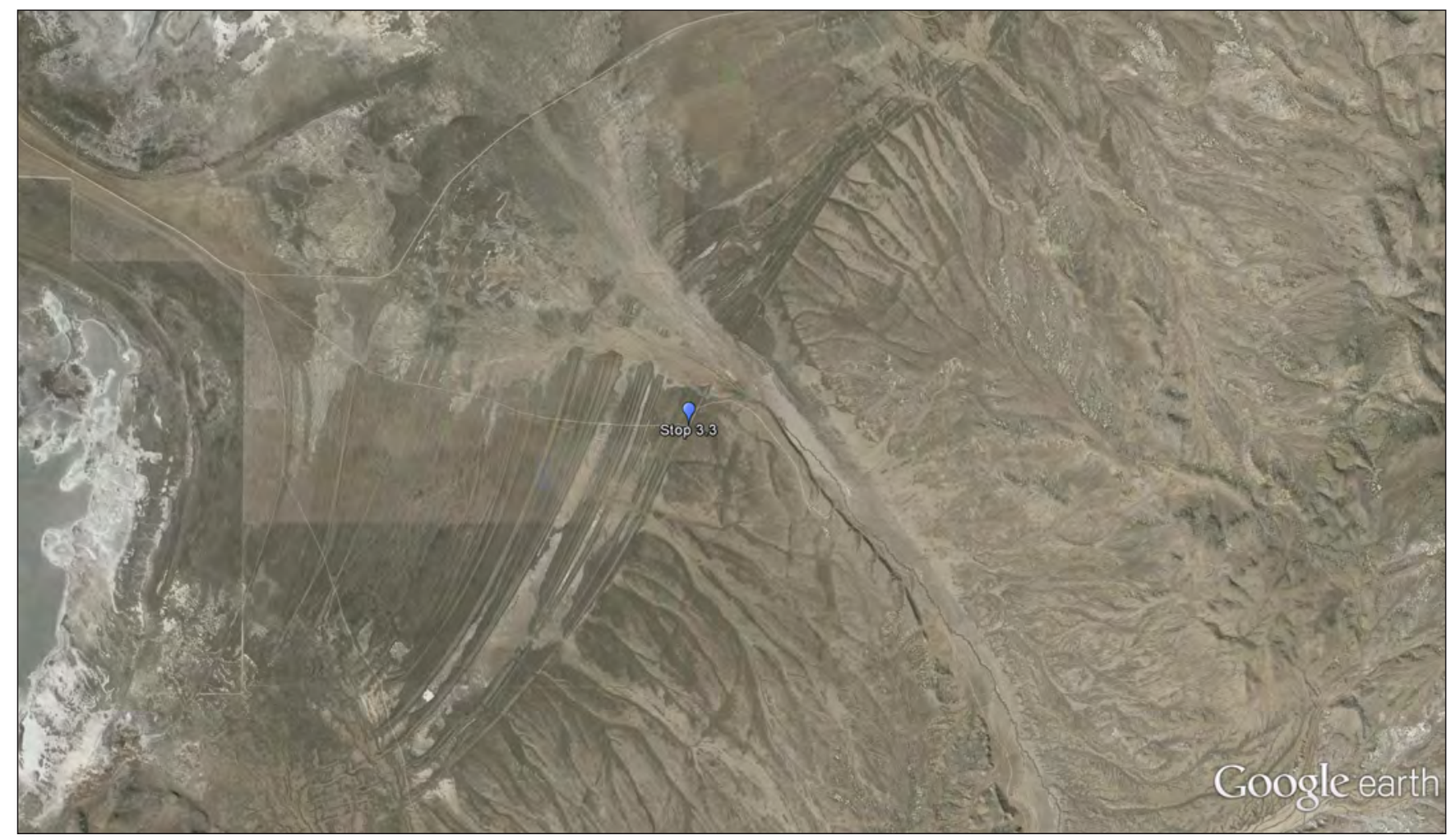

Figure 1.13. Google Earth ${ }^{\mathrm{TM}}$ image of the Ruby Wash shorelines. 


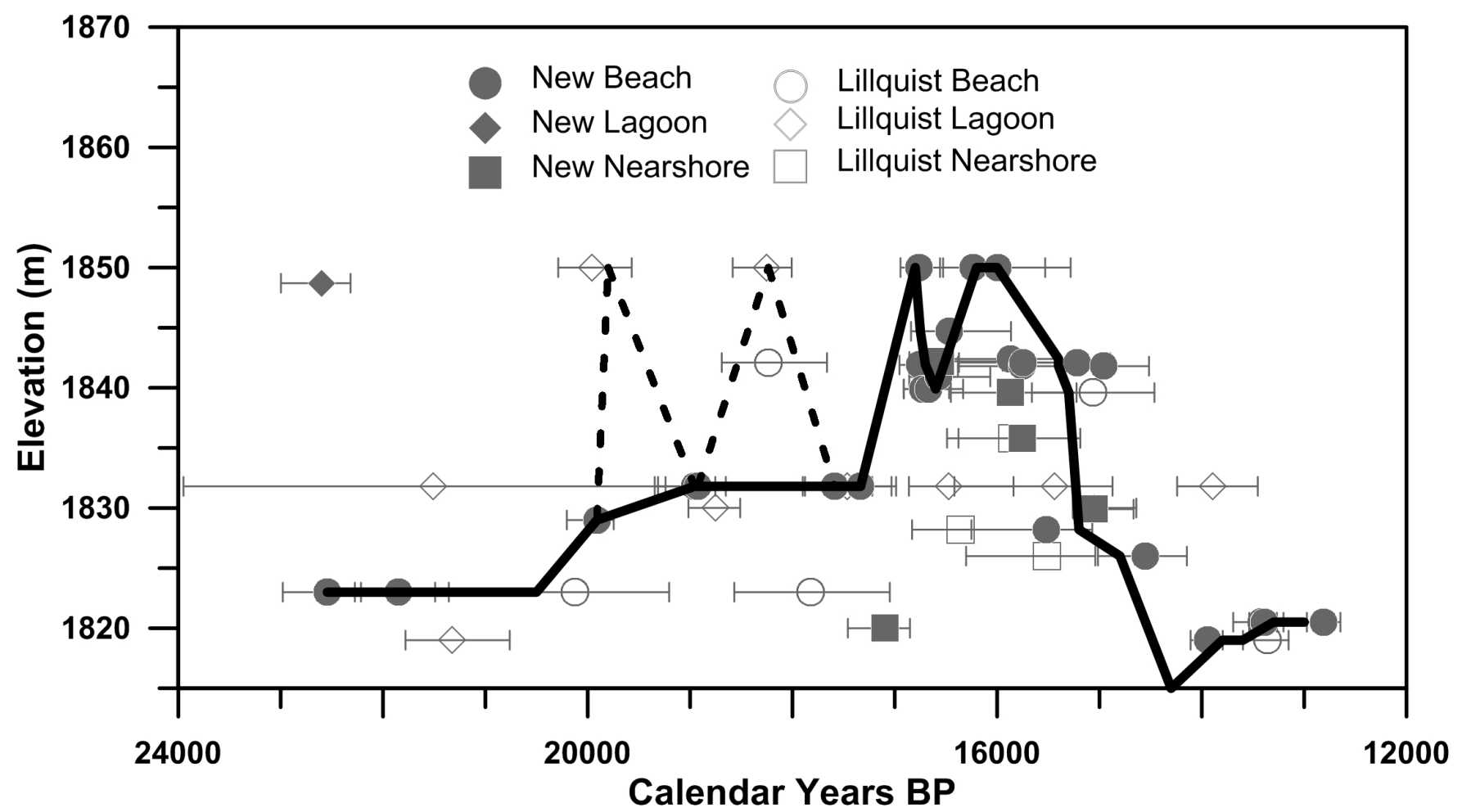

Figure 1.14. Hydrograph for Lake Franklin. Sources (Munroe and Laabs, 2013a and Lillquist, 1994) and facies (nearshore, lagoon, beach) of the radiocarbon ages are identified by separate symbols. The thick black line marks the reconstructed lake level during the last glacial-interglacial transition. Dotted lines mark possible transient departures to higher levels.

\section{Stop 3.4. Franklin River Bridge $\left(40.531851^{\circ} \mathrm{N}\right.$, $\left.-115.210585^{\circ} \mathrm{W}\right)$}

The road accessing the Franklin River Bridge follows a broad ridge that isolates the northern part of the Lake Franklin Basin (fig. 1.15). Lillquist (1994) interpreted this ridge as a compound spit/bayhead bar that was breached by Withington Creek and the Franklin River. In 2011, the east wall of the gravel pit at this location exposed $225 \mathrm{~cm}$ of finely bedded sandy gravel unconformably overlying a clayey silt with sand interbeds (fig. 1.16). Gastropod fossils from the sandy gravel yielded radiocarbon ages of 22 to $20 \mathrm{ka} \mathrm{BP}$, indicating that this beach ridge was constructed by Lake Franklin during the latter one-half of the Last Glacial Maximum (Lillquist, 1994; Munroe and Laabs, 2013a). During construction of the ridge, Lake Franklin had a maximum depth of about $9 \mathrm{~m}$ and covered 43 percent of its highstand area. The span of the radiocarbon results indicates that water stood at this elevation for about 2,000 years, which is consistent with the dimensions of the ridge (1.25 km wide and $12 \mathrm{~km}$ long). This evidence suggests that the climate during the LGM in Ruby Valley was stable, with effective moisture greater than modern, but less than at the pluvial maximum (Munroe and Laabs, 2013a). Submergence of this ridge, and reworking of the sediments, during the Lake Franklin highstand also could explain the anomalous wide, flat crest of this feature when compared with beach ridges at higher elevations.

\section{Directions to Stop 3.5}

Retrace the route back to the east and up to the CCC Road, and turn left to continue north. The road generally follows just below the shoreline at $1,850 \mathrm{~m}$, and in several places provides great overviews of the $1,843-\mathrm{m}$ shoreline to the west. After passing Hequy Well (at about $5 \mathrm{mi}$ ), where Lillquist (1994) obtained a date of $15,070 \pm 100{ }^{14} \mathrm{C}$ years BP on shells extracted from lagoon sediments east of the road, the road passes near a small cuspate spit formed as a paired of tombolos extended out to a small bedrock island when the lake stood at the 1,840-m level. North of this point, the shoreline is plastered on the side of a bedrock upland. After a few more miles, the road passes through an old gravel quarry, just before reaching NV-229 again. Park near the north end of the quarry for Stop 3.5. 


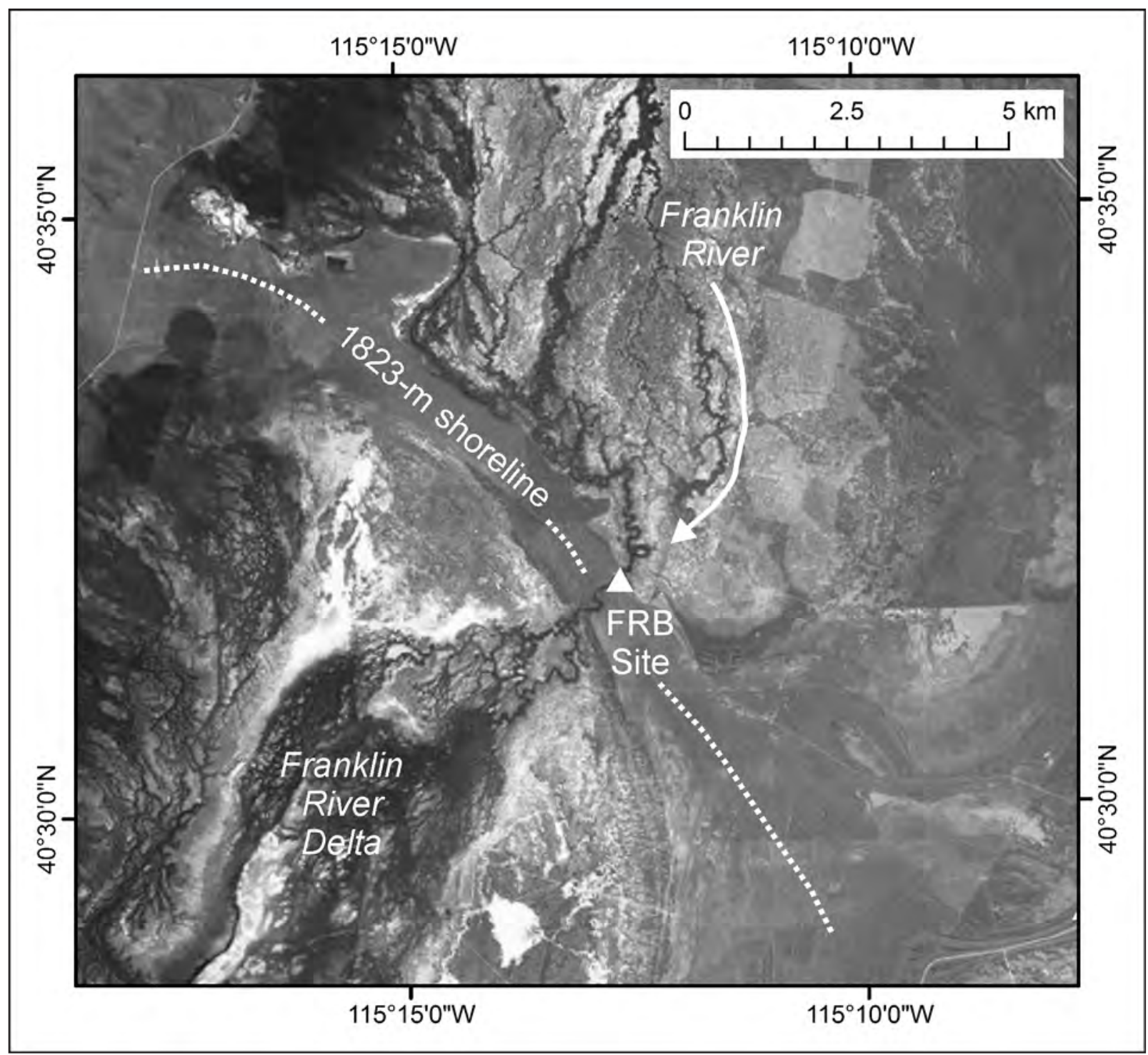

Figure 1.15. Aerial photograph of the Franklin River Bridge area. From Munroe and Laabs, 2013a. 

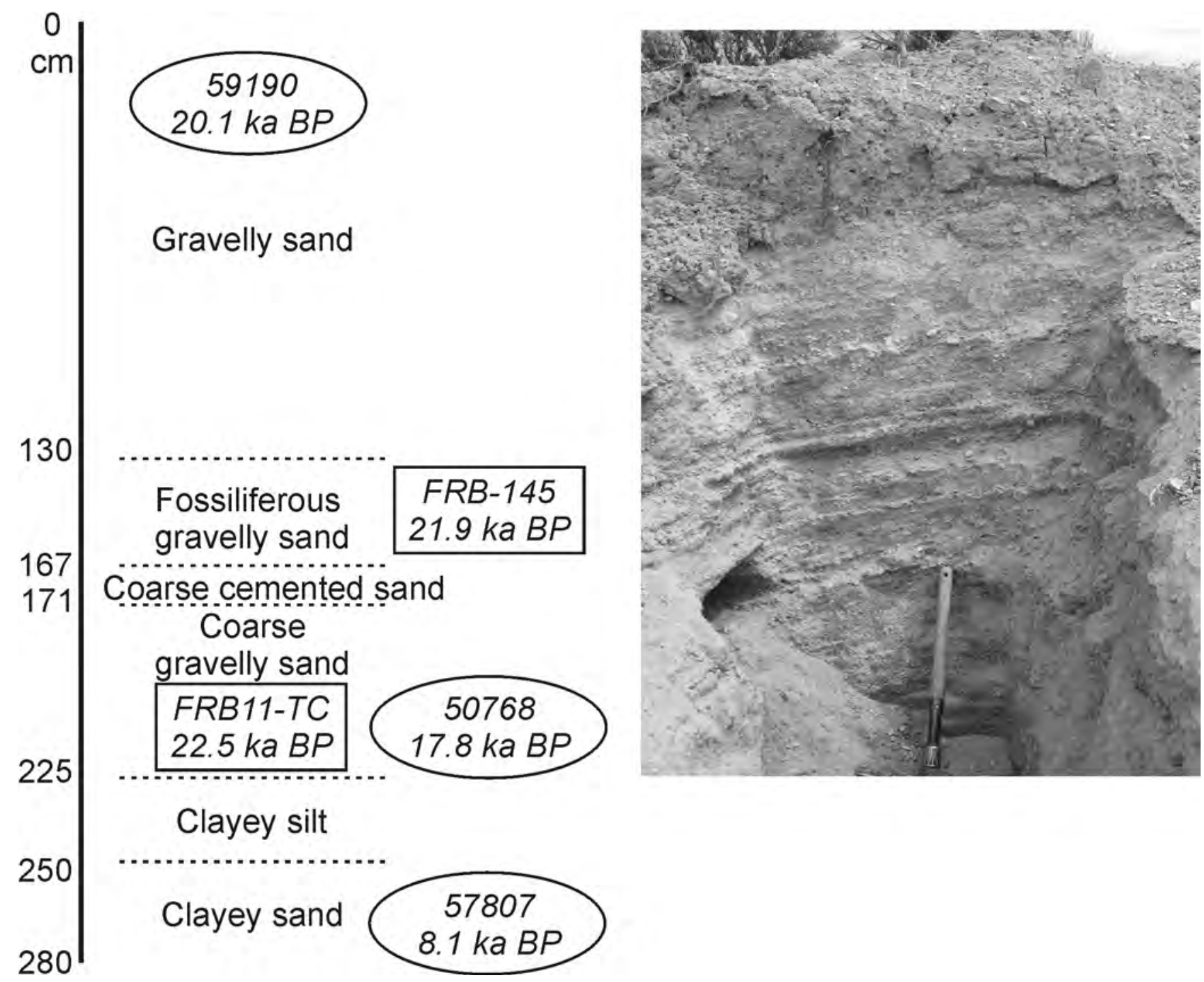

Figure 1.16. Photograph of stratigraphic section exposed at the east end of an excavation east of the Franklin River Bridge in June, 2010. From Munroe and Laabs (2013a). 


\section{Stop 3.5. Deep Gravel Quarry on CCC Road $\left(40.647220^{\circ} \mathrm{N}, 115.139360^{\circ} \mathrm{W}\right)$}

This final stop in Franklin Valley focuses on a gravel pit where material was removed from a compound beach ridge for road construction. The original elevation of the beach deposits at this location is difficult to determine because of the degree of disturbance; however, the quarried gravel appears to represent sediment that was deposited within a few meters of the highstand elevation. Coarse sandy gravel exposed in this pit in 2010 notably was cemented by carbonate (fig. 1.17). A shell sample from this cemented layer returned a date of $42,300 \pm 480{ }^{14} \mathrm{C}$ years BP (45,600 BP), indicating that these deposits predate the MIS-2 highstand. It is unclear how this date should be interpreted. It is not possible to determine if the age was skewed by contamination, but taken at face value, it suggests that a lake stood near the level of the MIS-2 highstand during MIS-3. Little is known about pre-MIS-2 lakes in the Great Basin, although older shorelines have been reported from some basins. In most cases, the ages of these features are unknown; however, work with a long sediment core from the Bonneville Basin suggests, not surprisingly, that deep lakes formed during glacial periods (Oviatt and others, 1999). Extrapolating this conclusion westward, it seems unlikely that Lake Franklin would have stood near its highest level for MIS-2 during the interstadial of MIS-3. However, perhaps this age represents a highstand of Lake Franklin in response to Heinrich Event 5 (H5, about 45 ka BP). Many pluvial lakes across the Great Basin reached highstands during Heinrich Event 1 (H1) about 16.8 ka BP (Munroe and Laabs, 2013b), as events in the North Atlantic shifted the hydrologic balance of the southwestern United States. Similarly, Lake Estancia in New Mexico was near its highstand during H2 about 23 ka BP (Allen and Anderson, 2000), at the same time that the abundance of Pediastrum began to increase in Lake Franklin, indicating a transition to less saline conditions (Thompson, 1992). If Great Basin pluvial lakes responded to atmospheric reorganizations during $\mathrm{H} 1$ and $\mathrm{H} 2$, then perhaps an increase in effective moisture briefly raised water levels during older Heinrich Events as well.

\section{Directions back to Wendover}

To return to Wendover, continue north on the CCC Road a short distance to intersect NV-229. Turn right, cross of the divide leaving Ruby Valley, and turn left on US-93. Pass through Clover Valley on the way back up to Wells, then head east on I-80 to Wendover.

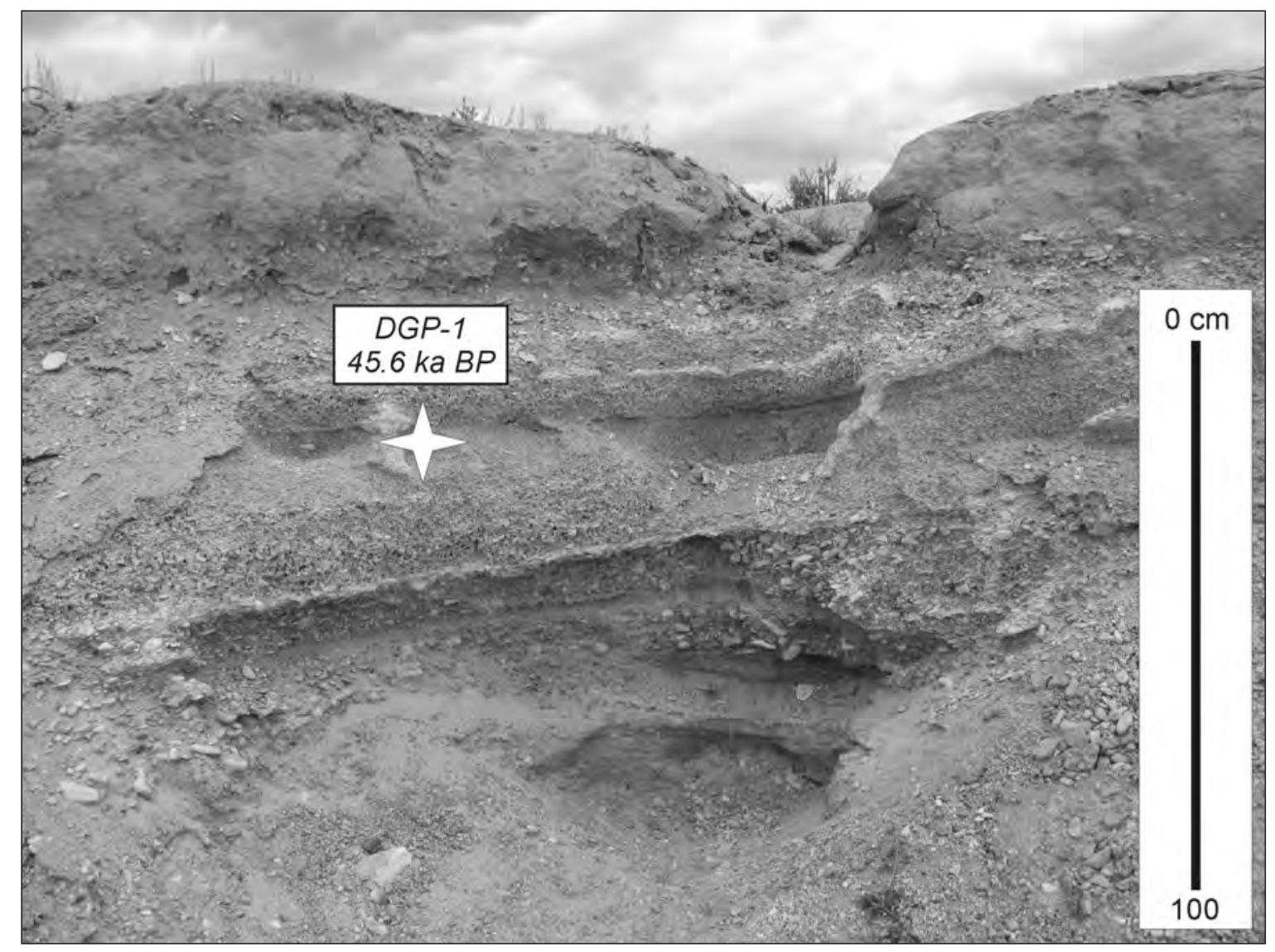

Figure 1.17. Photograph of the Deep Gravel Quarry exposure at the north end of the CCC Road. From Munroe and Laabs (2013a). Photograph by Jeff Munroe, Middlebury College, July 26, 2006. 


\section{DAY 4. The Angel Lake Type Locality}

(Driving Distance approximately $425 \mathrm{mi} / 685 \mathrm{~km}$ )

\section{Day 4 Overview}

The final day of this field trip will focus on the region around Angel Lake in the East Humboldt Mountains near Wells, Nevada. Sharp (1938) designated Angel Lake as the type locality of the last Pleistocene glaciation in the Great Basin. Recent work has generated a more detailed view of the distribution of moraines in this valley, and has assigned ages to these landforms through cosmogenic ${ }^{10}$ Be surfaceexposure dating. Paleolimnological investigations of sediment cores from Angel Lake, as well as other high-elevation lakes in the Ruby Mountains, also have shed light on Holocene environmental change in this area.

\section{Directions to Stop 4.1}

From Wendover, drive west on I-80 to Wells, Nevada. Take exit 351 (one exit past US-93), turn left under the highway, and then right on Angel Lake Road (NV-231). Follow this road towards the mountains. After passing the left turn into Angel Creek Campground, the road climbs a series of switchbacks up the mountain front and into the cirque holding Angel Lake.
Note that this road is extremely steep, narrow, and winding. Park in the first parking lot on the right of the road after the final left turn into the cirque. From the parking lot, walk back down the road a few hundred meters, then climb upslope to the south (right) to reach the crest of the Angel Lake-age right-lateral moraine.

\section{Stop 4.1. Angel Lake Right-Lateral Moraine $\left(41.025608^{\circ} \mathrm{N}, 115.077074^{\circ} \mathrm{W}\right)$}

The drive from Wells, Nevada, toward Angel Lake affords tremendous views of terminal moraines at the type locale for the Angel Lake Glaciation (Sharp, 1938). Here, in the northeastern sector of the East Humboldt Range, a 3-km-long glacier constructed latero-frontal moraines that form a nearly continuous terminal moraine loop in the Angel Creek drainage (fig. 1.18). As noted by Osborn and Bevis (2001), the moraine crest (at 2,317 m) is bouldery, displays low-relief hummocky topography, and has a steep ice-distal slope with about $60 \mathrm{~m}$ of relief. Parts of the distal slope grade to an outwash fan that forms the surface underlying the Angel Creek Campground. Elsewhere, till comprising the distal slope is inset to older, possibly Lamoille-equivalent moraines with relatively low relief and few, deeply weathered erratic boulders at the crest.

\section{Angel Lake Type Locale}

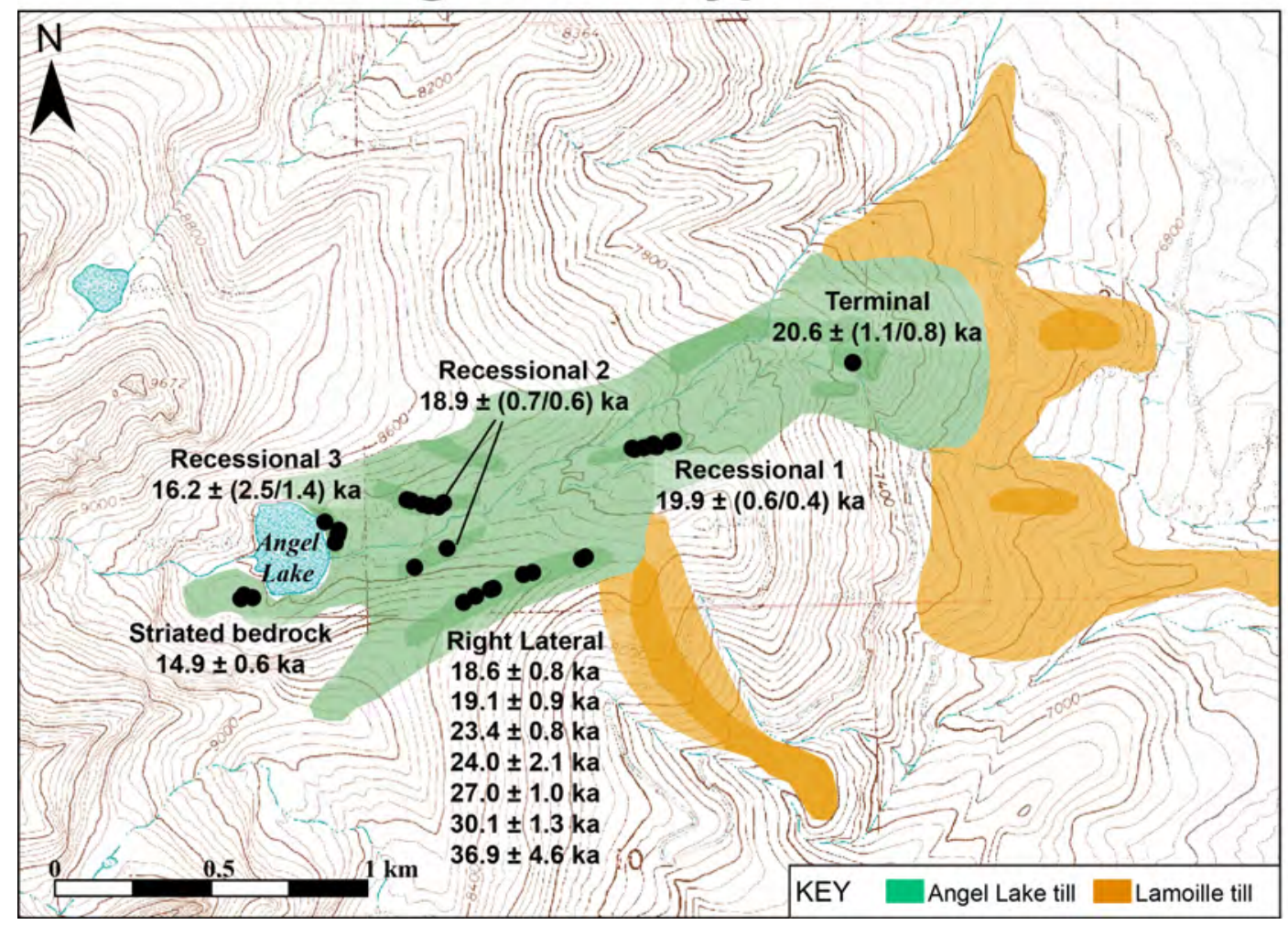

Figure 1.18. Map of moraines and cosmogenic ${ }^{10} \mathrm{Be}$ surface-exposure ages at the LGM Angel Lake type locality. 
Along the southern slope of the terminal moraine, a recent breach exposes till comprising the landform. The exposed diamicton bears physical properties typical of sediments comprising alpine moraines-poorly sorted with a coarsegrained sandy matrix, clasts consisting of local lithologies (chiefly granodiorite and gneiss), and clast sizes ranging from pebbles to large boulders. Weathering profiles in the till near the top of this and other exposures are consistent with those of Angel Lake-equivalent till elsewhere in the region (Wayne, 1984; Bevis, 1995) and support correlation of the Angel Lake Glaciation to the Wisconsin Glaciation (Richmond, 1986). X-ray diffraction analysis of samples from within the weathering profile indicates the presence of pedogenic kaolinite and vermiculite that are absent in the unweathered till (Bigl and others, 2011).

At Stop 4.1, the bouldery crest of the right-lateral moraine rises approximately $35 \mathrm{~m}$ above the road and is continuous over a distance of about $0.7 \mathrm{~km}$ (fig. 1.19). It pairs with a left-lateral moraine that is visible to the north across Angel Creek; together, these moraines delimited the vertical extent of the glacier in this valley during the Angel Lake Glaciation (fig. 1.18). The frequency of erratic boulders at the moraine crest increases upvalley. Although some of these boulders display clear evidence of substantial surface erosion, many are tall enough and display glacial polish and (or) resistant quartz-rich protrusions to render them suitable for cosmogenic ${ }^{10}$ Be surface-exposure dating. Seven ${ }^{10} \mathrm{Be}$ exposure ages from this moraine limit the time when it was last occupied by ice (table 1-3). The reason for the broad variability of these exposure ages, spanning from $18.6 \pm 0.8 \mathrm{ka}$ to $36.9 \pm 4.6 \mathrm{ka}$, is unclear. Field observations do not suggest that differential snow cover or surface erosion disrupted the exposure history of any boulders. Instead, the observed range of exposure ages could reflect (1) inherited ${ }^{10} \mathrm{Be}$ inventory for some of the boulders due to their short distance of glacial transport $(<2 \mathrm{~km})$ downvalley from their bedrock source, or (2) multiple periods or persistent occupation of the lateral moraine by the glacier. Given these possibilities, the time of the Angel Lake Maximum is inferred from ${ }^{10} \mathrm{Be}$ exposure ages of boulders atop the terminal moraine, downvalley (east) of this site, which provided a clearer limit of the time of maximum glacier length.

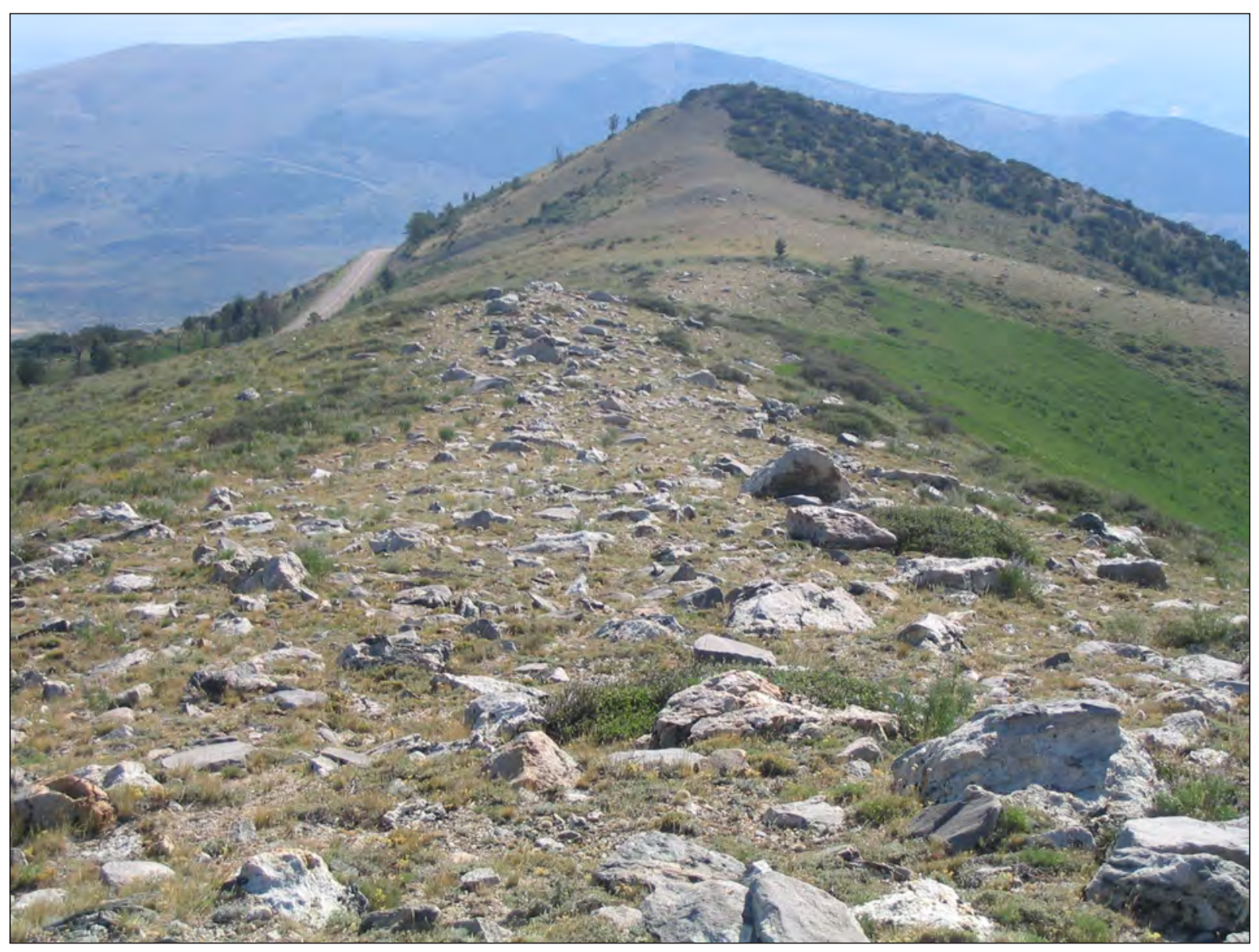

Figure 1.19. Photograph of the right-lateral moraine at Angel Lake (Stop 4.1). 
Table 1.3. Cosmogenic ${ }^{10} \mathrm{Be}$ exposure ages of glacial features in Angel Creek valley.

[Exposure ages are based on measured ${ }^{10} \mathrm{Be}$ concentrations in samples prepared at the SUNY Geneseo Cosmogenic Nuclide Lab and analyzed at the Purdue Rare Isotope Laboratory (PRIME Lab, Purdue University). Ages were computed by version 2.2 of the CRONUS Earth online exposure age calculator (http://hess.ess.washington.edu; Balco and others, 2008) with the globally averaged production rate model of Heyman (2014) and the $\mathrm{Lal} /$ Stone constant-production scaling model. Sample IDs and exposure ages in italics are not used to compute error-weighted mean exposure age. Contact B. Laabs for additional information about samples and laboratory procedures]

\begin{tabular}{|c|c|c|c|c|}
\hline Surface & Sample ID & $\begin{array}{c}{ }^{10} \mathrm{Be} \text { exposure age } \\
(\mathrm{ka} \pm 1 \sigma)^{*}\end{array}$ & $\begin{array}{l}\text { Error-weighted mean } \\
\text { exposure age } \\
(\mathrm{ka} \pm 2 \sigma)\end{array}$ & $\begin{array}{c}\text { Bayesian } \\
\text { exposure age } \\
\text { (ka } \pm 95 \% \text { conf.) }\end{array}$ \\
\hline $\begin{array}{l}\text { Right Lateral Moraine } \\
\text { (Stop 4.1) }\end{array}$ & $\begin{array}{l}\text { ALR-8 } \\
\text { ALR-2 } \\
\text { ALR-7 } \\
\text { ALR-6 } \\
\text { ALR-1 } \\
\text { ALR-5 } \\
\text { ALR-4 }\end{array}$ & $\begin{array}{l}18.6 \pm 0.8 \\
19.1 \pm 0.9 \\
23.4 \pm 0.8 \\
24.1 \pm 2.1 \\
27.0 \pm 1.0 \\
30.1 \pm 1.3 \\
36.9 \pm 4.6\end{array}$ & - & - \\
\hline Terminal Moraine & $\begin{array}{l}\text { ALT-1 } \\
\text { ALT-4 } \\
\text { ALT-3 }\end{array}$ & $\begin{array}{l}19.8 \pm 1.2 \\
20.1 \pm 0.8 \\
21.4 \pm 1.7\end{array}$ & $20.2 \pm 1.3$ & $20.6 \pm(1.1 / 0.8)$ \\
\hline Recessional Moraine 1 & $\begin{array}{l}\text { ALI-5 } \\
\text { ALI-2 } \\
\text { ALI-8 } \\
\text { ALI-4 } \\
\text { ALI-6 } \\
\text { ALI-3 } \\
\text { ALI-1 }\end{array}$ & $\begin{array}{l}18.6 \pm 0.9 \\
19.0 \pm 0.8 \\
19.8 \pm 0.8 \\
20.0 \pm 0.7 \\
20.3 \pm 0.8 \\
21.2 \pm 0.8 \\
21.9 \pm 0.8\end{array}$ & $20.0 \pm 0.6$ & $19.9 \pm(0.6 / 0.4)$ \\
\hline Recessional Moraine 2 & $\begin{array}{l}\text { ALI-13 } \\
\text { ALI-9 } \\
\text { ALI-15 } \\
\text { ALI-10 } \\
\text { ALI-16 }\end{array}$ & $\begin{array}{c}18.5 \pm 0.7 \\
18.8 \pm 0.7 \\
18.9 \pm 0.7 \\
19.8 \pm 0.7 \\
24.7 \pm 0.9 \dagger\end{array}$ & $19.0 \pm 0.7$ & $18.9 \pm(0.7 / 0.6)$ \\
\hline $\begin{array}{l}\text { Recessional Moraine } 3 \\
\text { (Stop 4.2) }\end{array}$ & $\begin{array}{l}A L D-4 \\
A L D-1 \\
\text { ALD-2 } \\
\text { ALD-3 }\end{array}$ & $\begin{array}{c}10.6 \pm 1.2 \S \\
11.4 \pm 0.8 \S \\
14.2 \pm 0.9 \\
17.4 \pm 0.6\end{array}$ & $15.8 \pm 4.6 \#$ & $16.2 \pm(2.5 / 1.4)$ \\
\hline Glacially Polished Bedrock & $\begin{array}{l}\text { AAL12-3 } \\
\text { AAL12-1 } \\
\text { AAL12-2 }\end{array}$ & $\begin{array}{c}14.9 \pm 0.6 \\
18.9 \pm 0.8^{* *} \\
19.6 \pm 0.8^{* *}\end{array}$ & $14.9 \pm 0.6$ & $14.9 \pm 0.6$ \\
\hline
\end{tabular}

${ }^{*}$ Uncertainty is based on measurement error and scaling for sample thickness.

${ }^{\dagger}$ Age rejected because it is older than the exposure ages of moraines downvalley.

${ }^{\S}$ Ages rejected because they are younger than the exposure age of the glacially polished surface upvalley.

${ }^{*}$ Mean exposure age $\pm 2 \sigma$.

${ }^{* *}$ Ages rejected because they are older than the exposure age of Recessional 3 moraine downvalley. 
To limit the time of the Angel Lake Maximum as precisely as possible with cosmogenic exposure dating, ${ }^{10}$ Be ages of the terminal moraine, three recessional moraines and a glacially striated bedrock surface upvalley of Angel Lake were evaluated using a Bayesian statistical analysis (cf. Buck and others, 1996). This type of analysis is useful for resolving and improving the precision of overlapping numerical ages of strata or surfaces with clear relative age relationships (e.g., Buck and others, 1996; Rhodes and others, 2003). The analysis used here (coded by Ludwig, 2003) considers the observed exposure age of each moraine (represented here by the error-weighted mean $\pm 2 \sigma$ ) and the relative ages of the moraines, such that moraines are younger upvalley. The reported best age of each moraine (fig. 1.18, table 1.3) is the modal age computed by a Monte Carlo simulation of the Bayesian analysis (Ludwig, 2003); hence, the unequal errors of each age ( \pm 95 -percent confidence interval).

This approach yields a ${ }^{10} \mathrm{Be}$ exposure age for the terminal moraine of $20.6 \pm(1.1 / 0.8) \mathrm{ka}$, overlapping the four youngest exposure ages of the lateral moraine at this site and the exposure ages of terminal moraines elsewhere in the RubyEast Humboldt Mountains (Laabs and others, 2013). This age suggests that the glacier here attained its maximum length during the time of the global LGM.

Looking across the valley to the north, a well-preserved sequence of recessional moraines is visible as boulder-strewn lower ridges inset to the outermost lateral moraines along the axis of the Angel Creek valley (fig. 1.18). These moraines clearly track the path of ice retreat after the maximum of the Angel Lake Glaciation, with the youngest, innermost moraine impounding the northeastern side of Angel Lake. When compared to the ${ }^{10} \mathrm{Be}$ exposure age of the terminal moraine, the exposure ages of the recessional moraines (fig. 1.18) indicate a 30-percent reduction in glacier length by $19.9 \pm(0.6 / 0.4) \mathrm{ka}$, a 50 -percent reduction in length by $18.9 \pm(0.7 / 0.6) \mathrm{ka}$, and a 70 -percent reduction in length by $16.2 \pm(2.5 / 1.4) \mathrm{ka}$. Corresponding minimum retreat rates are $1.1 \mathrm{~m} / \mathrm{yr}$ from the terminal to recessional 1 moraine, $0.8 \mathrm{~m} / \mathrm{yr}$ from the recessional 1 to recessional 2 moraine, and $0.2 \mathrm{~m} / \mathrm{yr}$ from the recessional 2 to recessional 3 moraine. Overall retreat of the glacier terminus, with brief intervals of still-stands or re-advances, indicates a significant change in climate during the latter part of the global LGM and deglaciation.

The view to the southeast encompasses much of the landscape inundated by pluvial Lake Clover, including the Independence (eastern) and Clover (western) basins. Far to the south, the Snow Water Lake playa is visible, representing the low point of the Clover basin. Numerical modeling of glaciers in the Ruby-East Humboldt Mountains and of Lake Clover during times of both glacier and lake maxima (e.g., about $19.1 \mathrm{ka}$ and $17.0 \mathrm{ka}$; Laabs and others, 2013) helps to identify unique temperature and precipitation combinations for the late LGM and subsequent deglaciation. Ongoing numerical modeling of modern and paleohydrology of the Lake Clover basin by Grogan and others (2015) applies a modified water balance modeling method of Condom and others (2004) to generate a set of temperature and precipitation combinations during the Lake Clover highstands at 19.5 and 17.3 ka. Numerical modeling of multiple valley glaciers that occupied moraines in the Ruby-East Humboldt Mountains at the same time as the lake highstands applies modified mass balance and ice flow methods of Plummer and Phillips (2003) to generate a set of temperature and precipitation combinations accompanying the reconstructed ice extent. The combined model results suggest that a temperature depression of $6.5-9^{\circ} \mathrm{C}$ with corresponding precipitation of 2.6-1.8x modern accompanied lake highstands (fig. 1.20). This inferred increase in precipitation is greater than that from many previous reconstructions of pluvial lakes (e.g., Mifflin and Wheat, 1979; Matsubara and Howard, 2009; Ibarra and others, 2014), and strongly suggests that the greatest hydrologic input to the lakes was direct precipitation and not runoff.

\section{Directions to Stop 4.2}

Carefully descend the proximal moraine slope to the road, turn left, and walk up to final parking lot (straight ahead after the cattle guard). Pass through the lot and continue the remaining short distance to the dam impounding Angel Lake. 


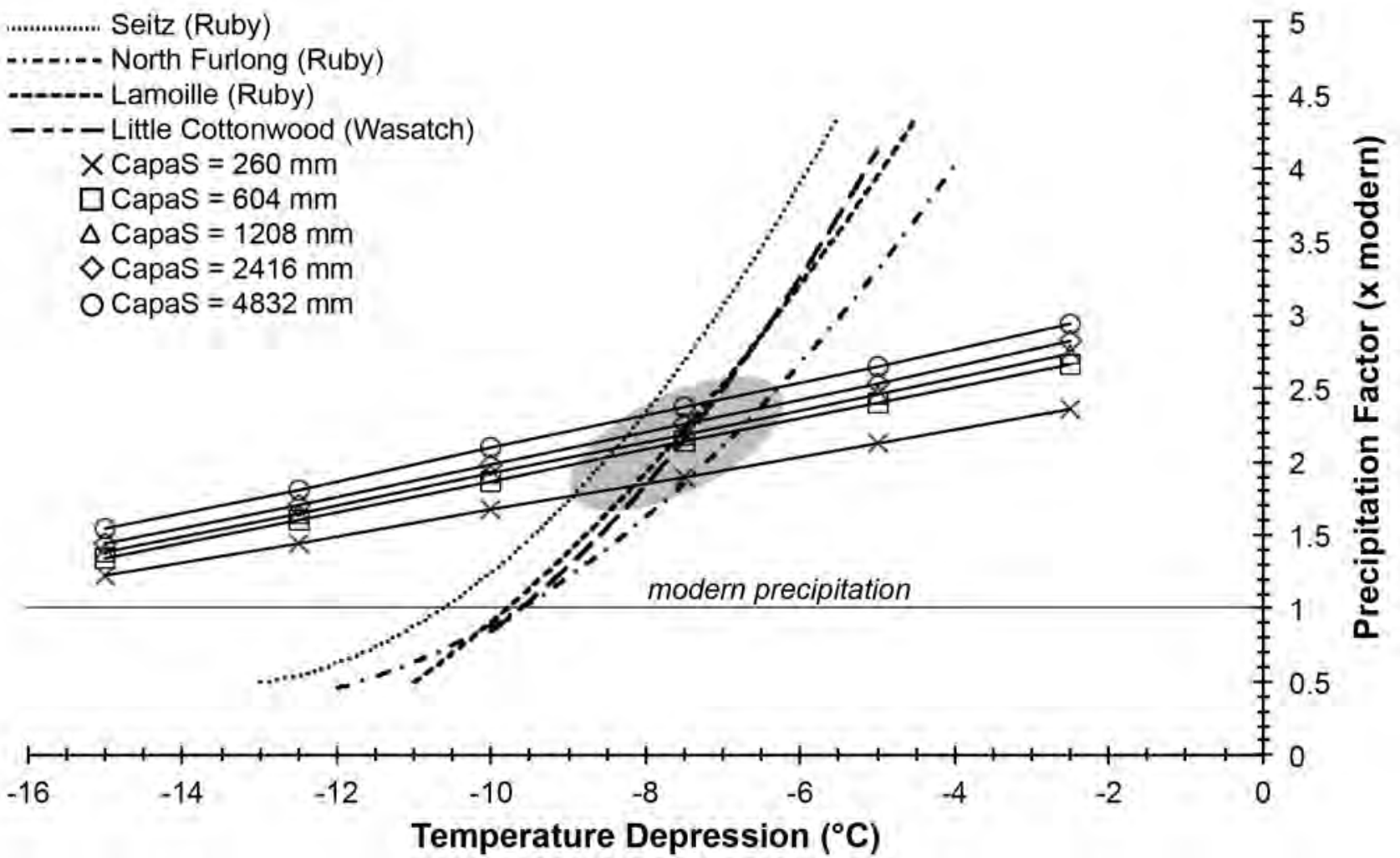

Figure 1.20. Results from numerical modeling of glaciers in the Ruby and Wasatch Mountains and for pluvial Lake Clover. The two sets of results intersect at a temperature depression of $\sim 8^{\circ} \mathrm{C}$ and a precipitation increase of $\sim 2.5 \mathrm{x}$.

\section{Stop 4.2. Angel Lake and Recessional Moraine 3 $\left(41.026054^{\circ} \mathrm{N}, 115.085446^{\circ} \mathrm{W}\right)$}

Angel Lake is a natural tarn at 2,554 m that was slightly enlarged by a dam in the early 1900s. The setting is quite scenic (fig. 1.21), and that quality combined with the easy access from Wells and I-80, makes this a popular spot. Snow melting higher in the cirque during early summer feeds an impressive cataract that enters the lake opposite the dam. A tremendous headwall rising $700 \mathrm{~m}$ to Greys Peak encircles the lake on three sides, while a pair of steep-sided lateral moraines extends eastward from the lake along the road.

The natural dam for Angel Lake is a recessional moraine (shown as Recessional 3 in fig. 1.18). The moraine features a small number of erratic boulders with ${ }^{10} \mathrm{Be}$ exposure ages varying from $10.6 \pm 1.2 \mathrm{ka}$ to $17.4 \pm 0.6 \mathrm{ka}$. A glacially polished bedrock surface just upvalley of Angel Lake yields an exposure age of $14.9 \pm 0.7$ (table 1-2), whereas two erratic boulders resting on this surface yielding exposure ages older than the oldest boulder exposure age of the moraine. These two ages of $19.6 \pm 0.8 \mathrm{ka}$ and $18.9 \pm 0.9 \mathrm{ka}$ suggest that the boulders were derived from a depth insufficient $(<2.5 \mathrm{~m})$ to remove the inventory of cosmogenic ${ }^{10} \mathrm{Be}$ inherited from a prior interval of exposure. Assuming that the exposure age of the glacially striated surface does not reflect an inherited ${ }^{10}$ Be inventory (i.e., a glacial scour depth $>2.5 \mathrm{~m}$ ), then this age can be used to assess the accuracy of ${ }^{10} \mathrm{Be}$ exposure ages of the Recessional 3 moraine. Because the two youngest ${ }^{10} \mathrm{Be}$ exposure ages of the moraine (10.6 $\pm 1.2 \mathrm{ka}$ and $11.4 \pm 0.8 \mathrm{ka})$ are younger than the exposure age of the glacially polished surface up valley, these ages likely reflect differential shielding of boulders by snow or sediment at some point in their exposure history. Due to the low relief of the Recessional 3 moraine and the glacially polished surface sampled for cosmogenic ${ }^{10} \mathrm{Be}$ exposure dating, the effect of snow cover on the exposure history of all samples is likely significant and requires additional consideration.

Laabs and Munroe retrieved a sediment core from Angel Lake in June 2007. Coring was completed from an anchored platform using a Livingstone corer for the loose surface sediment, and a percussion corer for deeper material. The cores were retrieved in $9.14 \mathrm{~m}$ of water, and the composite record extended from the sediment-water interface to a depth of $4.54 \mathrm{~m}$ below the lake bottom. The basal sediment of the percussion core contains tephra, and OSL analysis returned an age (7.94 $\pm 0.9 \mathrm{ka} \mathrm{BP})$ consistent with the Mazama eruption. That constraint, along with 5 AMS radiocarbon dates, supports a depth-age model that spans about $7.7 \mathrm{ka} \mathrm{BP}$.

Multiple sedimentary properties were investigated in this core at 1-cm intervals including: (1) water content, (2) loss-onignition (LOI), (3) carbon-to-nitrogen $(\mathrm{C}: \mathrm{N})$ ratio, (4) biogenic silica content, and (5) grain size distribution (Munroe and Laabs, 2009). LOI and water content show significant transient 


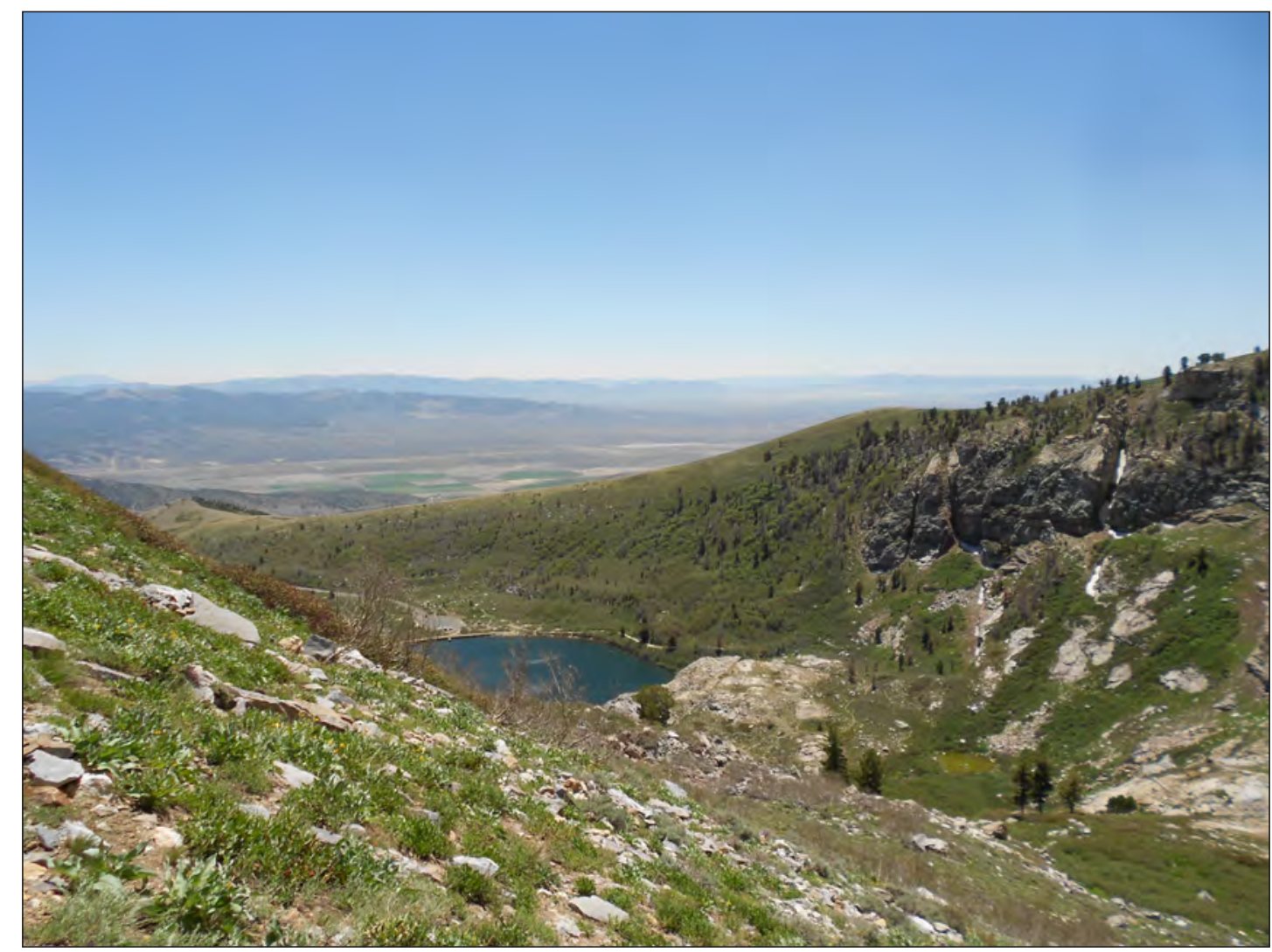

Figure 1.21. Photograph of Angel Lake. The prominent right-lateral moraine constructed by the Angel Lake Glacier is visible on the far side of the lake (Stop 4.1). Photograph by Emily Attwood, Middlebury College, June 25, 2012.

departures from an overall increasing trend through the record (fig. 1.22). Biogenic silica and LOI values are notably above average from 1 to $2 \mathrm{ka}$ BP and ca. $7 \mathrm{ka}$ BP, suggesting a warmer, more productive lake environment. These episodes of increased productivity are broadly consistent with times of increased chironomid-inferred July air temperatures at Stella Lake in Great Basin National Park, $250 \mathrm{~km}$ to the south (Reinemann and others, 2009). In particular, the interval of peak warmth at Stella Lake ca. 5.5 ka BP is synchronous with an interval of particularly high LOI values. Higher LOI values in the later Holocene overlap with times of reconstructed high water levels in Ruby Lake to the southeast, as well as Pyramid Lake and Lake Tahoe at the western end of the Great Basin. Together, these similarities suggest a general increase of both relative moisture and productivity in high-elevation lakes in the late Holocene.

Mean grain size in the Angel Lake record is highly variable, with spikes to locally high values reflecting delivery of clastic debris to the coring site by high-energy events (fig. 1.22). Because the core was retrieved from the opposite side of the depocenter from the inlet in water about $2 \mathrm{~m}$ shallower than the deepest part of the basin, it is unlikely that these clastic layers are evidence of direct fluvial inputs. Instead, these layers are interpreted to represent depositional events during the winter and spring when run-out from snow avalanches and slushflows could travel across the ice to the coring site (Munroe and Laabs, 2009). To objectively identify these discrete events in the record, a Gaussian smoothing function was run through the grain size time series and avalanche events were defined as peaks rising above the local background level. Results from this analysis indicate that the frequency of avalanches was below average from 1.8 to $3.2 \mathrm{ka}$ $\mathrm{BP}$, which overlaps the extended low in LOI. In contrast, avalanches were quite common, up to 2-times the long-term average, from 0.5 to $1.5,3.2$ to 3.8 , and from 4.5 to $6.5 \mathrm{ka}$ $\mathrm{BP}$. The oldest interval is synchronous with a prolong interval of warm temperatures at Stella Lake, as well as lowstands in Ruby Lake, Pyramid Lake, and Lake Tahoe. Together, these fluctuations may reflect changes in winter/spring moisture delivery to the northeastern Great Basin. Alternatively, increases in avalanche frequency may indicate more common rain on-snow events or episodes of rapid warming during the spring thaw, both of which could stimulate wet avalanches and slushflows.

\section{Directions back to Reno}

Retrace the route back to I-80 using caution on the steep descent, particularly if driving a fully loaded van. Use of lower gear is recommended in order to prevent brakes from overheating. Pass under the highway and turn left to access I-80 westbound. Follow I-80 west to Reno ( $340 \mathrm{mi} / 550 \mathrm{~km}$, $43 / 4$ hours). 

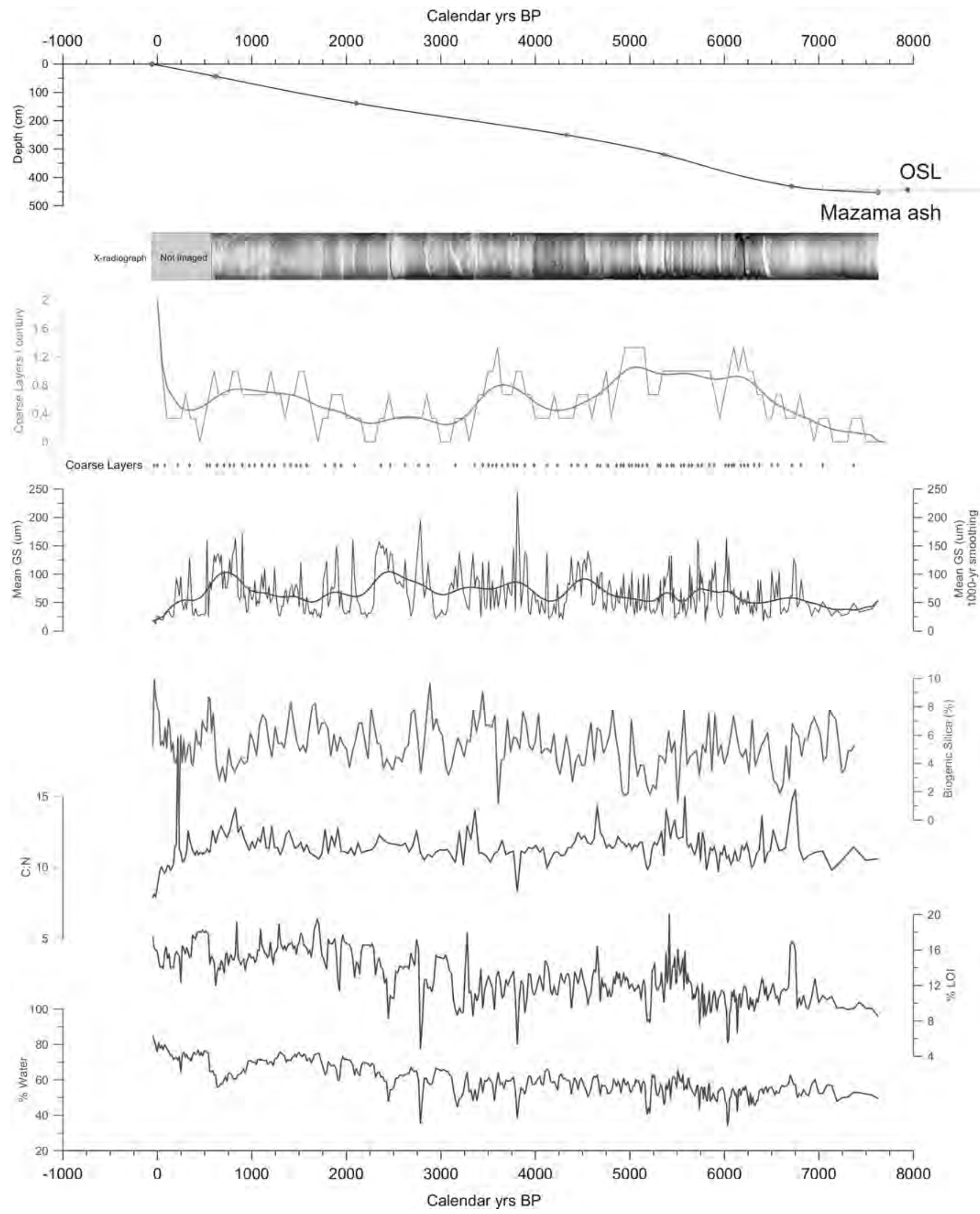
Figure 1.22. (On previous page) Multiproxy time-series from the Angel Lake core. Water content rises through the record, reflecting compacting of sediment over time. Loss-on-ignition (LOI, a proxy for organic matter content) also rises, with significant departures from this overall trend. C:N ratio varies reflecting the relative input of terrestrial vs. aquatic debris. Biogenic silica values vary widely, perhaps reflecting changes in summer water temperature and/or duration of the ice-free season. Mean grain size (GS) is also highly variable. The analysis described in the text yielded an objective identification of coarse layers inferred to record wet avalanches onto the lake ice. The frequency of these events was highest in the middle Holocene, and ca. 3500 and 1000 years BP. The thicker coarse layers are visible as light gray bands on the X-radiograph. The depth-age model was based on five AMS ${ }^{14} \mathrm{C}$ dates, the year A.D. 2007 for the core surface, the presence of tephra assumed to be from the Mazama eruption near the base, and an OSL analysis on the basal sediment. From Munroe and Laabs (2011).

\section{Acknowledgments}

Work in northeastern Nevada was supported by NSF-P2C2-0902586 to Munroe, NSF-P2C2-0902472 to Laabs, NSF-BCS-0808861 to Munroe, and a GSA QG\&G Division Gladys W. Cole Memorial Research award to Laabs. Munroe and Laabs thank the Humboldt-Toiyabe National Forest and the Bureau of Land Management for permission to conduct this research on Federal land. Oviatt acknowledges Don Clark, Don Currey, David Madsen, and Dave Miller for help with field work and many useful discussions of the geology and geomorphology in the Wendover area.

\section{References Cited}

Allen, B.D., and Anderson, R.Y., 2000, A continuous, highresolution record of late Pleistocene climate variability from the Estancia Basin, New Mexico: Geological Society of America Bulletin, v. 112, p. 1,444-1,458.

Antevs, E.V., 1948, The Great Basin, with emphasis on glacial and postglacial times; Climatic changes and pre-white man: Bulletin of the University of Utah, v. 38, p. 168-191.

Balco, G., Stone, J., Lifton, N., and Dunai, T., 2008, A complete and easily accessible means of calculating surface exposure ages or erosion rates from ${ }^{10} \mathrm{Be}$ and ${ }^{26} \mathrm{Al}$ measurements: Quaternary Geochronology, v. 3, p. 174-195.

Bartlein, P.J., Anderson, K.H., Anderson, P.M., Edwards, M.E., Mock, C.J., Thompson, R.S., Webb, R.S., Webb, T., III, and Whitlock, C., 1998, Paleoclimate simulations for North America over the past 21,000 yearsFeatures of the simulated climate and comparisons with paleoenvironmental data: Quaternary Science Reviews, v. 17 , p. 549-585.

Benson, L.V., Lund, S.P., Smoot, J.P., Rhode, D.E., Spencer, R.J., Verosub, K.L., Louderback, L.A., Johnson, C.A., Rye, R.O., and Negrini, R.M., 2011, The rise and fall of Lake Bonneville between 45 and 10.5 ka: Quaternary International, v. 235, p. 57-69.
Bevis, K.A., 1995, Reconstruction of late Pleistocene paleoclimatic characteristics in the Great Basin and adjacent areas: Corvallis, Oregon State University, Ph.D. thesis, $291 \mathrm{p}$.

Bigl, M.F., Rosenberg, B.D., Ryan, P.C., and Munroe, J.S., 2011, X-ray diffraction analysis of weathering patterns in high-elevation glacial, periglacial, and eolian sediments in northern Nevada and Utah: Geological Society of America Abstracts with Programs, v. 43, no. 1, p. 114.

Blackwelder, Eliot, 1931, Pleistocene glaciation in the Sierra Nevada and Basin Ranges: Geological Society of America Bulletin, v. 42, no. 4, p. 865-922.

Blackwelder, Eliot, 1934, Supplementary notes on Pleistocene glaciation in the Great Basin: Journal of the Washington Academy of Sciences, v. 24, no. 5, p. 217-222.

Bowen, B., Kleba, B., Turner, J., and Raming, L.W., 2014, Sedimentology, mineralogy, geochemistry, and geomicrobiology of the Bonneville Salt Flats: Geological Society of America Abstracts with Programs, v. 46, no. 6, p. 410.

Buck, C.E., Cavanagh, W.G., and Litton, C.D., 1996, Bayesian approach to interpreting archaeological data: Chichester, United Kingdom, Wiley, 402 p.

Condom, T., Coudrain, A., Dezetter, A., Brunstein, D., Delclaux, F., and Sicart, J.-E., 2004, Transient modeling of lacustrine regressions - Two case studies from the Andean Altiplano: Hydrological Processes, v. 18, p. 2,395-2,408.

Currey, D.R., 1982, Lake Bonneville-Selected features of relevance to neotectonic analysis: U.S. Geological Survey Open-File Report 82-1070, 31 p.

Duffy, C.J., and Al-Hassan, S., 1988, Groundwater circulation in a closed desert basin-Topographic scaling and climate forcing: Water Resources Research, v. 24, p. 1,675-1,688.

Felton, A., Jewell, P.W., Chan, M., and Currey, D., 2006, Controls of tufa development in Pleistocene Lake Bonneville, Utah: Journal of Geology, v. 114, p. 377-389.

Gilbert, G.K., 1890, Lake Bonneville: U.S. Geological Survey Monograph 1, 438 p. 
Grogan, A.L., Laabs, B.J.C., Steen, D.P., Amidon, W.H., and Munroe, J.S., 2015, Constraining modern and paleohydrology of the Lake Clover and Lake Franklin pluvial systems, northeastern Nevada, Great Basin, U.S.A.: Geological Society of America Abstracts with Programs, v. 47 , no. 3, p. 97.

Heyman, J., 2014, Paleoglaciation of the Tibetan Plateau and surrounding mountains based on exposure ages and ELA depression estimates: Quaternary Science Reviews, v. 91, p. 30-41.

Ibarra, D.E., Egger, A.E., Weaver, K.L., Harris, C.R., and Maher, K., 2014, Rise and fall of late Pleistocene pluvial lakes in response to reduced evaporation and precipitation-Evidence from Lake Surprise, California: Geological Society of America Bulletin, v. 126, nos. 11-12, p. $1,387-1,415$.

Jennings, J.D., 1957, Danger cave: Salt Lake City, University of Utah Press, University of Utah Anthropological Paper 27, $328 \mathrm{p}$.

Kutzbach, J.E., 1987, Model simulations of the climatic patterns during the deglaciation of North America, chap. 19 of Ruddiman, W.F., and Wright, H.E., Jr., eds., North America and adjacent oceans during the last deglaciation: Boulder, Colorado, Geological Society of America, p. 425446.

Laabs, B.J., and Munroe, J.S., 2008, Glacial and pluvial records of the Angel Lake glaciation in northeastern Nevada and inferences of latest Pleistocene climate, Geological Society of America 2008 annual meeting: Geological Society of America Abstracts with Programs, v. 40, , no. 6, p. 147.

Laabs, B.J.C., Marchetti, D.W., Munroe, J.S., Refsnider, K.A., Gosse, J.C., Lips, E.W., Becker, R.A., Mickelson, D.M., and Singer, B.S., 2011, Chronology of latest Pleistocene mountain glaciation in the western Wasatch Mountains, Utah, USA: Quaternary Research, v. 76, p. 272-284.

Laabs, B.J.C., Munroe, J.S., Best, L.C., and Caffee, M.W., 2013, Timing of the last glaciation and subsequent deglaciation in the Ruby Mountains, Great Basin, U.S.A.: Earth and Planetary Science Letters, v. 361, p. 16-25.

Lillquist, K.D., 1994, Late Quaternary Lake Franklin— Lacustrine chronology, coastal geomorphology, and hydro-isostatic deflection in Ruby Valley and northern Butte Valley, Nevada: Salt Lake City, University of Utah, Ph.D. dissertation, $185 \mathrm{p}$.

Lines, G.C., 1979, Hydrology and surface morphology of the Bonneville Salt Flats and Pilot Valley playa, Utah: U.S. Geological Survey Water-Supply Paper 2057, 107 p.
Ludwig, K.R., 2003: User's manual for Isoplot 3.00, a geochronological toolkit for Microsoft Excel: Berkeley, California, Berkeley Geochronology Center Special Publication 4, $70 \mathrm{p}$.

Lyle, M., Heusser, L., Ravelo, C., Yamamoto, M., Barron, J., Diffenbaugh, N.S., Herbert, T., and Andreasen, D., 2012, Out of the tropics-The Pacific, Great Basin lakes, and late Pleistocene water cycle in the western United States: Science, v. 337, p. 1,629-1,633.

Mason, J.L., and Kipp, K.L., Jr., 1989, Hydrology of the Bonneville Salt Flats, northwestern Utah, and simulation of ground-water flow and solute transport in the shallow-brine aquifer: U.S. Geological Survey Professional Paper 1585, $108 \mathrm{p}$.

Matsubara, Y., and Howard, A.D., 2009, A spatially explicit model of runoff, evaporation, and lake extent-Application to modern and late Pleistocene lakes in the Great Basin region, Western United States: Water Resources Research, v. 45, p. W06425.

Mayo, A.L., and Tingey, D., 2014, Closed-basin freshwaterbrine groundwater interface and interactions-Pilot Valley, Utah-Nevada: Geological Society of America Abstracts with Programs, v. 46, no. 6, p. 409.

Mifflin, M.D., and Wheat, M.M., 1979, Pluvial lakes and estimated pluvial climates of Nevada: Reno, University of Nevada, Bulletin 94, 57 p.

Miller, D.M., 1990, Geologic map of the Crater Island SW quadrangle, Box Elder County, Utah: Utah Geological and Mineral Survey Map 129.

Miller, D.M., and Jordan, T.E., 1990: Geologic map of the Crater Island quadrangle, Box Elder County, Utah: Utah Geological and Mineral Survey Map 128.

Miller, D.M., and Lush, A.P., 1981: Preliminary geologic map of the Pilot Peak and adjacent quadrangles, Elko County, Nevada, and Box Elder County, Utah: U.S. Geological Survey Open-File Report 81-658, 1 map.

Munroe, J.S., and Laabs, B.J., 2013a: Latest Pleistocene history of pluvial Lake Franklin, northeastern Nevada, USA: Geological Society of America Bulletin, v. 125, p. 322-342.

Munroe, J.S., and Laabs, B.J., 2013b: Temporal correspondence between pluvial lake highstands in the southwestern US and Heinrich Event 1: Journal of Quaternary Science, v. 28, p. 49-58.

Munroe, J.S., and Laabs, B.J.C., 2009, A 7000-year lacustrine record from Angel Lake, Nevada: American Geophysical Union, Fall Meeting 2009. 
Munroe, J.S., and Laabs, B.J.C., 2011: New investigations of Pleistocene glacial and pluvial records in northeastern Nevada: Geological Society of America Field Guide 21, p. 1-25.

Munroe, J.S., Laabs, B.J.C., Shakun, J.D., Singer, B.S., Mickelson, D.M., Refsnider, K.A., and Caffee, M.W., 2006, Latest Pleistocene advance of alpine glaciers in the southwestern Uinta Mountains, Utah, USA-Evidence for the influence of local moisture sources: Geology, v. 34, p. 841-844.

Munroe, J.S., and Mickelson, D.M., 2002: Last Glacial Maximum equilibrium-line altitudes and paleoclimate, northern Uinta Mountains, Utah, U.S.A.: Journal of Glaciology, v. 48, p. 257-266.

Murchison, S.B., 1989, Fluctuation history of Great Salt Lake, Utah, during the last 13,000 years: Salt Lake City, University of Utah, Ph.D. dissertation.

Nelson, S.T., Wood, M.J., Mayo, A.L., Tingey, D.G., and Eggett, D., 2005, Shoreline tufa and tufaglomerate from Pleistocene Lake Bonneville, Utah, USA-Stable isotopic and mineralogical records of lake conditions, processes, and climate: Journal of Quaternary Science, v. 20, no. 1, p. 3-19.

Osborn, G., and Bevis, K., 2001, Glaciation in the Great Basin of the Western United States: Quaternary Science Reviews, v. 20 , no. 13 , p. $1,377-1,410$.

Oviatt, C.G., 1997, Lake Bonneville fluctuations and global climate change: Geology, v. 25, p. 155-158.

Oviatt, C.G., 2014, The Gilbert episode in the Great Salt Lake basin, Utah: Salt Lake City, Utah Geological Survey Miscellaneous Publication 14-3, 20 p.

Oviatt, C.G., 2015, Chronology of Lake Bonneville, 30,000 to 10,000 yr B.P.: Quaternary Science Reviews, v. 110, p. $166-171$.

Oviatt, C.G., Madsen, D.B., and Schmitt, D.N., 2003, Late Pleistocene and early Holocene rivers and wetlands in the Bonneville Basin of western North America: Quaternary Research, v. 60, p. 200-210.

Oviatt, C.G., Thompson, R.S., Kaufman, D.S., Bright, J., and Forester, R.M., 1999, Reinterpretation of the Burmester core, Bonneville Basin, Utah: Quaternary Research, v. 52, p. $180-184$.

Personius, S.F., and Scott, W.E., 1992, Surficial geologic map of the Sale Lake City segment and parts of adjacent segments of the Wasatch Fault Zone, Davis, Salt Lake, and Utah Counties, Utah: U.S. Geological Survey Miscellaneous Investigations Series Map I-2106, scale 1:50,000.
Plummer, M.A., and Phillips, F.M., 2003, A 2-D numerical model of snow/ice energy balance and ice flow for paleoclimatic interpretation of glacial geomorphic features: Quaternary Science Reviews, v. 22, p. 1,389-1,406.

Reheis, M.C., 1999, Extent of Pleistocene lakes in the western Great Basin: U.S. Geological Survey Miscellaneous Field Investigations Map MF-2323.

Reheis, M.C., Adams, K.D., Oviatt, C.G., and Bacon, S.N., 2014, Pluvial lakes in the Great Basin of the western United States-A view from the outcrop: Quaternary Science Reviews, v. 97, p. 33-57.

Reinemann, S.A., Porinchu, D.F., Bloom, A.M., Mark, B.G., and Box, J.E., 2009, A multi-proxy paleolimnological reconstruction of Holocene climate conditions in the Great Basin, United States: Quaternary Research, v. 72, p. 347358.

Rhode, D., Madsen, D.B., and Jones, K.T., 2006, Antiquity of early Holocene small-seed consumption and processing at Danger Cave: Antiquity, v. 80, p. 328-339.

Rhodes, E.J., Bronk Ramsey, C., Outram, C., Batt, C., Willis, L., Dockrill, S., and Bond, J., 2003, Bayesian methods applied to the interpretation of multiple OSL datesHigh precision sediment ages from Old Scatness Brock excavations, Shetland Isles: Quaternary Science Reviews, v. 22, p. 1,231-1,244.

Richmond, G., 1964, Glaciation of Little Cottonwood and Bells Canyons, Wasatch Mountains, Utah: U.S. Geological Survey Professional Paper 454-D, p. D1-D41.

Richmond, G.M., 1986, Stratigraphy and correlation of glacial deposits of the Rocky Mountains, the Colorado Plateau and the ranges of the Great Basin-Quaternary glaciations in the Northern Hemisphere: Quaternary Science Reviews, v. 5, p. 99-127.

Russell, I.C., 1885, Geological history of Lake Lahontan, a Quaternary lake of northwestern Nevada: U.S. Geological Survey Monograph 11, 288 p.

Scott, W.E., and Shroba, R.R., 1985, Surficial geologic map of an area along the Wasatch Fault Zone in the Salt Lake Valley, Utah: U.S. Geological Survey Open File Report 85-448, 19 p.

Sharp, R.P., 1938, Pleistocene glaciation in the RubyEast Humboldt Range, northeastern Nevada: Journal of Geomorphology, v. 1, p. 296-323.

Simpson, J.H., 1876, Report of explorations across the Great Basin of the Territory of Utah for a direct wagon-route from Camp Floyd to Genoa, in Carson Valley, in 1859: Engineer Department, U.S. Army, Washington, D.C. 
South, J.V., McBride, J., Mayo, A., Tingey, D.G., and Rey, K.A., 2014, Imaging the margins of Pleistocene lake deposits with high-resolution seismic reflection in the eastern Basin and Range-Pilot Valley, Utah (USA): Geological Society of America Abstracts with Programs, v. 46 , no. 6 , p. 410.

Thompson, R.S., 1992, Late Quaternary environments in Ruby Valley, Nevada: Quaternary Research, v. 37, p. 1-15.
Wayne, W.J., 1984, Glacial chronology of the Ruby Mountains-East Humboldt Range, Nevada: Quaternary Research, v. 21, p. 286-303.

Zdanowicz, C.M., Zielinski, G.A., and Germani, M.S., 1999, Mount Mazama eruption - Calendrical age verified and atmospheric impact assessed: Geology, v. 27, p. 621-624. 


\title{
Trip 2.-Tectonics, Climate, and Paleogeomorphology of the Green River Formation
}

\author{
By M. Elliot Smith ${ }^{1}$ and Jennifer J. Scott ${ }^{2}$
}

\section{Introduction and Trip Overview}

The Eocene Green River Formation is one of the world's foremost archives of lacustrine strata, and has been the subject of more than 2,000 stratigraphic and sedimentologic investigations. It represents one of the most continuous available records of climate-sensitive facies at an ice-free time of global warmth. This field trip explores the effects of tectonic activity, climate variability, and paleogeomorphology on the sedimentary facies and stratigraphic packaging of the Green River Formation in the Bridger subbasin of the Greater Green River Basin of Wyoming.

For nearly 100 years (Sears and Bradley, 1924; Bradley, 1929, 1964; Culbertson, 1961; Eugster and Hardie, 1975; Grande, 1984; Roehler, 1993; Carroll and Bohacs, 1999; Bohacs and others, 2000; Smith and others, 2014a), the controls on the deposition of the lacustrine oil shales, evaporite deposits, as well as the exceptional preservation of vertebrate and invertebrate fossils, have been long debated. The Green River Formation also has stimulated considerable interest because of its rich endowment of economic resources. Its potential to generate oil via retort of organic-rich mudstone has been recognized since at least 1916, when Federal Naval Oil Shale Reserves were designated by Woodrow Wilson in Colorado and Utah. However, it remains unclear how much of this resource (if any) will be commercially exploited, or whether the environmental consequences of its use would outweigh the benefits. Although very rich, Green River Formation oil shale generally is too thermally immature to act as a conventional petroleum source rock across most of its area, except in the northern Uinta basin. There, oil generated from the lower Green River Formation accounted for approximately 30 million barrels of production in 2014 (Utah Division of Oil, Gas, and Mining, 2015).

The other main economic resource of the Green River Formation is soda ash, which is mined primarily in the form of trona (Burnside and Culbertson, 1979; Wiig and others, 1995). Trona deposits in the Bridger basin of Wyoming represent the single largest soda ash deposit in the world, with more than 17 million metric tons of production in 2013 (U.S. Geological Survey, 2015).

\footnotetext{
${ }^{1}$ School of Earth Sciences and Environmental Sustainability, Northern Arizona University.

${ }^{2}$ Department of Earth Sciences, Mount Royal University, Calgary.
}

The Green River Formation accumulated between about 53 and 45 million years ago (Ma) in a series of tectonic basins that resulted from the about 75-45 Ma growth of basementcored "Laramide" uplifts that partitioned a Cretaceous broad retroarc foreland basin east of the Cordilleran hinterland (Dickinson and others, 1988; Smith and others, 2008) (fig. 2.1). These uplifts caused flexural subsidence in the lake basins, which largely controlled the thicknesses of the sedimentary units and contributed to the formation of several interbasinal sills between lake basins (Beck and others, 1988).

Through this field trip, we will explore the effects of the different controls on the Green River Formation in Wyoming using evidence at various scales, from trace fossils to alluvial fans. We integrate a wide array of recent findings, including radioisotopic dating, basin-scale correlation, facies analysis, ichnofossils, and geochemistry.

\section{The Wilkins Peak Member, Green River Formation, Bridger subbasin, Wyoming}

The Wilkins Peak Member is the evaporative core of the Green River Formation in the Greater Green River Basin (GGRB) (fig. 2.2) and coincides in time with the second half of the Early Eocene Climatic Optimum, which exhibited the warmest global temperatures of the Cenozoic (Zachos and others, 2008; Hyland and Sheldon, 2013; Smith and others, 2014a) (fig. 2.3). Wilkins Peak Member strata in the center of the Bridger subbasin of the GGRB are strikingly cyclic, and record abrupt expansions and contractions of Lake Gosiute that resulted in alternating deposition of bedded evaporites, oil shale, eulittoral micrites, and basin interior alluvial strata. Wilkins Peak Member strata deposited adjacent to the Uinta Uplift differ from other parts of the GGRB in both composition and paleobiology. Lake expansions along the Uinta margin are recorded predominantly by calcium carbonate $\left(\mathrm{CaCO}_{3}\right)$-rich mudstones and sandstones that record oxygenated conditions, whereas fanglomerate and alluvial plain deposits dominate during lake contractions. Conglomerate clast compositions record diachronous syndepositional unroofing of Phanerozoic strata from the crest of the Uinta Uplift that resulted in a series of west-stepping alluvial fans along its margin with which the Green River Formation interfingers. 


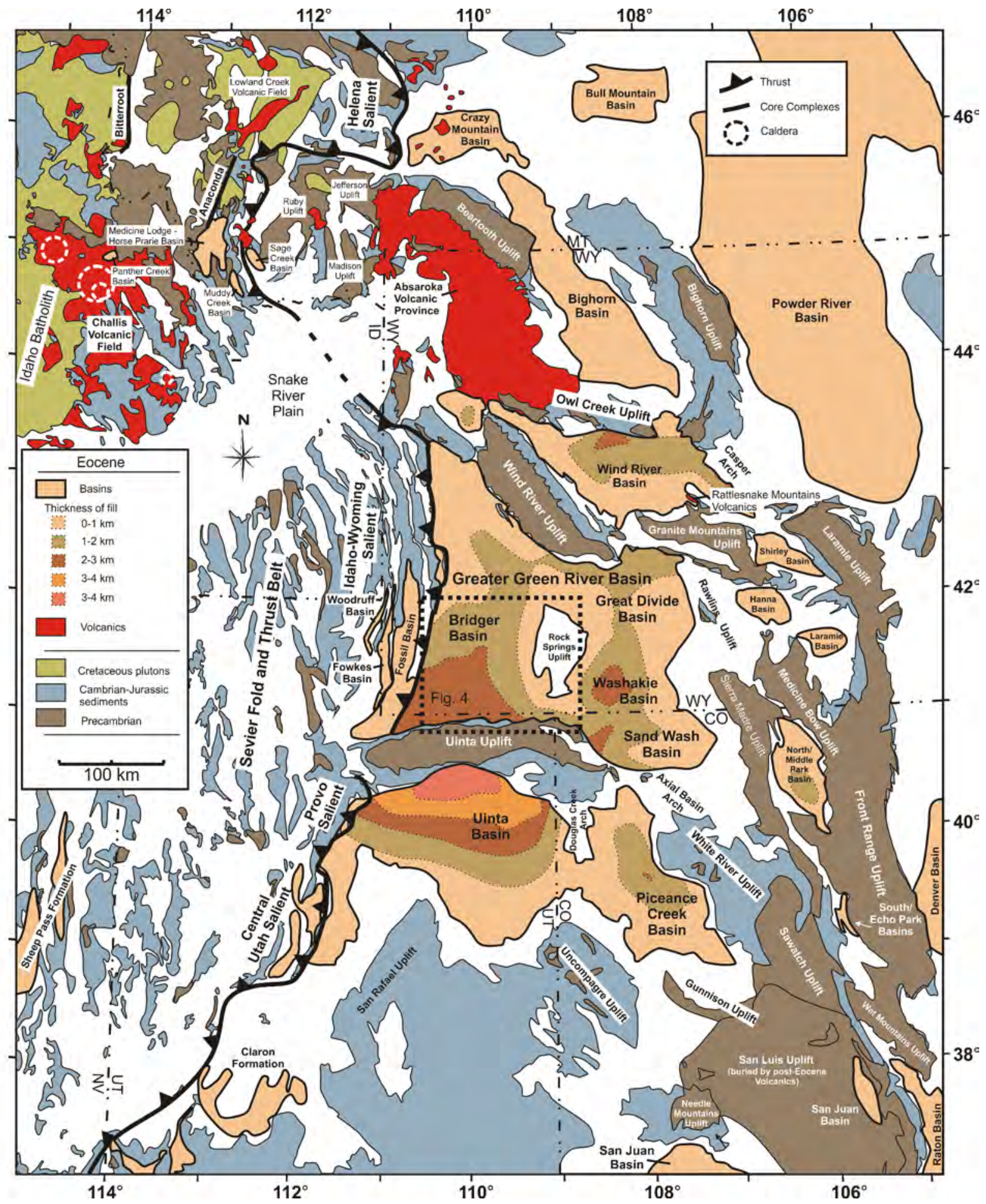

Figure 2.1. Map showing location of Eocene basins and basin-bounding uplifts within the broader Cordilleran orogeny, showing the thickness of Eocene strata; modified from Smith and others (2008). 


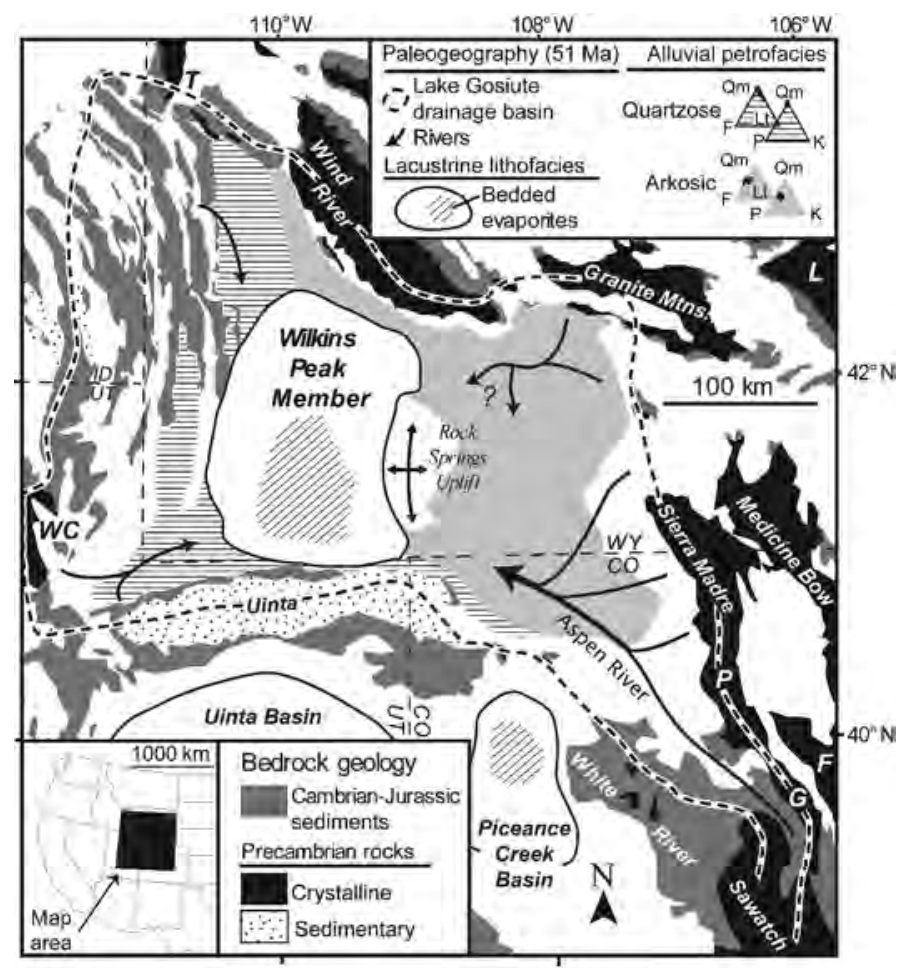

Figure. 2.2. Map of the Eocene paleocatchment for the Greater Green River Basin, and areas of alluvial, lacustrine, and evaporite accumulation within it (modified from Smith and others, 2014a). Abbreviations for tectonic uplifts: $T$, Teton-Gros Ventre; $P$, Park, G, Gore; F, Front Range; WC; Wasatch Culmination.

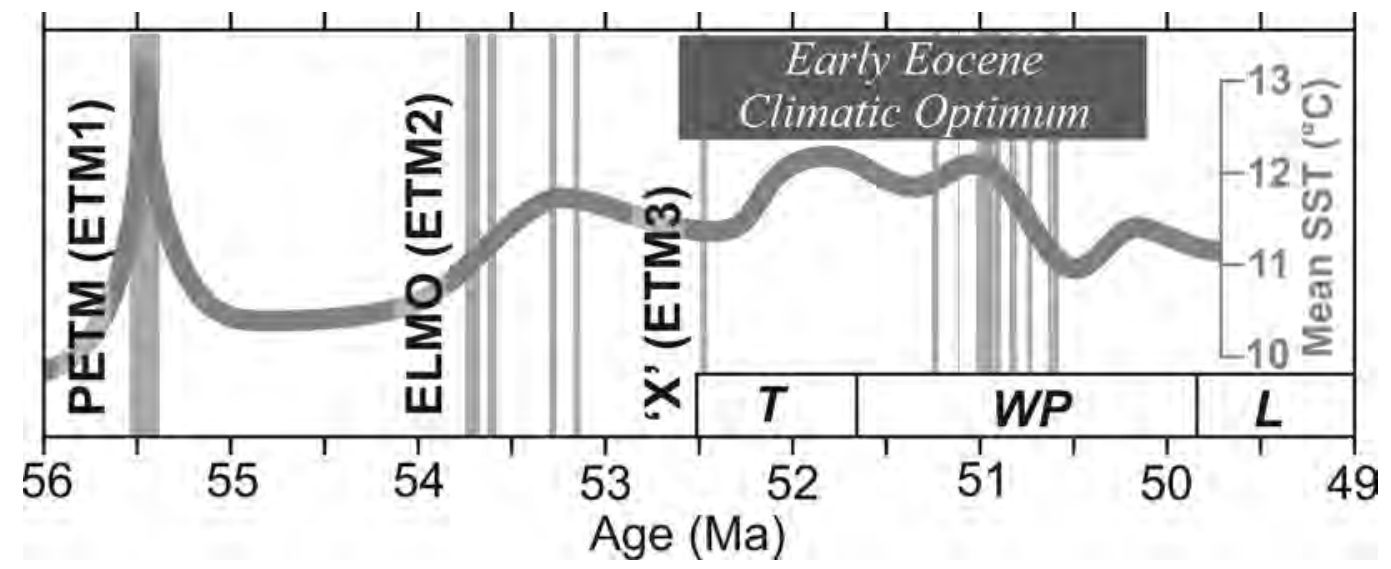

Figure 2.3. Early Eocene carbon isotope events (gray bars, Zachos and others, 2010; Smith and others, 2014a) and their relation to long-term global temperature variations including the Early Eocene Climatic Optimum (Zachos and others, 2008). Green River Formation: T, Tipton Member; WP, Wilkins Peak Member; L, Laney Member.

Interbedded with Uinta Uplift-marginal strata are numerous carbonate buildups composed of tufa and travertine that likely record point sources of calcium- and silicon-rich fluids to the lake and surrounding environments.

This 3-day field trip focuses on the strata of the Wilkins Peak Member in the Bridger subbasin (fig. 2.4). The first day includes a tour of its classic, beautifully exposed basin-center facies in Firehole and Sage Creek Canyons, where participants observe oil shale, evaporites, and alluvial facies, and examine their cyclic packaging. The second day focuses on newly discovered lake marginal carbonate and fanglomerate facies and the carbonate buildups contained within these facies. Finally, on the third day, the trip examines growth strata within the Wilkins Peak Member at Slate Creek on the western edge of the GGRB, which record the growth and subsequent cessation of contractile deformation along the leading edge of the Sevier fold and thrust belt. 


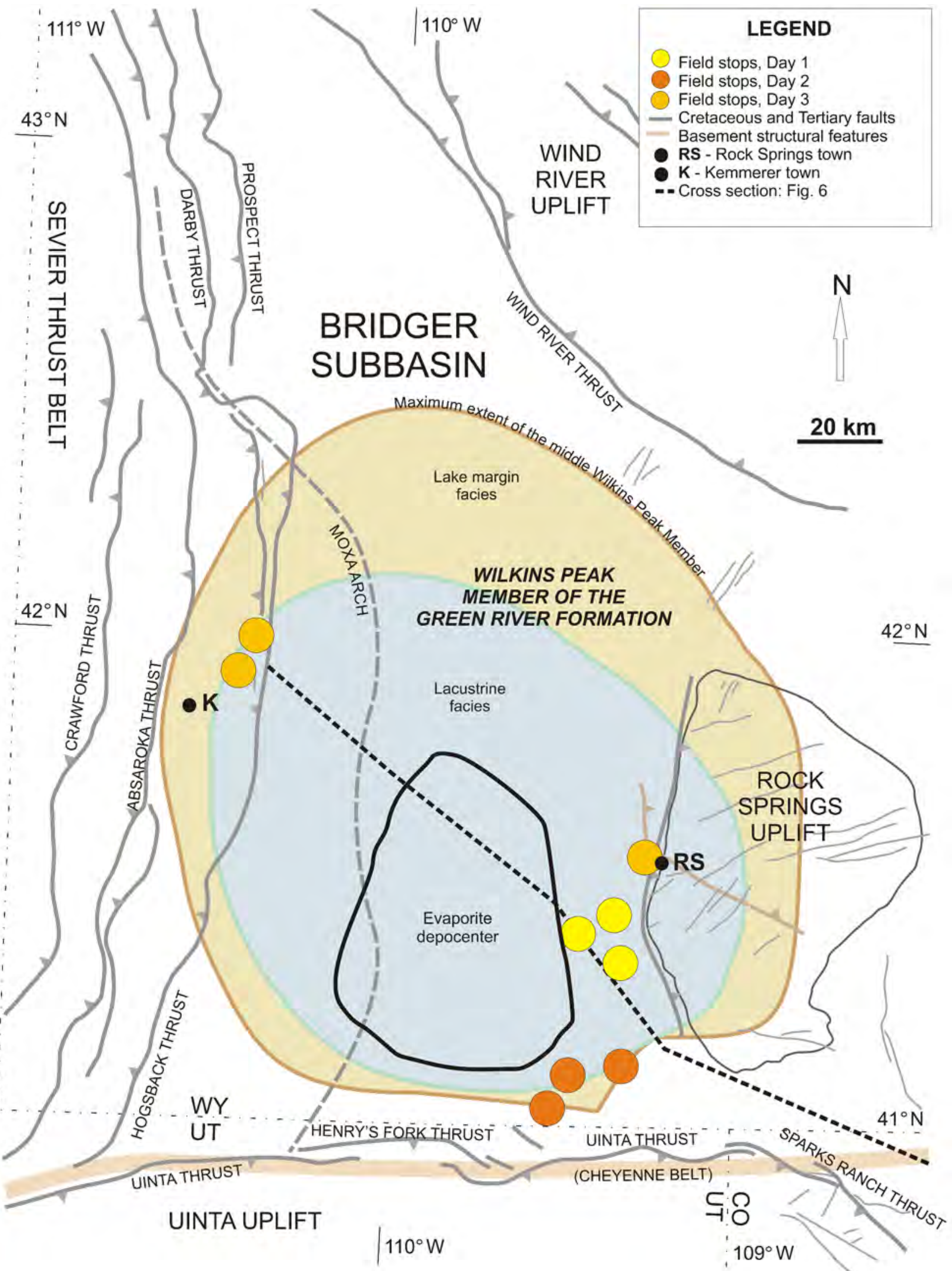

Figure 2.4. Map of field trip locations showing the extent of middle Wilkins Peak Member and its lithofacies belts in relation to regional tectonic elements. 


\section{DAY 1. The Basin Interior}

\section{Stop 1. Middle Firehole Canyon Overview-Eocene Stratigraphy of the Greater Green River Basin}

\section{Stop Summary}

We begin the trip with an overview of a beautifully exposed section through the Green River Formation (GRF) on the eastern basin center of the Bridger subbasin of the GGRB (fig. 2.5). Post-Oligocene canyon incision along the western edge of the Rock Springs Uplift has exposed the westward-dipping Eocene section in which the lacustrine GRF strata overlies alluvial facies of the "main body" of the Wasatch Formation (fig. 2.6).

\section{Basinal and Tectonic Context}

We stand on the western side of the Rock Springs Uplift in the center of the GGRB, which was an actively uplifting basement-connected structure during the Paleogene. Movement on the uplift following the deposition of the
Eocene GRF led to westward regional dipping of up to about $12^{\circ}$, most steeply along the eastern Bridger basin. Although Green River Formation strata are absent from the crest of the Rock Springs Uplift, strata of both the Wasatch and Green River Formations thicken westward into the Bridger subbasin.

The Precambrian-cored Uinta Uplift is visible to the south, and formed the southern margin of the basin in the Eocene. This uplift separated Lake Gosiute from Lake Uinta in the Uinta Basin of Utah. Uplift of the Uintas began in the latest Cretaceous (Maastrichtian) and continued until at least the middle Eocene.

\section{Stratigraphy and Environments}

The red-colored alluvial facies of the Main Body of the Wasatch Formation fill the valley floor, and include lenticular, isolated yellow-to-purple sandstone bodies that represent fluvial channels through a well-drained floodplain of red siliciclastic mudstone (fig.2.5A). These through-going alluvial environments dominated the GGRB prior to the expansion of the Green River Formation lake system.

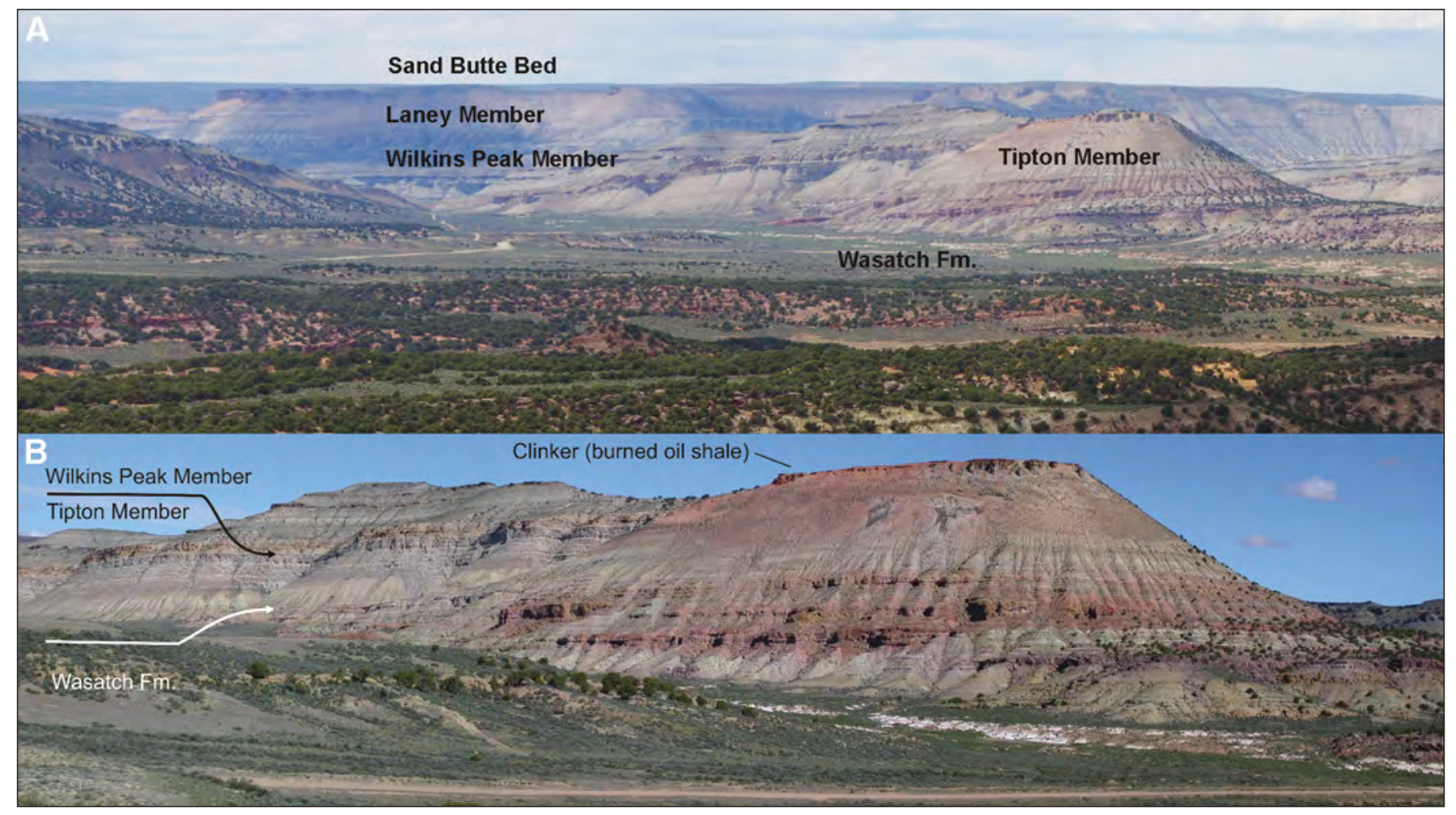

Figure 2.5. (A) Photograph of the Wasatch and Green River formations at Little Firehold Canyon overlook. (B) Photograph showing the Wasatch Formation overlain by the Tipton Member, with "kliner", and the Wilkins Peak Members of the Green River Formation at Middle Firehole Canyon. (Photographs by (A) J.J. Scott, Mount Royal University, taken in June 2013; (B) M.E. Smith, Northern University, taken in June 2003.) 


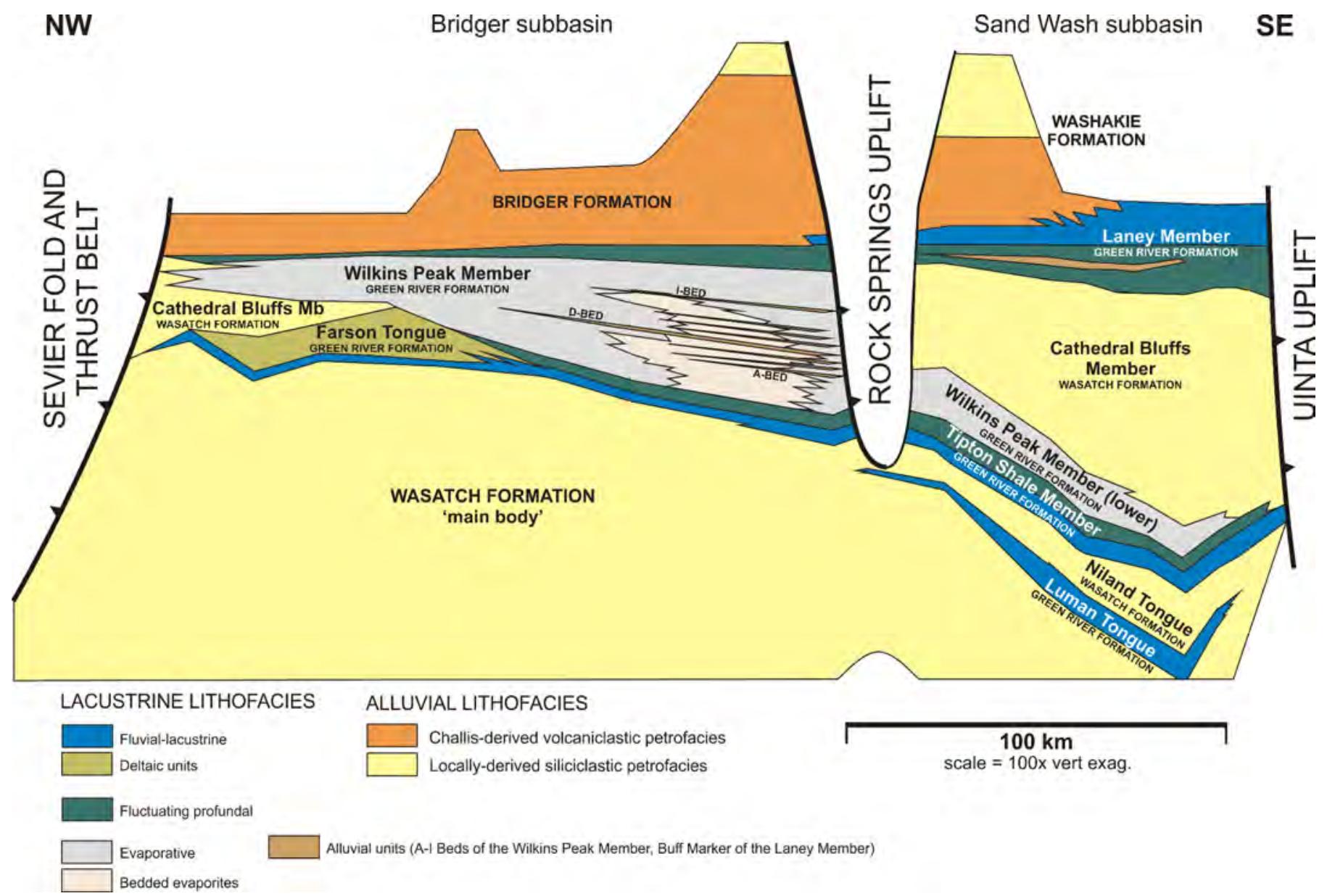

Figure 2.6. Generalized lithostratigraphy of Eocene strata in the Greater Green River Basin along the northwest-to-southeast cross section shown in figure 2.4 .

The first extensive lakebeds in this area comprise the Tipton Member of the GRF, which can be broken into the lower, buffcolored, silty Schegg's Bed, and the upper, dark brown-colored oil shale of the Rife Bed. The orange-colored outcrop is oil shale "klinker," formed when lightning ignited organic-rich Tipton Member oil shale (fig. 2.5B). Moving upwards from the klinker, the sharp transition to from orange to white strata signifies the lower Wilkins Peak Member, which is composed of calcitic and dolomitic carbonates and evaporites. Although the carbonates weather white, they may be internally grayish white (typically calcite-rich), light brownish white (typically dolomite-rich), light brown (some organics preserved), or dark brown to black (organic-rich).

Near the top of the outcrop north of Middle Firehole Canyon, we see the first of the arkosic sandstone units that comprise alluvial facies deposited during periods of low lake levels (fig. 2.5B). These beds were described and named sandstone-mudstone units A-I by Culbertson (1961), and record the advection of alluvium into the basin interior during extended periods of low lake level (compare Smith and others, 2014a). We will investigate two of these clastic units in detail as we continue through Firehole Canyon and Sage Creek Canyon (that is, “A-Bed” and "D-Bed”).

Across the Green River towards the west, the section begins at the fourth arkosic sandstone unit ("D-Bed") and continues through to the kerogen-rich LeClede Bed of the Laney Member, which represents the transition of Lake Gosiute to a balanced-fill lake type (fig. 2.5A). The uppermost reddishbuff sandstone buttes forming the top of the exposed section represent the Sand Butte Bed of the Laney Member. This volcaniclastic-rich sandstone was derived from the Challis volcanic field, and eventually filled Lake Gosiute from the north, first forming turbidites, and then deltaic foresets and massive load structures. 
Stop 2. The "A-Bed" Arkosic Sandstone of the Wilkins Peak Member, Firehole Canyon

\section{Stop Summary}

Along the drive into Firehole Canyon, we pass through the Wasatch Formation, orange klinker of the Tipton Shale (Rife Bed), and lacustrine carbonates of the lower Wilkins Peak Member, and stop at the first arkosic sandstone unit in the Wilkins Peak. Culbertson (1961) described nine main arkosic units in the eastern Bridger subbasin and named them units A-I. These alluvial units intercalated with similarly thick intervals of lacustrine carbonate shales and evaporates at the 5-30-m scale. Available geochronology indicates that this oscillation closely approximates 100 kyr. eccentricity (fig. 2.7; Fischer and Roberts, 1991; Aswasereelert and others, 2013; Smith and others, 2014a). We will discuss the potential reasons for these stratigraphic relationships, and consider climate and landscape processes as controls on the fill of the underfilled lake-type basin.

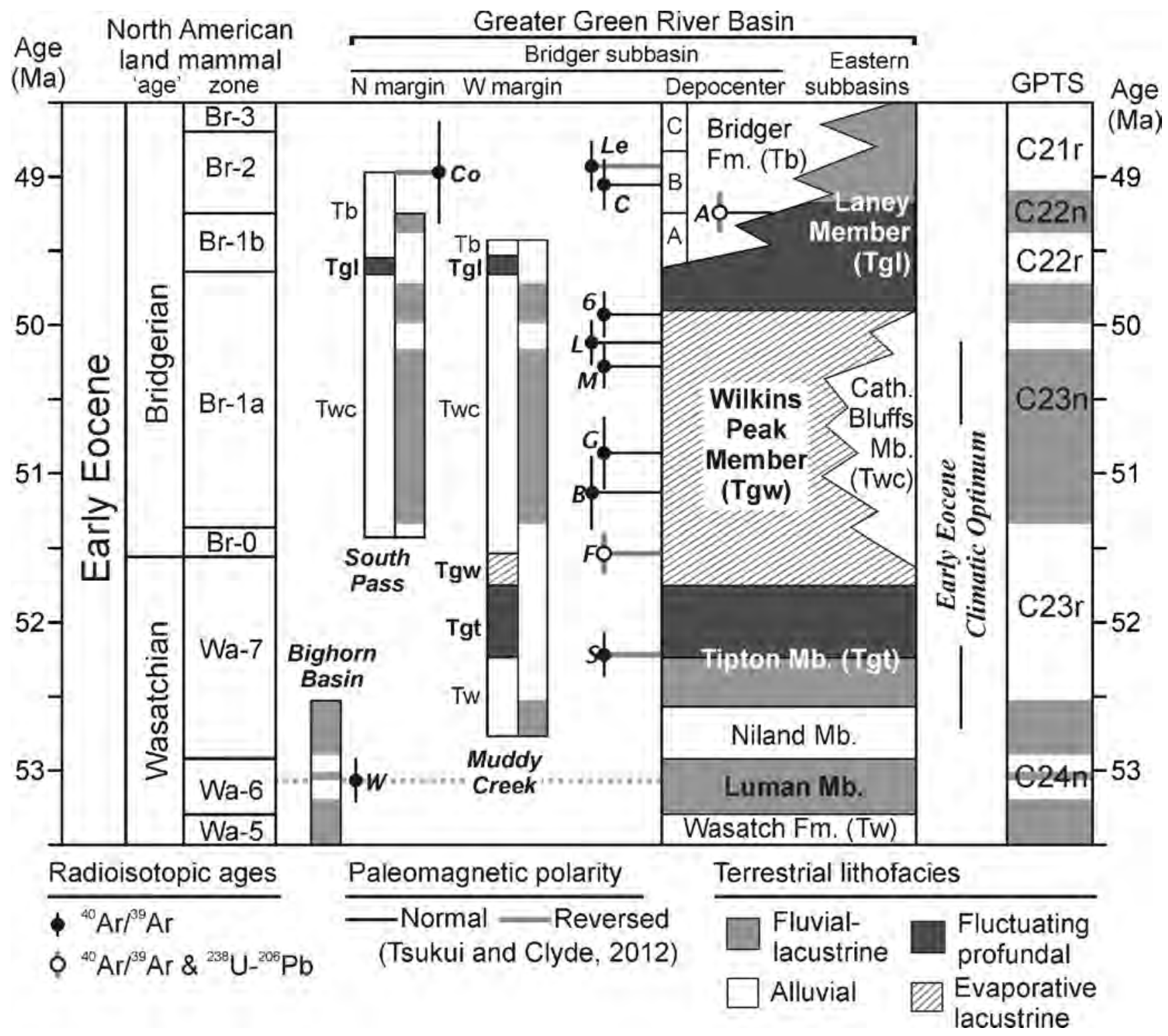

Figure 2.7. Geochronology of Early Eocene lacustrine and alluvial strata, showing radioisotopic ages (Smith and others, 2008, 2010), ash bed paleomagnetic polarity (Tsukui and Clyde, 2012), terrestrial biostratigraphy (Zonneveld and others, 2000; Woodburne and others, 2009), and magnetostratigraphy in the Greater Green River Basin (Clyde and others, 1997, 2001). Green River Formation subdivisions are shown in bold type. Radioisotopic ages for the Willwood ash $(M)$, Schegg's tuff $(S)$, Firehole tuff $(F)$, Boar tuff $(B)$, Gray tuff $(G)$, Main tuff $(M)$, Layered tuff $(L)$, Sixth tuff $(6)$, and Analcite tuff $(A)$, Church Butte tuff $(C)$, Continental tuff $($ Co), and Leavitt Creek tuff $($ Le) are depicted with fully propagated $2 \sigma$ uncertainties, and are calculated relative to the 28.201 Ma age for Fish Canyon rhyolite sanidine (Kuiper and others, 2008) using $\lambda\left({ }^{40} \mathrm{~K}\right)$ values and uncertainties of Min and others (2000). ${ }^{40} \mathrm{Ar} /{ }^{39} \mathrm{Ar}$ and U-Pb ages are error-weighted means of ${ }^{40} \mathrm{Ar} /{ }^{39} \mathrm{Ar}$ and U-Pb ages (compare Smith and others, 2010). Modified from Smith and others (2014a). 


\section{Basinal and Tectonic Context}

Carbonate oil shales, shallow lacustrine facies, and evaporites dominated the western side of the Rock Springs Uplift throughout the deposition of the Wilkins Peak Member. On the eastern side of the Rock Springs Uplift, arkosic alluvial facies of the Cathedral Bluffs Tongue of the Wasatch Formation formed nearly the entire middle GRF package, with lacustrine facies represented only by the lower Wilkins Peak in the Sand Wash and Washakie subbasins (fig. 2.6). The alluvial beds (A-I) are interpreted to be basinward incursions of this alluvial system (the "Aspen River”), which derived most of its sediments from basement cored uplifts to the east and south (fig. 2.3). This is supported by their arkosic composition, which is distinct from the quartzose sands derived from the Uinta Uplift, and by the presence of predominantly west-directed paleoflow indicators in fluvial facies of the alluvial intervals.

\section{Stratigraphy, Sedimentary Environments, and Trace Fossils}

The Wilkins Peak Member was deposited in an underfilled lake-type basin in which sediment and water input was less than the potential accommodation (Carroll and Bohacs, 1999; Bohacs and others, 2000). Its lithofacies have been the subject of several sedimentologic investigations (Eugster and Hardie, 1975; Smoot, 1983; Roehler, 1993; Pietras and Carroll, 2006), and can be grouped into alluvial and lacustrine macroassociations (Smith and others, 2014a; table 2.1), which are intercalated at the 5-30-m scale.

Because the lacustrine-alluvial alternation appears to follow orbital eccentricity, Smith and others (2014a) proposed that the lacustrine intervals that record repeated lake inundation and desiccation represent greater hydrologic variance than alluvial beds (fig. 2.8). The maxima in hydrologic variance likely tracks eccentricity maxima when insolation variations caused by precession cycles would have been most pronounced. These compositionally distinct associations sharply contrast in outcrop, with predominantly whiteweathering carbonates representing lacustrine facies and brown arkosic sandstones and siliciclastic mudstones representing the alluvial facies (fig. 2.9).
Table 2.1. Wilkins Peak Member lithofacies: Central Bridger subbasin. [See Smith and others, 2014a for more details]

\begin{tabular}{|c|c|c|}
\hline \multicolumn{2}{|r|}{$\begin{array}{c}\text { Lithofacies Association } \\
\text { Lithofacies }\end{array}$} & Sedimentology \\
\hline \multicolumn{3}{|c|}{ L) Lacustrine Macroassociation } \\
\hline \multirow[t]{5}{*}{ i) } & Palustrine Associationa & Mudstone Facies ${ }^{\mathrm{b}}$ \\
\hline & $\begin{array}{l}\text { 1. Wavy-bedded } \\
\text { carbonate siltstone- } \\
\text { sandstone }\end{array}$ & Subfacies DM1-2 and EL-1 ${ }^{\mathrm{c}}$ \\
\hline & 2. Brecciated to & Subfacies DM3 and EL1-2c, \\
\hline & massive carbonate & Brecciated Carbonate \\
\hline & mudstone-siltstone & Mudstone-Siltstonea \\
\hline \multirow[t]{7}{*}{ i) } & Littoral Association & \\
\hline & 1. Calcareous & Flat-Pebble Conglomerate Facies ${ }^{b}$, \\
\hline & intraclastic & Subfacies SF5 \\
\hline & conglomerate & Intraclastic Conglomeratea \\
\hline & 2. Calcareous & Lime Sandstone Facies ${ }^{\mathrm{b}}$, \\
\hline & sandstone & Subfacies SF1-4c \\
\hline & $\begin{array}{l}\text { 3. Stromatolitic, } \\
\text { laminated carbonate } \\
\text { mudstone }\end{array}$ & Facies SF (part) ${ }^{c}$ \\
\hline \multirow[t]{4}{*}{ iii) } & Salt-Pan Associationa & \\
\hline & $\begin{array}{l}\text { 1. Displacive } \\
\text { evaporites }\end{array}$ & Subfacies SM2c \\
\hline & 2. Bedded evaporites & Trona-Halite Facies ${ }^{\mathrm{b}}$ \\
\hline & & Subfacies SMc \\
\hline \multirow[t]{4}{*}{ iv) } & \multicolumn{2}{|c|}{ Profundal-Sublittoral Associationa } \\
\hline & $\begin{array}{l}\text { 1. Massive carbonate } \\
\text { mudstone and } \\
\text { marlstone }\end{array}$ & Subfacies PL2 ${ }^{c}$ \\
\hline & 2. Laminated kerogen- & Oil Shale Facies ${ }^{\mathrm{b}}$ \\
\hline & $\begin{array}{l}\text { rich carbonate } \\
\text { mudstone and } \\
\text { marlstone }\end{array}$ & Subfacies PL1 ${ }^{c}$ \\
\hline
\end{tabular}

\begin{tabular}{|c|c|c|}
\hline \multicolumn{2}{|c|}{ A) Alluvial Macroassociation } & \multirow{3}{*}{$\begin{array}{l}\text { Siliciclastic Sandstone Facies }^{\mathrm{b}} \\
\text { Facies AS (part) }^{\mathrm{c}} \\
\text { Siliciclastic Sandstonea }\end{array}$} \\
\hline \multirow[t]{4}{*}{ i) } & \multirow[t]{2}{*}{ Fluvial Association } & \\
\hline & & \\
\hline & $\begin{array}{l}\text { 1. Trough cross- } \\
\text { stratified and planar } \\
\text { to ripple-laminated } \\
\text { sandstone }\end{array}$ & \\
\hline & $\begin{array}{l}\text { 2. 2. Drape-bedded } \\
\text { sandstone }\end{array}$ & \\
\hline \multirow[t]{3}{*}{ i) } & Distal-Overbank & Facies AS (part) ${ }^{c}$ \\
\hline & $\begin{array}{l}\text { 1. Climbing-rippled } \\
\text { and planar bedded } \\
\text { sandstone and } \\
\text { siltstone }\end{array}$ & Siliciclastic Sandstone (part) ${ }^{\mathrm{a}}$ \\
\hline & $\begin{array}{l}\text { 2. Massive to faintly- } \\
\text { bedded siltstone and } \\
\text { mudstone }\end{array}$ & Green-Brown Mudstone Siltstone \\
\hline
\end{tabular}

${ }^{a}$ Follows Pietras and Carroll (2006).

bEugster and Hardie (1975).

'Smoot (1983). 


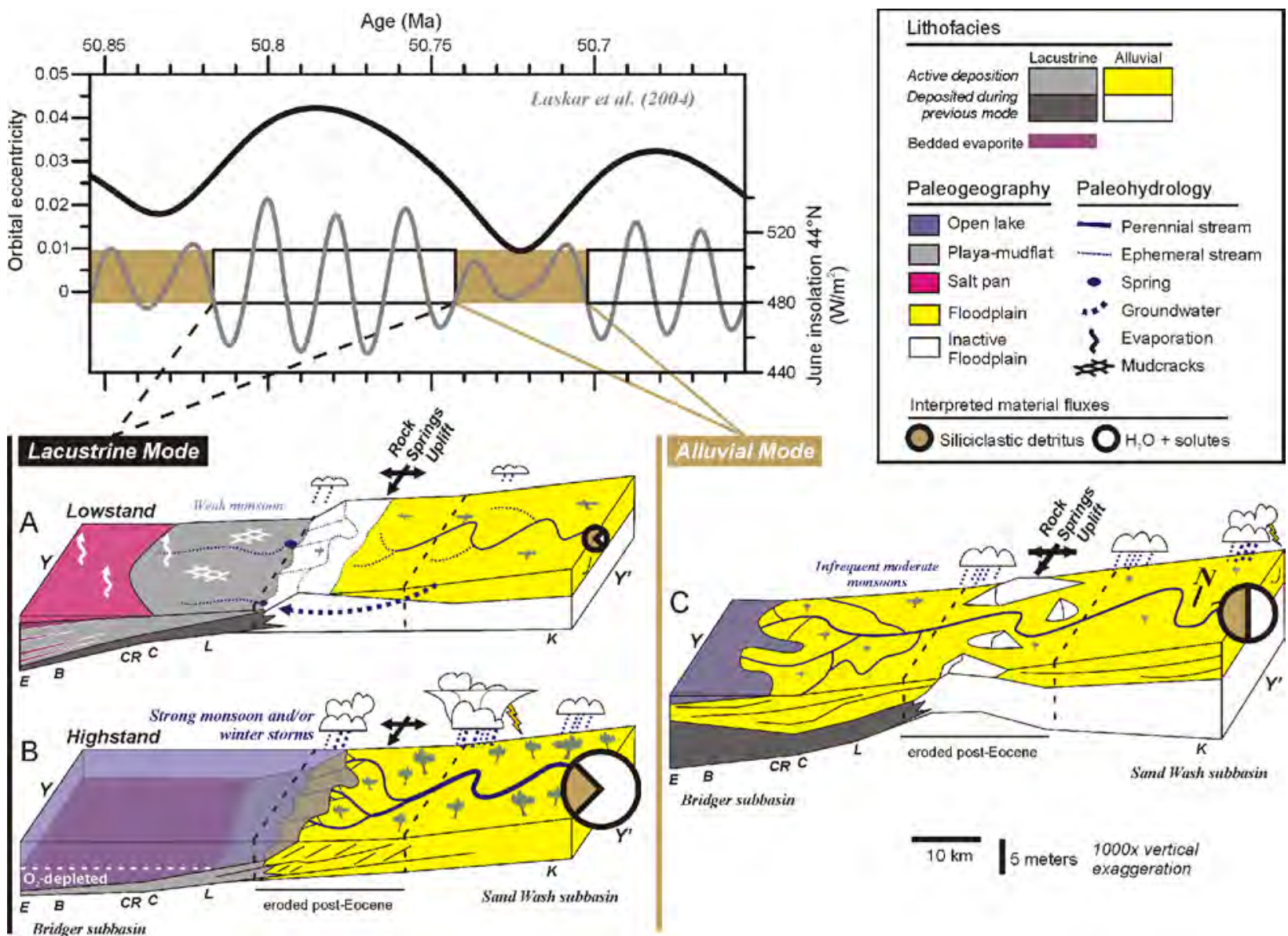

Figure 2.8. Tri-modal paleohydrology, sediment transport, and lithofacies accumulation models for observed strata to the east and west of the Rock Springs Uplift along the axis of the Aspen River, with oscillations between (A) lacustrine mode lowstand, (B) lacustrine mode highstand, and (C) alluvial mode graphically related to precession-modulated summer insolation resulting from two typical eccentricity cycles at $44^{\circ} \mathrm{N}$ (Laskar and others, 2004). These models accommodate measured stratal thicknesses, the absence of Aspen River-derived arkosic sandstone during lacustrine modes, and the absence of evaporites in the Bridger subbasin during alluvial modes. Modified from Smith and others (2014a). 


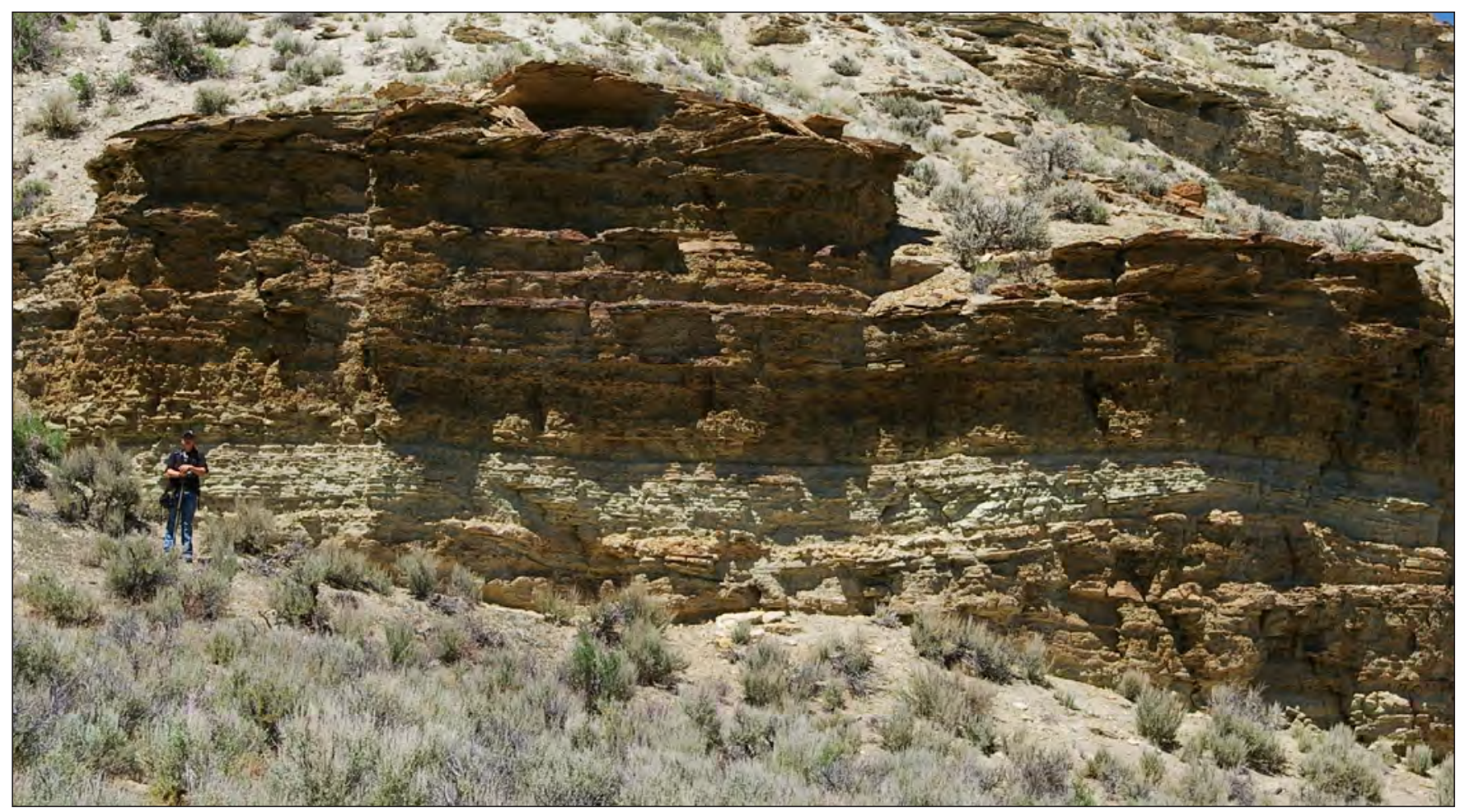

Figure 2.9. Photograph of sandstone-mudstone unit $A$ in Firehole Canyon. Note the orange weathering second tuff near the base of the slope. (Photograph by J.J. Scott, Mount Royal University, taken in June 2008.)

Alluvial units often are divided into two or three shallowing upwards packages, which could be considered parasequences bounded above and below by lacustrine facies (fig. 2.10). The lowermost parts of parasequences typically preserve evidence of very fine-grained clastic sediment input into the evaporitic lake, represented by marls. In other examples, sandstone-filled channel incisions cut into the underlying lacustrine carbonates. Individual parasequences show progressively landward facies in the uppermost portions of the units, likely representing progradation of the clastics towards the basin center. Above the A-Bed sandstone, relatively deep water lacustrine carbonates overlie a thin orange-colored laminar stromatolite bed, which formed on this transgressive surface of the lake and marks a return to lacustrine macroassociation lithofacies.

\section{Trace Fossils}

Trace fossils form only low-diversity assemblages in the shallow-water evaporitic carbonate lake facies, comprising mainly simple trails such as the ichnogenus
Helminthoidichnites (Scott and Smith, 2015). Trace fossils are rare within the saline lake facies of the underfilled Wilkins Peak Member, but a slightly higher diversity assemblage (e.g., Planolites) is present within the carbonate lakebeds that are sandwiched between the alluvial clastic facies of the parasequences. This higher diversity is likely due to the input of relatively fresh water to an otherwise inhospitable environment for most burrowing organisms.

In contrast, the clastic alluvial facies preserve a moderateto-high diversity assemblage of trace fossils produced by air-breathing terrestrial invertebrates and vertebrates (Scott, 2010; Scott and Smith, 2015). In the A-Bed outcrops at Firehole Canyon, some of the most characteristic trace fossils include shorebird footprints and invertebrate surface tunnels and burrows (fig. 2.11). Together with the sedimentology, traces support progradational stacking within the arkosic sandstone units in response to lake-level variations and (or) fluvial avulsion. 


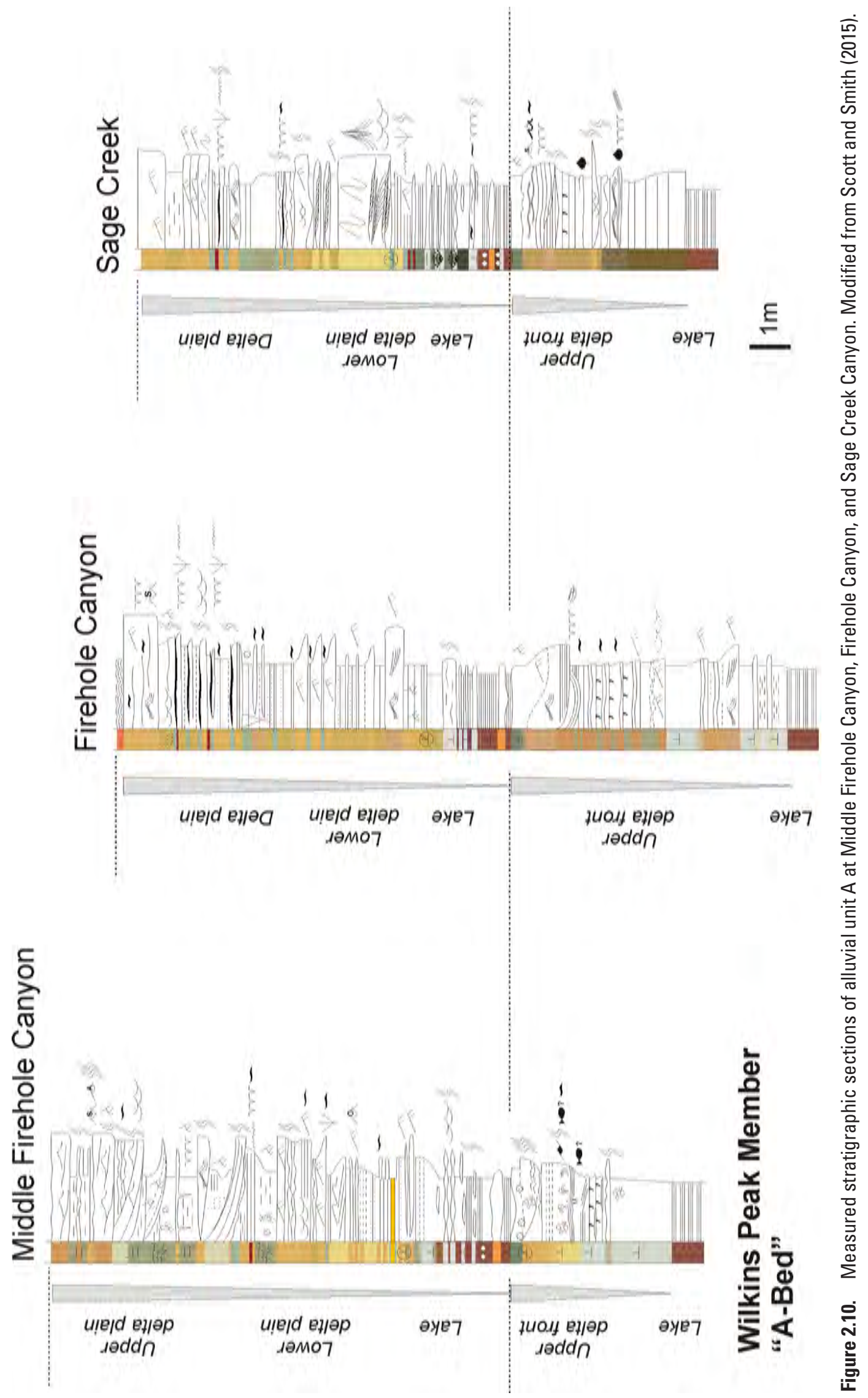



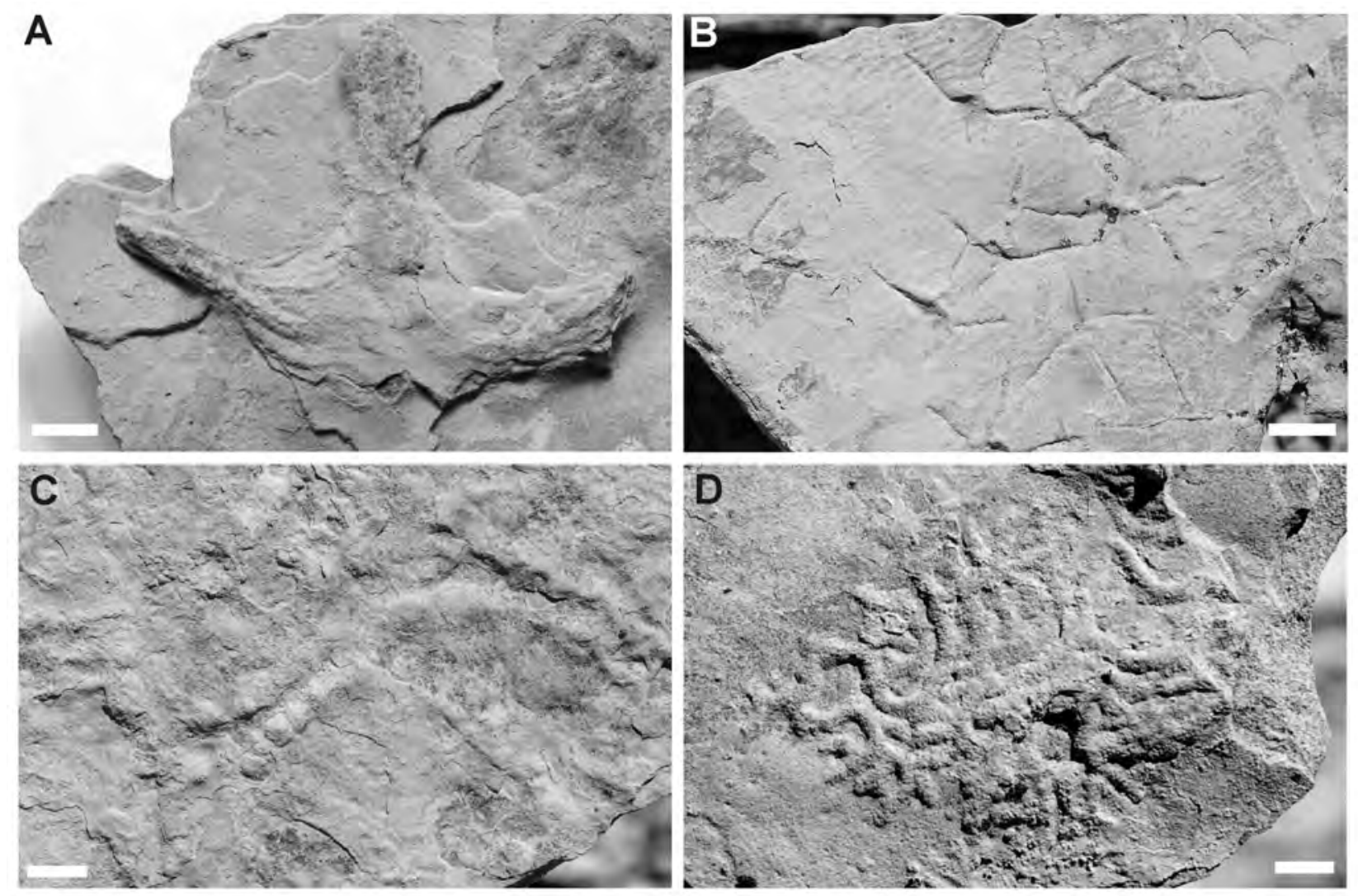

Figure 2.11. Photographs of trace fossils from alluvial clastic unit A at Firehole Canyon. Scale bars all 2 centimeters. (A) Cast of large goose-like bird footprint. (B) Several impressions of shorebird-like footprints. (C) Trackway of arthropod in soft substrate. (D) Multiple cross-cutting tunnels, probably produced by insect larvae. (Photographs by J.J. Scott, Mount Royal University, taken in June 2007.)

\section{Stop 3. The "D-Bed" Arkosic Sandstone of the Wilkins Peak Member, Firehole Canyon}

\section{Stop Summary}

The fourth of nine arkosic sandstone units is the thickest (about $25 \mathrm{~m}$ in Firehole Canyon) and most laterally extensive alluvial unit in the Bridger subbasin. It contains a wide variety of observable lithofacies, including well-developed lateral accretion surfaces and two interalluvial lakebeds that have elevated uranium and thorium concentrations. The evaporitic carbonates of the lacustrine interval that underlies the D-Bed clastic unit are some of the best exposed examples of bedded evaporites in the Wilkins Peak Member, which are made up of thin beds of trona pseuodomorphs.
Stratigraphy, Sedimentary Environments, and Trace Fossils

\section{Sedimentary Environments and Expression of the Lacustrine and Alluvial Modes}

Sedimentary facies in the D-Bed arkosic sandstone unit are similar to those of the A-Bed unit visited at Stop 2, and include both the lacustrine and alluvial modes (fig. 2.8). Additional facies to observe at this stop include: (1) bedded evaporites at the base of the outcrop; (2) low-gradient lateral and downstream accretion surfaces in sandstone, (3) mud plugs; (4) stromatolite rip-ups and green-weathering black marls; (5) meter-scale trough cross-stratification; (6) drape-bedded transgressive sandstone units (fig. 2.12); and (7) wave-rippled marls and desiccated carbonates of a flooded channel and transgressive eulittoral carbonate mudflats. 


\section{Stratigraphy and Stratigraphic Packaging}

Thin lakebeds enriched with uranium and thorium are present within the clastic alluvial units, and can be used to correlate the basin center alluvial units. The strongest gamma ray "spikes" from these uranium- and thorium-enriched beds are found in the lake-expansion beds contained within the alluvial units (fig. 2.12). These enriched beds were likely deposited when reducing lacustrine waters carrying uranium in solution became rapidly oxygenated, and (or) the $\mathrm{pH}$ of the lake decreased rapidly (Mott and Drever, 1983). Both scenarios can be explained by considering the impact of freshwater and sediment input from the alluvial systems to saline Lake Gosiute.

\section{Trace Fossils}

Trace fossils in the D-Bed helps to illustrate that the subunits "parasequences" within it became increasingly terrestrial and well drained in their upper portions (fig. 2.13). Lacustrine deposits contained with these dominantly alluvial units preserve vertically oriented and relatively large simple burrows that are uncommon in the saline lacustrine units of the typical Wilkins Peak lake carbonates. Meniscate backfilled burrows demonstrate that the upper parts of the parasequences were better drained. Overall, the diversity of trace fossils in these units is substantially higher than the diversity seen in other Wilkins Peak environments. Assemblages include insect tunnels, simple horizontal and vertical burrows, meniscate backfilled burrows, and mammal and bird footprints.

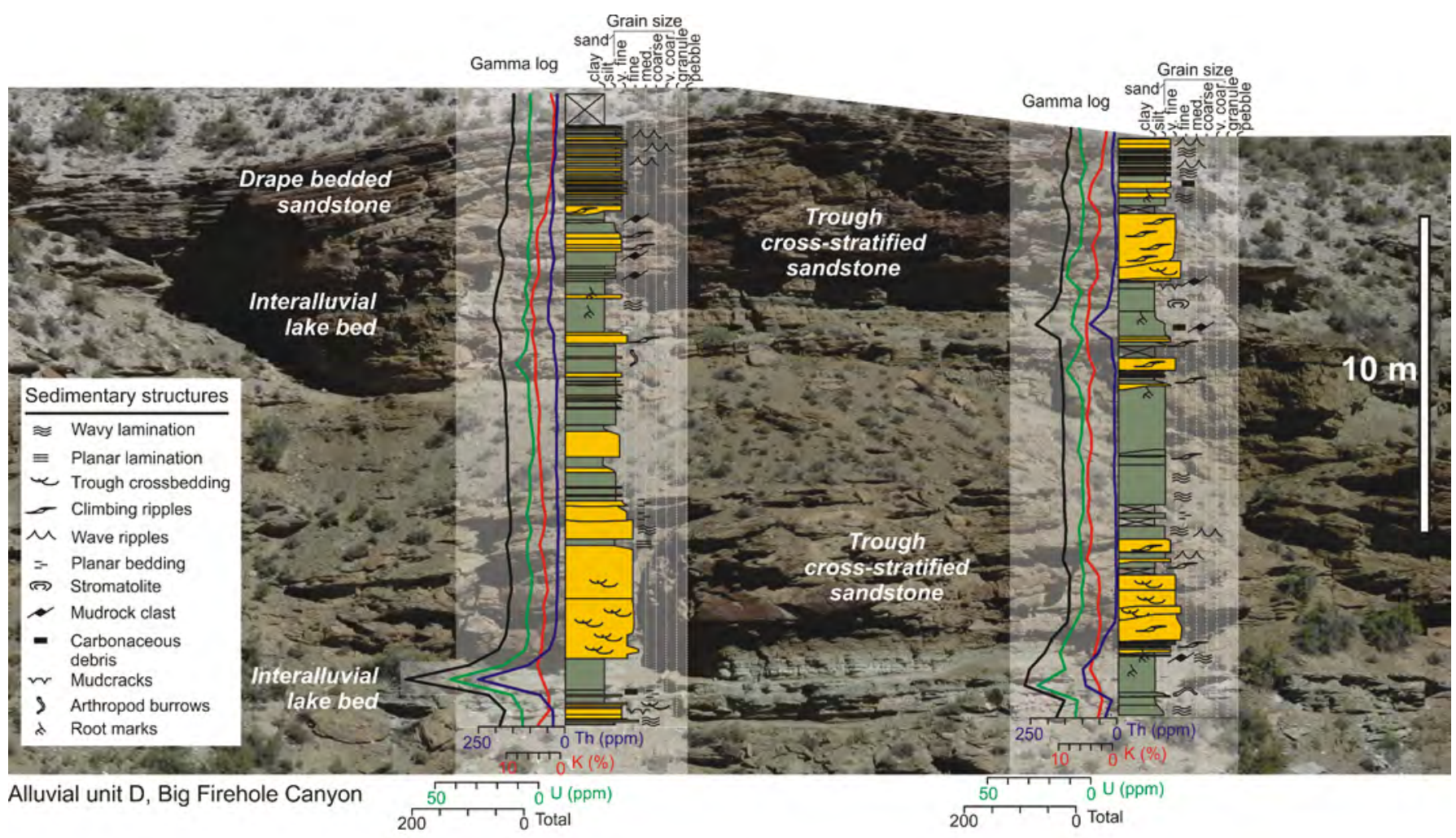

Figure 2.12. Photographic correlation of two measured stratigraphic sections and gamma logs of alluvial unit D at Firehole Canyon. (Photograph by M.E. Smith, Northern Arizona University, taken in June 2003.) 
Ephemeral freshwater body

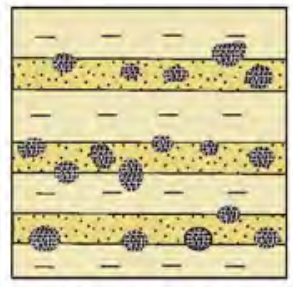

Standing water

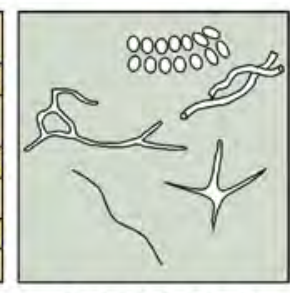

Desiccated pool
Lower delta-plain

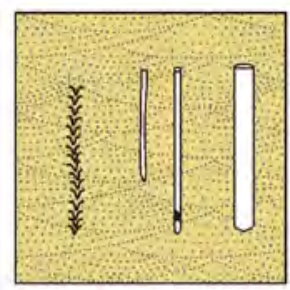

Unidirectional flow

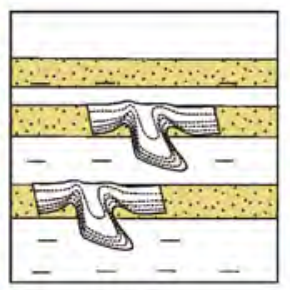

Mudflat
Fresh water lake

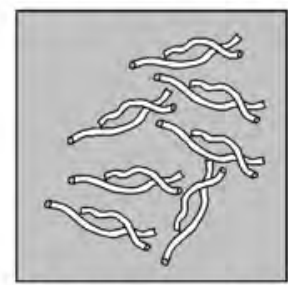

Proximal delta-front
Upper delta-plain

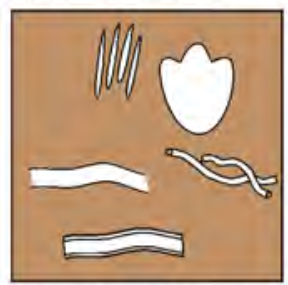

Abandoned channel

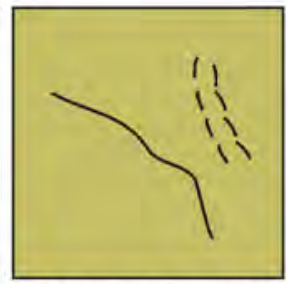

Short-lived wetting

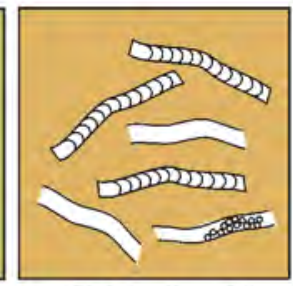

Moist subaerial

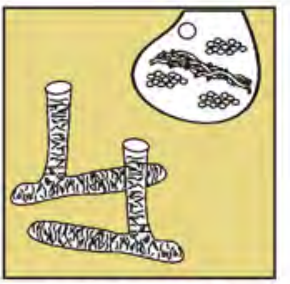

Drier subaerial

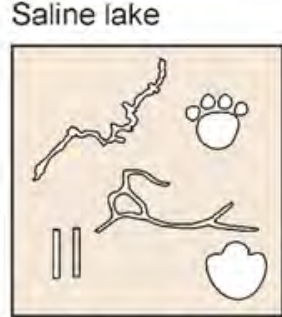

Saline mudflat

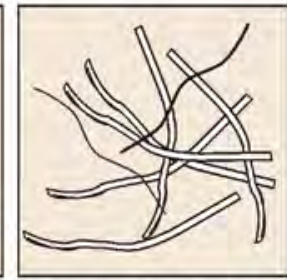

Shallow saline lake

\section{Ephemeral fresh} water body

Figure 2.13. Diagram showing idealized trace fossil assemblages from the basin center Wilkins Peak Member in the Greater Green River Basin, and their typical distribution in alluvial and carbonate lacustrine environments. Modified from Scott and Smith (2015).

\section{Stop 4. Overview of the Underfilled to Balanced Filled Transition in the Basin Interior}

\section{Stop Summary}

From the Firehole picnic grounds, the stunning view includes: (1) the middle and upper Wilkins Peak Member, including alluvial units E-I; (2) the sharp contact between the underfilled lake-type Wilkins Peak and the balanced fill lake-type LaClede Bed of the Laney Member; and (3) the butte-forming volcaniclastic Sand Butte Bed of the Laney Member (fig. 2.14).

\section{Discussion - Controls on Lake-Type Basins}

The lake-type model (Carroll and Bohacs, 1999) is based on the relationship between sediment and water input and the potential accommodation below the basin-bounding sill. If water and sediment are entirely contained with the basin, both solutes and sediments accumulate. This is the case for underfilled lake basins, which we see in evaporative strata of the Wilkins Peak Member. If the rate of sediment and water input to the basin is approximately equal to the rate of potential accommodation below the basin-bounding sill, the lake is typically larger in aerial extent and sedimentary package comprises proportionately more deep water facies. This is the case for balanced fill lake basins, which we see in the fluctuating profundal LaClede Bed of the Laney Member. The extremely sharp contact between the Wilkins Peak and LaClede Bed, seen clearly at this stop, suggests that something changed in the system quite rapidly. A sharp increase in the ${ }^{87} \mathrm{Sr} /{ }^{86} \mathrm{Sr}$ composition of carbonate and the abrupt reintroduction of fish fossils across the boundary suggests the capture of a stream that drained radiogenic Precambrian rocks exposed in Laramide uplifts to the east of the GGRB (Smith and others, 2014b). Volcaniclastic sandstone of the Sand Butte Bed represents extrabasinal sediment influx that would ultimately lead to the freshening and terminal infill of Lake Gosiute from northwest to southeast (fig. 2.15; Surdam and Stanley, 1980; Smith and others, 2008; Doebbert and others, 2010). 


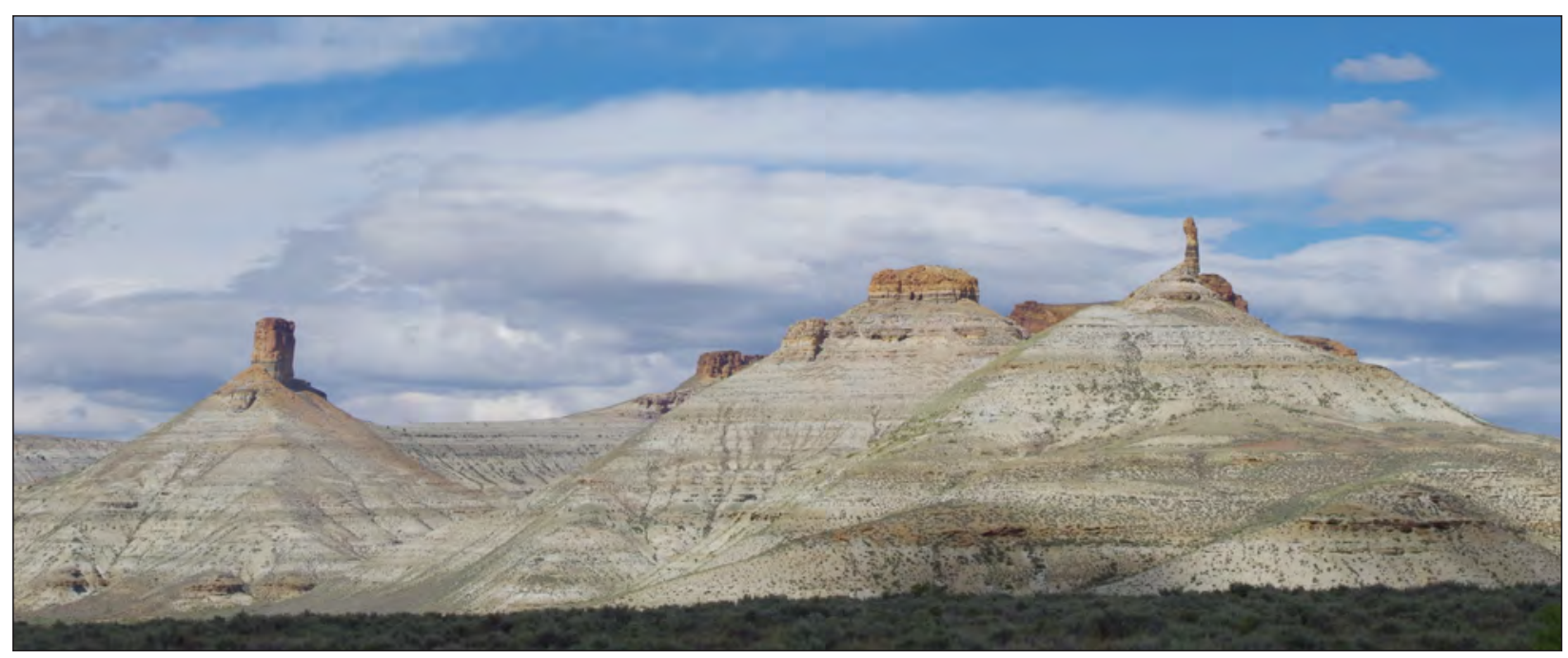

Figure 2.14. Photograph of the buttes capped by volcaniclastic sandstone of the Sand Butte Bed of the Laney Member. Brown-colored strata of the Laney Member of the Green River Formation overlie the grayish Wilkins Peak Member that makes up the lower two-thirds of the exposure. (Photograph by J.J. Scott, Mount Royal University, taken in June 2013.)
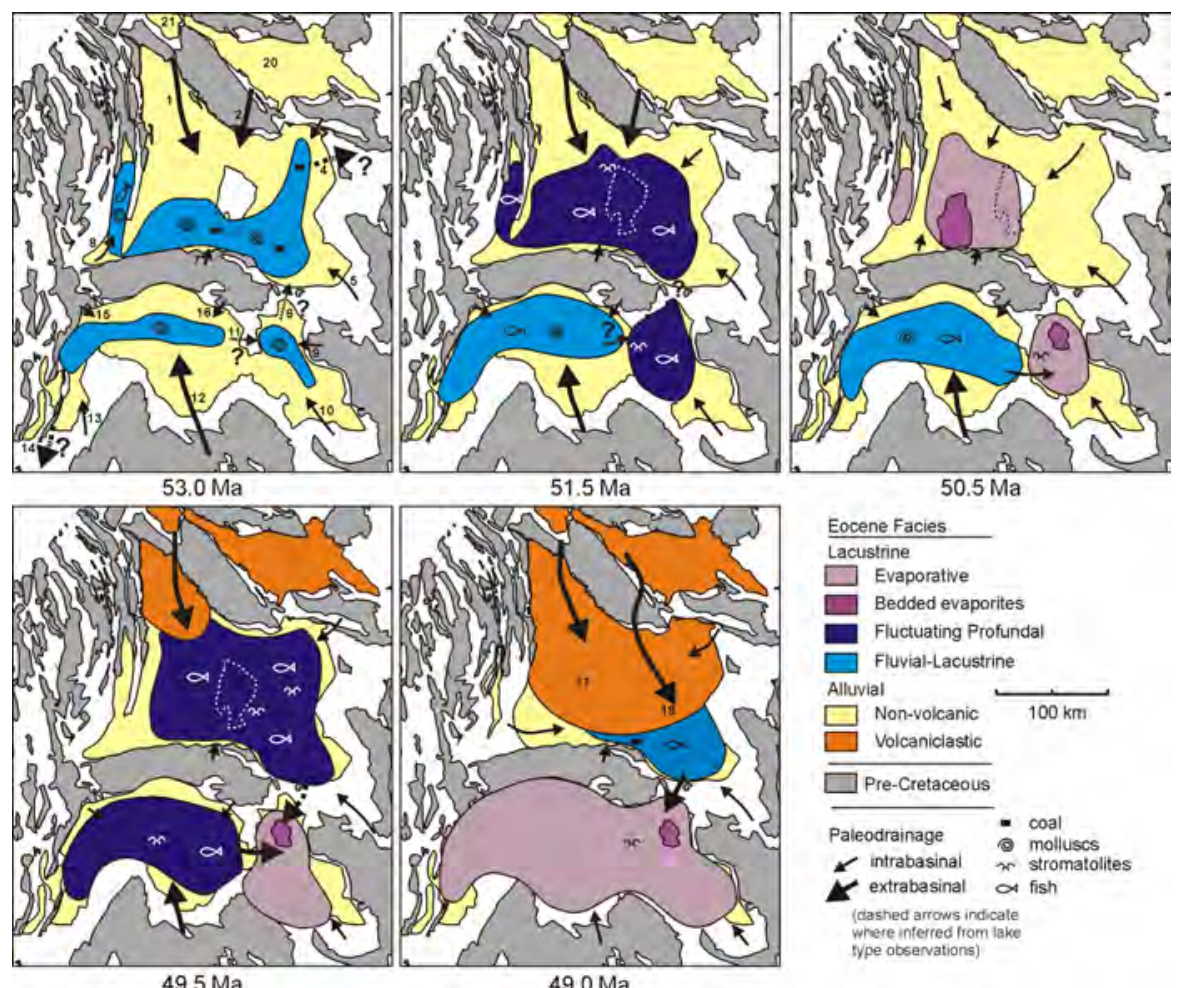

Figure 2.15. Synoptic paleogeographic maps of the Laramide broken foreland province showing the migration of lacustrine environments during early Eocene deposition of the Green River Formation. Modified from Smith and others (2008). 


\section{Stop 5. Closer to the Aspen River Clastic Source- Alluvial Unit A in Sage Creek Canyon}

\section{Stop Summary}

As we drive southeastward through Sage Creek Canyon, we are moving closer to the location where the Aspen River entered the Bridger subbasin between the Uinta Uplift and the southern end of the Rock Springs Uplift (fig. 2.2).

\section{Stratigraphy, Sedimentary Environments, and Trace Fossils}

The A-Bed sandstone is very comparable to the Firehole Canyon section and is clearly divided into two parasequences separated by a flooding surface and lacustrine facies (fig. 2.10). This exposure highlights a distinctive fluvial point bar succession that records the lateral migration and progressive deepening of the channel. Other facies include mud-filled channels that mark the uppermost portion of the lower parasequence and fluvial sandstones exhibit spectacular syndepositional soft sediment deformation in the lower part of the upper parasequence.

\section{DAY 2. Basin Peripheral Green River Formation Strata Adjacent to the Uinta Uplift}

\author{
Stop 6. The Pipeline Section
}

\section{Stop Summary}

At the southern basin periphery, the Luman, Tipton, and Wilkins Peak members of the Green River Formation are well exposed in the "Pipeline section" (fig. 2.16). These facies are distinctive from their basin interior equivalents due to their predominantly calcitic mineralogy and the presence of coarse-grained siliciclasic alluvium derived from the Uinta Uplift. The section includes diverse assemblages of terrestrial and lacustrine ichnofossils that correspond well with an integrated ichnology/lake-type basin model (Scott and others, 2012).

\section{Basinal and Tectonic Context}

The basin peripheral Green River Formation exposed along the Bridger subbasin's southern margin records both high accommodation due to flexure and the close proximity of

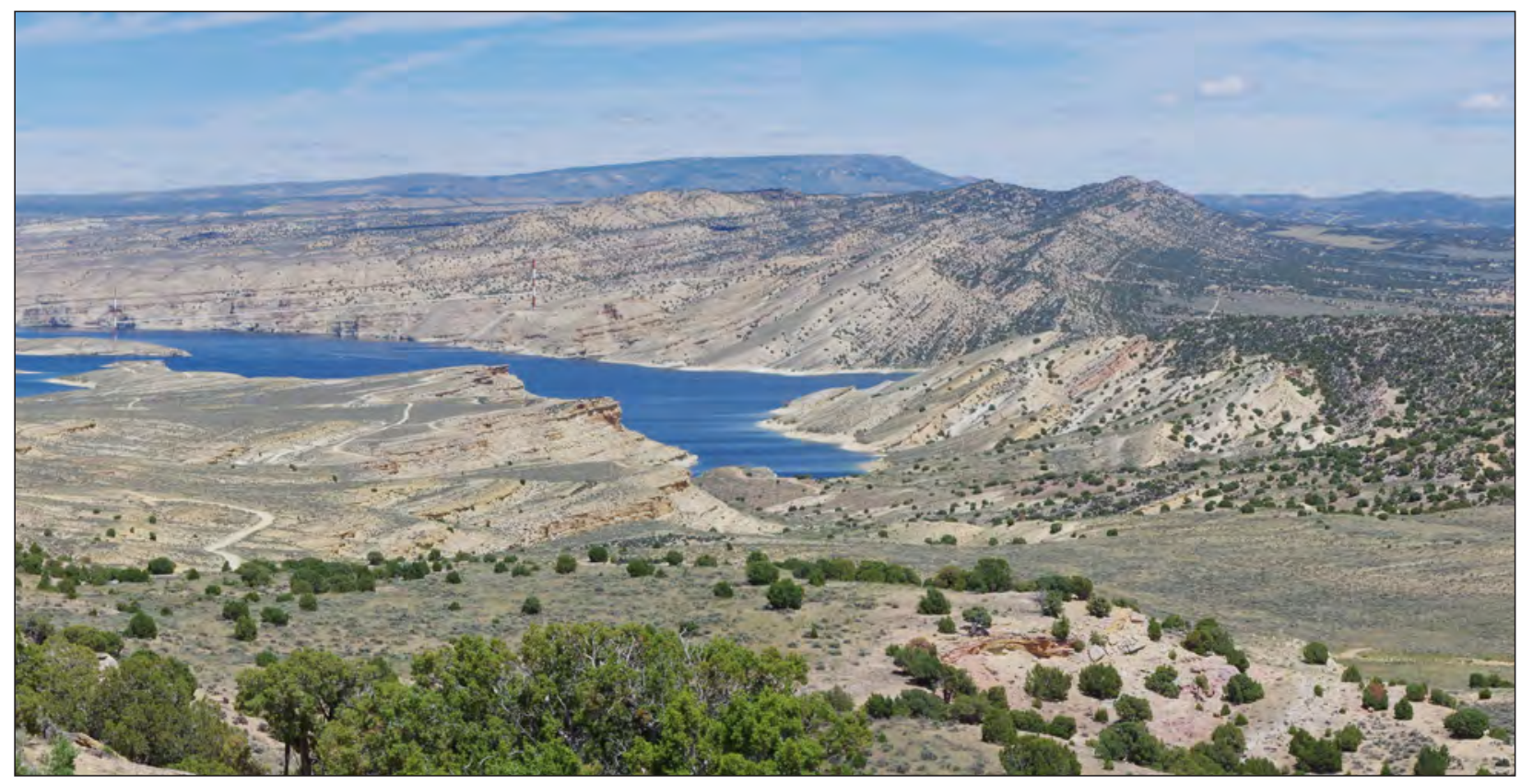

Figure 2.16. Photograph of the "Pipeline section", which exposes the entire Green River Formation adjacent to the Uinta Uplift. Strata are folded into a monocline above the blind Henrys Fork reverse fault. (Photograph by J.J. Scott, Mount Royal University, taken in June 2014.) 
streams that originated from the Uinta Uplift. These strata have been tilted into a monocline atop the blind Henrys Fork thrust subsequent to deposition of the Green River Formation. The Henrys Fork thrust surfaces several kilometers to the west near Manila, Utah.

\section{Stratigraphy, Sedimentary Environments, and Trace Fossils}

\section{Stratigraphy and Sedimentary Environments}

Green River Formation strata at the Pipeline section consist of two predominant types: (1) calcitic lacustrine mudstones and sandstones (fig. 2.17); and (2) quartzose siliciclastic alluvium derived from the Uinta Uplift (fig. 2.18). These lithofacies are arranged at a similar scale and have been correlated to the lacustrine-alluvial beds in the basin interior, suggesting that they record basin-wide changes in lake level and sediment advection by fluvial processes. Using tuffs, gamma-ray signatures, and the lacustrine expansion units within the Pipeline section, the quartzose fan-dominated sediments of the southern margin can be correlated to the basin center sandstone units seen on Day 1.

Coarse alluvial fan deposits east of the Pipeline section (fig. 2.19) constitute the Canyon Road Fan, which was the dominant alluvial point source between Dutch John and Manila during Wilkins Peak deposition. Conglomerate clast compositions record the coincident unroofing of Phanerozoic strata from the crest of the uplift, with an increasing abundance of clasts derived from older formations found upsection.
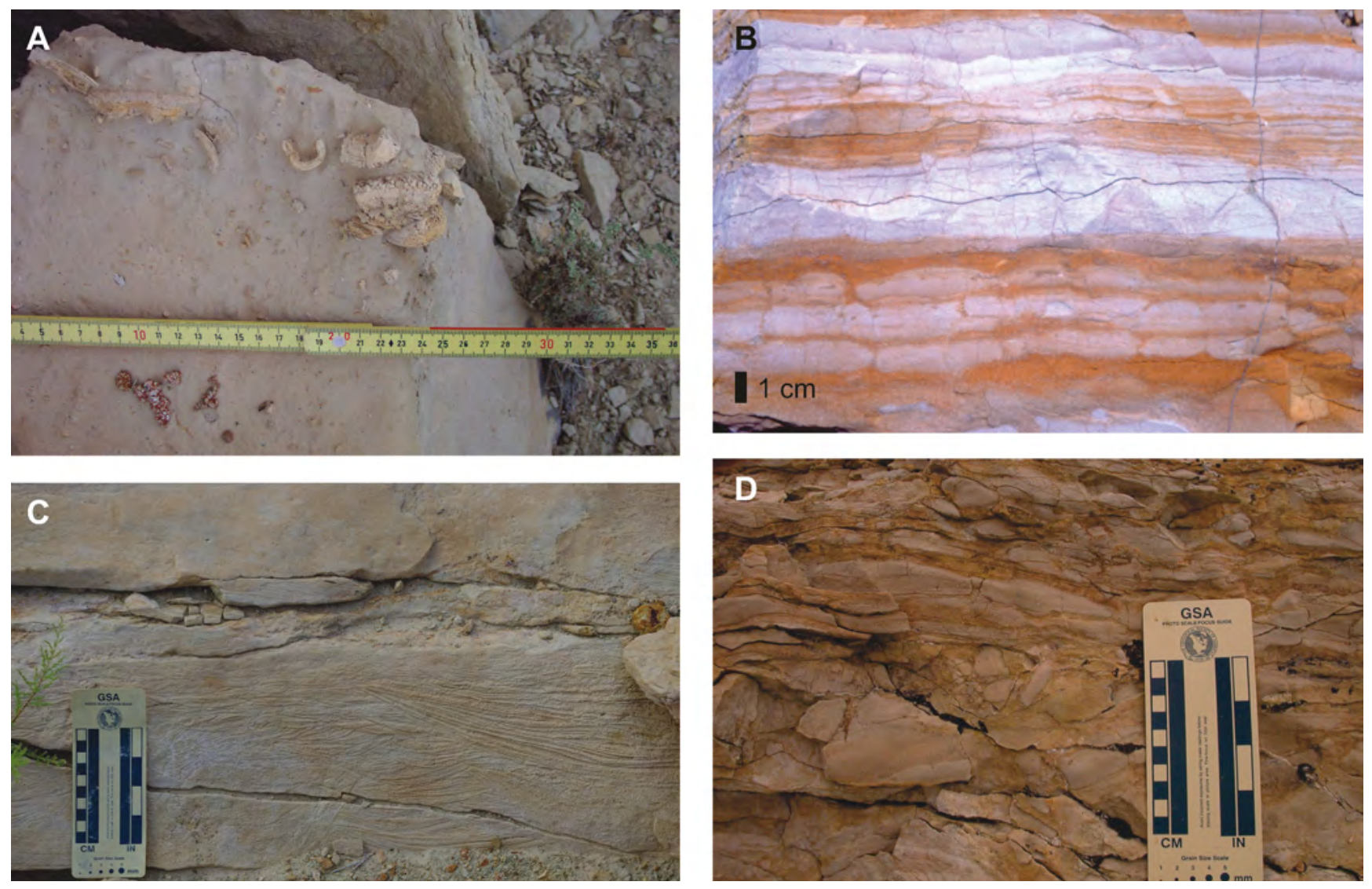

Figure 2.17. Photographs of lacustrine carbonate mudstones and quartzose sandstones in the Wilkins Peak Member at the southern basin periphery of the Greater Green River Basin. (A) Peloidal-quartzose sandstone with intraclasts composed of travertine. (B) Centimeter-bedded silty micrite with multiple generations of desiccation cracks. (C) Wave ripple cross-laminated quartzose sandstone. (D) Intraclastic conglomerate horizon composed of 1-4 centimeter clasts of peloid-rich marl overlain by mudcrack- and root-brecciated marl. (Photographs by M.E. Smith, Northern Arizona University, (A) taken in June 2004, (B) taken in June 2003, (C) taken in June 2006, (D) taken in June 2006.) 

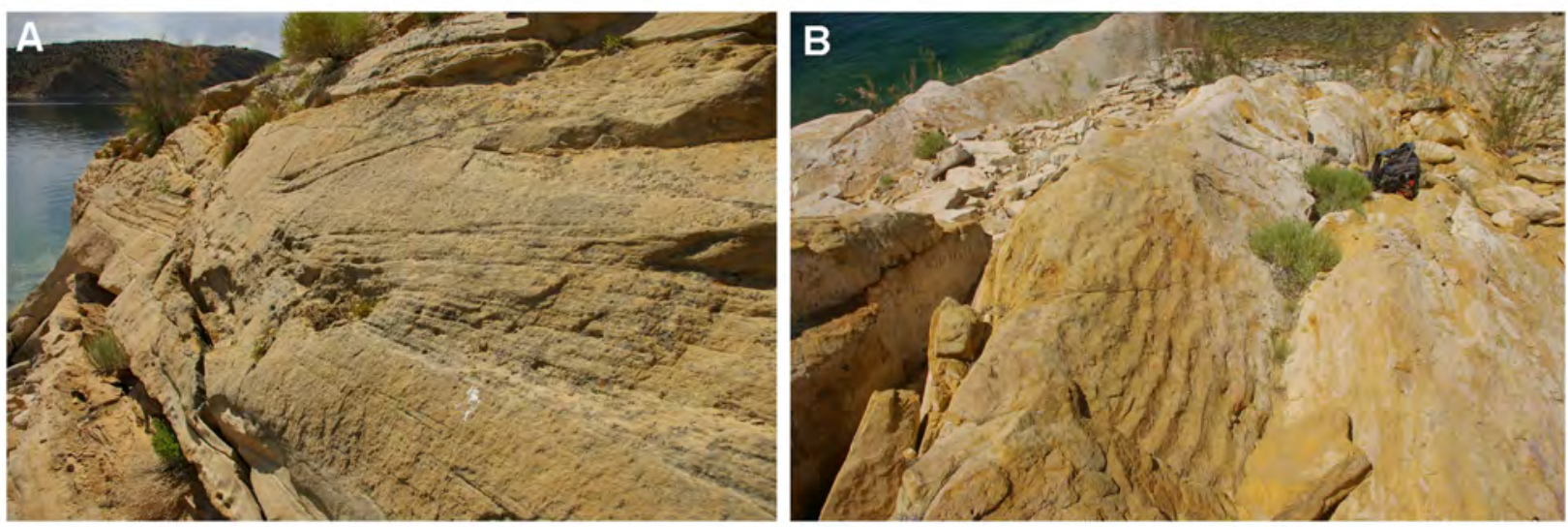

Figure 2.18. Photographs of sedimentary structures in sandstone-dominated Tipton Member of the Green River Formation in the southern periphery of the Greater Green River Basin. (A) Broad, low-angle cross-stratification (backpack for scale). (B) Sand beds topped with wave ripples, often preserve abundant trace fossils. Photographs by J.J. Scott, Mount Royal University, taken in June 2006.
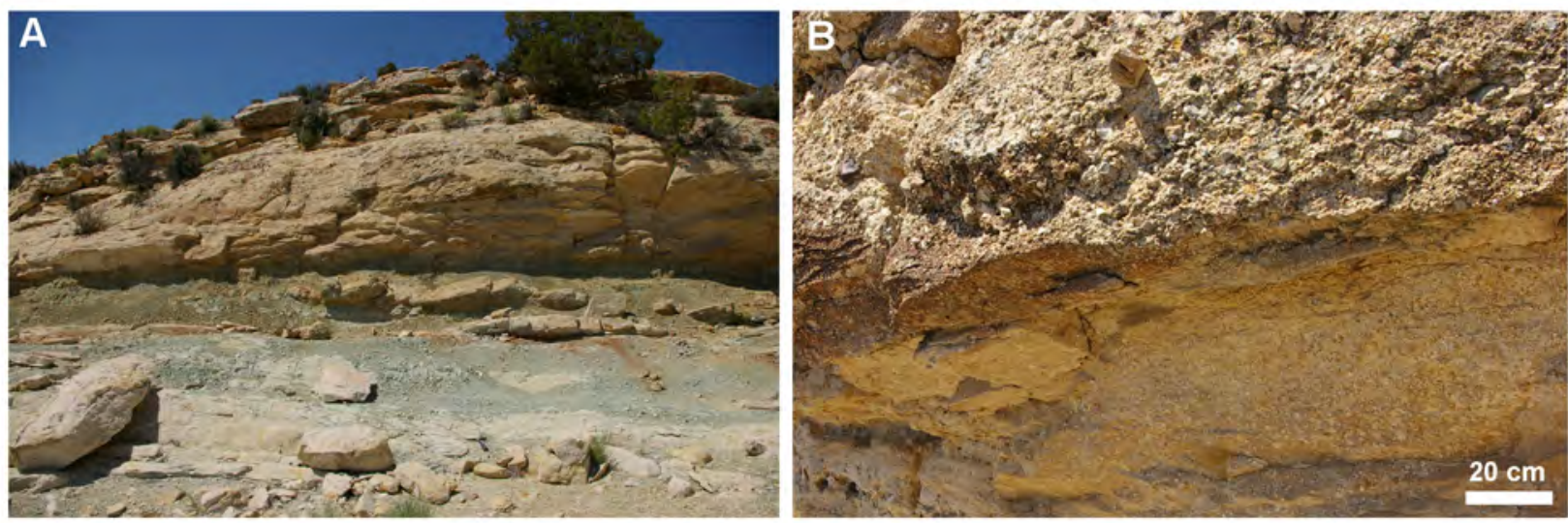

Figure 2.19. Photographs of alluvial facies (Cathedral Bluffs Member of the Wasatch Formation) at the basin periphery, typically consisting of resistant interbedded sandstone and conglomerate beds and recessive mudstone intervals. Green and red colors indicate pedogenic processes. (Photographs by J.J. Scott, Mount Royal University, taken in June 2007.)

\section{Trace Fossils and Sedimentary Environments}

The composition and distribution of trace fossil assemblages in the Pipeline section can be associated with the three main lake-type basins (Scott and others, 2012). The sand-dominated fluvial and shallow lacustrine beds in the lowermost part of the section represent the advection of clastics into the southern part of Lake Gosiute. Soft-ground trace fossils within the sandstones represent well-oxygenated and freshwater conditions (Scott and others, 2012), consistent with fluvial-lacustrine facies deposited in an overfilled lake basin. A change upsection to intercalated lacustrine shales and shallow lacustrine shoreface to foreshore and backshore sandstones represents the switch to balanced fill lake-type conditions. Lacustrine shales with gastropod-rich siltstones contain large U- and J-shaped burrows possibly produced by crayfish. The wave-rippled sandstone units preserve simple trails and U-shaped burrows possibly produced by mayflies. Most of the sandstone units also contain meniscate backfilled burrows produced by air-breathing insects, which represents subaerial exposure of the substrates before the next lake expansion event. The position of the shoreline at the basin margin, as well as the preservation of firmground burrows in sandstones, supports the interpretation that this portion of the section represents a balanced fill lake-type. Further upsection, alluvial fan facies and intercalated calcite-rich lacustrine beds represents the Wilkins Peak Member at the southern margin. Lacustrine lithofacies are dominated by organic-poor mudcracked laminated micrite and intraclastic to peloidal 
grainstones, some of which may be aeolian in origin. Trace fossils include those likely produced by crayfish in alluvial siltstones stratigraphically below alluvial fan sandstones and conglomerates, and firm ground burrows with scratch marks produced in thinly bedded shallow water sandstones. The composition of the trace fossil assemblages, and their association with terrestrial to shallow lacustrine sedimentary environments, is well aligned with the integrated model for traces in underfilled lake-type basins (Scott and others, 2012).

\section{Stop 7. The I-Bed Mound}

\section{Stop Summary}

This approximately 25-m-high silicified mound sits atop sandstone-mudstone unit I, which is dominated by Uinta Uplift-derived coarse-grained quartzose sandstone and pebble conglomerate. Megaquartz-filled fracture systems dissect the white-weathering microcrystalline calcitic, dolomitic, and silica-rich mound (fig. 2.20). This microcrystalline texture is unlike other microbial and tufa textures seen in the biohermal mounds found elsewhere in the GGRB, and is in sharp contrast to the underlying clastic beds. Some of the fractures are filled with sandstone of nearly the same composition as the underlying beds. The abundance of silica within the mound and the megaquartz-filled fractures suggests that the fluids from which the mound was precipitated were hydrothermal, and may have travelled through porous sandstones and conglomerates of the I-Bed alluvial fan. The timing of mound formation was syndepositional, but the timing of fracturing and silica-rich fluid flow is unresolved at this locality. Approximately $3 \mathrm{mi}$ to the west, tufa-travertine mounds dissected by silica-filled fractures are clearly in situ, and are associated with the deposition of the uppermost Wilkins Peak Member and overlying Laney Member.

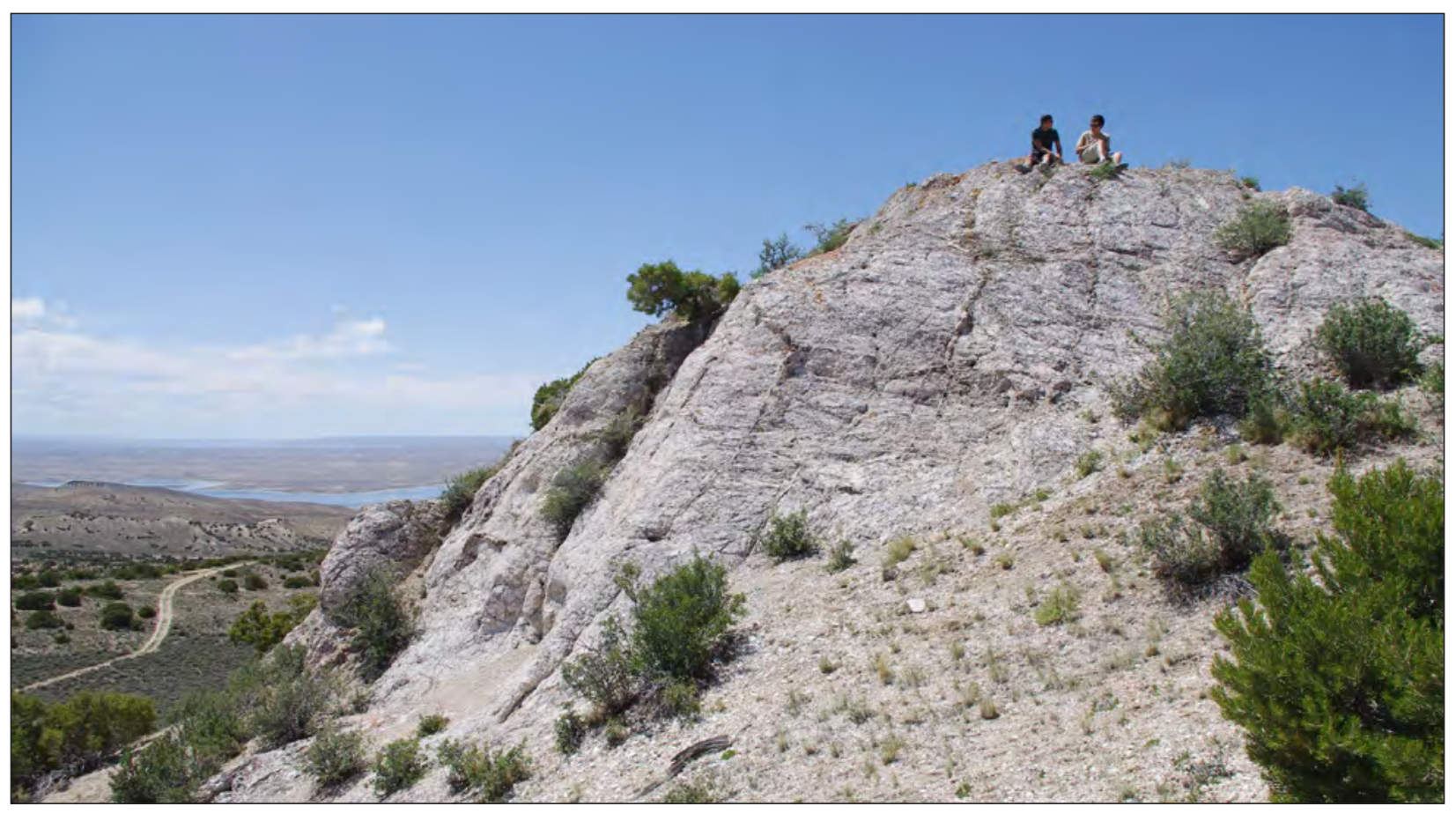

Figure 2.20. Photograph of approximately 25-meter-high silicified mound sitting atop sandstone-mudstone unit I, dominated by Uinta Uplift-derived coarse-grained quartzose sandstone and pebble conglomerate. (Photograph by J.J. Scott, Mount Royal University, taken in June 2013.) 


\section{Stop 8. The Cathedral Bluffs Member of the Wasatch Formation}

\section{Stop Summary}

Terrestrial alluvial fan facies of the Cathedral Bluff Member include paleosols, mudstones, conglomerates, and sandstones. Where exposed, these strata demonstrate along-strike variability in fluvial depositional environments ranging from incised tan sand-filled channels and green to red to purple-colored paleosol horizons (fig. 2.21).

\section{DAY 3. Syndeformational Green River Formation Adjacent to the Fold-Thrust Belt, Western GGRB}

The third day of the trip focuses on syndepositional deformation on the western margin of the Greater Green River Basin (GGRB) during deposition of the Wilkins Peak Member. These growth strata provide direct evidence for active deformation along the eastern edge of the Sevier fold and thrust belt.

As we travel out across the basin center from Rock Springs on our way to the western margin near Kemmerer, we pass through lacustrine facies of the entire GRF. The active trona mines we pass along the way mark the position of the evaporite depocenter during the upper Wilkins Peak Member. Our destination is an exposed section along the western margin that includes strata of the Wasatch Formation and overlying Tipton, Wilkins Peak, and Laney Members of the GRF.
Stop 9. Overview of White Mountain and the Basin Center, Rock Springs

\section{Stop Summary}

We begin the day with an overview of White Mountain from the western Rock Springs Uplift. Beds of the GRF dip westward at about $10^{\circ}$ off of the Rock Springs Uplift (fig. 2.22). The Tipton Member forms the lower bench near base of the "mountain," and the white-colored Wilkins Peak Member forms the main cliffs, with the thick middle arkosic sandstone unit (D-Bed) forming the brown horizon near the middle of the outcrop. Towards the upper part of White Mountain, gray-colored dolomitic shales of the upper Wilkins Peak Member form steep cliffs. The outcrop is capped with the buff-weathering LaClede Bed and Sand Butte Bed of the Laney Member.

\section{Syndepositional Deformation}

The Sand Butte Bed, which represents the filling of Lake Gosiute with sediment, will become visible as we travel towards the west, where spectacular views of the thick volcaniclastic sand bed provide evidence that this sediment was deposited quickly into soft sediment below. Although the base of this butte-forming sand unit is in sharp contrast with the underlying lakebeds and appears to represent an unconformity, the soft-sediment deformation of both the lakebeds and the volcaniclastic sand demonstrates that this is not the case. Instead, this is syndepositional deformation due to the rapid influx of sediment to the Lake Gosiute (fig. 2.23).

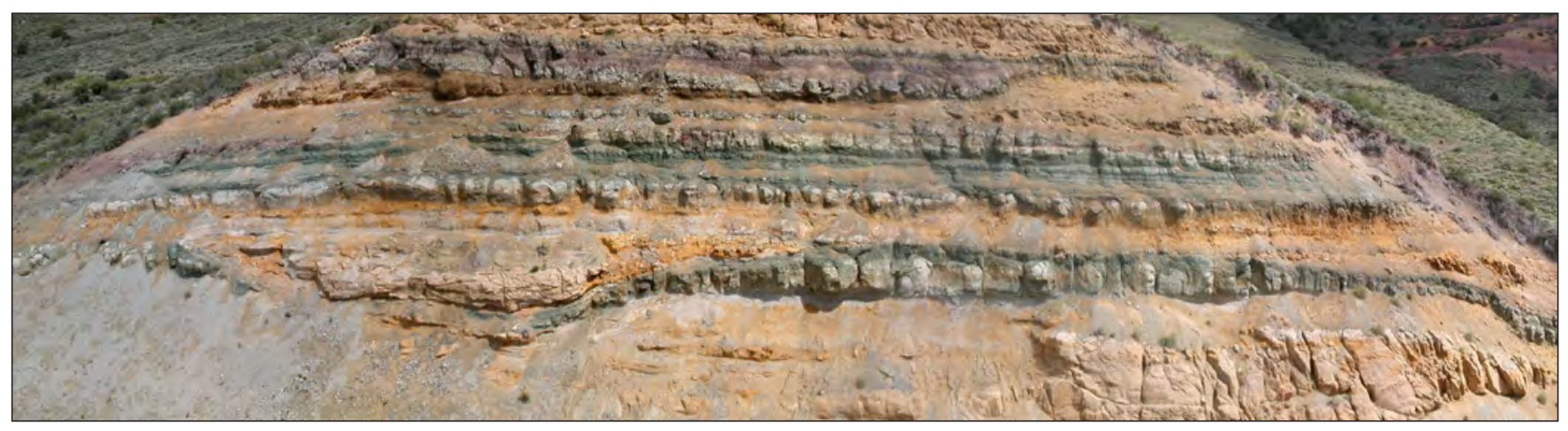

Figure 2.21. Photograph of outcrop of Wilkins Peak Member equivalent alluvial strata at Little Mountain. View is towards the north towards the Greater Green River Basin. (Photograph by M.E. Smith, Northern University, taken in June 2003.) 


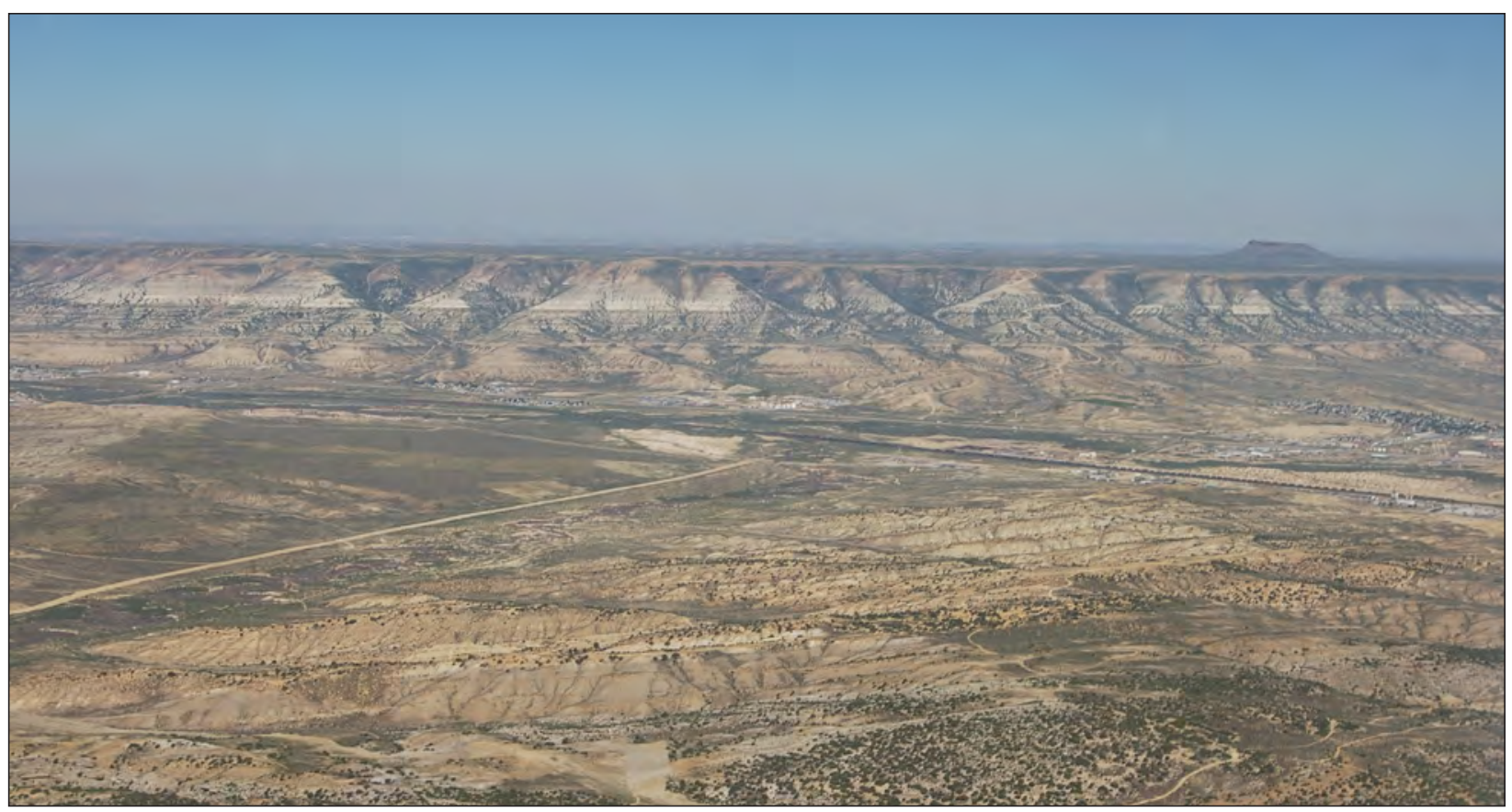

Figure 2.22. Photograph of White Mountain, forming the northwest skyline of Rock Springs, Wyoming. The west-dipping cuesta exposes the entire Green River Formation. Wasatch Formation alluvial strata form the foreground. (Photograph by J.J. Scott, Mount Royal University, taken in June 2008.)

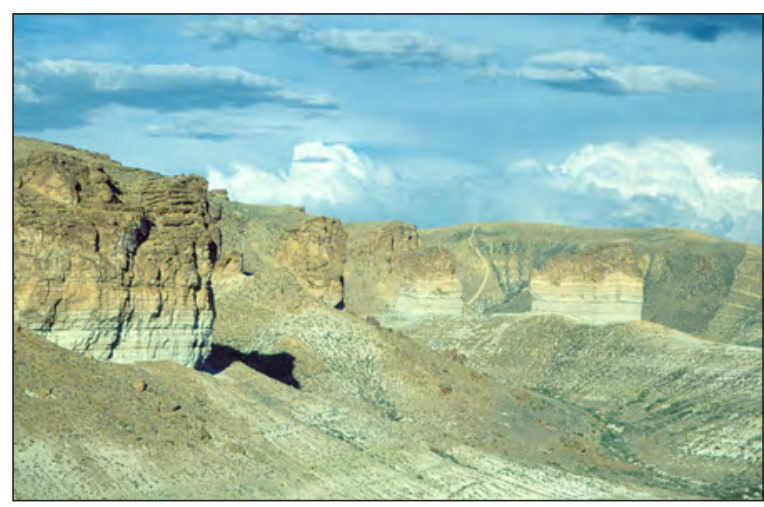

Figure 2.23. Photograph of load structures at the base of the deltaic Sand Butte Bed of the Laney Member. These structures locally displace underlying oil shales of the LaClede Bed of the Laney Member. (Photograph by M.E. Smith, Northern Arizona University, taken in July 2004.) 


\section{Stop 10. Uplift on the Easternmost Thrust in the Middle Eocene, Round Mountain}

\section{Stop Summary}

This short stop and overview highlights steeply dipping Jurassic and Triassic strata involved in the Hogsback thrust, which are overlain unconformably by relatively flat-lying lakebeds of the Green River Formation (fig. 2.24). This folded structure in the curved thrust salient of the Sevier fold and thrust belt is one of the youngest structures that directly affected deposition in the Green River Formation. As we travel towards the northeast to Slate Creek, observe the gentle warping of the overlying lakebeds above this structure and the broad folding between this structure and the section at Slate Creek (fig. 2.25).

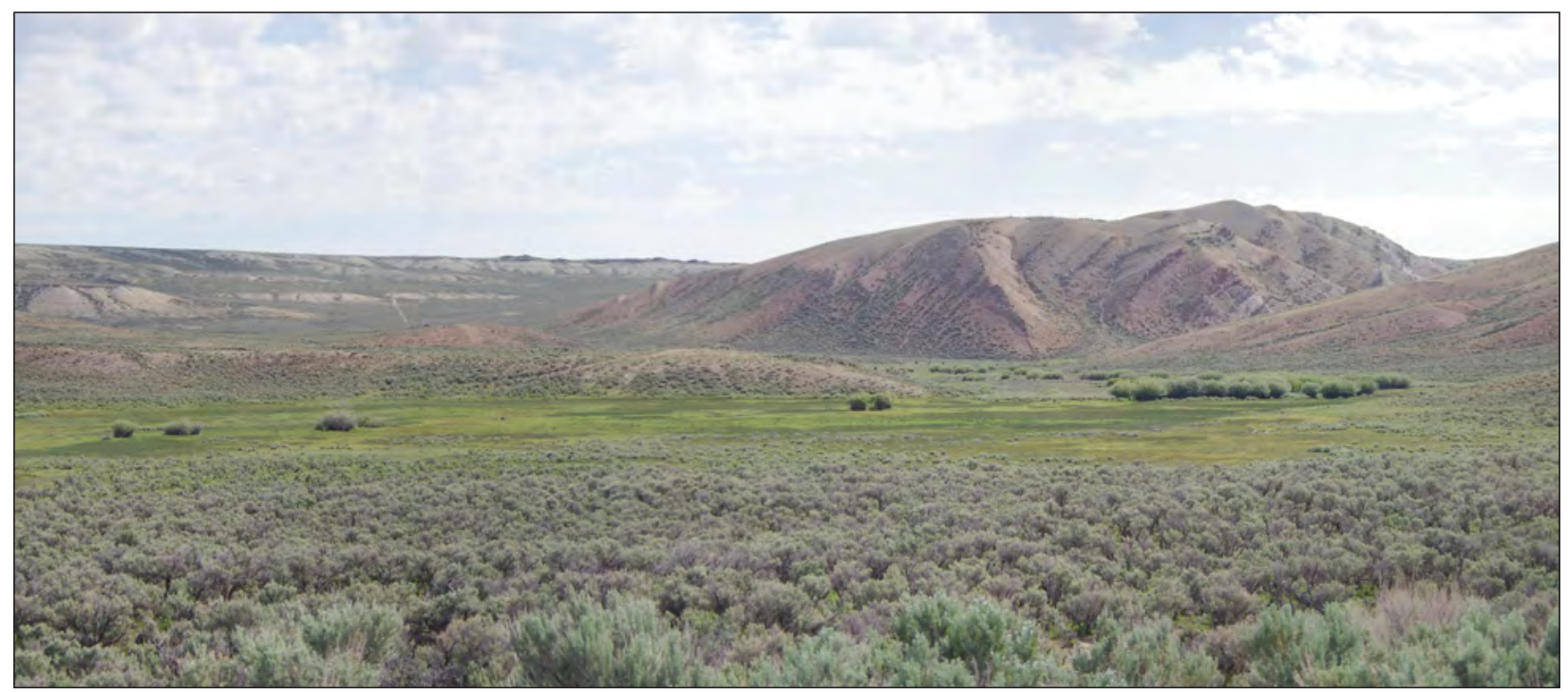

Figure 2.24. Photograph showing overview of steeply dipping Jurassic strata of the Hogsback Thrust system near Round Mountain, east of Kemmerer, Wyoming. (Photograph by J.J. Scott, Mount Royal University, taken in July 2013.)

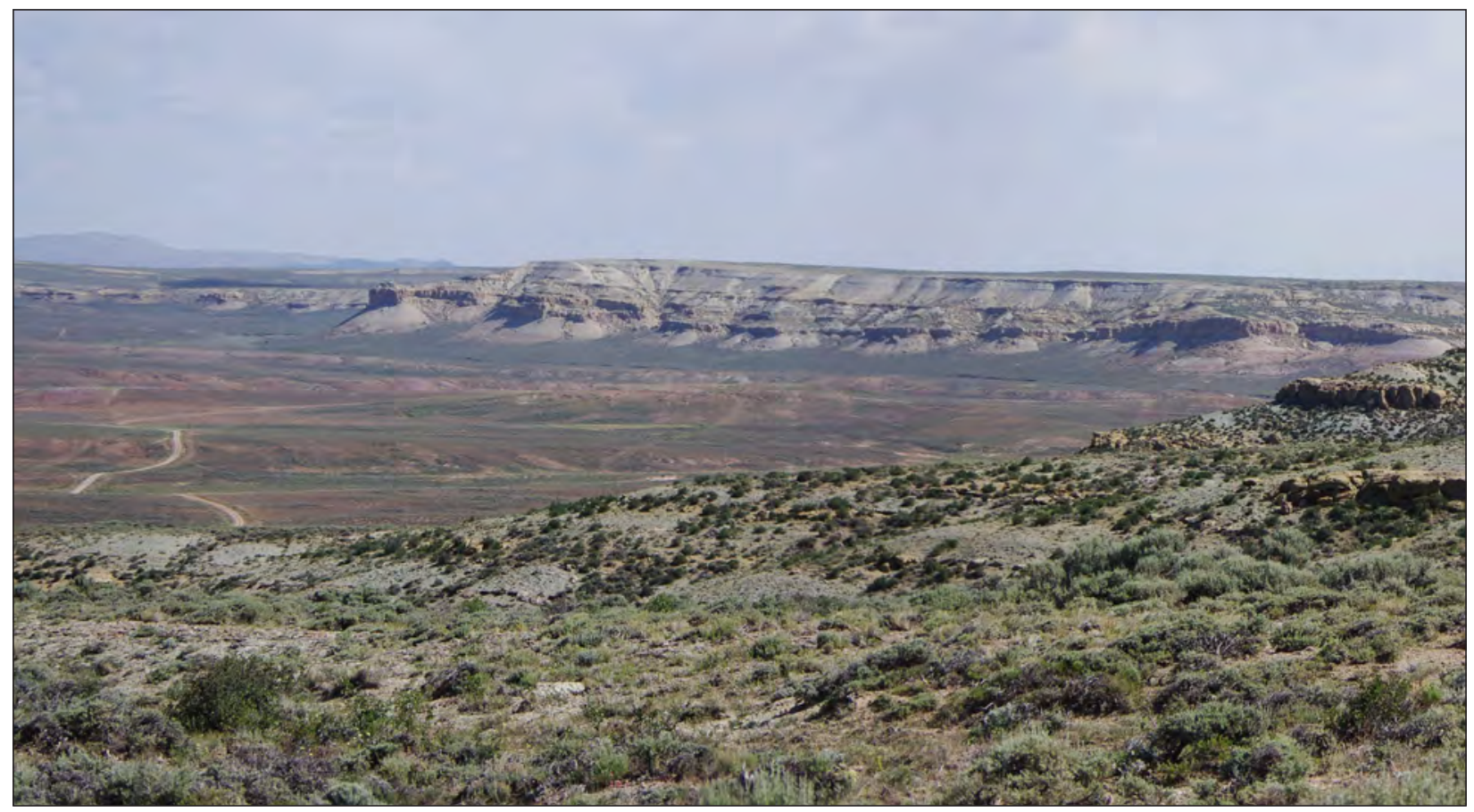

Figure 2.25. Photograph showing overview of Slate Creek area, with the Farson Sandstone forming sandstone cliffs on lower part of the outcrop in distance. (Photograph by J.J. Scott, Mount Royal University, taken in July 2013.) 

Stop 11. Syndepositional Deformation on the
Western Margin, Slate Creek

\section{Stop Summary}

The section at Slate Creek begins with the Wasatch Formation and includes all members of the Green River Formation. This area was tectonically active during deposition of the Green River Formation, which is most clearly evidenced by growth strata within Wilkins Peak lakebeds that progressively onlap a fold (Scott, 2010) (fig. 2.26).

\section{Stratigraphy, Sedimentary Environments, and Trace Fossils}

The stratigraphy and lithofacies on the western margin of the Bridger subbasin differ from those of the basin center (Day 1) and the southern basin margin (Day 2). Trace fossils are dominated by meniscate backfilled burrows produced by air-breathing organisms in eulittoral mudflat and alluvial environments, and compare well with those seen on Day 1 and Day 2.

\section{Stratigraphy}

Along with carbonate lakebeds, the western margin section also includes: (1) the Farson Sandstone, a deltaic unit of the Tipton Member found in the northern part of the GGRB; and (2) purplish lithic sandstones and bright green silty alluvium of the Cathedral Bluffs Member of the Wasatch Formation. The Wilkins Peak lacustrine beds here are relatively thin (about $25 \mathrm{~m}$ ), and are overlain by deltaic to fluvial lithic sandstones below the Laney Member buff-colored siltstones.

\section{Sedimentary Environments}

Alluvium of the red-colored Wasatch Formation is overlain by siltstones of the Schegg's Bed of the Tipton Member and the deltaic Farson Sandstone. Gentle folding of the lower stratigraphic units is clearly seen when viewing the light brown siltstones of the Tipton Member Schegg's Bed, which dip towards the west. Green siltstones and purplish brown and yellow sandstones of the alluvial Cathedral Bluffs Member appear to cross-cut the lower units, which dip towards the northeast. These facies contain meniscate backfilled burrows preserved within the sandstones that indicate subaerial exposure.

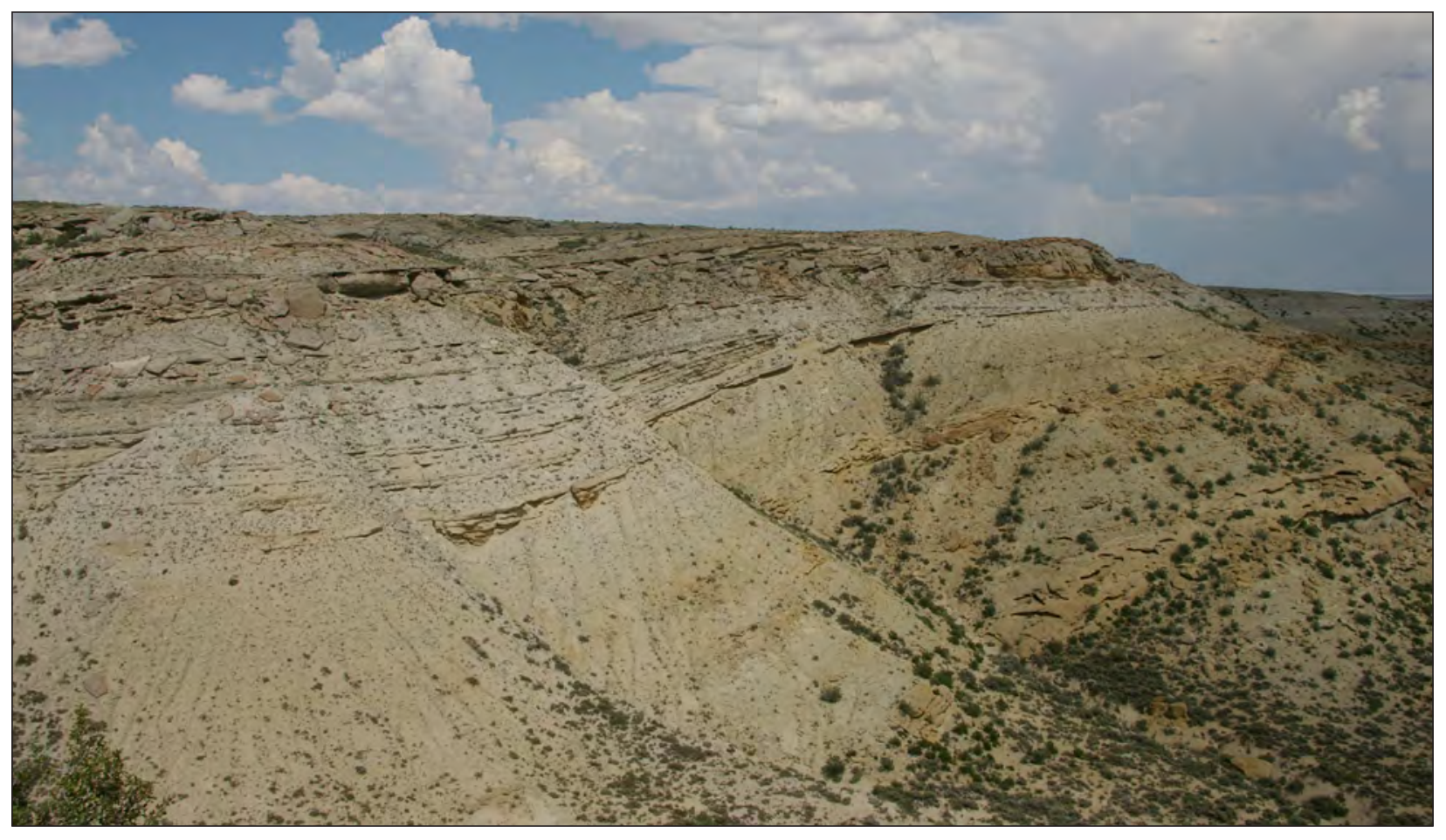

Figure 2.26. Photograph at Slate Creek showing onlap of lacustrine growth strata onto progressively uplifted fold in the western thrust belt. (Photograph by J.J. Scott, Mount Royal University, taken in June 2007.) 
At the base of the Wilkins Peak Member, a stromatolite clast-dominated (about 70 percent) conglomerate marks the initiation of lake flooding against the syndeformational anticline (fig. 2.26). Dark brown lacustrine shales with minor evaporites and thin stromatolites contrast sharply with the underlying alluvial facies, and progressively onlap a fold. Wave-rippled shallow lacustrine, eulittoral mudflat facies, and cross-bedded fluvial sandstones represent the uppermost Wilkins Peak at this locality. A purplish gray lithic sandstone with abundant meniscate backfilled burrows marks a return to subaerial conditions (fig. 2.26). This sandstone is overlain by buff-colored siltstones of the Laney Member that mark renewed lake inundation.

\section{Trace Fossils}

Meniscate backfilled burrows of three size classes are observed at this locality. The relationship with sedimentary facies and these size classes illustrates that the smaller burrows (about $4 \mathrm{~mm}$ diameter) are predominantly horizontal and were produced in relatively wet sediments, the medium-sized burrows (about $7 \mathrm{~mm}$ diameter) cross-cut the smaller burrows as the sediments desiccated, and the large-sized burrows (about 15-20 mm diameter), which are mainly vertically oriented, represent well-drained subaerial substrates away from the shoreline (fig. 2.27).
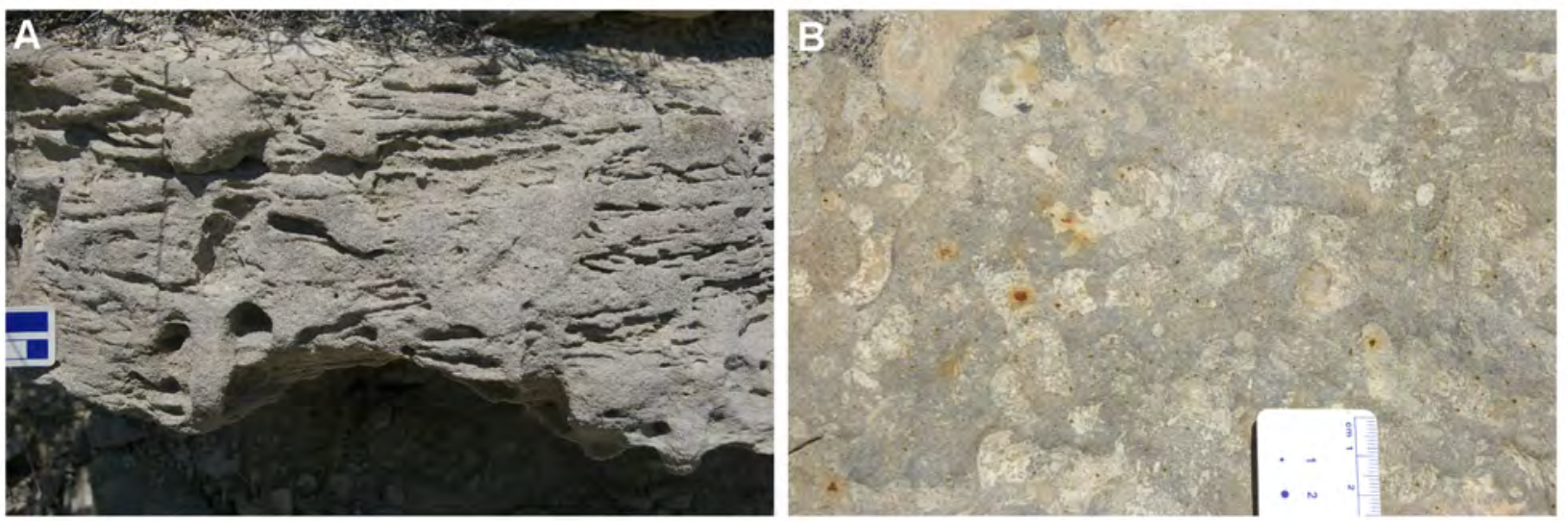

Fig. 2.27. Photographs of meniscate backfilled burrows on horizon marking cessation of tectonic activity on the western thrust belt at Slate Creek. Scale bars are in centimeters. (A) Cross section showing large vertically oriented burrows in lithic sandstone. (B) Plan view showing medium-sized and large meniscate backfilled burrows with heterolithic fill of lithic sandstone and carbonate mudstone. (Photograph by J.J. Scott, Mount Royal University, taken in June 2007.)

\section{Trip Summary}

Through this field trip, we investigate tectonics, climate, and paleogeomorphology as interacting controls on deposition of the Eocene Green River Formation in the Greater Green River Basin, with a focus on the Wilkins Peak Member in the Bridger subbasin. Considered at various scales, each of these controls contributed to the history of the lake system and the distribution and vertical packaging of the sedimentary deposits that accumulated, including vast quantities of oil shales and soda ash. The three days of the trip each focus on a different area of the Bridger subbasin, between which lithologies and sediment packaging styles vary. By better understanding the variable expression of local parameters in each area of the subbasin, we see that the lake system was an integrated whole that responded to similar tectonic, climatic, and paleogeomorphological controls

\section{Acknowledgments}

We are extremely grateful for the generosity and mentorship of Ph.D. supervisors and friends: Alan R. Carroll and Brad S. Singer (University of Wisconsin-Madison) and Robin W. Renaut and Luis A. Buatois (University of Saskatchewan). They have contributed directly to our understanding of the Green River Formation, the Wilkins Peak Member, and lakes in general by sharing their ideas, experience, and breadth of knowledge from other basins through Earth history. 


\section{References Cited}

Aswasereelert, W., Meyers, S.R., Carroll, A.R., Peters, S.E., Smith, M.E., and Feigl, K.L., 2013, Basin-scale cyclostratigraphy of the Green River Formation, Wyoming: Geological Society of America Bulletin, v. 125, p. 216-228.

Beck, R.A., Vondra, C.F., Filkins, J.E., and Olander, J.D., 1988, Syntectonic sedimentation and Laramide basement thrusting, Cordilleran foreland; Timing of deformation, in Schmidt, C.J., and Perry, W.J., Jr., eds., Interaction of the Rocky Mountain Foreland and the Cordilleran Thrust Belt: Geological Society of America Memoir 171, p. 465-487.

Bohacs, K.M., Carroll, A.R., Neal, J.E., and Mankiewicz, P.J., 2000, Lake-basin type, source potential, and hydrocarbon character-An integrate sequence-stratigraphicgeochemical framework, in Gierlowski-Kordesch, E.H., and Kelts, K.R., eds., Lake basins through space and time: American Association of Petroleum Geologists Studies in Geology, v. 46, p. 3-34.

Bradley, W.H., 1929, The varves and climate of the Green River epoch: U.S. Geological Survey Professional Paper 158-E, $110 \mathrm{p}$.

Bradley, W.H., 1964, The geology of the Green River Formation and associated Eocene rocks in southwestern Wyoming and adjacent parts of Colorado and Utah: U.S. Geological Survey Professional Paper 496-A, 86 p.

Burnside, M.J., and Culbertson, W.C., 1979, Trona deposits in the Green River Formation, Sweetwater, Uinta, and Lincoln Counties, Wyoming: U.S. Geological Survey Open-File Report 79-737, 10 p.

Carroll, A.R., and Bohacs, K.M., 1999, Stratigraphic classification of ancient lakes - Balancing tectonic and climatic controls: Geology, v. 27, p. 99-102.

Clyde, W.C., Sheldon, N.D., Koch, P.L., Gunnell, G.F., and Bartels, W.S., 2001, Linking the Wasatchian/Bridgerian boundary to the Cenozoic global climate optimum-New magnetostratigraphic and isotopic results from South Pass, Wyoming: Palaeogeography, Palaeoclimatology, Palaeoecology, v. 167, p. 175-199.

Clyde, W.C., Zonneveld, J.-P., Stamatakos, J., Gunnell, G.F., and Bartels, W.S., 1997, Magnetostratigraphy across the Wasatchian/Bridgerian NALMA boundary (early to middle Eocene) in the western Green River Basin, Wyoming: The Journal of Geology, v. 105, p. 657-669.

Culbertson, W.C., 1961, Stratigraphy of the Wilkins Peak Member of the Green River Formation, Firehole Basin quadrangle, Wyoming: U.S. Geological Survey Professional Paper 424-D, p. 170-173.
Dickinson, W.R., Klute, M.A., Hayes, M.J., Janecke, S.U., Lundin, E.R., McKittrick, M.A., and Olivares, M.D., 1988, Paleogeographic and paleotectonic setting of Laramide sedimentary basins in the central Rocky Mountain region: Geological Society of America Bulletin, v. 100, p. 1,023-1,039.

Doebbert, A.C., Carroll, A.R., Mulch, A., Chetel, L.M., and Chamberlain, C.P., 2010, Geomorphic controls on lacustrine isotopic compositions_-Evidence from the Laney Member, Green River Formation, Wyoming: Geological Society of America Bulletin, v. 122, p. 236-252.

Eugster, H.P., and Hardie, L.A., 1975, Sedimentation in an ancient playa-lake complex: The Wilkins Peak Member of the Green River Formation of Wyoming: Geological Society of America Bulletin, v. 86, p. 319-334.

Fischer, A.G., and Roberts, L.T., 1991, Cyclicity in the Green River Formation (lacustrine Eocene) of Wyoming: Journal of Sedimentary Petrology, v. 61, p. 1,146-1,154.

Grande, L., 1984, Paleontology of the Green River Formation, with a review of the fish fauna $(2 \mathrm{~d}$ ed.): The Geological Survey of Wyoming Bulletin 63, 333 p.

Hyland, E.G., and Sheldon, N.D., 2013, Coupled $\mathrm{CO}_{2}$-climate response during the Early Eocene Climatic Optimum: Palaeogeography, Palaeoclimatology, Palaeoecology, v. 369, p. 125-135.

Kuiper, K.F., Deino, A., Hilgen, F.J., Krijgsman, W., Renne, P.R., and Wijbrans, J.R., 2008, Synchonizing rock clocks of Earth history: Science, v. 320, p. 500-504.

Laskar, J., Robutel, P., Joutel, F., Gastineau, M., Correia, A.C.M., and Levrard, B., 2004, A long term numerical solution for the insolation quantities of the Earth: Astronomy and Astrophysics, v. 428, p. 261-285.

Min, K., Mundil, R., Renne, P.R., and Ludwig, K.R., 2000, A test for systematic errors in ${ }^{40} \mathrm{Ar} /{ }^{39} \mathrm{Ar}$ geochronology through comparison with $\mathrm{U}-\mathrm{Pb}$ analysis of a $1.1 \mathrm{Ga}$ rhyolite: Geochimica et Cosmochimica Acta, v. 64, p. 73-98.

Mott, L.V., and Drever, J.I., 1983, Origin of uraniferous phosphatic beds in Wilkins Peak Member of the Green River Formation: American Association of Petroleum Geologists Bulletin, v. 67, p. 70-82.

Pietras, J.T., and Carroll, A.R., 2006, High-resolution stratigraphy of an underfilled lake basin-Wilkins Peak Member, Eocene Green River Formation, Wyoming, USA: Journal of Sedimentary Research, v. 76, p. 1,197-1,214.

Roehler, H.W., 1993, Eocene climates, depositional environments, and geography, Greater Green River Basin, Wyoming, Utah, and Colorado: U.S. Geological Survey Professional Paper 1506-F, 74 p. 
Scott, J.J., 2010, Saline lake ichnology-Composition and distribution of Cenozoic traces in the saline, alkaline lakes of the Kenya Rift Valley and Eocene Green River Formation, U.S.A.: Saskatoon, University of Saskatchewan, Ph.D. thesis, 526 p.

Scott, J.J., Buatois, L.A., and Mangano, M.G., 2012, Lacustrine environments, in Knaust, D., and Bromley, R., eds., Trace Fossils as indicators of sedimentary environments, Volume 64-Developments in Sedimentology: Elsevier, p. 379-417.

Scott, J.J., and Smith, M.E., 2015, Trace fossils of the Eocene Green River lake basins, Wyoming, Utah, and Colorado, in Smith, M., and Carroll, A., eds., Stratigraphy and Paleolimnology of the Green River Formation, Western USA, Syntheses in Limnology: Springer, in press, DOI 10.1007/978-94-017-9906-5_12.

Sears, J.D., and Bradley, W.H., 1924, Relations of the Wasatch and Green River Formations in northwestern Colorado and southern Wyoming: U.S. Geological Survey Professional Paper 132-F, p. 93-107.

Smith, M.E., Carroll, A.R., Scott, J.J., and Singer, B.S., 2014a, Early Eocene carbon isotope excursions and landscape destabilization at eccentricity minima-Green River Formation of Wyoming: Earth and Planetary Science Letters, v. 403, p. 393-406.

Smith, M.E., Carroll, A.R., and Singer, B.S., 2008, Synoptic reconstruction of a major ancient lake system-Eocene Green River Formation, Western United States: Geological Society of America Bulletin, v. 120, p. 54-84.

Smith, M.E., Chamberlain, K.R., Singer, B.S., and Carroll, A.R., 2010, Eocene clocks agree-Coeval ${ }^{40} \mathrm{Ar} /{ }^{39} \mathrm{Ar}, \mathrm{U}-\mathrm{Pb}$, and astronomical ages from the Green River Formation: Geology, v. 38, p. 527-530.

Smith, M.E., Carroll, A.R., Scott, J.J., and Singer, B.S., 2014a, Early Eocene carbon isotope excursions and landscape destabilization at eccentricity minima-Green River Formation of Wyoming: Earth and Planetary Science Letters, v. 403, p. 393-406.

Smith, M.E., Jicha, B.R., Carroll, A.R., Cassel, E J., and Scott, J.J., 2014b, Paleogeographic record of Eocene Farallon slab rollback beneath western North America: Geology, v. 42, p. 1,039-1,042.
Smoot, J.P., 1983, Depositional subenvironments in an arid closed basin; the Wilkins Peak Member of the Green River Formation (Eocene), Wyoming, U.S.A.: Sedimentology, v. 30, p. 801-827.

Surdam, R.C., and Stanley, K.O., 1980, Effects of changes in drainage-basin boundaries on sedimentation in Eocene Lakes Gosiute and Uinta of Wyoming, Utah, and Colorado: Geology, v. 8, p. 135-139.

Tsukui, K., and Clyde, W.C., 2012, Fine-tuning the calibration of the early to middle Eocene geomagnetic polarity time scale-Paleomagnetism of radioisotopically dated tuffs from Laramide foreland basins: Geological Society of America Bulletin, v. 124, p. 870-885.

U.S. Geological Survey, 2015, 2013 Minerals Yearbook: accessed May 21, 2015, at http://minerals.usgs.gov/ minerals/pubs/commodity/soda_ash/myb1-2013-sodaa.pdf.

Utah Division of Oil, Gas, and Mining, 2015, Utah oil production - by field (past 5 years): Web site, accessed May 21, 2015, at http://oilgas.ogm.utah.gov/Statistics/PROD_ Oil_field.cfm.

Wiig, S.V., Grundy, W.D., and Dyni, J.R., 1995, Trona resources in the Green River Basin, southwest Wyoming: U.S. Geological Survey Open-File Report 95-476, 91 p.

Woodburne, M.O., Gunnell, G.F., and Stucky, R.K., 2009, Climate directly influences Eocene mammal faunal dynamics in North America: Proceedings of the National Academy of Sciences of the United States of America, v. 106, p. 13,399-13,403.

Zachos, J.C., Dickens, G.R., and Zeebe, R.E., 2008, An early Cenozoic perspective on greenhouse warming and carboncycle dynamics: Nature, v. 451, p. 279-283.

Zachos, J.C., McCarren, H., Murphy, B., Röhl, U., and Westerhold, T., 2010, Tempo and scale of late Paleocene and early Eocene carbon isotope cycles-Implications for the origin of hyperthermals: Earth and Planetary Science Letters, v. 299, p. 242-249.

Zonneveld, J.-P., Gunnell, G.F., and Bartels, W.S., 2000, Early Eocene fossil vertebrates from the southwestern Green River basin, Lincoln and Uinta counties, Wyoming: Journal of Vertebrate Paleontology, v. 20, p. 369-386 . 
Day 1. Basin Interior Green River Formation in Firehole and Sage Creek Canyons (June 12, 2015)

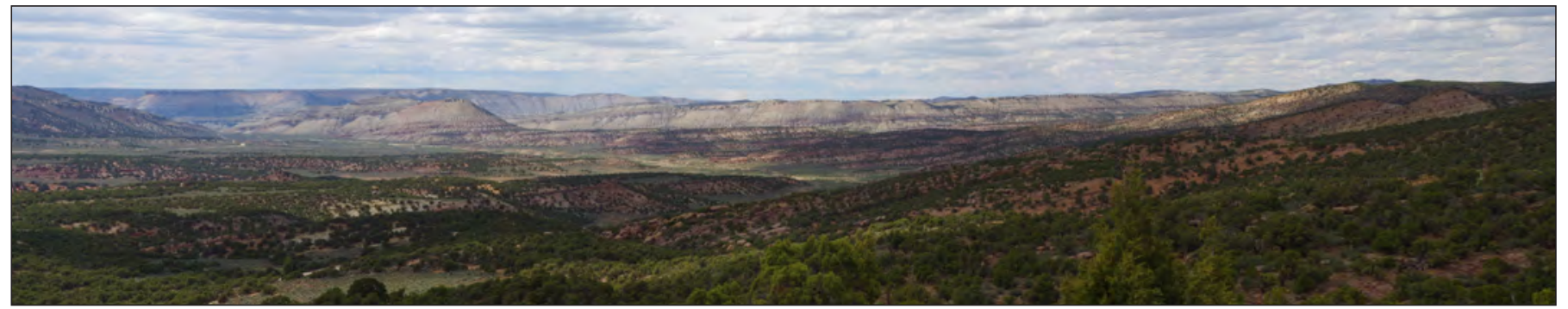

Head west on Interstate 80 from Rock Springs, WY. Take exit 99 onto US 191 south. Mileage begins at the highway 191 overpass over I-80.

\begin{tabular}{|c|c|c|}
\hline $\begin{array}{l}\text { Cumulative } \\
\text { Mileage }\end{array}$ & $\begin{array}{l}\text { Incremental } \\
\text { Mileage }\end{array}$ & \\
\hline 0.0 & 0.0 & $\begin{array}{l}\text { US } 191 \text { crosses Wasatch Formation strata that have been upturned on the western flank of the } \\
\text { Rock Springs Uplift. Green River Formation strata overlie the fluvially-deposited Wasatch } \\
\text { Formation and dip into the Bridger subbasin of the Greater Green River Basin. }\end{array}$ \\
\hline 13.6 & 13.6 & $\begin{array}{l}\text { Turn right onto the Flaming Gorge Road (Sweetwater Co. 33). We will drive up-section } \\
\text { through the Wasatch Formation and overlying Green River Formation. }\end{array}$ \\
\hline 14.5 & 0.9 & $\begin{array}{l}\text { Stop 1. Middle Firehole Canyon overview. From this vantage point, the entire Green River } \\
\text { Formation can be observed dipping west into the Bridger subbasin. }\end{array}$ \\
\hline 19.7 & 5.2 & $\begin{array}{l}\text { Travel west on the Flaming Gorge Road to where sandstone-mudstone unit A of the Wilkins } \\
\text { Peak Member crops out. } \\
\text { Stop 2. Unit A overlies a lacustrine interval consisting of kerogenous carbonate mudstone } \\
\text { that contains the distinctive "2 } 2^{\text {nd }} \text { tuff” of Culbertson (1961). }\end{array}$ \\
\hline 20.9 & 1.2 & $\begin{array}{l}\text { Travel west of the Flaming Gorge Road to where sandstone-mudstone unit D crops out. } \\
\text { Stop } 3 \text {. This exposure provides one of the best places to observe the internal stratigraphy and } \\
\text { sedimentary structures within the thickest of the distinctive brown alluvial marker horizons, } \\
\text { including both channelized alluvial lithofacies and lacustrine "inter-alluvial bed" lithofacies, } \\
\text { which contain elevated U and Th concentrations and some of the only stromatolites that occur } \\
\text { within the Wilkins Peak Member in the basin interior. }\end{array}$ \\
\hline 23.6 & 2.7 & $\begin{array}{l}\text { Lunch at the Firehole Canyon Picnic Area, located at approximately at the middle of the } \\
\text { evaporative Wilkins Peak Member of the Green River Formation. } \\
\text { Stop 4. Overview of Wilkins Peak - Laney Member transition }\end{array}$ \\
\hline 32.5 & 8.9 & $\begin{array}{l}\text { Follow the Flaming Gorge Road west and south from Firehole Canyon to its intersection with } \\
\text { the Sage Creek Road (Sweetwater Co. 36) within Sage Creek Canyon, turn left. }\end{array}$ \\
\hline 34.5 & 2.0 & $\begin{array}{l}\text { Follow the Sage Creek Road east to where sandstone-mudstone unit A crops out. } \\
\text { Stop 5. Unit A overlies the } 2^{\text {nd }} \text { tuff, and contains spectacular fluvial point bar deposits. }\end{array}$ \\
\hline 43.3 & 8.8 & Continue on the Sage Creek Road until it intersects with US 191, turn left. \\
\hline 89.1 & 45.8 & Return to Rock Springs on US 191. \\
\hline
\end{tabular}


Day 2. Basin Peripheral Green River Formation of the Southern Bridger subbasin (June 13, 2015)

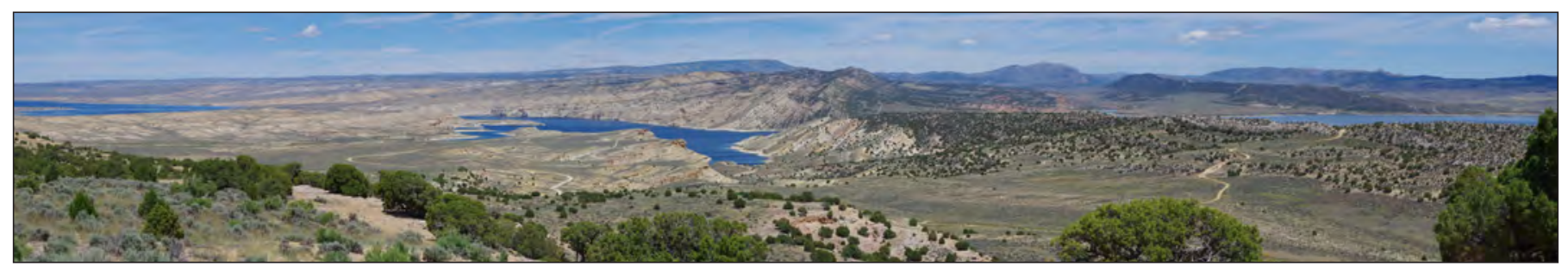

We will explore a little-explored section of the Green River Formation along the southern margin of the Bridger subbasin. These strata are distinctive from their basin interior counterparts, and contain evidence for inputs of quartzose alluvium and Ca-rich waters from the Uinta Uplift. Mileage begins at the highway 191 overpass over I-80 (see Day 1.)

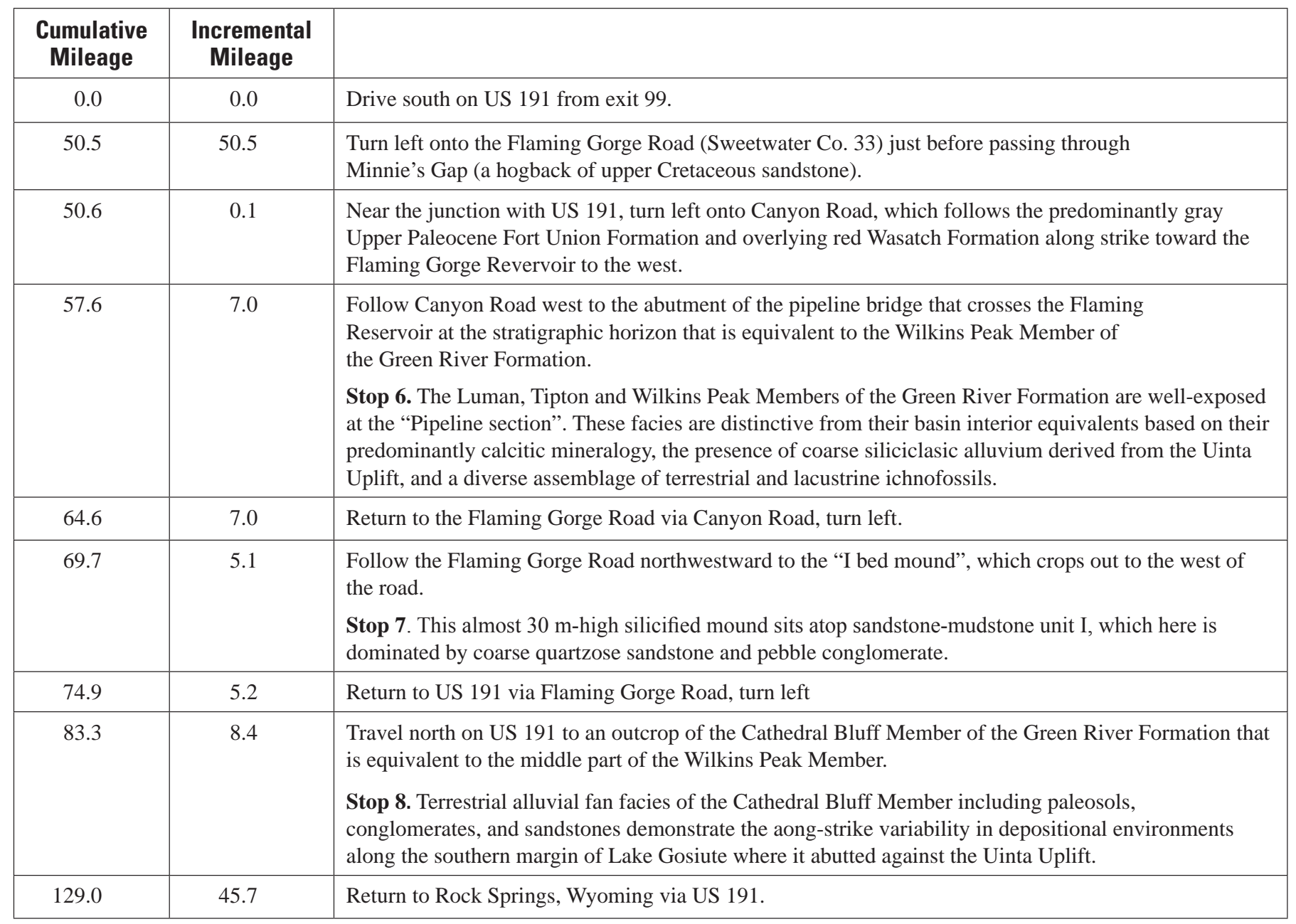


Day 3. Syndeformational Green River Formation at Slate Creek (June 14, 2015)

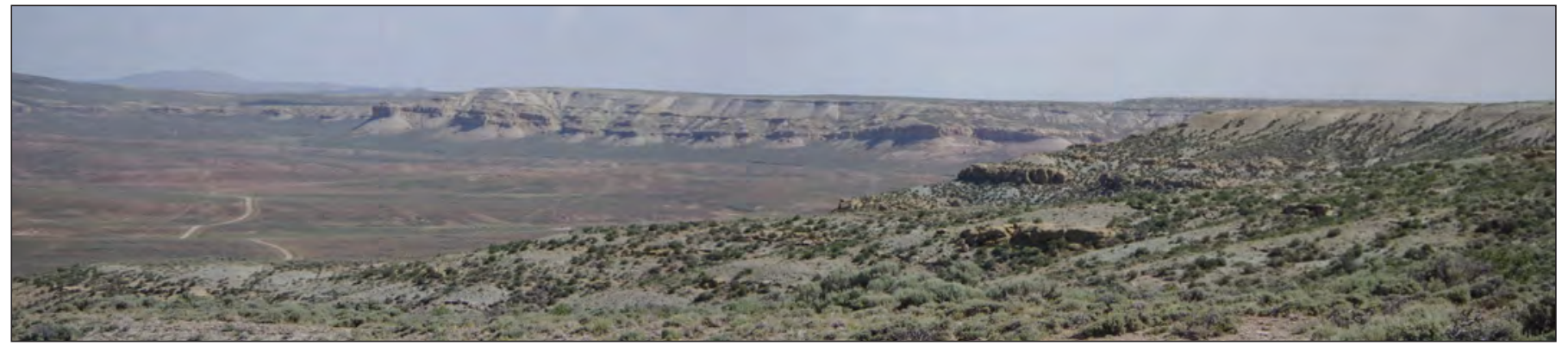

We will utilize our remaining time to explore a unique exposure of synorogenic Wilkins Peak Member strata adjacent to the Idaho-Wyoming-Utah fold and thrust belt that defines the western edge of the Greater Green River Basin.

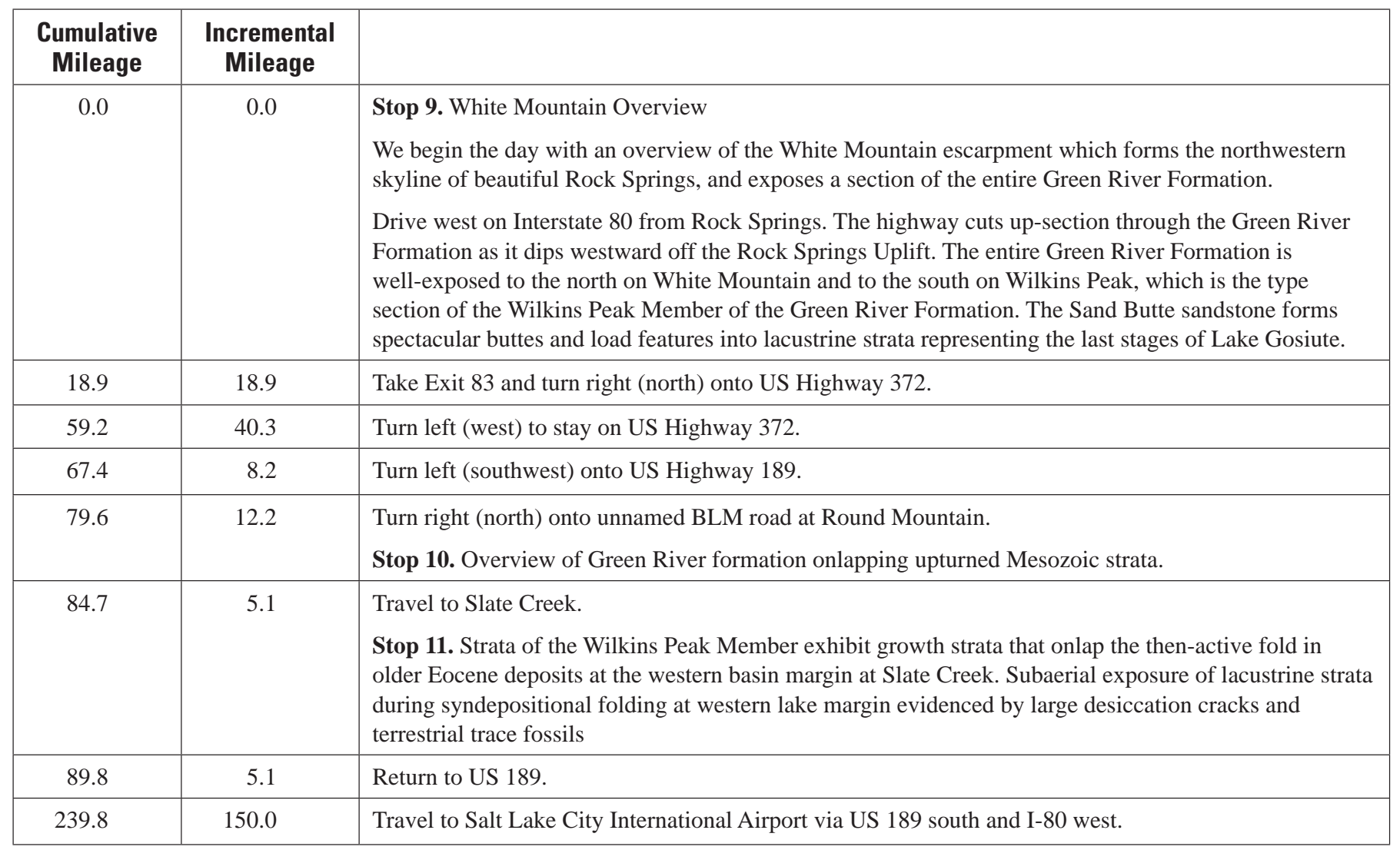




\title{
Trip 3.-Modern, Holocene, and Pleistocene Lake Locales in the Western Great Basin, Nevada and California, June 21-25, 2015
}

\author{
By Susan H. Zimmerman' ${ }^{1}$ Kenneth D. Adams ${ }^{2}$, and Michael R. Rosen ${ }^{3}$
}

\section{Introduction}

Great Basin lakes have been studied for more than 150 years starting with the U.S. Government-sponsored King Surveys of the 40th parallel (King, 1877) and continuing through detailed studies by Russell (1885), Gilbert (1890), Morrison (1964), and others. These studies and others concerning the formation of Pleistocene lakes (e.g., Smith and Street-Perrott, 1983; Benson and Thompson, 1987; Reheis and others, 2014) and the hydrology and geochemistry of desert basins (Gilbert, 1890; Jones, 1966; Mifflin, 1968) have provided the foundation for the current knowledge of the paleoclimate, sedimentology, and hydrology of the Great Basin and arid zones in general.
This field trip will take participants on a 5-day tour through the diversity of western Great Basin lakes stopping at modern lakes as well as at outcrops and landforms of Holocene and Pleistocene lakes that also existed in these basins. In addition, a few cultural stops along the way will allow participants to sample some Native American and western history.

Figure 3.1 provides the road map and stops for lakes/outcrops that will be included in this trip. The numbering of stops on the map is that used in the text. The first number refers to the day of the field trip that the stop occurs on and the second number refers to the sequence of stops for that particular day. The coordinates for each stop are in Universal Transverse Mercator Z11 North American Datum of 1983.

${ }^{1}$ Lawrence Livermore National Laboratory, California, LLNL-MI-671551.

${ }^{2}$ Desert Research Institute.

${ }^{3}$ U.S. Geological Survey. 


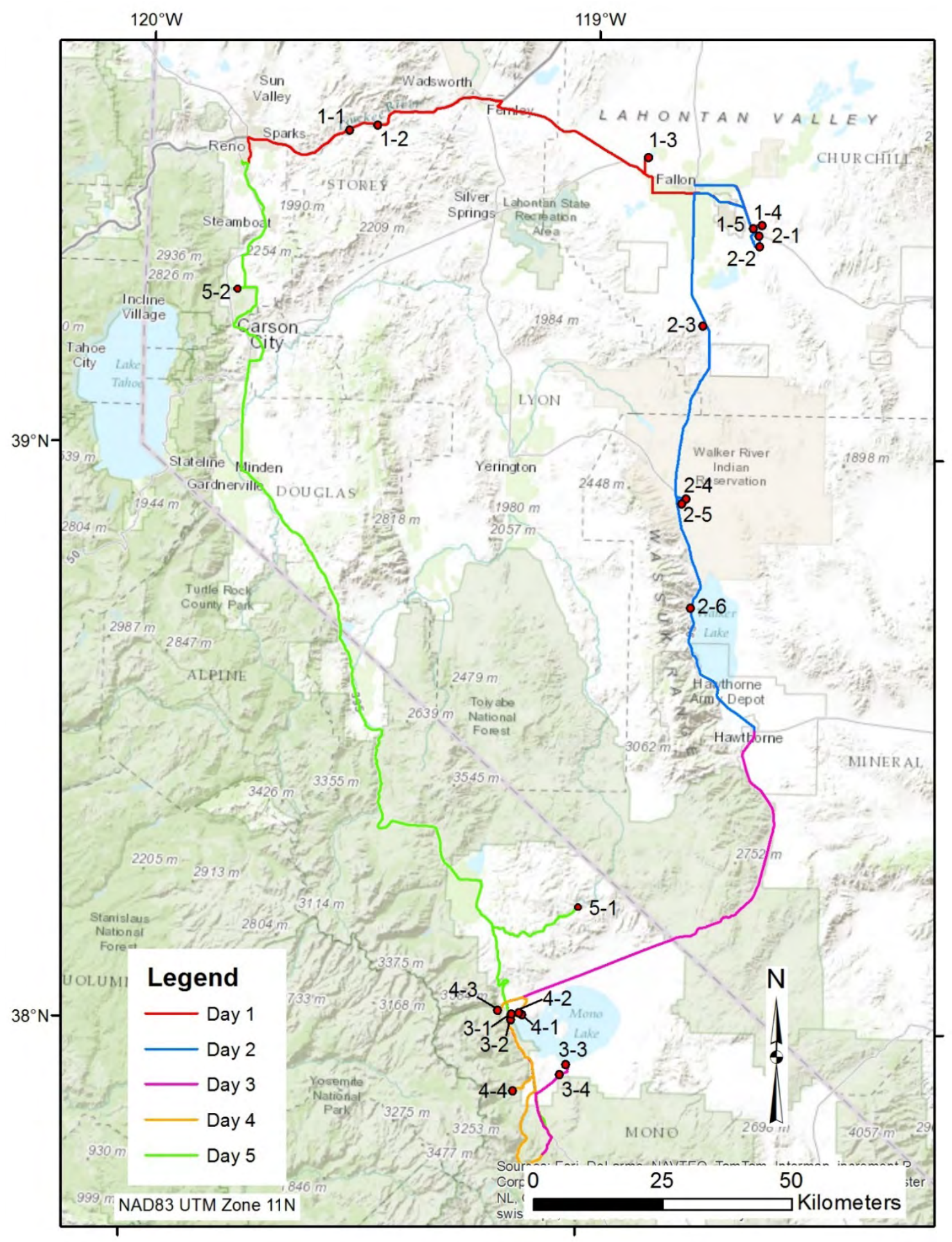

Figure 3.1. Map showing stops on the fieldtrip color-coded by day. The start and finish of the trip is in Reno, Nevada. Visiting Stop 5-2 at Washoe Lake will depend on time. 


\section{DAY 1. Reno to Fallon}

From Reno, travel east on I-80 into the canyon of the lower Truckee River where we will stop at two locations that exhibit possible evidence of large glacial outburst floods from Lake Tahoe into Lake Lahontan. Take Exit 28 (Patrick) and then turn right at the end of the off ramp. Proceed about $200 \mathrm{~m}$ toward the river to a gate on your right. Pass through the gate and drive about $500 \mathrm{~m}$ to the west-southwest to the south facing wall of this gravel pit.

\section{Stop 1-1. McCarren Ranch Gravel Pit (280119 E 4381620 N)}

On the north wall of this gravel pit, there are two boulder/ cobble fluvial deposits separated by a well-developed paleosol, which are in turn capped by much finer grained fluvial deltaic deposits of Lake Lahontan (fig. 3.2). The lower, coarser deposits contain boulders greater than or equal to $1 \mathrm{~m}$ in diameter that may represent glacial outburst flood deposits from Lake Tahoe (e.g., Birkeland, 1968). The amount of time represented by the paleosol is much longer than the amount of time elapsed since the last highstand of Lake Lahontan around 15 cal ka, based on relative soil development (e.g., Adams and Wesnousky, 1999). Therefore, the boulder deposits may be correlative with the Tahoe glaciation and the Eetza pluvial cycle, both of which have been correlated with marine isotope stage (MIS) 6 (Morrison, 1991; Gillespie and Clark, 2011).

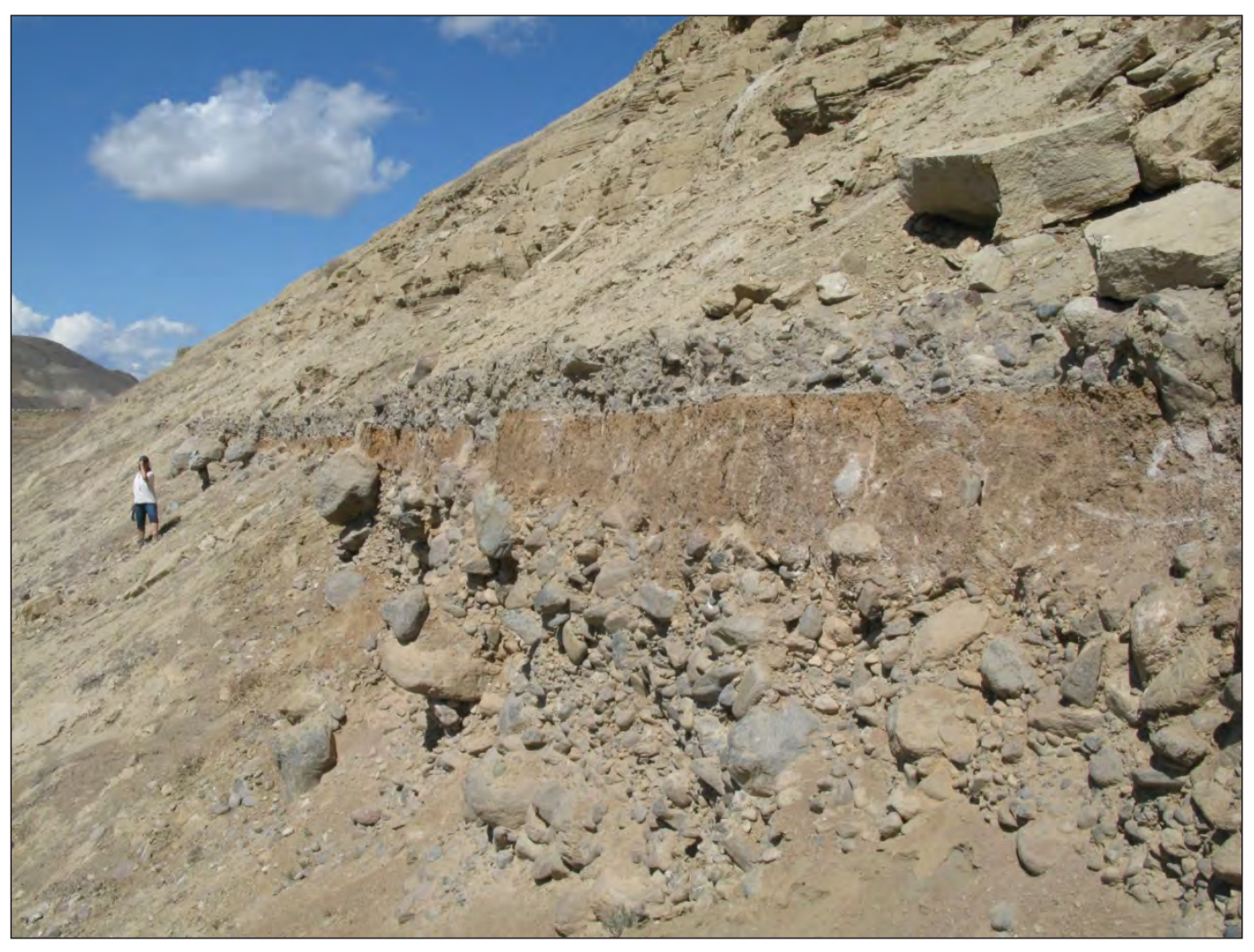

Figure 3.2. The paleosol in the center of the photograph was developed on bouldery fluvial sediments that may represent glacial outburst flood deposits from Lake Tahoe. Photograph by Ken Adams, Desert Research Institute, June 4, 2009. 


\section{Stop 1-2. Tracy exposure (285561 E 4382587 N)}

This exposure consists of thin to medium beds of silty sand capped by alluvial fan gravels (fig. 3.3). Most of the finegrained beds in this section display climbing ripple cross stratification with shallow to steep angles of climb, separated by occasional thin laminae of wave-rippled sands. The steeper angles of climb for the current ripples suggest rapid sedimentation. The wave-rippled units suggest temporary pauses in the overall aggradation of this package when oscillatory wind waves temporarily reworked the surface sediments. A plausible hypothesis is that this section represents a much finer-grained facies of glacial outburst flood deposits than was seen at the first stop, which is about $6 \mathrm{~km}$ upstream and about $5 \mathrm{~m}$ higher in elevation, although no numerical ages are available for either site.

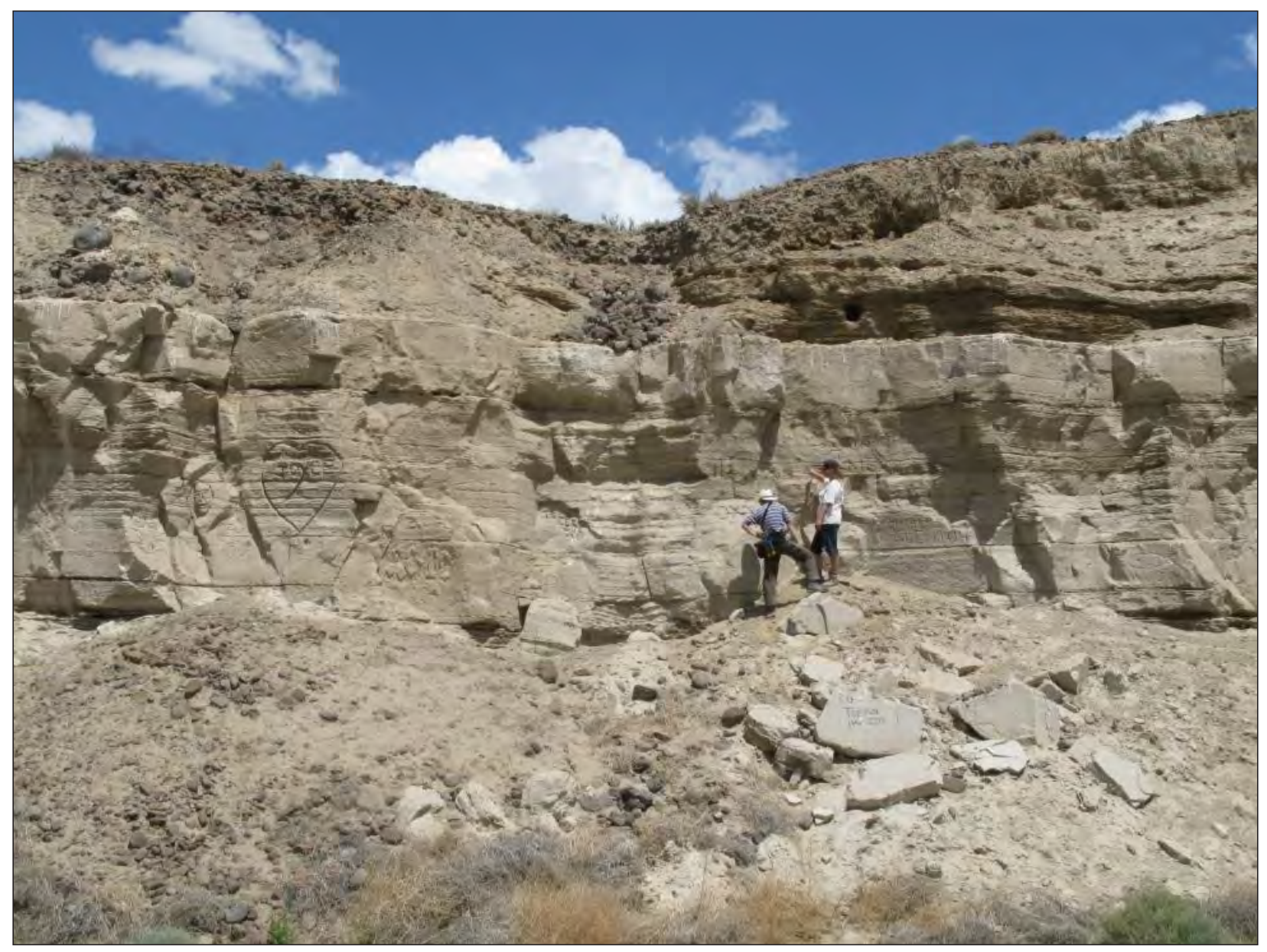

Figure 3.3. Geologists puzzling over the Tracy section. Photograph by Ken Adams, Desert Research Institute, June 4, 2009. 


\section{Stop 1-3. Big Soda Lake (337921 E 4376240 N)}

Big Soda Lake is a well-studied groundwater-fed lake, located near the town of Fallon in northwestern Nevada, USA (fig. 3.4). The lake formed in a volcanic explosion crater that was created sometime in the past 15 ka (Reidy, 2013). It was studied as part of several early surveys in Nevada (King, 1877; Russell, 1885), partly because of its potential economic value (the precipitation of soda salts from the lake waters) and partly because it was one of the few deep permanent water bodies in that area of Nevada (Rosen and others, 2004). At present, the lake is about $1.6 \mathrm{~km}^{2}$ in area and about $61 \mathrm{~m}$ deep (Rush, 1972). Little Soda Lake to the south of Big Soda Lake is a much smaller lake that was dry before 1905 .

The limnology and ecology of the lake were studied by numerous authors throughout the 20th century, but most intensively in the 1980s (Hutchinson, 1937; Breeze, 1968; Cloern and others, 1983; Kharaka and others, 1984; Oremland and others, 1988; and references therein). Before 1907, based on limited data, the lake was thought to be a single, mixed, saline water body (Russell, 1885). When the Newlands Irrigation Project began in 1907, irrigation of farmlands surrounding the lake raised the groundwater table, and consequently the lake level, by $18 \mathrm{~m}$ between 1907 and 1930 (fig. 3.5). This rapid rise in lake level led to chemical and thermal stratification of the lake. The lake's mixolimnion has total dissolved solids (TDS) of about 25,000 $\mathrm{mg} / \mathrm{L}$, and its monimolimnion has a TDS concentration of about 87,000 mg/L (Kharaka and others, 1984).

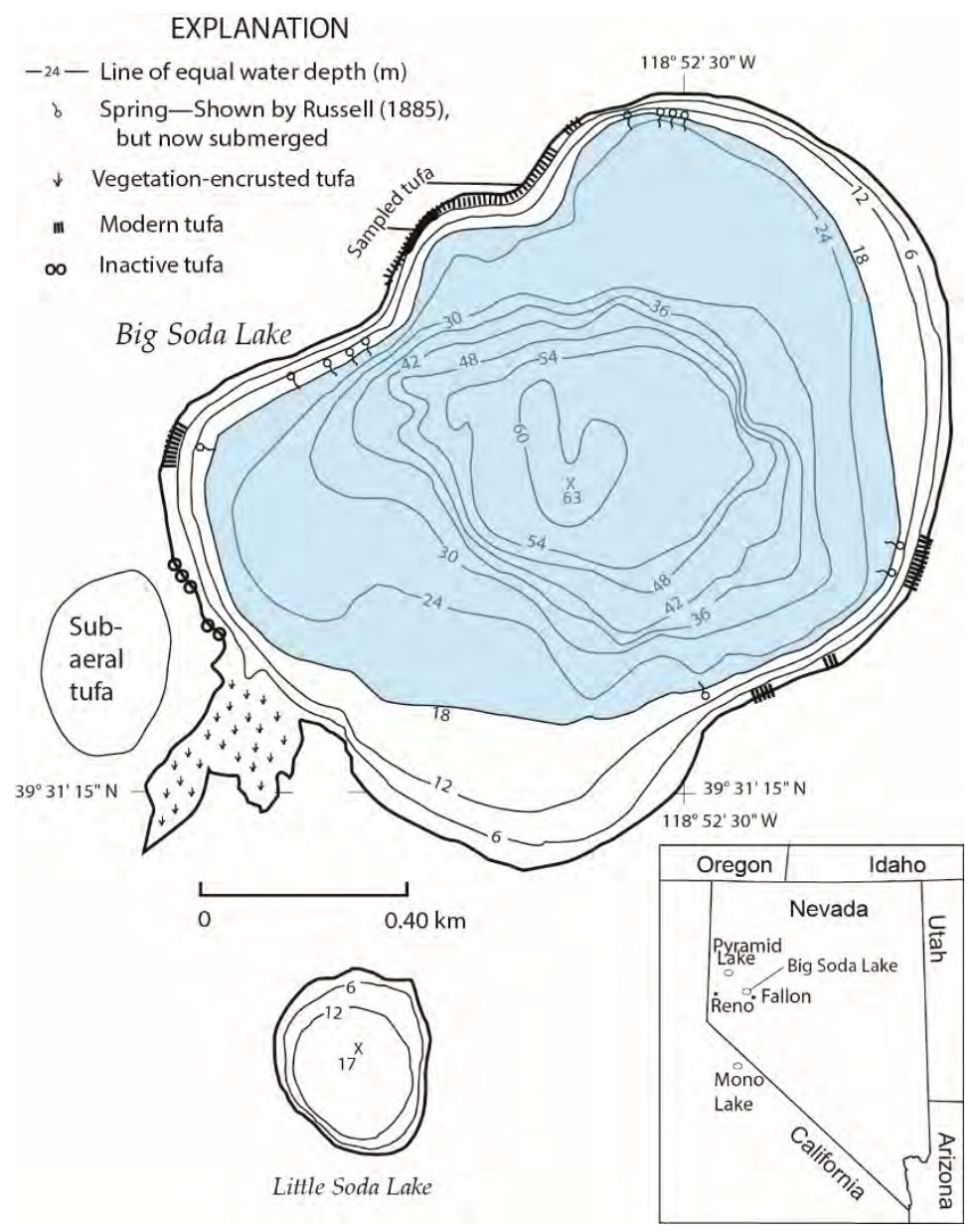

Figure 3.4. Map of Big Soda and Little Soda lakes, near Fallon, Nevada. The blue colored area in the middle of the lake is the area of the lake before 1905. This map is derived from a combination of the map in Russell (1885) and Rush (1972). Modified from Rosen and others (2004).

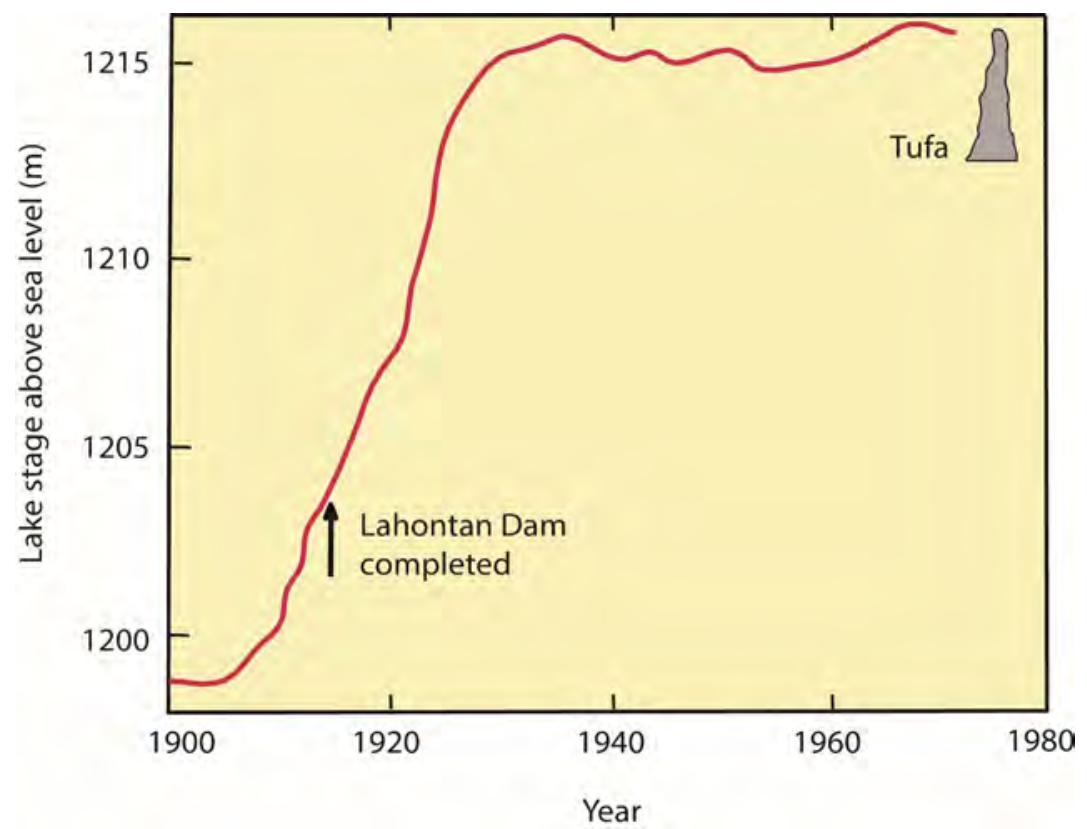

Figure 3.5. Graph showing dramatic rise in lake level after the importation of Truckee River water to Lahontan Reservoir and irrigation of that water onto farmland near Big Soda Lake. Some irrigation and importation of water occurred before Lahontan Dam was completed. The tufa is no more than $4 \mathrm{~m}$ below the current water level, indicating that it formed after the lake level rose to its current position. Data from Rush (1972), modified from Kharaka and others (1984) and Rosen and others (2004). 
The chemocline that separates these two water masses is located at about $35 \mathrm{~m}$ depth. Throughout the depth of the lake, the $\mathrm{pH}$ is about 9.7. The water chemistry of the upper $30 \mathrm{~m}$ of the lake is dominated by $\mathrm{Na}$, and carbonate species, $\mathrm{Cl}$, and $\mathrm{SO}_{4}$, and the average concentrations of these ions are 8,100; 4,100; 7,100; and 5,800 mg/L, respectively. The Ca concentration in the upper $30 \mathrm{~m}$ of the lake is about $5 \mathrm{mg} / \mathrm{L}$, and $\mathrm{Mg}$ and $\mathrm{K}$ concentrations in the upper $30 \mathrm{~m}$ of the lake average 148 and $316 \mathrm{mg} / \mathrm{L}$, respectively (Kharaka and others, 1984).

Rosen and others (2004) examined the position and $\delta^{18} \mathrm{O}$ and $\delta^{13} \mathrm{C}$ isotope chemistry of the tufa that is currently found along the northwestern shore of the lake (fig. 3.6), and determined that it formed after the water level in the lake rose to its current level, because none of the tufa is rooted below $4 \mathrm{~m}$ water depth. Subaerial springs that were noted by Russell (1885) are now underwater and likely provide the calcium that is needed to precipitate the tufa mounds. The tufa is more than $3 \mathrm{~m}$ tall and the circumference of the mounds ranges from about $1 \mathrm{~m}$ around the top to $0.5 \mathrm{~m}$ at the base. Branching is not common, but has been observed in some mounds. The tufa are composed of monohydrocalcite and calcite, with minor amounts of aragonite. The stable isotopic composition of the tufa show that the carbonate precipitated from a combination of groundwater and lake water, and may not be useful indicators of paleoclimate in Big Soda Lake (fig. 3.7).

As water was taken from the Truckee River to the north of the Carson River Basin from 1905 onward, Pyramid Lake level fell and Big Soda Lake level rose. This can be seen in the stable isotopic composition of both lakes (fig. 3.8), showing that even though climate was the same for both lakes, the isotopic composition can change when the hydrology of a basin changes (Rosen, 2015).

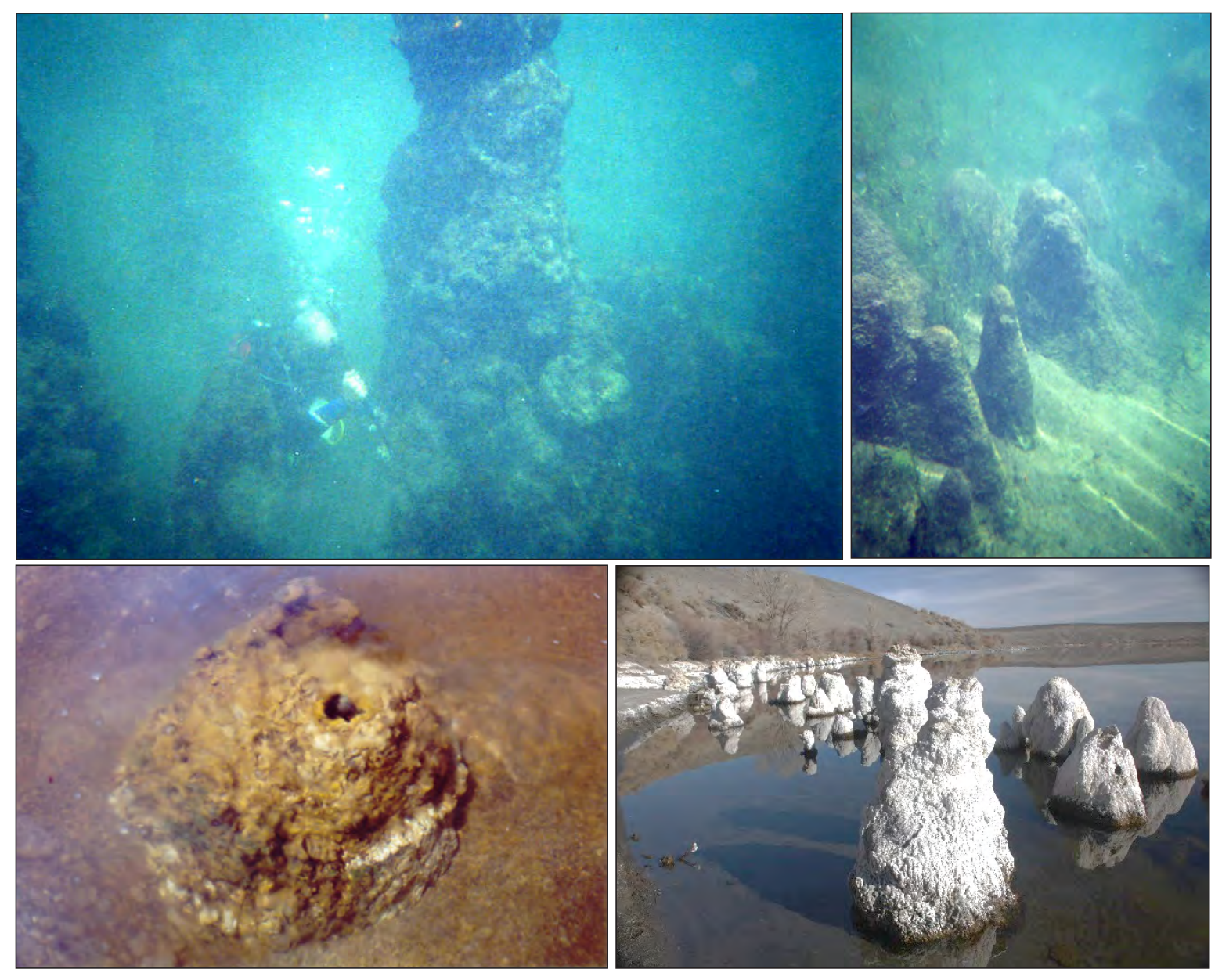

Figure 3.6. Photographs of tufa on the northwestern side of the lake. The upper underwater photographs show the variation of large (diver for scale) to small tufa, and the lower right photograph shows the effect of current drought in the region that is exposing the tops of many of the tufa mounds above lake level. The tufa mound in the lower left photograph, expelling groundwater from its center, is about $40 \mathrm{~cm}$ in diameter and about $30 \mathrm{~cm}$ tall. (All photographs by Michael R. Rosen, U.S. Geological Survey, lower right photograph taken in 2015; other three photographs taken in 2004.) 

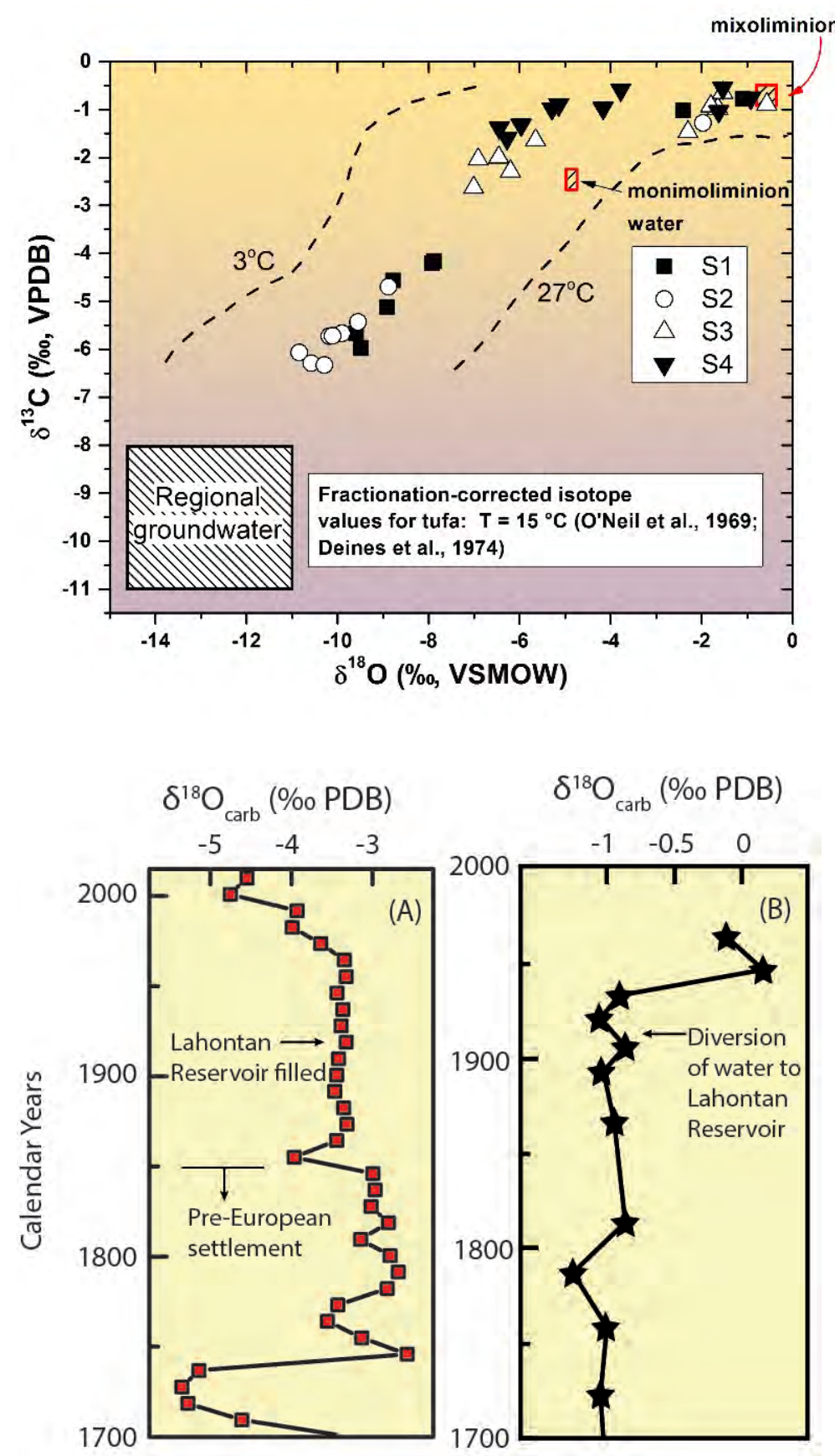

Figure 3.7. Plot of calculated carbon and oxygen isotopes for waters from which tufa carbonate (S1-S4) was precipitated compared to ranges of lake water and regional groundwater isotopic compositions. Dashed lines represent possible minimum and maximum isotopic values for variations in temperatures at time of precipitation. VSMOW - Vienna standard mean ocean water; VPDB-Vienna Peedee belemnite. Modified from Rosen and others (2004).
Figure 3.8. Comparison of the isotopic composition of carbonate precipitated in Big Soda Lake $(A)$ and Pyramid Lake (B). The isotopic composition of Big Soda Lake became more negative as fresher groundwater came into the hypolimnion of the lake, whereas Pyramid Lake carbonates became more positive because of the loss of incoming water and more evaporation because water stopped overflowing to Lake Winnemucca. Data for figure 3.8A are from Reidy (2013) and data for figure 3.8B are from Meyers and others (1998). Modified from Rosen (2015).

\section{Stop 1-4. Hidden Cave (359747 E 4363450 N)}

Hidden Cave is located in the Lahontan Mountains east of Fallon at an elevation of about 1,251 $\mathrm{m}$ and was formed by waves of Lake Lahontan (Davis, 1985). This rather large cave with a tiny opening has attracted visitors since the early Holocene who have left behind basket fragments, twine, and tools that they used to exploit the animal and plant resources of nearby wetlands or lakes in the Carson Sink (Rhode and others, 2000). Our guide from the Churchill County Museum will give us a private tour of this beautifully excavated archaeological site.

\section{Stop 1-5. Grimes Point (358152 E 4362613 N)}

Grimes Point is located about $2 \mathrm{~km}$ southwest of Hidden Cave at the western tip of the Lahontan Mountains. Here there are abundant petroglyphs pecked into basaltic boulders distributed along crude shoreline terraces formed by waves of Lake Lahontan. The age of the petroglyphs is not known so temporal associations with lake levels cannot be made with certainty, but it is tempting to envision Native Americans lounging amongst the rocks idly pecking away after a nice swim or clam bake.

We will spend the night in Fallon. 


\section{DAY 2. Fallon to Hawthorne}

\section{Stop 2-1. Salt Wells Beach Barrier (359233 E 4361079 N)}

The Salt Wells beach barrier is located on the southern side of the Lahontan Mountains about $2 \mathrm{~km}$ to the southeast of Grimes Point (fig. 3.9A) at an elevation of about 1,200 m. This feature was first identified as a beach ridge by Morrison (1964) who designated it as the Fallon 1 shoreline with an estimated age of 2-4 ka. Davis (1978) identified one of the Mono Craters tephras, locally known as the Turupah Flat bed, within the feature and surmised that the maximum age of the shoreline was constrained to be less than about 2 ka. Adams (2003) observed that the north-dipping tephra crops out continuously for a distance of at least $1.5 \mathrm{~km}$ along the southern or lakeward face of the beach ridge and dated charcoal fragments found directly beneath the tephra in undisturbed laminae to $810+70 \mathrm{yr}$ BP (660-910 cal yr BP) (fig. 3.9B).
A lake with a surface elevation of about 1,200 $\mathrm{m}$ has a surface area of about 2,800 $\mathrm{km}^{2}$ and a volume of about $37 \mathrm{~km}^{3}$ (Adams, 2003), which constitutes a very large lake in the normally dry Carson Sink. Adams (2008) used moisturesensitive tree ring chronologies from the North American Drought Atlas (NADA) (Cook and others, 2004) to suggest that the wet period associated with this lake occurred around $850 \mathrm{cal}$ yr BP or at about 1100 A.D, which falls right between two long duration Medieval droughts (Stine, 1994). In the most recent update to the NADA, Cook and others (2010) indicate that the Medieval pluvial period lasted for 46 years from 1075 to 1121 A.D. The duration and magnitude of this pluvial episode provides a stark example of how rapidly these hydrologic systems can respond to seemingly minor climate changes (Adams, 2013).

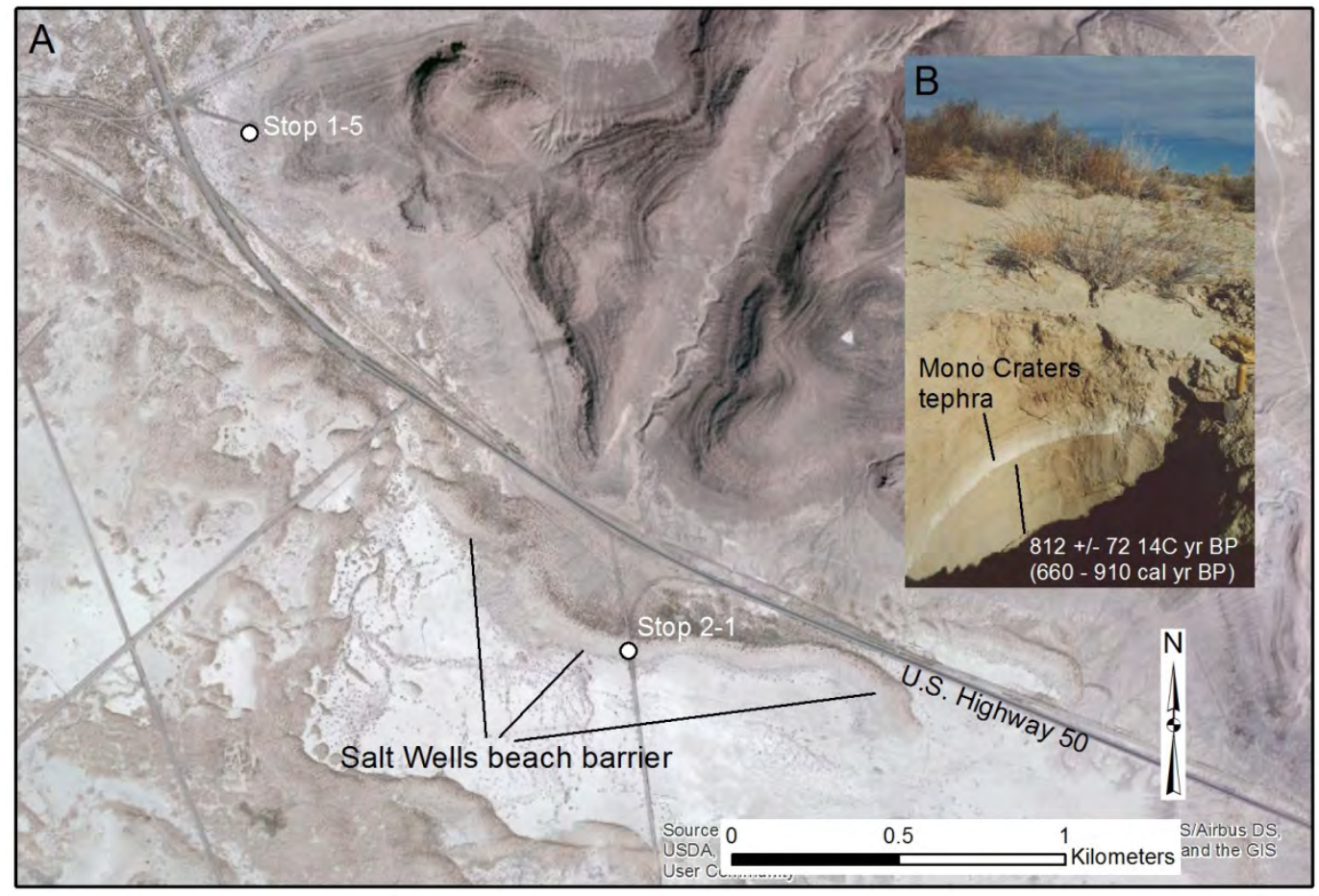

Figure 3.9. A. Aerial image of the Salt Wells beach barrier (Stop 2-1) and Grimes Point areas (Stop 1-5). Image from USDA National Agriculture Imagery Program, July 21, 2013. B. Photograph of pit excavated on the lakeward side of the beach ridge that shows the north-dipping tephra. Photograph by Ken Adams, Desert Research Institute, May 15, 2002. 


\section{Stop 2-2. Bunejug Spit (359462 E 4359044 N)}

The Bunejug spit was built off the northern end of the Bunejug Mountains by waves traveling from the west-southwest across the southern Carson Desert when lake levels ranged from about 1,205 to $1,215 \mathrm{~m}$. Although lake levels have probably fluctuated through this elevation range numerous times over several lake cycles, the Wono tephra is found within beach gravels in the core of this feature (fig. 3.10) indicating that lake level was at about 1,205 $\mathrm{m}$ around $27 \mathrm{ka}$ when the Wono tephra was deposited (Adams, 2010).

It is interesting to note that the Salt Wells beach barrier is at about the same elevation as the Wono tephra in this outcrop and both features represent lakes of similar size. Sediments of the Bunejug spit, however, are much coarser with some of the basaltic boulders ranging up to greater than $1 \mathrm{~m}$ in diameter. The closest bedrock is thought to be greater than $1 \mathrm{~km}$ to the south, which makes the wave transport of these boulders all the more impressive. One hypothesis to explain the presence of boulders in this outcrop is that their transport was aided by the presence of lake ice, but this remains to be tested.

\section{Stop 2-3. Russell Spit (348431 E 4343760 N)}

Russell Spit (fig. 3.11A, 3.11B) was named by Roger Morrison (1964) in honor of Israel Russell, who conducted the first complete study of Lake Lahontan (Russell, 1885). Russell interpreted the height and arrangement of spits here to indicate that the younger of the two major lake cycles (Sehoo Lake cycle) reached a level 1-2 m higher than the penultimate lake cycle (Eetza Lake cycle). Morrison (1964) disagreed with this interpretation and suggested that the Eetza Lake was represented here by the highest shoreline (Spit A in fig. 3.11B). Regardless of which lake cycle reached a slightly higher elevation than the other, it is very interesting that two distinct lake cycles, separated by more than 100,000 years in time would reach to just about the same elevation in a basin without an outlet.

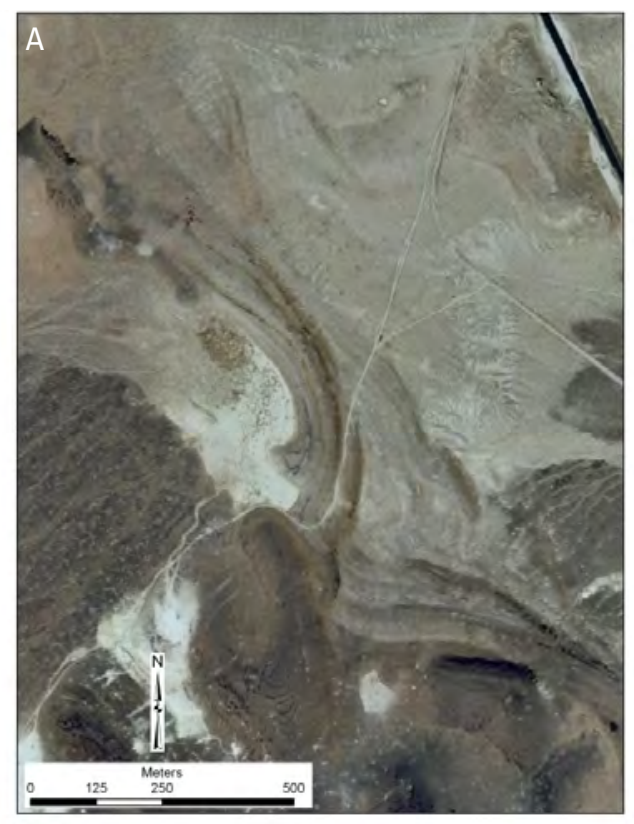

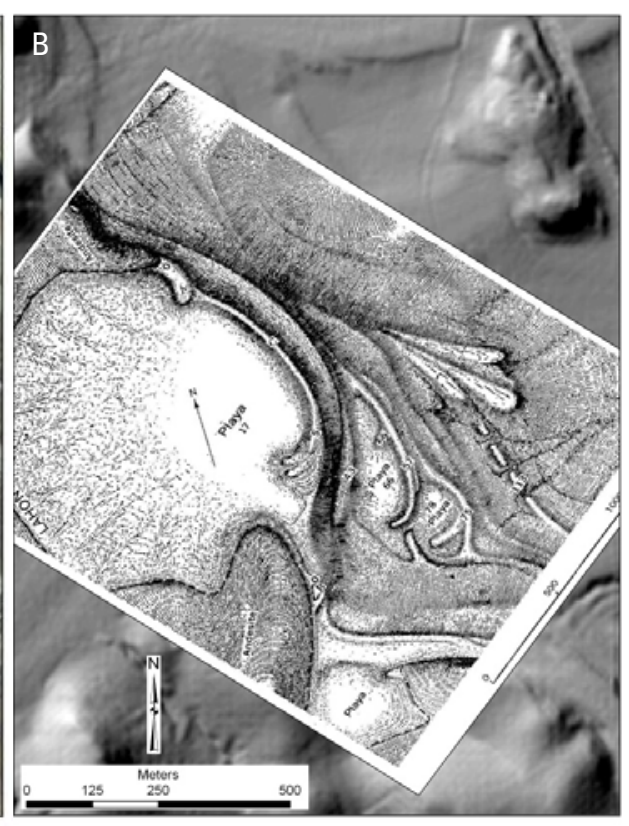

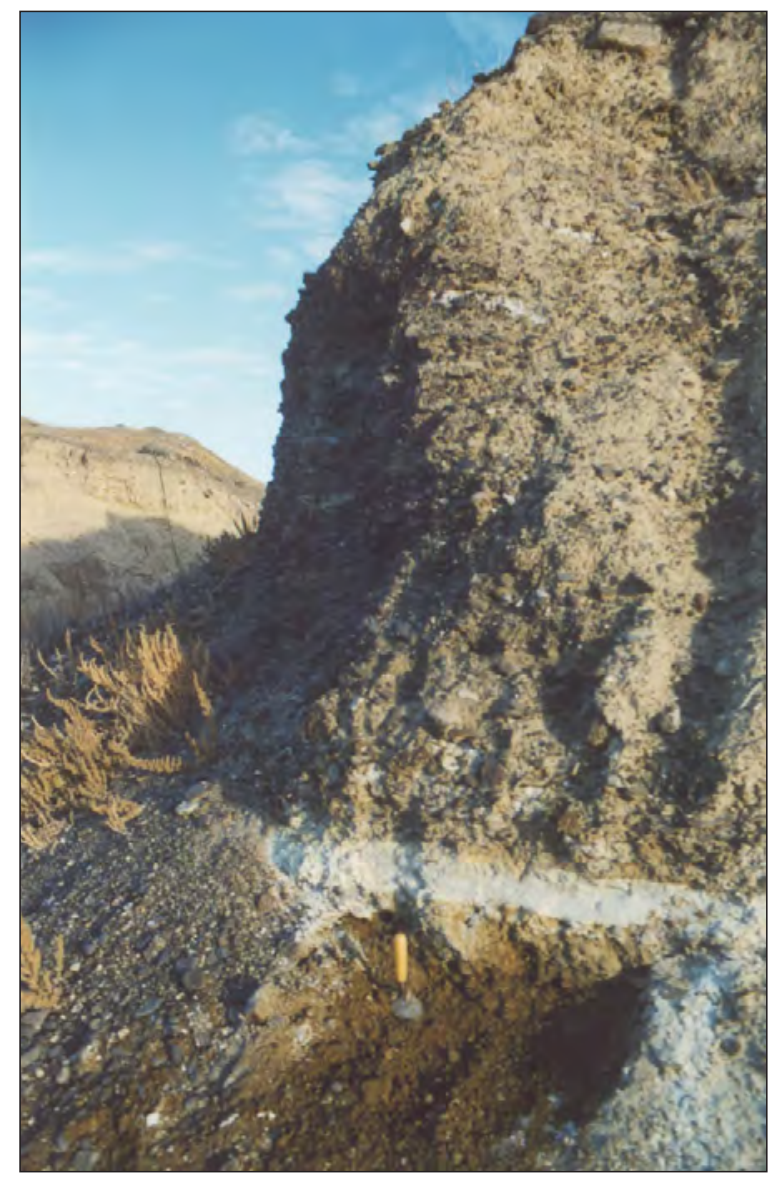

Figure 3.10. At the Bunejug Spit, the Wono tephra crops out at an elevation of about 1,205 $\mathrm{m}$ in coarse beach deposits. Photograph by Ken Adams, Desert Research Institute, May 15, 2002.
Figure 3.11. Two views of Russell Spit, the first of which $(A)$ is a satellite image draped over a lidar hillshade and the second of which (B) is Russell's field map from 1885. Image $A$ is from USDA National Agriculture Imagery Program, July 21, 2013. Image B is line drawing from Russell (1885); lidar data from U.S. Geological Survey (2005). 


\section{Stop 2-4. Butt Bend (345565 E 4310141 N)}

You are now in the Walker Lake subbasin of the Lake Lahontan basin (fig. 3.12), which was only connected to the rest of the Lahontan system when the lake was at relatively high elevations ( $>1,310 \mathrm{~m})$. At this location, a Mono Craters tephra can be directly traced from fluvial deposits of the Walker River downstream into shallow lacustrine deposits of Walker Lake over a distance of a few hundred meters (Adams, 2007). The age of charcoal collected from directly beneath the tephra indicates that the lake was rising through an elevation of about 1,252 m around $760+40{ }^{14} \mathrm{C}$ yr BP $(650-780 \mathrm{cal} \mathrm{yr}$ $\mathrm{BP})$. This age range overlaps with the age range of the tephra found in the Salt Wells beach barrier (Stop 2-1), which suggests they might be the same tephra and that both the Walker Lake and Carson Sink subbasins held relatively large lakes during the Medieval pluvial around 1100 A.D.

\section{Stop 2-5. Walker Lake Holocene highstand (344382 E $4309386 \mathrm{~N})$}

A group of constructional beach ridges ranging in elevation from about 1,255 to 1,260 m represent late Holocene lake levels at Walker Lake, which are 5-10 m higher than the historical highstand of about 1,250 m (Adams, 2007). The highest of these shorelines (about 1,260 m) date to the neopluvial period around $3700 \mathrm{cal}$ yr BP, when the lake was sill controlled (Adams and others, 2014). These new ages are helping to refine the radiocarbon-based lake-level curve of Adams (2007).

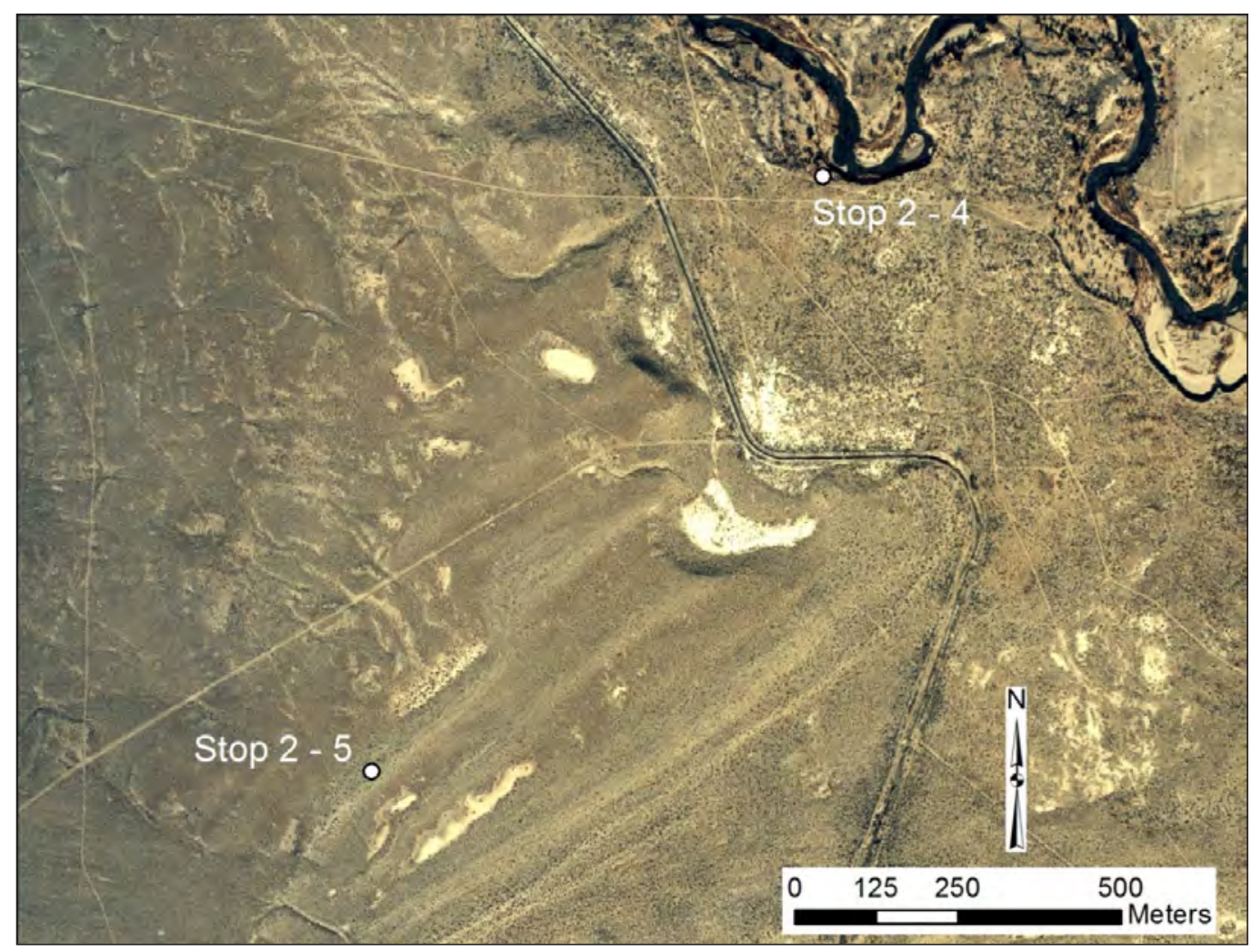

Figure 3.12. Aerial photograph from Great Basin Aerial Surveys showing locations of Stops 2-4 and 2-5. Image taken December 2, 1997. 


\section{Stop 2-6. Copper Canyon (346063 E 4289178 N)}

Copper Canyon drains the eastern side of the Wassuk Range above Walker Lake and has a variety of interesting features. The late Pleistocene highstand shoreline of Lake Lahontan is well developed on the mountain front here as are the late Holocene sequence of shorelines at lower elevations. Between these two periods, abundant alluvial fan deposition has covered the piedmont, which has subsequently been faulted by the Wassuk Range front fault system (Wesnousky, 2005). The Copper Canyon alluvial fan has also been very active of late with debris flows exiting the canyon mouth and flowing to the lake in 1982, 1990, and most recently in 2014 (fig. 3.13).

We will spend the night in Hawthorne.

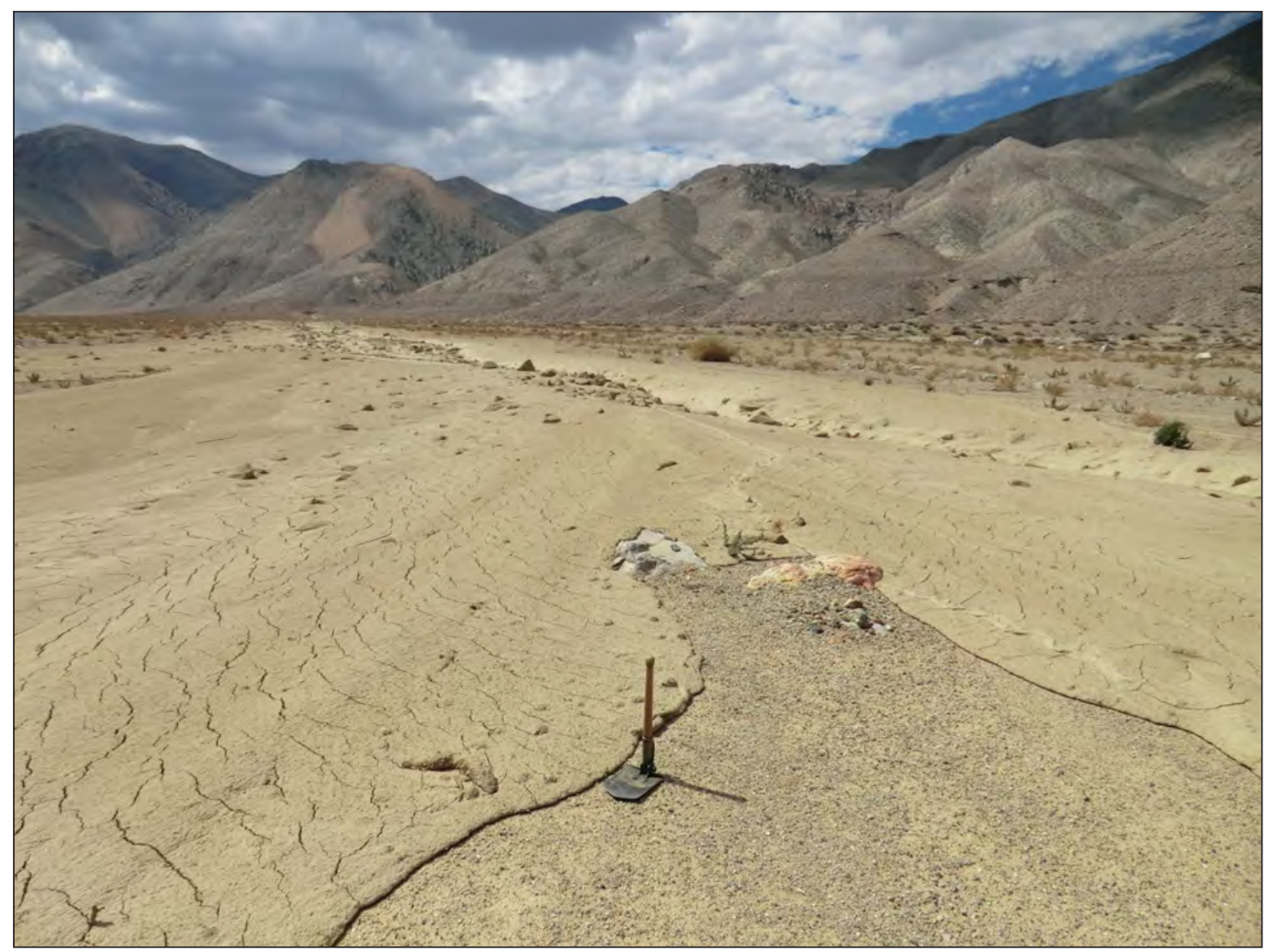

Figure 3.13. Clast-poor debris flow deposits on the Copper Canyon alluvial fan that were caused by an intense thunderstorm in the headwaters of this drainage in August 2014. Photograph by Ken Adams, Desert Research Institute, September 15, 2014. 


\section{DAY 3. Hawthorne to Lee Vining}

As we approach the California-Nevada border, we enter the lake plain of the highest Pleistocene Lake Russell, where Cedar Mountain, to the right (north) was an island. It bears the shorelines of past highstands and recessions, and is surrounded by deep-lake sediments, consisting of Sierran glacial flour and eruption products of the rhyolitic Mono Craters. Crossing the plain, we cut diagonally across the North Mono dune field toward the Holocene shorelines and Black Point.

\section{Stop 3-1. County Park (311256 E 4209733 N)}

Mono Lake County Park sits in the northwest quadrant of the lake shorelands, where Dechambeau Creek enters the lake. A boardwalk leads toward the lake, beginning just above the 1919 historical highstand of $1959 \mathrm{~m}$ and leading through marshlands and tufa towers. With the beginning of intense diversions by Los Angeles Department of Water and Power (LADWP) in 1941, the lake level began declining precipitously, reaching its historical lowstand in 1982, at 1,942.3 m above sea level (masl; fig. 3.14). After a long citizen-led campaign, legislation was passed in 1994 setting limits to water diversions, in order to restore and maintain the natural ecosystems of Mono Lake. Between 1994 and 1998, the lake rose $3 \mathrm{~m}$, and has fluctuated between 1,945 and 1,946 masl since then; the target level for the long-term is 1,947.9 masl (legally, 6,391 ft). The lake level has declined more than $1 \mathrm{~m}$ in the last 3 years of exceptional drought, and officially stood at just 1,944.32 m (6,379.01 ft) on April 1, 2015 , triggering a 70 percent reduction in water exports to Los Angeles.

The tufa towers along the boardwalk were all submerged until at least 1960 . They provide examples of the variety of tufa forms described by Russell (1889), Dunn (1953), and Scholl and Taft (1964), including triangular flanges with flat bottoms marking the level of the lake when the flanges were formed by mixing of spring and lake waters (fig. 3.15).

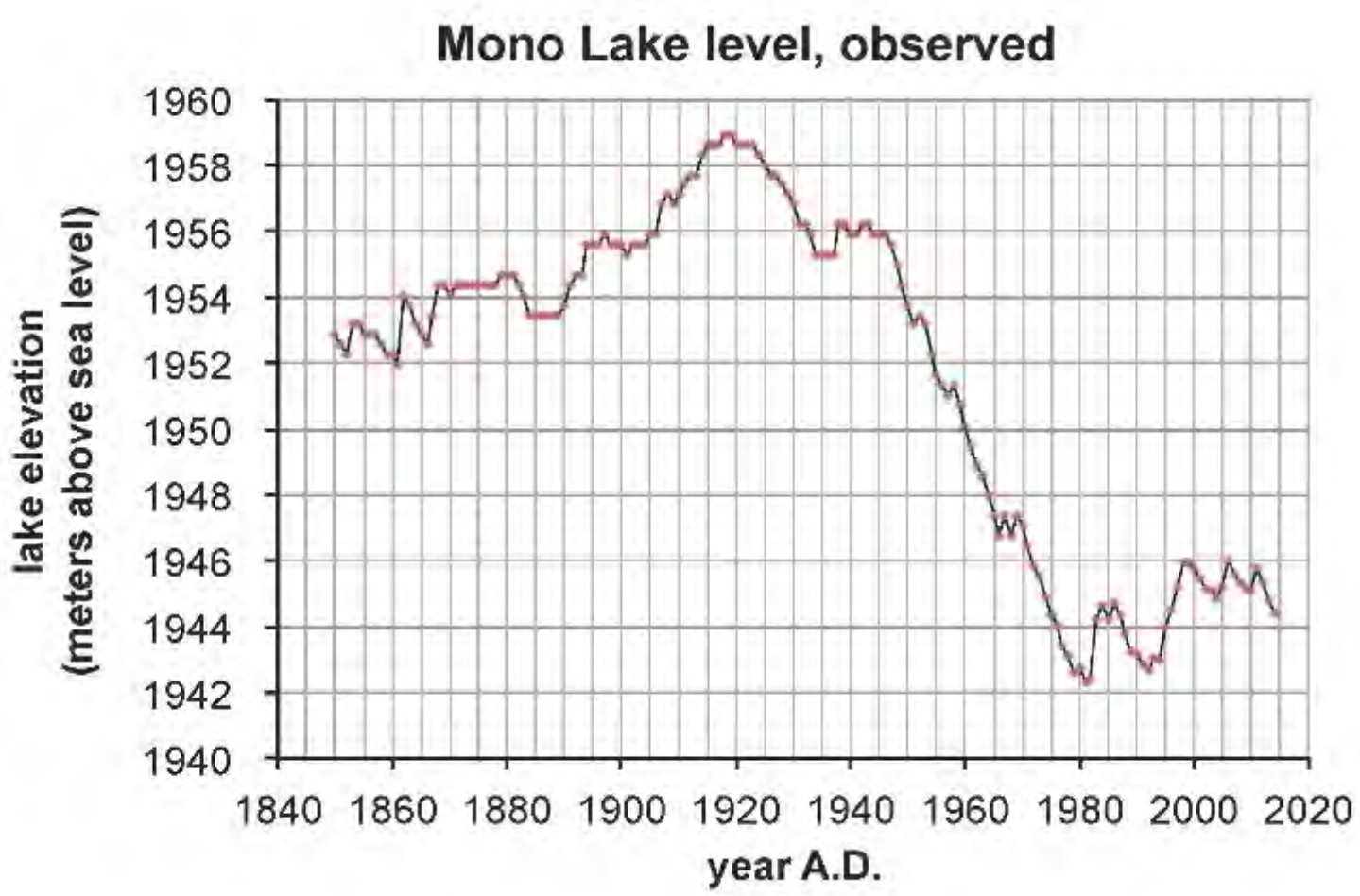

Figure 3.14. Record of Mono Lake level over the observational period (data courtesy of Mono Lake Committee at http://www.monobasinresearch.org). Period 1850-1911 reconstructed by Stine (1987); 1912-1979 from LADWP and USGS compilations; since 1979 from LADWP and Mono Lake Committee observations. 


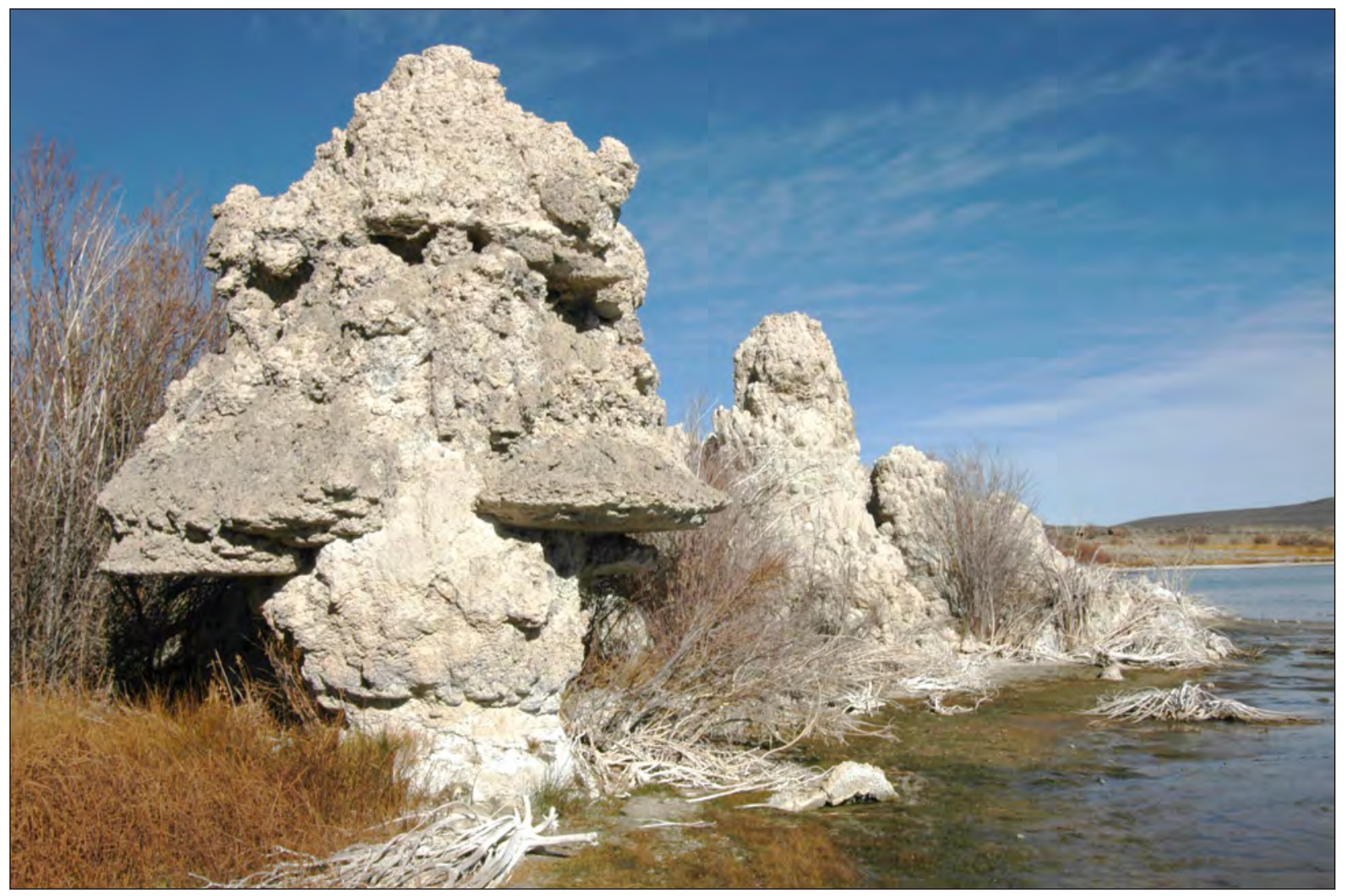

Figure 3.15. Holocene tufa towers along the northwestern shore of Mono Lake, showing multiple generations of tufa formation. (Photograph by S. Stine, date unknown.)

Looking from left (east) to right (west) at the end of the boardwalk, we see the bright white delta of Mill Creek, formed by Pleistocene glacial flour eroded by the stream on its path from Lundy Canyon to the lake. Next to it is the modern delta of Wilson Creek, similarly composed of eroded glacial flour, but green because much of the natural flow of Mill Creek is diverted to Wilson Creek. Just beyond is the flat-topped basaltic Black Point, which erupted under the lake near the end of the last glacial period. Looking south at the lake, Paoha Island was uplifted by magmatic intrusion domed up less than or equal to 300 years ago (Stine, 1990), and is formed of gray/white lake sediments with small pockets of dacitic and rhyolitic material. Hot springs hosting highly unusual arsenic-loving microbial communities are on Paoha Island (Kulp and others, 2008; Wolfe-Simon and others, 2011). Across the lake to the south are the Mono Craters and the (now-exposed) Pleistocene deltas of Rush Creek and Lee Vining Creek, and to the west is the Sierran front. Behind us lies the northernmost glacial canyon in the basin, Lundy Canyon, with the mouth flanked by towering moraines. 


\section{Stop 3-2. Grand Gash (311364 E 4210797 N)}

Grand Gash is an artificial cut nearly perpendicular to past shorelines, and gives an interesting peek into the stratigraphy under this part of the basin, and its relations to the Pleistocene lake terraces and tufa towers. Here we find tufa towers aligned more or less along the 2,020 m elevation, the nickpoint of the lower elevation Pleistocene terrace. The towers along this line are dominated by thinolite (fig. 3.16), identified by Russell (1889) and Dana (1884) as a pseudomorph after an unknown mineral. Shearman and others (1989) identified the precursor as ikaite, a hexahydrated calcium carbonate mineral thus far found only in extremely cold marine or estuarine settings, which decomposes at surface temperatures. Ikaite was first observed forming along the south shore of Mono Lake by
Bischoff and others (1993) and Council and Bennett (1993) in the mixing zone of sublacustrine spring water and lake water, at cold temperatures. Very still waters (Bischoff and others, 1993) and the high levels of orthophosphate in Mono Lake (60 mg/L, Mason, 1967) seem to be conducive to ikaite formation, suggesting that the Pleistocene thinolite may hold paleoenvironmental information. It is notable that thinolite is common in the last-glacial Wilson Creek Formation (WCF) sediments near the uppermost tephra, associated with the final highstand during the deglacial period, but apparently nowhere else in the stratigraphy. Where this part of the WCF is near the surface, thinolite heads and mounds occur on the surface, and often can be traced to thinolite crystals precipitated within the sediment itself (fig. 3.17).
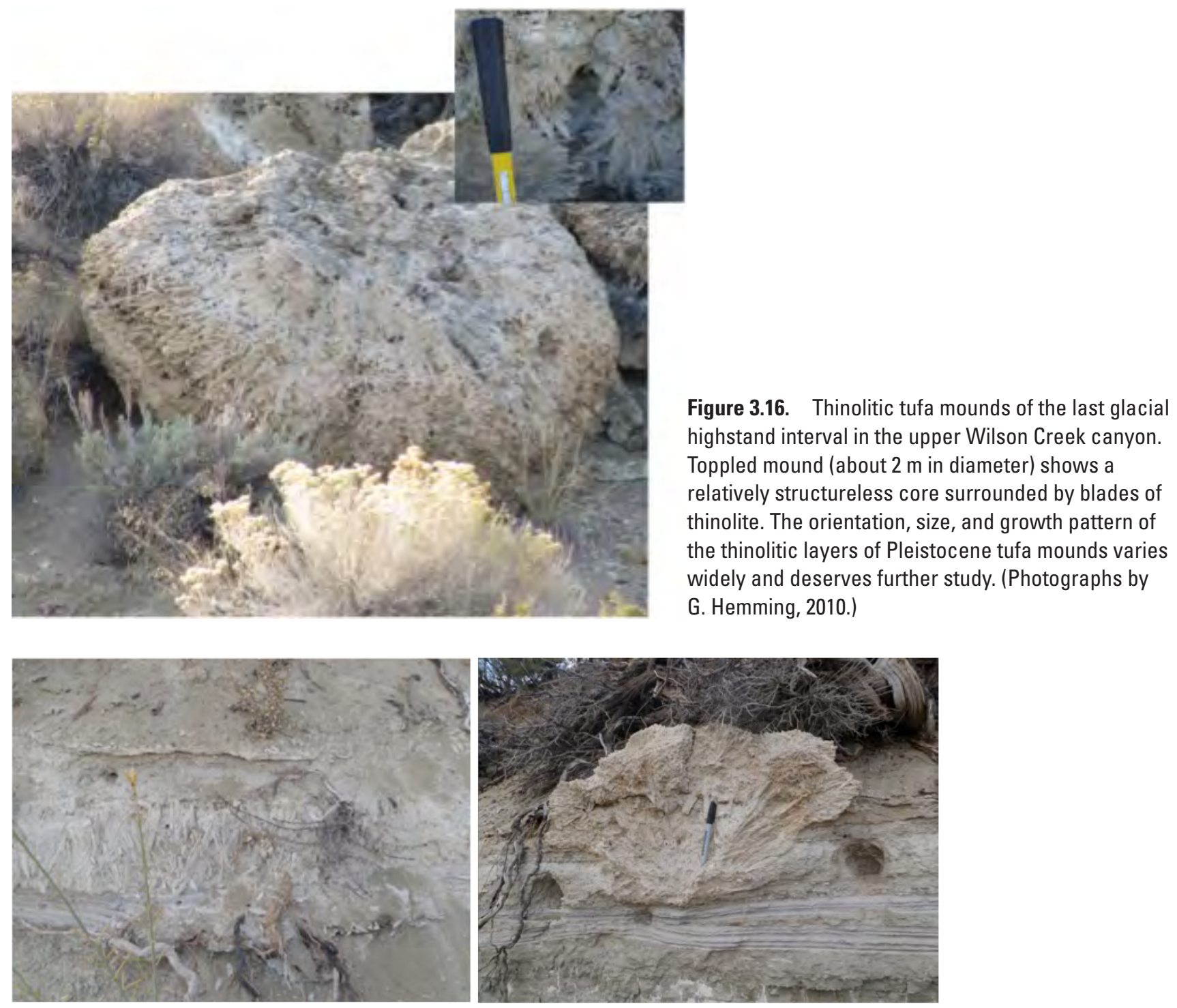

Figure 3.17. Thinolite in the Upper Wilson Creek section (about 2,030 masl). Thinolite crystals can be observed growing within the sediment just above Ash 1, in some places without expression as a mound (left) and in other places extending above the paleo-lake floor as a mound or fan (right). (Photographs by X. Wang, 2010.) 


\section{Stop 3-3a. South Tufa (321907 E 4200955 N)}

One of the most dramatic and popular sights at Mono Lake is the groves of tufa towers rising out of the lake, especially the grove at South Tufa (fig. 3.18). The tufa towers here are highly unusual in the Mono basin, in that they have no layering to speak of, and are composed only of Russell's lithoid tufa. Although much of what we see at South Tufa was underwater in 1883, Russell aptly described the tufa in this part of the basin as "a forest of gnarled and contorted trunks and stumps changed to stone” (Russell, 1889).

The towers were chemically precipitated underwater around the numerous springs, and those along the modern shoreline were exposed during the lake level decline of the mid-20th century. The towers here are also unusual in being relatively young, with only a thin bulwark of sediment around the base. The erosion of that sediment during the transgressions of the last few decades has resulted in an unusually high rate of toppling of towers (Stine, 1991). Look for markers along the boardwalk identifying the elevations of the lake shoreline through the recession. At the shoreline, the underwater springs create a chatoyancy, or shimmering, in the lake, where fine carbonate crystals are forming as the fresh, Ca-bearing water mixes with the $\mathrm{CO}_{3}$-rich lake water. Look carefully and you may find fresh crystals massing on tufa, a twig, or other hard surfaces.

Herbst (1990) demonstrated that those hard substrates, especially the tufa and beachrock themselves, are the favorite habitat of the larvae of the alkali fly Ephydra hians. The adults are non-biting flies and often form a thick black ring in the first meter or so of shoreline above the lake. The adults use their claws to "walk" down the tufa underwater, to feed and to deposit eggs. Once hatched, the larvae feed on the algal mat communities on the tufa, and use their claws to remain attached to the tufa. E. hians larvae may also contribute to the tufa, in the form of calcium carbonate spherules described by Herbst and Bradley (1989). The spherules form in a special gland in the larvae designed to regulate the highly alkaline lake water all around the organism. The adult flies are a major food source for the migratory birds that pass through the basin every year, stopping to fatten up, such as eared grebes and phalaropes. The Mono Islands are a major breeding site for California gulls, and osprey can be spotted nesting on the towers themselves, flying off to the fresh mountain lakes to fish.
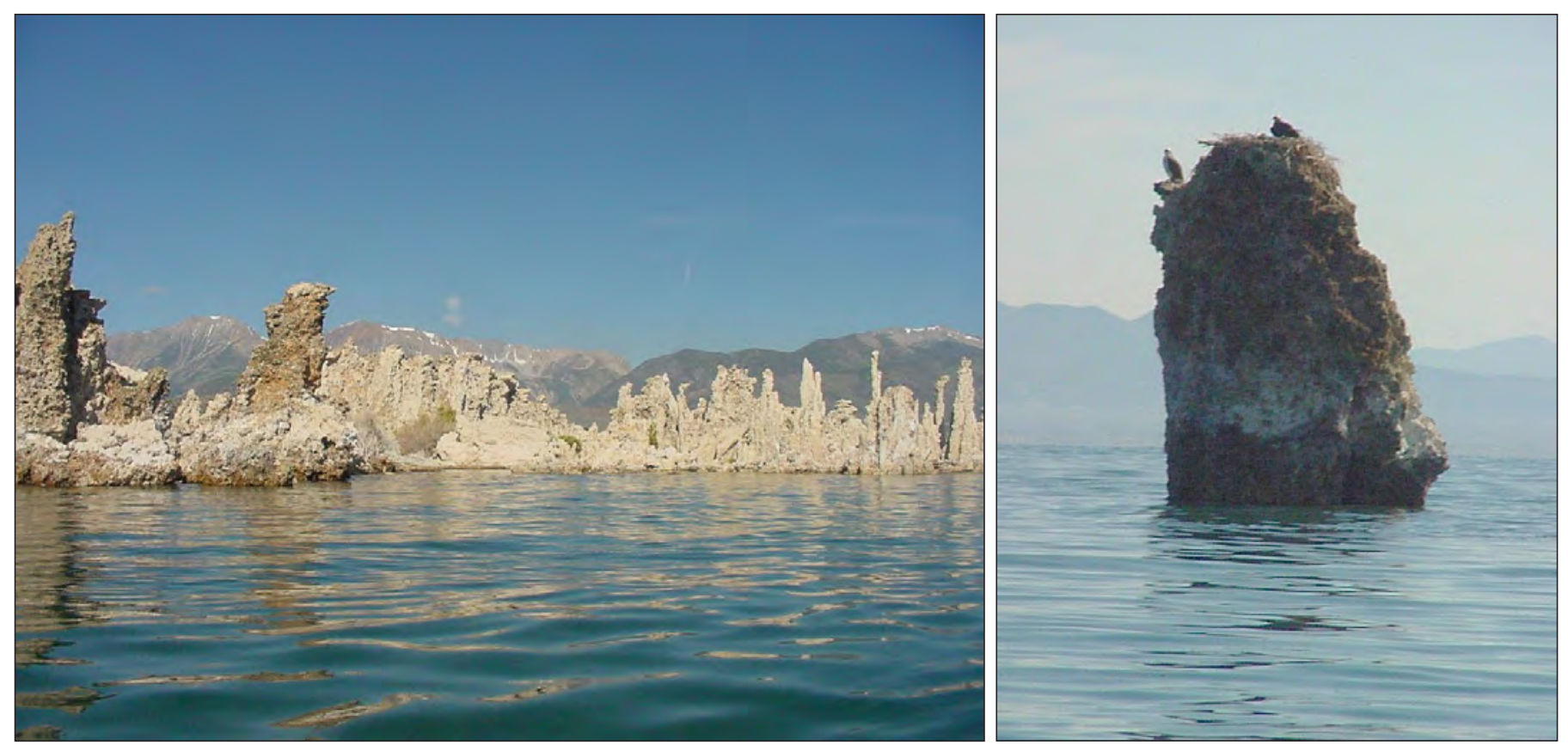

Figure 3.18. Tufa towers at South Tufa are one of the most dramatic and popular sights at Mono Lake. In some cases, osprey can be seen nesting on the towers (right). (Photographs by S. Zimmerman, 2001.) 


\section{Stop 3-3b. Navy Beach (321907 E 4200955 N)}

Navy Beach holds two particular objects of interest: volcanically fed hot springs and sand tufa (fig. 3.19). Sand tufa forms beautiful pipes and columns along the beach face, in many cases preserving the sedimentary structures and layering of the sand. Sand tufa was shown by Cloud and Lajoie (1980) to be another variety of tufa precipitated by the mixing of lake water and freshwater. In this instance, the freshwater flows as shallow groundwater from higher elevations, and meets the lake water along the shore, in the highly porous pumice-rich sands. The freshwater rises buoyantly up through the sands to float on top of the lake water, and at the zone of mixing carbonate cement is formed. Although the process must take place below the ground surface or lake bottom, the lake-level decline in the decades between 1941 and 1980 exposed the lake bottom and allowed the uncemented sand around the columns to be blown away, exposing the sand tufa. Cloud and Lajoie (1980) argue that chemical precipitation easily explains the formation of the sand tufa, and Souza-Egipsy and others (2005) use Scanning Electron Microscope and other microscopic techniques to describe bacterial communities inhabiting the sand tufa, and the possibilities for detecting similar communities in the fossil record.

Oremland and others (1987) examined a number of springs and seeps, and the lake sediments themselves, to understand the processes producing methanogenesis in the Mono Lake basin. In that study, they found that the hot spring at Navy Beach was unique in having very small amounts of methane (0.02 percent) and high $\mathrm{CO}_{2}$ (68 percent) compared to the other locations studied (60-80 percent methane and $<1$ percent $\mathrm{CO}_{2}$ ). The ${ }^{14} \mathrm{C}$ content of the gases from the spring was also quite low. They interpreted these findings to indicate that the Navy Beach hot spring tapped volcanic sources, whereas other seeps and springs were dominated by modern biologic activity.

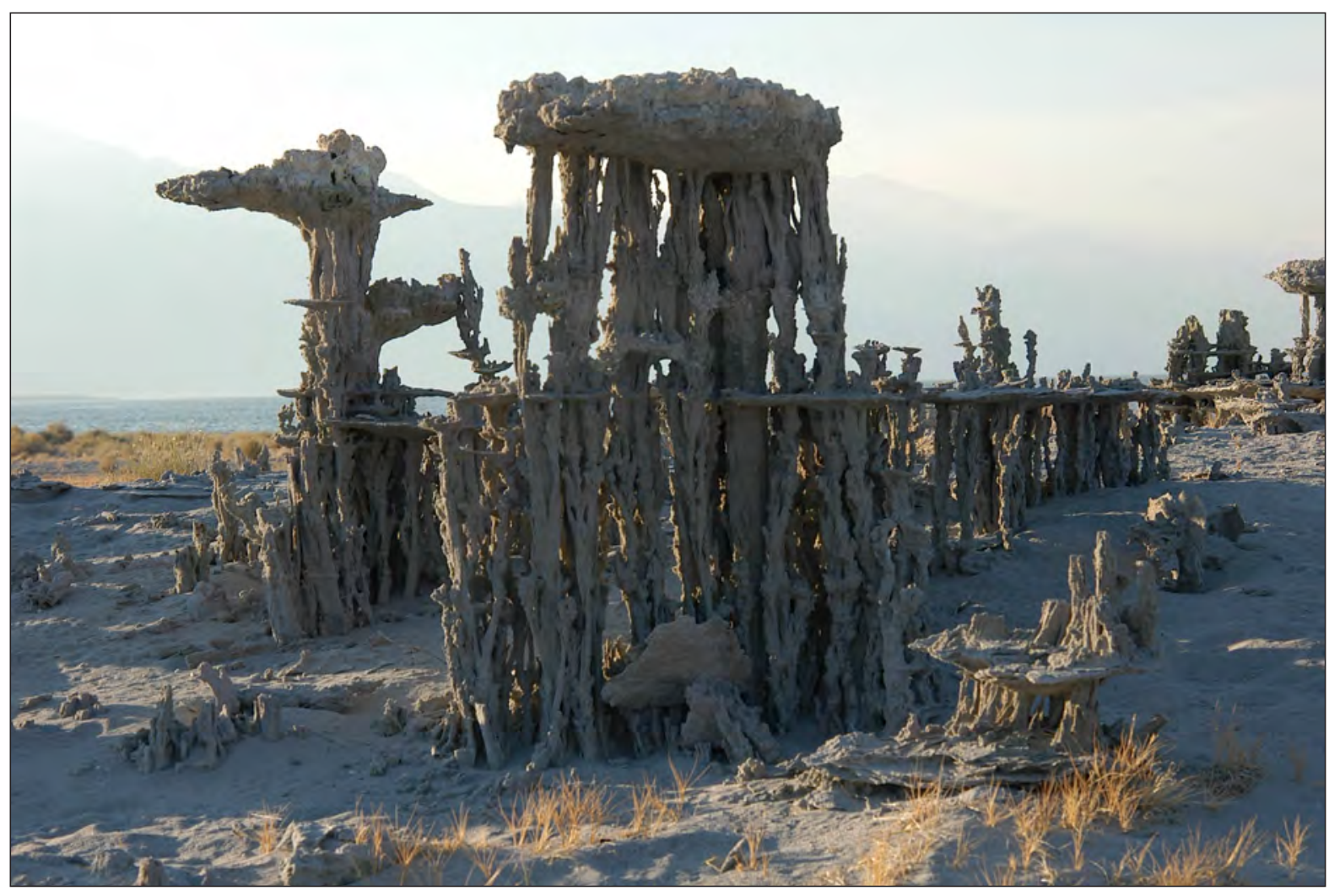

Figure 3.19. Sand tufa exposed near Navy Beach, by historical lake-level decline since 1941. Pipes and columns form within the sediment, by freshwater rising through sediment saturated by dense, alkaline lake water. (Photograph by S. Stine, date unknown.) 


\section{Stop 3-4. Panum Crater (320690 E 4199026 N)}

Panum Crater is the youngest and northernmost of the Mono-Inyo Craters, an arcuate line of explosion craters, domes, and coulees extending from the northern boundary of Long Valley Caldera nearly to the lakeshore (Hildreth, 2004). The craters are dominantly high-silica rhyolite, with one dacite dome in the northwestern part of the chain (Kelleher and Cameron, 1990). They are presumed to be the source of the Wilson Creek Formation tephras, whose glass majorelement chemistry is indistinguishable from that of the craters. Recent work by Vazquez and others (2013) and Marcaida and others (2014) has begun to connect WCF tephras with specific eruptions of the Mono Craters based on their titanomagnetite geochemistry, supported by U-Th dating of allanite and zircons (Vazquez and Lidzbarski, 2012; Vazquez and others, 2013). A puzzle that remains to be solved is the apparent imbalance between the age of the tephras, which range from about 17 to about $65 \mathrm{ka}$, and the apparent age of the craters, mostly younger than $20 \mathrm{ka}$, and none so far found to be older than 25 ka.
Panum Crater itself is a product of the North Mono-Inyo eruption (fig. 3.20), the last of the major tephra-forming eruptions. Radiocarbon dating of vegetation charred by the eruption gives an age of 600-625 cal yr BP (Sieh and Bursik, 1986; Bursik and Sieh, 2013). The North Mono-Inyo eruption also formed several other volcanic features, and produced a tephra that is found at least as far away as Walker Lake (100 km northeast) (Sieh and Bursik, 1986). The northern side of the crater is formed by a block-and-ash flow (Sieh and Bursik, 1986) that shows the Little Ice Age highstand level particularly well, in the form of a steep, wave-notched cliff with its base at 1,967.7 masl (Stine, 1990). The vegetation below that elevation is much different from that above, as described by Stine (1990), because of the residual salts and high $\mathrm{pH}$ within the surface sediment. Similar boundaries occur at about 1,959 masl, below which the land has been exposed only since 1919, and at about 1,980 masl, the highest Holocene shoreline. Above that elevation, the land has been exposed for more than 4 kyr, probably since about 10-12 ka.

We will spend the night in June Lake.

This is an area of active research, and exciting advances are anticipated in the coming years.

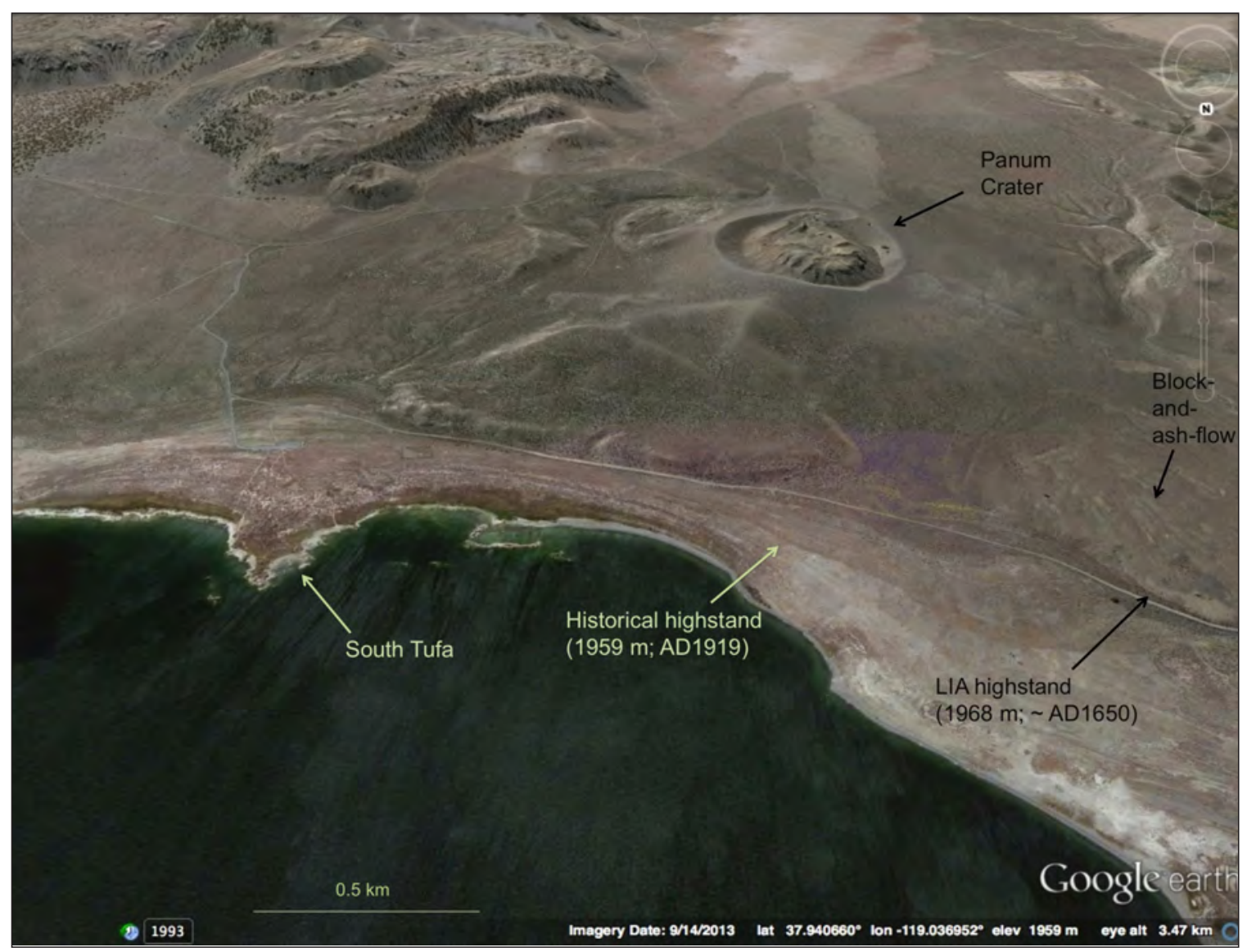

Figure 3.20. Google Earth ${ }^{\mathrm{TM}}$ image of the south shore of Mono Lake, looking south. Panum Crater formed about 600 yr BP, and is the northernmost of the Mono Craters chain (visible in the upper left). A block-and-ash flow extending north from the northwestern face of the crater displays the clearest expression of the Little Ice Age (LIA) high stand of the lake at $1967.7 \mathrm{~m}$, which dates to $296 \pm 10 \mathrm{cal}$ yr BP (Stine, 1990). The modern recession of the lake from the historical high stand in 1919 exposed the current shore face and the South Tufa towers, one of the iconic sights of the Mono Basin. 


\section{DAY 4. Pleistocene Mono Basin}

\section{Stop 4-1. Wilson Creek Type Section (313415 E $4210595 \mathrm{~N})$}

The Wilson Creek canyon was formed in the early part of the 20th century by water released from irrigation channels, and dramatically deepened in the mid-1950s, so that by 1964, Lajoie (1968) had unprecedented access to the stratigraphy we see today. The latest Pleistocene sediments of the Mono Lake basin were designated the Wilson Creek Formation by Lajoie (1968), because of their beautiful, extensive exposure here. Everywhere around the basin where channels or cliffs expose the sediments below about 2,000 m elevation, the Wilson Creek sediments are fine-grained deep-lake silts, interbedded with rhyolitic tephras presumed to be the eruption products of the Mono Craters. Higher in elevation, the deep-lake silts interfinger with beach and shoreline facies, and in the lower Wilson Creek canyon near Pole Line Road (about 2,050 m), with coarser sands and gravels (fig. 3.21).

The chronology of the Wilson Creek Formation has been unusually difficult to constrain, due to systematic difficulties with radiocarbon and ${ }^{40} \mathrm{Ar} /{ }^{39} \mathrm{Ar}$ dating (summarized by Zimmerman and others, 2011a). Recently, U-Th dating of allanites and zircons in the tephras has shown that Ash 7 is $26.8 \pm 2.1 \mathrm{ka}$, and Ash 19 is $61.7 \pm 1.9 \mathrm{ka}$, essentially in agreement with the paleomagnetic correlation of Zimmerman and others (2006). Ash 1, which is very near the top of the WCF, has generally been considered to be about
$12 \mathrm{ka}$ (Benson and others, 1998), but recent U-Th dating of clean calcites from tufa towers that are younger than Ash 1 demonstrate that it is older than $15.5 \mathrm{ka}$ (Wang and others, 2014).

The type-section stratigraphy begins at creek level with coarse fluvial gravels, overlain by deep-lake silts that are a two-component mixture of glacial rock flour and fine-grained authigenic carbonate (fig. 3.22A-C). The boundary between the gravels and silts is quite abrupt in the lower elevation parts of the channel, but includes wave-rippled sands at higher elevations. Two inclusions of note in the carbonate-flour mixture are the volcanic tephras and ice-rafted dropstones. The dropstones are best exposed in the lower part of the Wilson Creek stratigraphy, and are generally rounded cobbles of fine-grained black (likely metavolcanic) lithology, or classic Sierran granodiorite. Zimmerman and others (2011b) confirmed the casual observation that the dropstones are most concentrated below Marker Sequence C, and demonstrated that dropstones were carried and deposited by shore ice, rather than ice calved from the Sierran glaciers. The shore ice formed preferentially during periods of high lake level, probably due to freezing of a layer of freshwater floating on the denser alkaline lake water, as happens during particularly wet and cold winters. For example, during the unusually wet winter of 1982-1983, the western embayment of the lake froze out to Paoha Island, and the ice was thick enough to support skaters and skiers (Committee, 1983).

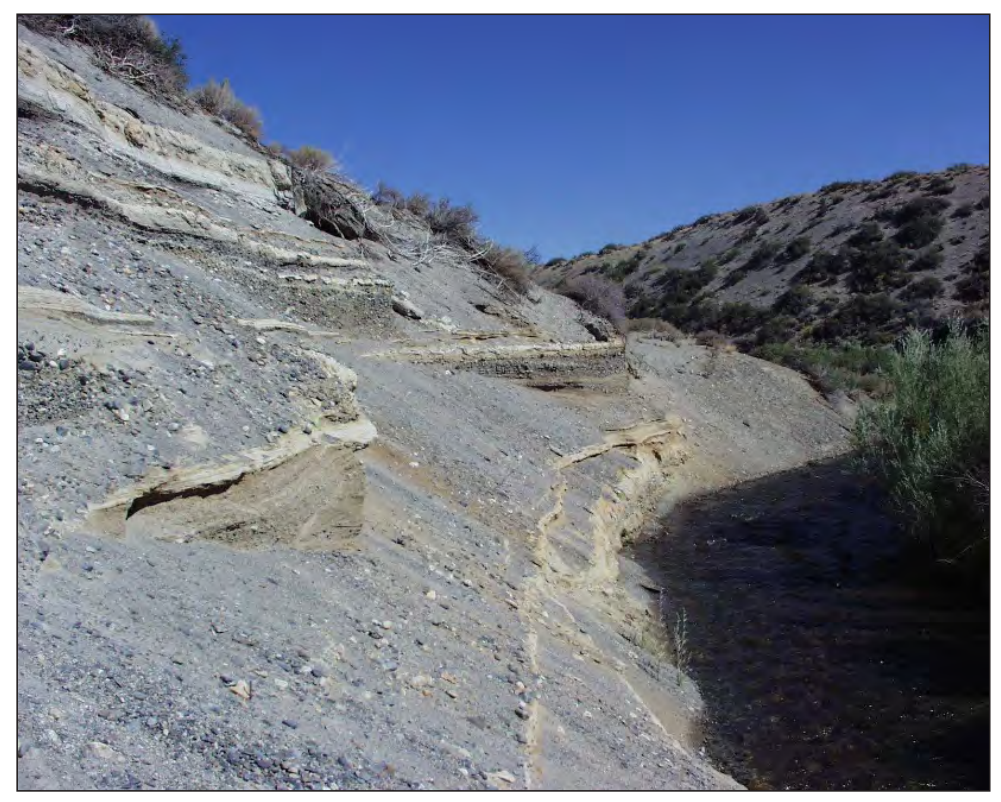

Figure 3.21. View looking south of fluvial, near-shore and deeper facies interfingering in the walls of upper Wilson Creek, just below Pole Line Road. (Photograph by S. Hemming, 2000.) 
A

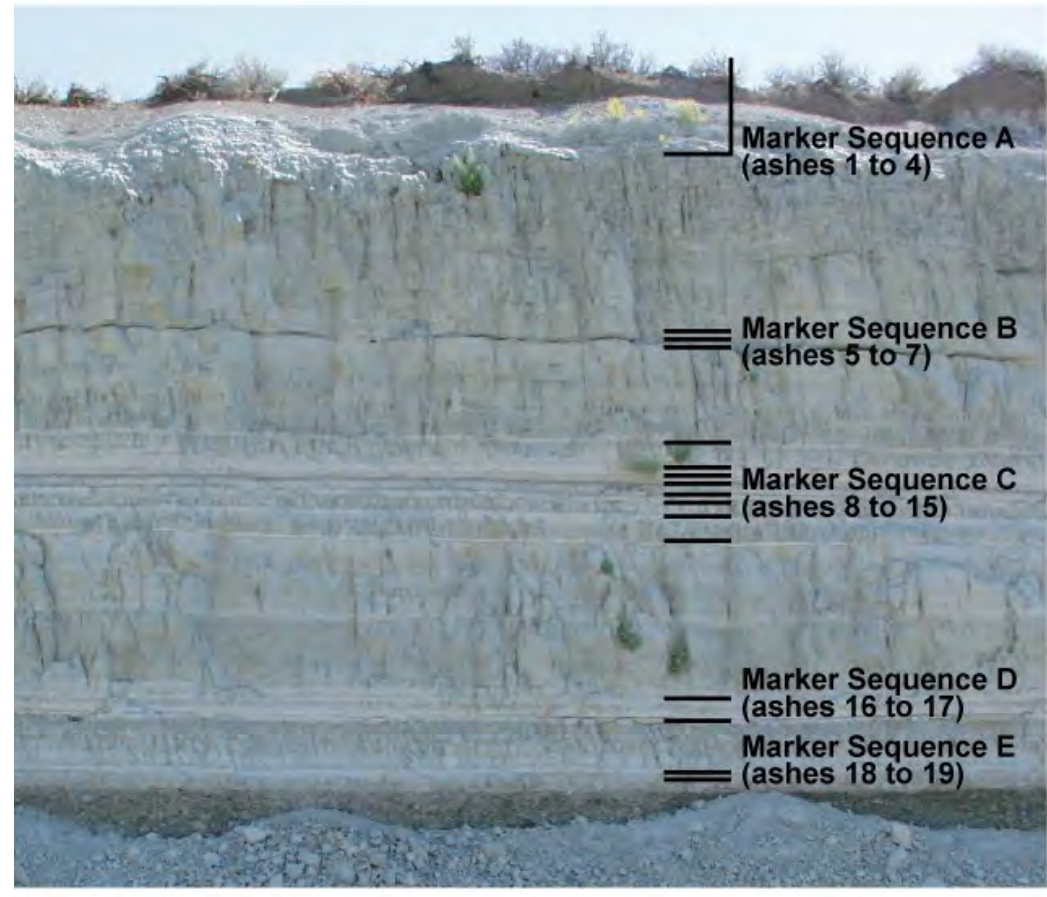

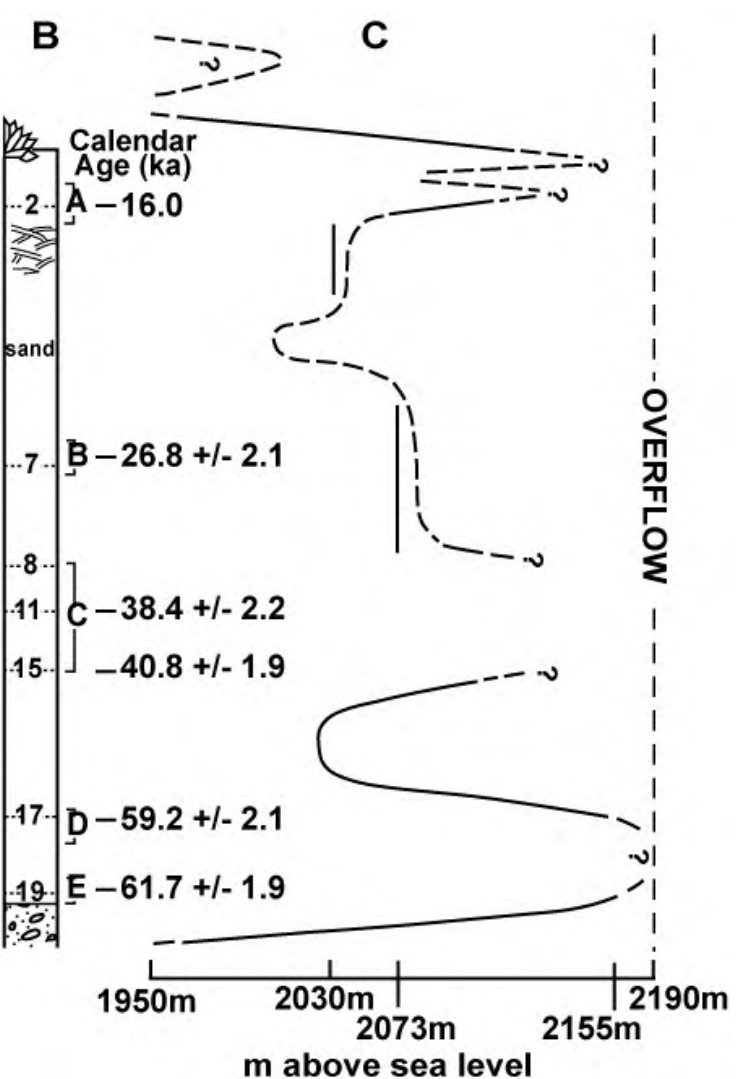

Figure 3.22. Wilson Creek Formation (WCF) stratigraphy, chronology and lake-level curve. A. Photograph of WCF type section showing stratigraphy from basal gravels to the bottom of basaltic Ash 2; marker sequence and ash appellations after Lajoie (1968). B. Cartoon of stratigraphy by Lajoie (1968) with U/Th allanite ages of Vazquez and Lidzbarski (2012), except Ash 2, unpublished age estimate of Wang and others (2012). C. Lake-level curve indicated by stratigraphic relationships of WCF exposures around the Mono basin, after Lajoie (1968). Although possible overflow was inferred by Lajoie (1968) during the earliest transgression, the interpretation of overflow is probably due to correlations based on poor age control.

The tephras are not evenly distributed in time, but occur in packages that Lajoie called Marker Sequences A (at the top, Ashes 1-4) through E (Ashes 18 and 19, just above the fluvial sequence). All but 1 of the 19 tephras are high-silica rhyolites; Ash 2 is basaltic, the product of the eruption of Black Point near the end of Wilson Creek time (early deglacial). The thickness of Ash 2 varies greatly from 6 to $7 \mathrm{~m}$ in parts of the northwestern exposures to a few centimeters in the southeastern exposures (Murtagh and White, 2013). A large part of the thickness of Ash 2 in the northwest is secondary deposition, presumably from ash-choked streams, which deposited classic sedimentary features such as climbing ripples. The distinctive packages of the rhyolitic ashes allowed Lajoie to correlate the stratigraphy almost everywhere around the basin, except in a few places where only two thin tephras are exposed. Recent work by Marcaida and Vazquez (2014) shows that, although the tephras may be indistinguishable in their glass major-element chemistry, the major-element chemistry of the titanomagnetite fraction can be used to distinguish nearly all tephras from one another. 


\section{Stop 4-2. Mill Creek Cut (312854 E 4210969 N)}

This exposure in Mill Creek (fig. 3.23) displays the upper part of the Wilson Creek Formation sequence, from the Holocene colluvium, down through Ash 4. Below Ash 4, there is dramatic evidence of the unconformity hinted at in the type section sands between Ashes 4 and 5. Here the complete sequence is preserved below Ash 8 and above Ash 4, but between them, the Marker Sequence B tephras (5-6-7) are missing, and in their place are alternating sands and silts, displaying considerable disruption.

This interval can be traced around the corner of the outcrop into the main creek wall, where the lower erosional surface cuts down to Ash 15. Sometime after Ash 5 was deposited (about $25 \mathrm{ka}$ ), the lake level declined to its lowest level in the last glacial period, cutting a channel in the Mill Creek stratigraphy. The channel is filled with sediments of the subsequent transgression, which was quite rapid and extensive, as evidenced by the occurrence of Ash 4 in finegrained lake sediment at Upper Wilson Creek, an elevation of at least 2,030 m. At Mill Creek, Ashes 4 and 3 are about $10 \mathrm{~cm}$ apart, and Ash 3 is about $5 \mathrm{~cm}$ below the base of Ash 2. Above Ash 2, Ash 1 occurs in carbonate-rich deep-lake sediments, and is capped by more carbonate-rich silt and Holocene colluvium, marking the regression from the highstand. The history of lake-level fluctuations between the end of the Wilson Creek Formation deposition and the 4,000-year highstand at 1,980 masl is thus far poorly known.

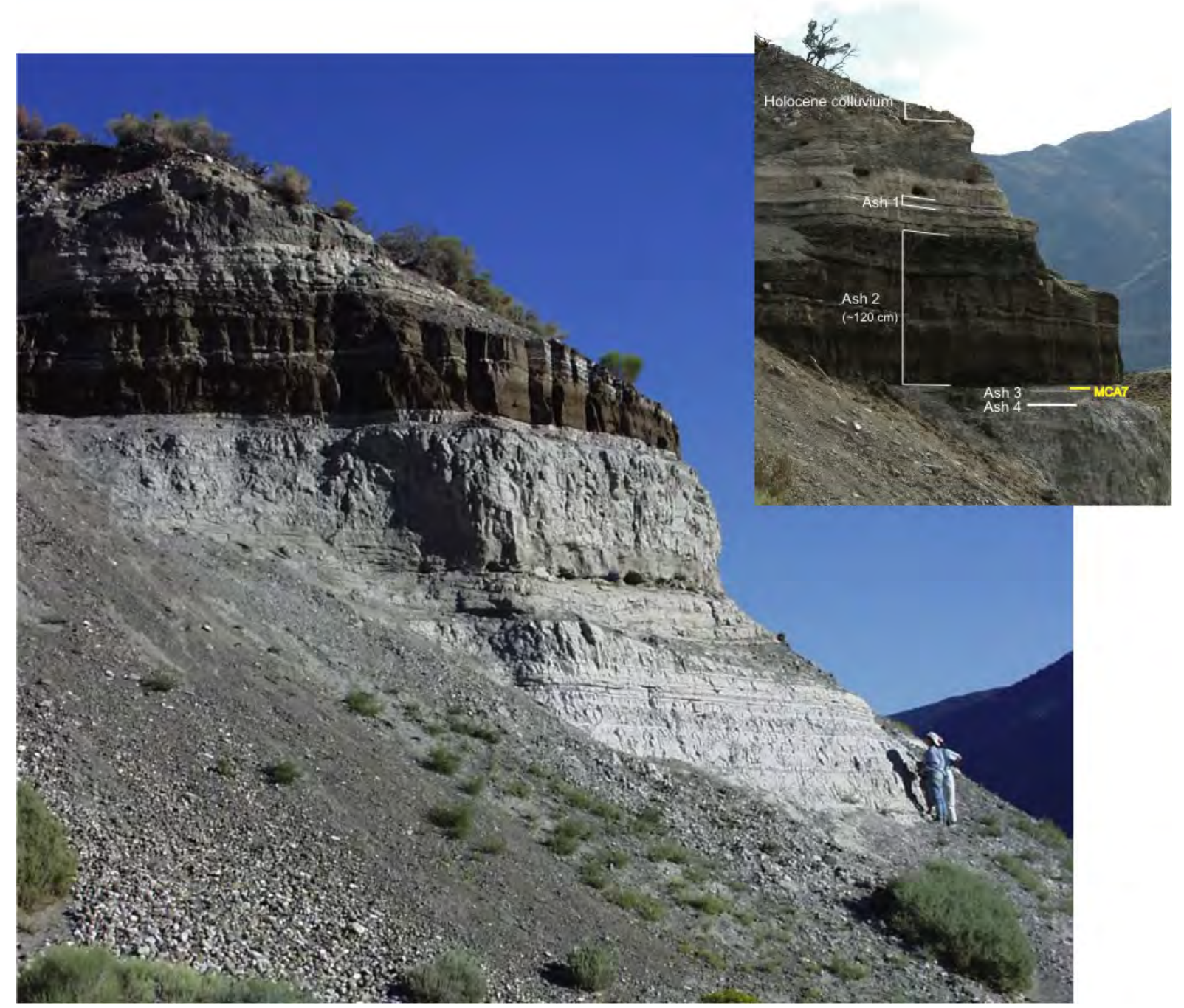

Figure 3.23. Mill Creek outcrop, showing interval of regression and transgression between Ashes 4 and 5 . Ashes 3 and 4 are about $10 \mathrm{~cm}$ apart, about $5 \mathrm{~cm}$ below basaltic Ash 2. Much of the thickness of Ash 2 here and elsewhere in the northwestern part of the basin is erosion of eruption material deposited on land and in stream channels (Photograph by S. Hemming, 2000; inset photographs after Zimmerman and others, 2012). 


\section{Stop 4-3. Lundy Canyon (308788 E 4211506 N)}

Lundy Canyon is the northernmost of the glacial canyons in the Mono basin, and shows several generations of moraines. Rood and others (2011a) used ${ }^{10}$ Be dating to show that the prominent moraines extending out from the glacial valley correspond to the middle of the last glacial period, centering around $17.9 \pm 1.6 \mathrm{ka}$. Unlike the other canyons, however, the Lundy moraines extend out across the Sierran frontal fault and onto the old lake plain, and have therefore been more extensively down-dropped. Rood and others (2011b) measured $22 \mathrm{~m}$ of offset on the Tioga moraines, and calculated an average slip rate of $>1 \mathrm{~mm} / \mathrm{yr}$ on that section of the fault, the highest documented in the region. Older Sherwin lateral moraines can be seen just above and outboard of the Tioga moraines, but there are relatively few recessionals nested inside, unlike several of the other canyons. The natural drainage of Lundy canyon is down Mill Creek, but in 1911 Lundy Lake was dammed to generate hydropower, and the flow of Mill Creek since has been diverted to Wilson Creek. The loss of natural flow conditions on the diverted streams in the basin and the resulting effects on the riparian ecosystems have been one of the major areas of restoration effort over the last 20 years. Great strides have been made in Rush Creek, and Mill Creek restoration was begun in the summer 2014.

\section{Stop 4-4. Bloody Canyon (311644 E 4195878 N)}

Bloody Canyon is one of the classic moraine sequences of the American West, because of the fact that the Tahoe glacier broke out of the earlier glacial path, overriding the left lateral moraine of the previous glaciation and thus preserving that earlier moraine set, the Sawmill Canyon moraines (fig. 3.24). The moraines were dated with ${ }^{36} \mathrm{Cl}$ exposure dating by Phillips and others (1990, 1996) but those dates are whole-rock analyses that are now considered unreliable. Schaefer and others (2009) applied ${ }^{10}$ Be dating to the Bloody Canyon sequence, and found glacial maximum and early recessional moraines of 17 and $19 \mathrm{ka}$. Attempts to date the older Sawmill Canyon moraines encountered one of the fundamental limitations of the cosmogenic surface-exposure dating technique - the impact that weathering has on exposure dating. The Sawmill Canyon moraines may be correlative with MIS 6, but this remains conjecture until additional dating is performed.

We will again spend the night at June Lake.

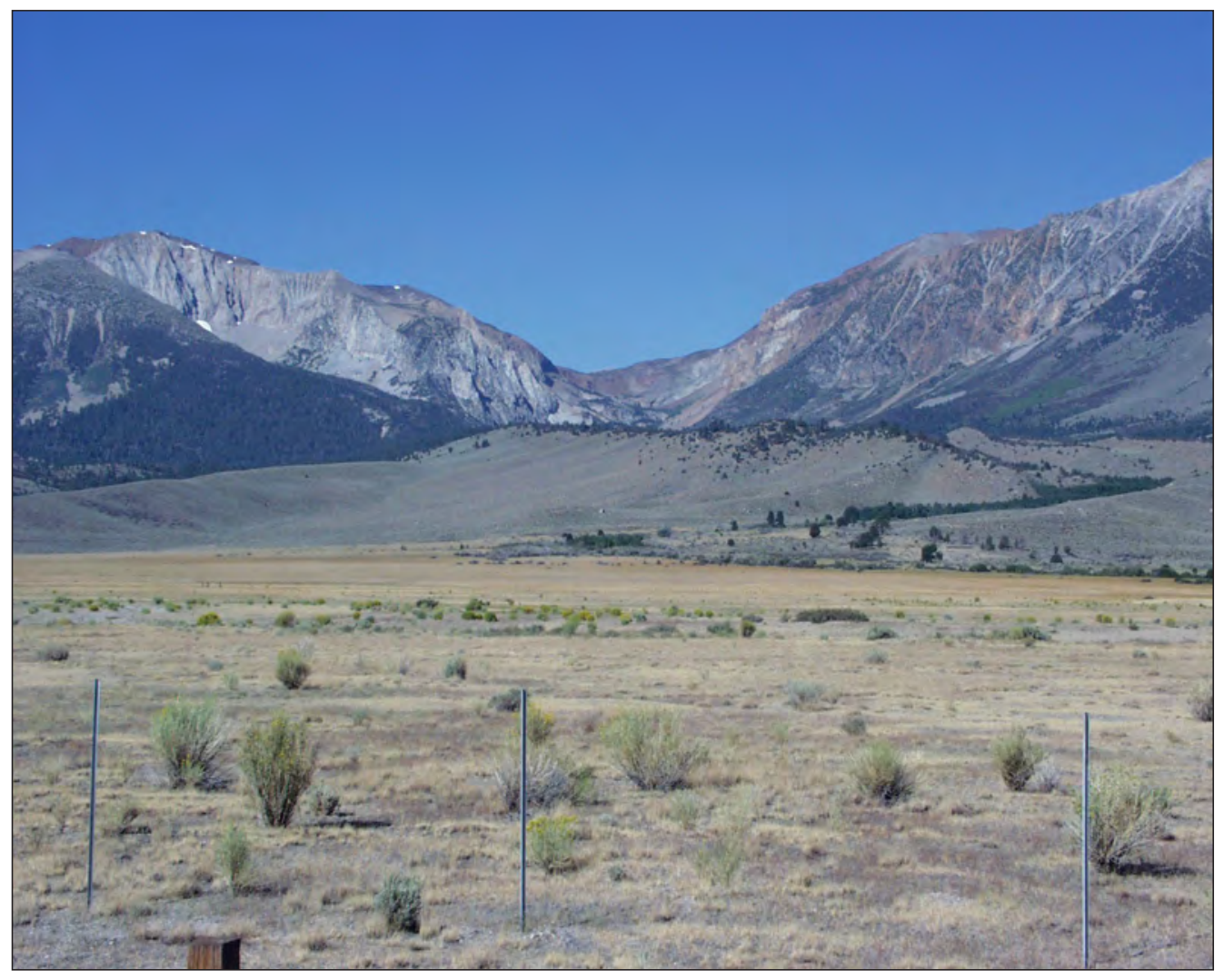

Figure 3.24. Moraines of Bloody Canyon, looking west. The Tioga and Tahoe moraines extend center-to-left, and curve to the right at the end; the Sawmill Canyon moraines underlie those and therefore must be older, but are too weathered to apply to simple exposure dating. (Photograph by S. Hemming, 2000.) 


\section{DAY 5. Bodie State Historic Park and Washoe Lake}

\section{Stop 5-1. Bodie State Historic Park (323573 E 4231439 N)}

Bodie is a former gold and silver mining town that existed during the California gold rush (fig. 3.25). The town is named for Waterman S. Body (William Bodey), who had discovered small amounts of gold in hills north of Mono Lake. In 1875, a mine cave-in revealed a much more robust amount of gold and silver to be mined. This led to the mine being purchased by the Standard Company in 1877. People then flocked to Bodie and the town quickly became a boomtown. From 1877 to 1888 , Bodie was a town with more than 10,000 residents and the mines here produced more than \$35 million in gold and silver.
Once the gold was mined out, people left the buildings, tools, and supplies as they were.

Only a small part of the town now survives, preserved in a state of "arrested decay" by the California Park System. Bodie was designated as a National Historic Site and a State Historic Park in 1962. Today, there are 170 wooden buildings remaining that can be looked into and explored. Bodie is at an elevation of 2,552.7 masl (8,375 ft). Buildings of interest are the church, schoolhouse, barbershop, and saloon, where bottles, desks, and other relics remain. Most of the information for this stop was modified from http://www.parks. ca.gov/?page_id=509.

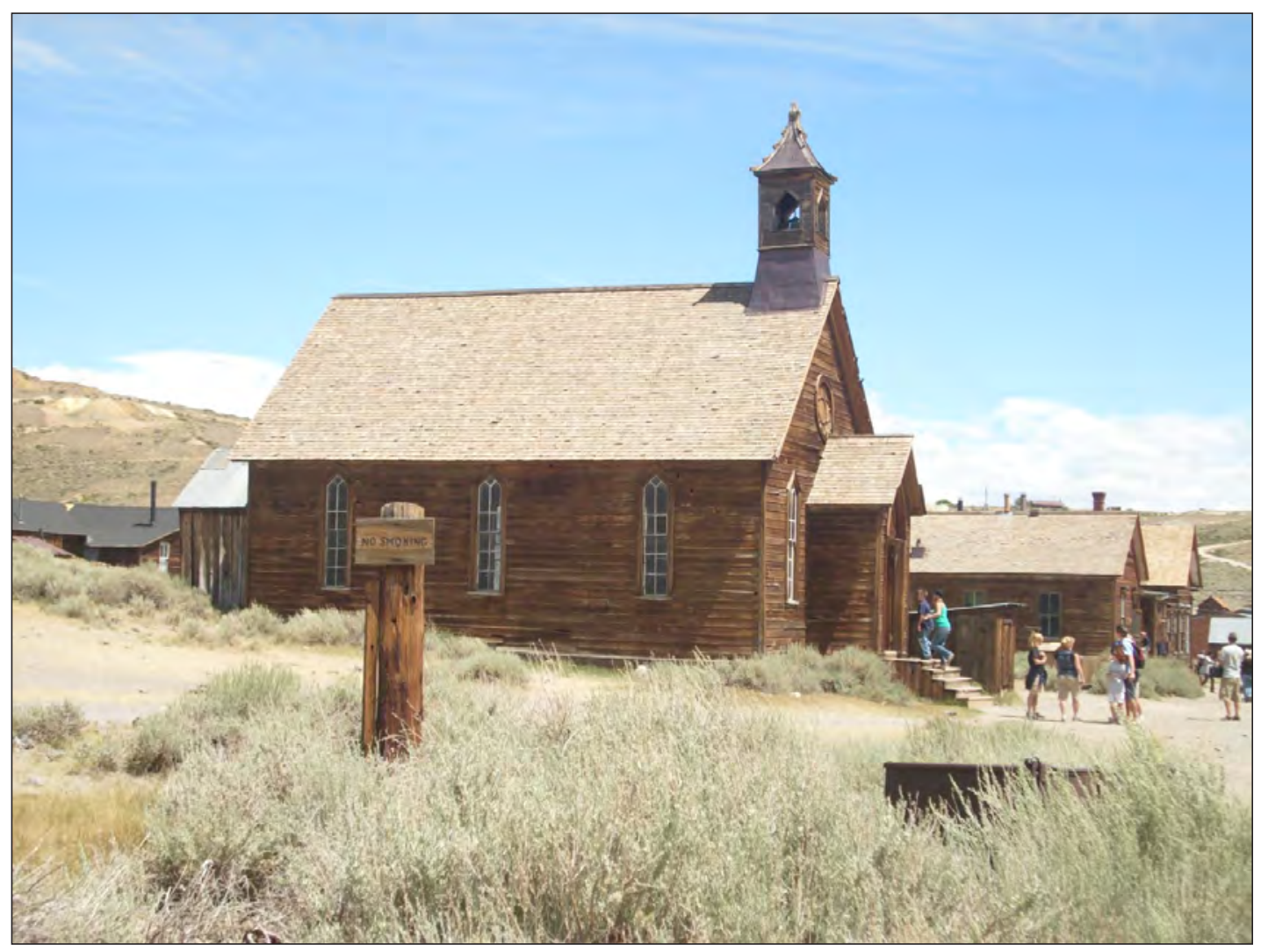

Figure 3.25. Church at Bodie, California. (Photograph by Nicholas G. Rosen, used with permission.) 


\section{Stop 5-2. Washoe Lake (259218 E 4351076 N)}

Washoe Lake is located between Carson City and Reno, Nevada, in the high-Sierran semiarid desert environment near the present boundary between the pinyon pine/mountain mahogany and the sagebrush ecotomes. The lake is relatively fresh; total dissolved solids in September 2013 (the driest part of the year) were 1,203 mg/L (data are from Randy Pahl, Nevada Department of Environmental Protection, written commun., 2013). The lake has a pH of about 8.6 and the chemistry is dominated by $\mathrm{Ca}$ and $\mathrm{HCO}_{3}$, although few analyses of the water chemistry are available. In late spring 1993, the lake was approximately $31 \mathrm{~km}^{2}$ in area and averaged 3-4 $\mathrm{m}$ in depth. During the Pleistocene, the water depth was about 13-17 m, and the lake occupied a much more extensive area, as evidenced by strand lines above the lake margins. Geologic studies of the basin sides indicated that lacustrine sediments have been deposited for at least the last $2.5 \mathrm{Ma}$ (Karlin and others, 1996).

Very little scientific work has been done at Washoe Lake. In late June 1991, however, the lake desiccated due to below average snowpack for the previous 4 years, which caused low runoff from the Sierras. This was the second time the lake had desiccated in recorded history, with the previous time in 1933-34. This offered an opportunity to obtain long continuous cores from a quasi-permanent lake in a climatically sensitive region (Karlin and others, 1996).

To our knowledge, the study by Karlin and others (1996) is the only work that has been done on the limnogeology of Washoe Lake. The following description of the limnogeology done on the lake comes from this study.
Washoe Lake is in an asymmetric fault-bounded half graben surrounded by the Carson and Virginia Ranges to the west and east, respectively, the Truckee Meadows to the north, and the Carson River basin to the south (fig. 3.26). Gravity modeling of the basin indicates that the lake is underlain by sediment thicknesses of almost $600 \mathrm{~m}$, with maximum accumulations at the western end. A major change in sedimentary facies from coarse alluvial sands in the west to fine-grained lacustrine sediments in the east coincides with a deep basement offset shown by magnetic anomalies. The deepest part of the current lake is east of the zone of thickest sediment accumulation. These relations indicate that ancient and modern sedimentation patterns in the lake are tectonically controlled.

Karlin and others (1996) cored two sites on the lake to $25 \mathrm{~m}$ depth, with about 85 percent recovery. Two other sites yielded about $13 \mathrm{~m}$ of section until penetration was stopped due to fluidized sands. The drill holes were geophysically logged to allow the sediments to be reoriented in situ.

Near the depositional center of the lake basin, the top $12 \mathrm{~m}$ of sediment consists of alternating intervals of lake sediments, peaty-bog deposits, and soils. The lower part of the drill core contains mostly lake sediments, probably deposited within the last 60,000 years, although age control is not presented for this part of the core. The lake sediments are characterized by elevated $\mathrm{CaCO}_{3}$ concentrations, low susceptibilities, and relatively low abundances of terrigenous elements, such as $\mathrm{Al}, \mathrm{K}$, and $\mathrm{Na}$. The carbonate minerals are calcite and aragonite that were authigenically precipitated during alkaline and probably saline lake stages. The soils in the cores show an inverse relation of $\mathrm{CaCO}_{3}$ to terrigenous elemental abundances. Peaty intervals show relatively high

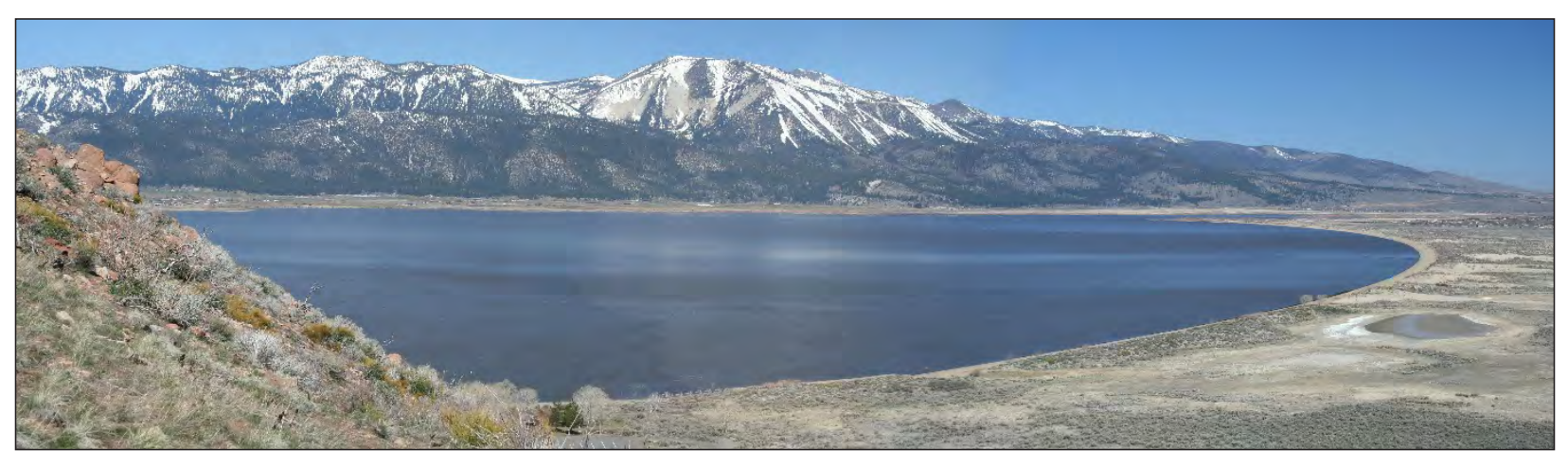

Figure 3.26. Washoe Lake in April 2008 looking west to the Carson Range. Low (10 m or less) sand dunes can be seen in the right of the photograph. (Composite photograph by Michael R. Rosen, U.S. Geological Survey, April 16, 2008.) 
organic carbon, low $\mathrm{CaCO}_{3}$, and intermediate aluminum oxide concentrations. Magnetic-susceptibility maxima mostly indicated intermittent sand layers that were deposited in different environments. Sands present in different depth intervals were interpreted to be derived from turbidites and subaerial sheet-flow deposits that formed during lake stages. As might be expected, discontinuous channelized fluvial sands were deposited during the peaty-bog stages, and deflationary lag deposits formed during arid-soil stages. The sediment record shows that climate varied substantially during the Holocene. The top $3 \mathrm{~m}$ of sediment contained several silt/clay layers, some of which contained clam zones, peaty zones, and soils, indicating that the lake has at least partially desiccated several times during the Holocene.

In the last 2,600 years, the climate in the study area was relatively wet, and Washoe Lake has been perennial, except for three brief desiccation episodes. Earlier in the Holocene, the climate was generally drier and more variable, allowing soil development and marshy peat horizons. The results from Washoe Lake are consistent with a warm, arid, period from about 6,000 to 4,000 years ago that dropped the level of Lake Tahoe 10-20 m (Lindström, 1990).

\section{References Cited}

Adams, K.D., 2003, Age and paleoclimatic significance of late Holocene lakes in the Carson Sink, Nevada, USA: Quaternary Research, v. 60, p. 294-306.

Adams, K.D., 2007, Late Holocene sedimentary environments and lake-level fluctuations at Walker Lake, Nevada, USA: Geological Society of America Bulletin, v. 119, p. 126-139.

Adams, K.D., 2008, Lake-level fluctuations in the western Great Basin during the Medieval Climate Anomaly: episodes of both drier and wetter periods than modern: Geological Society of America Abstracts with Programs, v. 40, p. 227.

Adams, K.D., 2010, Lake levels and sedimentary environments during deposition of the Trego Hot Springs and Wono tephras in the Lake Lahontan basin, Nevada, USA: Quaternary Research, v. 73, p. 118-129.

Adams, K.D., 2013, Quantifying magnitudes and rates of climate-induced hydrologic change: Geological Society of America Abstracts with Programs, v. 45, p. 711.

Adams, K.D., and Wesnousky, S.G., 1999, The Lake Lahontan highstand: Age, surficial characteristics, soil development, and regional shoreline correlation: Geomorphology, v. 30, p. 357-392.
Adams, K.D., Bacon, S.N., Lancaster, N., Rhodes, E.J., and Negrini, R.M., 2014, How wet can it get? Defining future climate extremes based on late Holocene lake-level records: Geological Society of America Abstracts with Programs, v. 46, p. 745.

Benson, L.V., Lund, S.P., Burdett, J.W., Kashgarian, M., Rose, T.P., Smoot, J.P., and Schwartz, M., 1998, Correlation of Late-Pleistocene lake-level oscillations in Mono Lake, California, with North Atlantic climate events: Quaternary Research, v. 49, p. 1-10.

Benson, L.V., and Thompson, R.S., 1987, The physical record of lakes in the Great Basin, in Ruddiman, W.F., and Wright, H.E., Jr., eds., North America and adjacent oceans during the last deglaciation, Boulder, Colorado, Geological Society of America, p. 241-260.

Birkeland, P.W., 1968, Mean velocities and boulder transport during Tahoe-age floods of the Truckee River, CaliforniaNevada: Geological Society of America Bulletin, v. 79, p. 137-142.

Bischoff, J.L., Stine, S., Rosenbauer, R.J., Fitzpatrick, J.A., and Stafford, T.W., Jr., 1993, Ikaite precipitation by mixing of shoreline springs and lake water, Mono Lake, California, USA: Geochemica et Cosmochemica Acta, v. 57, p. 3855-3865.

Breeze, C.R., Jr., 1968, A general limnological study of Big Soda Lake: Reno, University of Nevada, M.S. thesis, 83 p.

Bursik, M., and Sieh, K., 2013, Digital database of the Holocene tephras of the Mono-Inyo Craters, California: U.S. Geological Survey Data Series 758.

Cloern, J.E., Cole, B.E., and Oremland, R.E., 1983, Seasonal changes in the chemistry and biology of a meromictic lake (Big Soda Lake, Nevada, U.S.A.): Hydrobiologia, v. 105, p. 195-206.

Cloud, P., and Lajoie, K.R., 1980, Calcite-impregnated defluidization structures in littoral sands of Mono Lake, California: Science, v. 210, p. 1009-1012.

Committee, M.L., 1983, The Mono Naturalist: The Mono Lake Newsletter, p. 9-10.

Cook, E.R., Seager, R., Heim, R.R.J., Vose, R.S., Herweijer, C., and Woodhouse, C., 2010, Megadroughts in North America: placing IPCC projections of hydroclimatic change in a long-term palaeoclimate context: Journal of Quaternary Science, v. 25, p. 48-61.

Cook, E.R., Woodhouse, C., Eakin, C.M., Meko, D.M., and Stahle, D.W., 2004, Long-term aridity changes in the western United States: Science, v. 306, p. 1015-1018. 
Council, T.C., and Bennett, P.C., 1993, Geochemistry of ikaite formation at Mono Lake, California: Implications for the origin of tufa mounds: Geology, v. 21, no. 11, p. 971.

Dana, E.S., 1884, A crystallographic study of the thinolite of Lake Lahontan: U.S. Geological Survey Bulletin, v. 12, p. 429-486.

Davis, J.O., 1978, Quaternary tephrochronology of the Lake Lahontan area, Nevada and California: University of Nevada, Nevada Archeological Survey Research Paper 7, $137 \mathrm{p}$.

Davis, J.O., 1985, Sediments and geologic setting of Hidden Cave, in Thomas, D.H., ed., The archaeology of Hidden Cave: New York, American Museum of Natural History Anthropological Papers, v. 61, p. 80-103.

Deines, P., Langmuir, D., and Harmon, R.S., 1974, Stable carbon isotope ratios and the existence of a gas phase in the evolution of carbonate ground waters: Geochimica et Cosmochimica Acta, v. 38, p. 1147-1164.

Dunn, J. R., 1953, The origin of the deposits of tufa in Mono Lake: Journal of Sedimentary Petrology, v. 23, no. 1, p. 18-23.

Gilbert, G.K., 1890, Lake Bonneville. U.S. Geological Survey Monograph 1, 438 p.

Gillespie, A.R., and Clark, D.H., 2011, Glaciations of the Sierra Nevada, California, USA, in Ehlers, J., Gibbard, P.L., and Hughes, P.D., eds., Quaternary Glaciations-Extent and chronology, a closer look, vol. 15: Developments in Quaternary Science: Amsterdam, Elsevier, p. 447-462.

Herbst, D.B., 1990, Distribution and abundance of the alkali fly (Ephydra hians) at Mono Lake, California (USA) in relation to physical habitat: Hydrobiologia, v. 197, p. 193205.

Herbst, D.B., and Bradley, T. J., 1989, A Malpighian tubule lime gland in an insect inhabiting alkaline salt lakes: Journal of Experimental Biology, v. 145, p. 63-78.

Hildreth, W., 2004, Volcanological perspectives on Long Valley, Mammoth Mountain, and Mono Craters: several contiguous but discrete systems: Journal of Volcanology and Geothermal Research, v. 136, p. 169-198.

Hutchinson, G.E., 1937, A contribution to the limnology of arid regions, primarily founded on observations made in the Lahontan Basin: Connecticut Academy of Arts and Sciences Transactions, v. 33, p. 47-132.

Jones, B.F., 1966, Geochemical evolution of closed basin waters in the western Great basin: Ohio Geological Society Symposium on Salt, 2nd, 1, p. 181-200.
Karlin, R.E., Trexler, J.T., and Petersen R., 1996, Initial results from paleoclimatic and geophysical Studies of Washoe Lake, Nevada, in Benson, L.V., ed., Proceedings of the workshop "Ongoing paleoclimatic studies in the Northern Great Basin,” Reno, Nevada, May 1993: U.S. Geological Survey Circular 1119, p. 37-38.

Kelleher, P.C., and Cameron, K.L., 1990, The geochemistry of the Mono Craters-Mono Lake islands volcanic complex, eastern California: Journal of Geophysical Research, v. 95, no. B11, p. 17643-17659.

Kharaka, Y.K., Robinson, S.W., Law, L.M., and Carothers, W.W., 1984, Hydrogeochemistry of Big Soda Lake, Nevada: An alkaline meromictic desert lake: Geochimica et Cosmochimica Acta, v. 48, p. 823-835.

King, C., 1877, United States Geological Exploration of the 40th parallel: U.S. Army Engineer Department Professional Paper 18, 7 volumes.

Kulp, T.R., Hoeft, S.E., Asao, M., Madigan, M.T., Hollibaugh, J.T., Fisher, J.C., Stolz, J.F., Culbertson, C.W., Miller, L.G., and Oremland, R.S., 2008, Arsenic(III) fuels anoxygenic photosynthesis in hot spring biofilms from Mono Lake, California: Science, v. 321, p. 967-970.

Lajoie, K.R., 1968, Quaternary stratigraphy and geologic history of Mono Basin, Eastern California: University of California, Ph.D. thesis, 271 p.

Lindström, S., 1990, Tree stumps as indicators of midHolocene aridity in the Lake Tahoe Basin: Journal of California and Great Basin Anthropology, v. 12, no. 2, p. 146-157.

Marcaida, M., Mangan, M.T., Vazquez, J.A., Bursik, M., and Lidzbarski, M.I., 2014, Geochemical fingerprinting of Wilson Creek formation tephra layers (Mono Basin, California) using titanomagnetite compositions: Journal of Volcanology and Geothermal Research, v. 273, p. 1-14.

Marcaida, M., and Vazquez, J.A., 2014, ${ }^{238} \mathrm{U}^{230} \mathrm{Th}$ crystallization ages for the oldest domes of the Mono Craters, eastern California: AGU Fall Meeting: San Francisco, Abstract V33A-4825, https://agu.confex.com/ agu/fm14/meetingapp.cgi\#Paper/14288.

Mason, D.T., 1967, Limnology of Mono Lake, California: University of California Publications in Zoology, University of California Press.

Meyers, P.A., Tenzer G.E., Lebo, M.E,, and Reuter, J.E., 1998, Sedimentary record of sources and accumulation of organic matter in Pyramid Lake, Nevada, over the past 1,000 years: Limnology and Oceanography, v. 43, p. 160-169. 
Mifflin, M.D., 1968, Delineation of ground-water flow systems in Nevada: Technical Report Series H-W, University of Nevada, Desert Research Institute, no. 4, 54 p.

Morrison, R.B., 1964, Lake Lahontan: Geology of the southern Carson Desert: U.S. Geological Survey Professional Paper 401, 156 p.

Morrison, R.B., 1991, Quaternary stratigraphic, hydrologic, and climatic history of the Great Basin, with emphasis on Lake Lahontan, Bonneville, and Tecopa, in Morrison, R.B., ed., Quaternary nonglacial geology; conterminous U.S.: Boulder, Colorado: United States, Geological Society of America, p. 283-320.

Murtagh, R.M., and White, J.D.L., 2013, Pyroclast characteristics of a subaqueous to emergent Surtseyan eruption, Black Point volcano, California: Journal of Volcanology and Geothermal Research, v. 267, p. 75-91.

O’Neil, J.R., Clayton, R.N., and Mayeda, T.K., 1969, Oxygen isotope fractionation in divalent metal carbonates: Journal of Chemistry and Physics, v. 51, p. 5547-5558.

Oremland, R.S., Miller, L.G., and Whiticar, M.J., 1987, Sources and flux of natural gases from Mono Lake, California: Geochemica et Cosmochemica Acta, v. 51, p. 2915-2929.

Oremland, R.S., Cloern, J.E., Sofer, Z., Smith, R.L., Culbertson, C.W., Zehr, J., Miller, L., Cole, B., Harvey, R., Iversen, N., Klug, M., Des Marais, D.J., and Rau, G., 1988, Microbial and biogeochemical processes in Big Soda Lake, Nevada, in Fleet, A.J., et al., eds., Lacustrine petroleum source rocks: Geological Society [London] Special Publication 40, p. 59-75.

Phillips, F.M., Zreda, M.G., Benson, L.V., Plummer, M.A., Elmore, D., and Sharma, P., 1996, Chronology for Fluctuations in Late Pleistocene Sierra Nevada Glaciers and Lakes: Science, v. 274, no. 5288, p. 749-751.

Phillips, F.M., Zreda, M. G., Smith, S. S., Elmore, D., Kubik, P. W., and Sharma, P., 1990, Cosmogenic Chlorine-36 Chronology for Glacial Deposits at Bloody Canyon, Eastern Sierra Nevada: Science, v. 248, p. 1529-1532.

Reheis, M.C., Adams, K.D., Oviatt, C.G., and Bacon, S.N., 2014, Pluvial lakes in the Great Basin of the western United States: A view from the outcrop: Quaternary Science Reviews, v. 97, p. 33-57.

Rhode, D., Adams, K.D., and Elston, R.G., 2000, Geoarchaeology and Holocene landscape history of the Carson Desert, western Nevada, in Lageson, D.R., Peters, S.G., and Lahren, M.M., eds., Great Basin and Sierra Nevada: Geological Society of America Field Guide 2, Boulder, p. 45-74.
Reidy, L.M., 2013, Lake sediments as evidence of natural and human-induced environmental change from California and Nevada: University of California, Ph.D. dissertation, 99 p.

Rood, D.H., Burbank, D.W., and Finkel, R.C., 2011a, Chronology of glaciations in the Sierra Nevada, California, from ${ }^{10} \mathrm{Be}$ surface exposure dating: Quaternary Science Reviews, v. 30, no. 5-6, p. 646-661.

Rood, D.H., Burbank, D.W., and Finkel, R.C., 2011b, Spatiotemporal patterns of fault slip rates across the Central Sierra Nevada frontal fault zone: Earth and Planetary Science Letters, v. 301, p. 457-468.

Rosen, M.R., 2015, The influence of hydrology on lacustrine sediment contaminant records, in Blais, J.M., Rosen M.R., Smol, J.P. (eds.) Environmental contaminants: Using natural archives to track sources and long-term trends of pollution: Springer, Dordrecht, p. 5-34.

Rosen, M.R., Arehart, G.B., and Lico, M.S., 2004, Exceptionally fast growth of $<100$-year-old tufa, Big Soda Lake, Nevada: Implications for using tufa as a paleoclimate proxy: Geology, v. 32, p. 409-412.

Rush, F.E., 1972, Hydrologic reconnaissance of Big and Little Soda Lakes, Churchill County, Nevada: Carson City, Nevada Department of Conservation and Natural Resources, Division of Water Resources, 1 p.

Russell, I.C., 1885, Geological history of Lake Lahontan, a Quaternary lake of northwestern Nevada: U.S. Geological Survey, Washington, D.C., 288 p.

Russell, I.C., 1889, Quaternary history of the Mono Valley, California, Eighth Annual Report of the United States Geological Survey: Lee Vining, CA, Artemisia Press, 267-394 p.

Schaefer, J. M., Denton, G.H., Kaplan, M., Putnam, A., Finkel, R.C., Barrell, D.J., Andersen, B.G., Schwartz, R., Mackintosh, A., Chinn, T., and Schluchter, C., 2009, High-frequency Holocene glacier fluctuations in New Zealand differ from the northern signature: Science, v. 324, no. 5927, p. 622-625.

Scholl, D.W., and Taft, W.H., 1964, Algae, contributors to the formation of calcareous tufa, Mono Lake, California: Journal of Sedimentary Petrology, v. 34, no. 2, p. 309-319.

Shearman, D.J., McGugan, A., Stein, C., and Smith, A.J., 1989, Ikaite, $\mathrm{CaCO}_{3} \cdot 6 \mathrm{H}_{2} \mathrm{O}$, precursor of the thinolites in the Quaternary tufas and tufa mounds of the Lahontan and Mono Lake Basins, western United States: GSA Bulletin, v. 101, p. 913-917. 
Sieh, K., and Bursik, M., 1986, Most recent eruption of the Mono Craters, eastern central California: Journal of Geophysical Research, v. 91, no. B12, p. 12,539-12,571.

Smith, G.I., and Street-Perrott, F.A., 1983, Pluvial lakes of the Western United States, in Porter, S.C., ed., The late Pleistocene: Minneapolis, Minnesota, United States: University of Minnesota Press, p. 190-212.

Souza-Egipsy, V., Wierzchos, J., Ascaso, C., and Nealson, K.H., 2005, Mg-silica precipitation in fossilization mechanisms of sand tufa endolithic microbial community, Mono Lake (California): Chemical Geology, v. 217, no. 1-2, p. 77-87.

Stine, S., 1987, Mono Lake: The past 4,000 years: University of California, 615 p.

Stine, S., 1990, Late Holocene fluctuations of Mono Lake, eastern California: Palaeogeography, Palaeoclimatology, Palaeoecology, v. 78, p. 333-381.

Stine, S., 1991, Geomorphic, geographic, and hydrographic basis for resolving the Mono Lake controversy:

Environmental Geology and Water Sciences, v. 17, no. 2, p. 67-83.

Stine, S., 1994, Extreme and persistent drought in California and Patagonia during mediaeval time: Nature, v. 369, p. 546-549.

Vazquez, J.A., Calvert, A.T., Marcaida, M., Mangan, M., Lidzbarski, M.I., and Stelten, M.E., 2013, Resolving the early chronology of Mono Craters volcanism with combined ${ }^{238} \mathrm{U}^{2}{ }^{230} \mathrm{Th}$ and ${ }^{40} \mathrm{Ar}-{ }^{39} \mathrm{Ar}$ dating, in American Geophysical Union Fall Meeting, San Francisco.

Vazquez, J.A., and Lidzbarski, M.I., 2012, High-resolution tephrochronology of the Wilson Creek Formation (Mono Lake, California) and Laschamp event using ${ }^{238} \mathrm{U}-{ }^{230} \mathrm{Th}$ SIMS dating of accessory mineral rims: Earth and Planetary Science Letters, v. 357-358, p. 54-67.
Wang, X., Ali, G., Hemming, S., Zimmerman, S., Stine, S., and Hemming, G., 2014, Lake level changes in the Mono basin during the last deglacial period: American Geophysical Union Fall Meeting: San Francisco, Abs. no. 1157.

Wesnousky, S.G., 2005, Active faulting in the Walker Lane: Tectonics, v. 24, p. TC3009, doi:10.1029/2004TC001645.

Wolfe-Simon, F., Blum, J.S., Kulp, T.R., Gordon, G.W., Hoeft, S.E., Pett-Ridge, J., Stolz,J.F., Webb, S.M., Weber, P.K., Davies, P.C.W., Anbar, A.D., and Oremland, R.S., 2011, A bacterium that can grow by using arsenic instead of phosphorus: Science, v. 332, p. $1163-1166$.

Zimmerman, S.H., 2006, Chronology and Paleoclimate Records of the Late Pleistocene Wilson Creek Formation at Mono Lake, California: Ph.D. Dissertation: Columbia University, 203 p.

Zimmerman, S.H., Hemming, S.R., Hemming, N.G., Tomascak, P.B., and Pearl, C., 2011a, High-resolution chemostratigraphic record of late Pleistocene lake-level variability, Mono Lake, California: Geological Society of America Bulletin, v. 123, no. 11, p. 2320-2334.

Zimmerman, S.H., Pearl, C., Hemming, S.R., Tamulonis, K., Hemming, N.G., and Searle, S.Y., 2011b, Freshwater control of ice-rafted debris in the last glacial period at Mono Lake, California, USA: Quaternary Research, v. 76, p. 264-271.

Zimmerman, S.R.H., Steponaitis, E., Hemming, S.R., and Zermeño, P., 2012, Potential for accurate and precise radiocarbon ages in deglacial-age lacustrine carbonates: Quaternary Geochronology, v. 13, p. 81-91. 


\section{Trip 4.-Subalpine Lakes in An Active Volcanogenic Setting (Lassen Volcanic National Park, California)}

\author{
By Kerry L. Howard' and Paula J. Noble ${ }^{1}$
}

\section{Introduction}

This field trip provides an overview of the geologic setting and limnology of Lassen Volcanic National Park (LAVO) lakes through a transect of the park, and then focuses on two accessible lakes in LAVO, Manzanita and Butte Lakes, which are currently under study. These lakes are young features formed from volcanogenic processes, have experienced moderate, catchment-level human impact through recreational activities and infrastructure development, and are potentially affected by regional impacts caused by climate change and anthropogenic activities. These and other LAVO lakes have also experienced the effects of geologically recent proximal volcanic eruptions and provide an interesting area to examine post-eruption lake recovery.

\section{Geology of the Lassen Volcanic Center}

Located at the southern end of the Cascade arc of volcanoes (fig. 4.1), the Lassen Volcanic Center (LVC) is part of an active volcanogenic landscape dominated by volcanic processes (Hoffman and others, 2005; Clynne and others, 2012). Cascade arc volcanoes are the product of upwelling magma generated by subduction zone magmatism resulting from the interaction of the Juan de Fuca, Explorer, and Gorda plate with the North American plate. Subduction is young, and relatively warm oceanic crust is being subducted at strong oblique angles relative to the North American plate (Clynne, 1993). The Gorda plate is the southernmost component of the Juan de Fuca plate system, and the interactions of this plate with North America have the most current bearing on subduction-zone related volcanic activity in the LVC. The eastern margin of the Gorda plate is being consumed in the Cascadian subduction zone at a rate of about $36-40 \mathrm{~mm} / \mathrm{yr}$ (Riddihough, 1984). Additionally, the Gorda plate also acts as a nonrigidly-deforming tectonic accommodation zone for the larger Juan de Fuca plate to the north and the Pacific plate to the south, likely resulting in changes in spreading rate (and subduction rate) driven by deformation (Chaytor and others, 2004).

${ }^{1}$ Department of Geological Sciences and Engineering, University of Nevada, Reno.

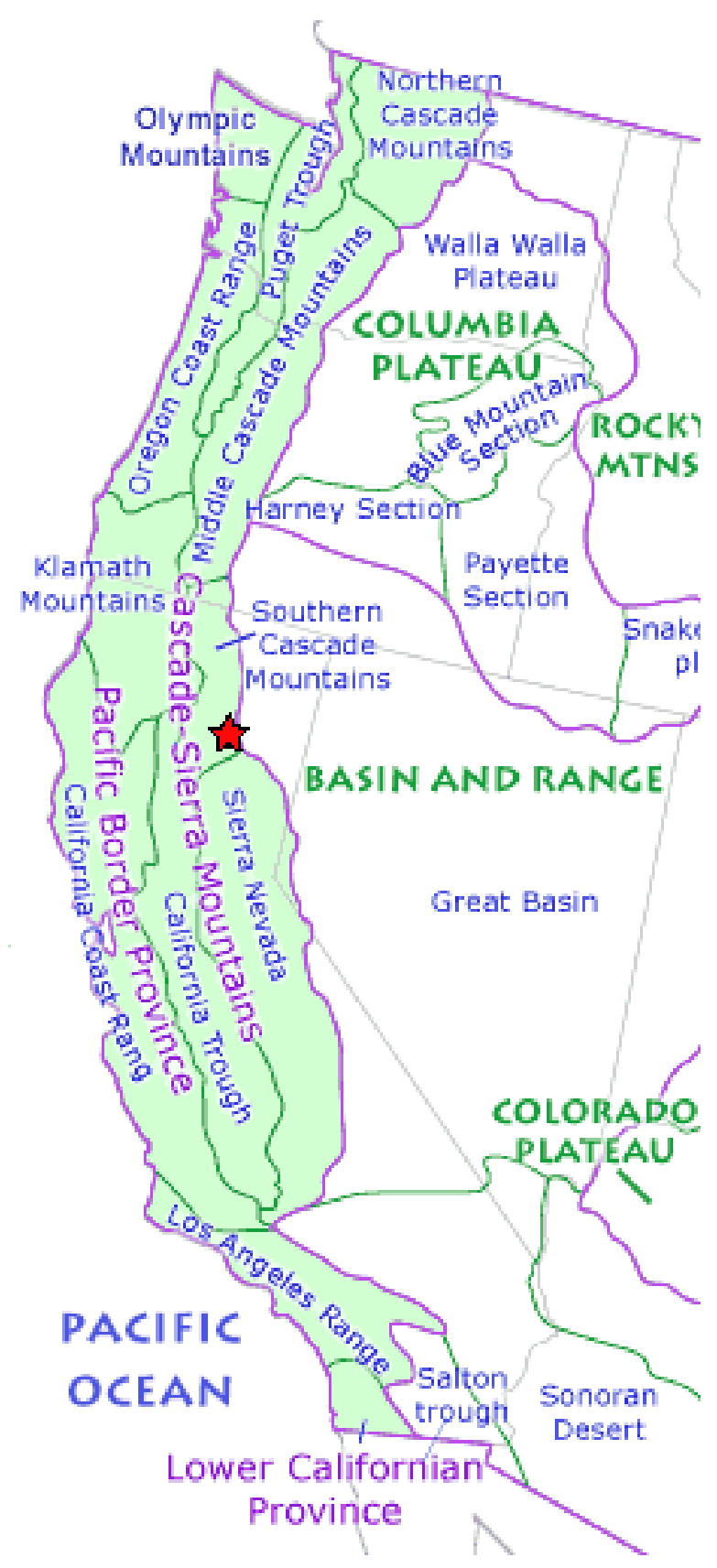

Figure 4.1. Major geologic provinces in the Western United States and the location of Lassen Volcanic National Park (red star). From http://geomaps.wr.usgs.gov/parks/province/pacifmt. html. 
The Lassen Volcanic Center consists of widely distributed vents and domes extending over an approximate $20 \mathrm{~km}$ north-south by an approximate 25 km east-west area, and encompasses Lassen Peak (Clynne and others, 2012). Volcanic centers are defined as the foci of long-lived (> $1 \mathrm{Ma}$ ), voluminous (few hundred cubic kilometers) volcanism (Clynne and Muffler, 2010). The Lassen Volcanic Center (about 825,000 years in age) is superimposed upon a background of regional scale basaltic-andesitic volcanism, and is the youngest of approximately five long-lived volcanic centers younger than about 3 Ma (Clynne, 1993).

Regional volcanoes have a wide range of forms (i.e., small cinder cones, shield volcanoes), and the result of regional volcanism is the construction of a large plateau of overlapping mafic volcanoes (Clynne and Muffler, 2010). Larger volcanic centers, including the LVC, have consisted of basaltic-andesite to andesite composite cones and silicic domes and flows. The evolution of the LVC is comprised of three stages of volcanism: (1) the Rockland caldera complex (825,000-610,000 years ago, a dacite domefield, (2) Brokeoff Volcano (590,000-385,000 years ago), an andesitic composite cone; and (3) the Lassen dome field, including Lassen Peak (300,000 years ago to present (Clynne, 1993; Clynne and Muffler, 2010). Some LVC eruptions, such as the emplacement of Chaos Crags, the eruption of the Cinder Cone, and the 1914-1917 eruptions of Lassen Peak have occurred in the last approximately 1,000 years. These events are of great interest because the volcanic features associated with these events are readily apparent and have directly affected multiple lakes in Lassen Volcanic National Park.

\section{Lassen Volcanic National Park Lakes}

There are at least 277 known lentic water bodies of varying depths, surface areas, and volumes scattered throughout Lassen Volcanic National Park (Hoffman and others, 2005). Most of these lakes exist in coniferous forests and mountainous topography at elevations between about $1,768 \mathrm{~m}$ and about 2,500 $\mathrm{m}$ falling into either the alpine zone (at or above the tree line) or sub-alpine zone (below the tree line). Lake formation is post-glacial, with some lakes being directly formed from glacial advance (i.e., Lake Helen, a cirque lake), some lakes existing in topographic lows within the volcanogenic and glacially-altered landscape (i.e, Widow Lake), and some lakes being formed as a direct result of volcanic activity (i.e., Butte Lake, Manzanita Lake) (Clynne and Muffler, 2010). Many of these lakes are situated in wilderness areas and can only be accessed on foot via trails. Several lakes (in designated non-wilderness areas) are accessible by paved or dirt road, however, no motorized craft are allowed on any lake within the park. Hard-bottomed craft (i.e., kayaks, rowboats) are only allowed on Manzanita Lake, Butte Lake, and Juniper Lake.

\section{Climate Change and Anthropogenic Impacts on Lakes in the Lassen Area}

Lakes in the Lassen region are located within an isolated volcanic highland along the Sierran-Cascade axis where warming temperatures (Cordero and others, 2011) and precipitation anomalies over that last century (Ault and St. George, 2010) have been reported. Schneider and others (2009) demonstrate a $0.15^{\circ} \mathrm{C}$ per year warming trend since about 1990 for Lake Almanor, located just south of Lassen Volcanic National Park. Clearly, increasing warming temperatures are a concern for aquatic ecosystems in the Lassen area. Data suggest that warming temperatures and climatic fluctuation is a major stress factor for alpine and sub-alpine lakes (Ruhland and others, 2008; Lotter and others, 2010). Environmental change initiates ecological shifts; therefore climatic warming is affecting lakes in diverse and complex ways in many geographic regions (Smol, 2010), and the extent of ecological response in lakes is unclear (Hobbs and others, 2010).

Another factor leading to fluctuations in environmental conditions is nutrient loading. In fact, it is likely that both climate change and anthropogenic impacts (nutrient loading) may be acting jointly to induce new ecological states in midlatitude alpine lakes (Hobbs and others, 2010; Holmgren and others, 2010). Research conducted by Holtgrieve and others (2011) suggests that anthropogenic nitrogen has probably influenced watershed nitrogen budgets across the northern hemisphere for over a century. Evidence of nutrient loading (by atmospheric deposition) driving ecological shifts in diatom communities is reported from sedimentary diatom assemblages in of high arctic lakes (Canada, Greenland, Norway) and in mid-latitude lakes of North America (Colorado Front Range, Beartooth Mountains). Holmgren and others (2010) report that sedimentary records from low-impact, N-sensitive, small lakes in the Norwegian high arctic show that since 1920, diatom floristic changes are tied to increased nutrient concentrations, and depleted nitrogen stable isotopes in sediment organic matter is consistent with atmospheric inputs from anthropogenic sources. In fact, lakes in the arctic and mid-latitude alpine lakes (high $\mathrm{N}$ deposition) exhibit the highest amount of diatom compositional turnover in the 20th century (Hobbs and others, 2010). A 400-year sediment record from Beartooth Lake (Wyoming) suggests a rapid change in diatom community structure (from small Fragilaria senso lato species to Fragilaria crotonensis) over the past decade that appears to be indicative of changes in thermal stratification patterns and increased nitrogen loading (Saros and others, 2003, 2005). Likewise, recent sediments from two alpine lakes in Rocky Mountain National Park exhibit a greater representation of mesotrophic diatoms and increasingly depleted $\delta^{15} \mathrm{~N}$, which is interpreted to represent 
ecological response to enhanced atmospheric deposition of fixed nitrogen from anthropogenic sources (Wolfe and others, 2003). In general, these studies point to some interesting relationships between the relative abundances of Asterionella formosa, Fragilaria crotonensis and potential nitrogen loading in western, subalpine lakes. Specifically, that increases in the abundances of these taxa are due to nitrogen loading (by atmospheric deposition) because in situ enrichment experiments have suggested that these taxa are abundant when $\mathrm{P}$ availability is low and the supply of silica and nitrogen are moderately high (Saros and others, 2005; Michel and others, 2006) for remote, low-impact systems. These relationships suggest that both $A$. formosa and F. crotonensis are good at competing for nitrogen in generally low-nutrient systems.

\section{Field Trip Road Log Details}

Information for all stops is in the order traveled during the trip. Stops for the trip occur within Lassen Volcanic National Park (California, USA) along HWY 89 or off of HWY 44. Mileage increases northward and eastward as the trip makes a loop up through and around LAVO. Mileage starts at 0 at the southwest entrance station to LAVO along HWY 89. Locations for field trip stops are clearly marked by signs and on park maps as points of interest. Figure 4.2 shows the locations of all stops and places of interest in the park that are discussed in this chapter.

\section{DAY 1}

\section{Trip Starts at Southwest Entrance to Lassen Volcanic National Park on HWY 89}

Park Entrance, HWY Mile 0: Upon entering the park, we will be driving north along HWY 89 from the KohmYah-mah-nee Visitor Center at the southwest entrance to LAVO. Note a good view of steep-sided canyons forming this flank of the Lassen Volcanic Center (LVC). We will examine hydrothermal features and geology of the LVC at Stop 1.

\section{Stop 1. Brokeoff Mountain and Sulphur Works, HWY Mile 1}

To the west is Brokeoff Mountain, an eroded remnant of a much larger andesitic, composite stratocone that was similar in volume to Mount Hood, Oregon (Clynne and others, 2012). Brokeoff Mountain (or Mt. Tehama) was active from about 590,000 to 385,000 years ago, had a basal diameter of about 12 km, was about 3,350 m high, and had a combined volume of about $80 \mathrm{~km}^{3}$ (Clynne, 1993; Clynne and others, 2012). The other remnants of the flanks of Brokeoff Mountain are Mt. Diller and Pilot Pinnacle, which are situated on the northwest rim, and Mount Conard, located on the east rim (fig. 4.2). The LVC hosts the most extensive hydrothermal system in the Cascade arc. Expressions of the LVC hydrothermal system are steam vents, hot springs, and the alteration of surface rocks by acid-sulfate alteration. The LVC hydrothermal system consists of a shallow, vapor-dominated reservoir underlain by a reservoir of $240{ }^{\circ} \mathrm{C}$, and recharge of the system occurs primarily through meteoric water in hightopography areas around the LVC (Clynne and others, 2003). The Sulfur Works area consists of steam-dominated features, such as mudpots and fumeroles. The warm to hot ground around Sulfur Works is covered with yellow and orange sulfates and native sulfur, and general alteration of the ground surface is apparent. The steam coming from Sulfur Works fumeroles and mudpots contains hydrogen sulfide $\left(\mathrm{H}_{2} \mathrm{~S}\right)$ that is oxidized at the surface and combines with water to produce sulfuric acid. The sulfuric acid weathers the surface rocks to produce kaolinite and opal silica, and the results of sulfateacid alteration is commonly seen along steep-sided areas of Mill Creek canyon, and other hydrothermally active areas of the LVC (Clynne and others, 2003, 2012).

HWY Mile 1 to 5.7: We will continue to drive north along HWY 89, gaining elevation up the eroded remnant flank of Brokeoff Mountain (Mt. Tehama). Note views of Emerald Lake, a tarn lake (about $30 \mathrm{~m}$ in depth) formed in a cirque created during the Pleistocene Tioga glaciation.

\section{Stop 2. Bumpass Hell, HWY Mile 5.7}

Bumpass Hell is the principal area of upflow and steam discharge from the Lassen hydrothermal system (Clynne and others, 2003). The hottest and most vigorous of hydrothermal features are found in this area, including Big Boiler-the largest fumerole in the park, and one of the hottest fumeroles in the world. The high-velocity steam emanating from Big Boiler has a measured temperature of $161^{\circ} \mathrm{C}$ (Clynne and others, 2003). The hydrothermal waters at Bumpass Hell are near the boiling point, and are typically acidic, however, the temperature and chemistry of the fumeroles, mudpots, and pools vary by season and with mixing of shallow, cooler ground water (i.e., from spring snowmelt) (Clynne and others, 2003).

HWY Mile 5.7 to 6.9: As we drive around the base of Lassen Peak, note Vulcan's Eye, a large outcrop of rhyodacite that is a prominent feature on the dacite dome visible from Lake Helen (fig. 4.3). 


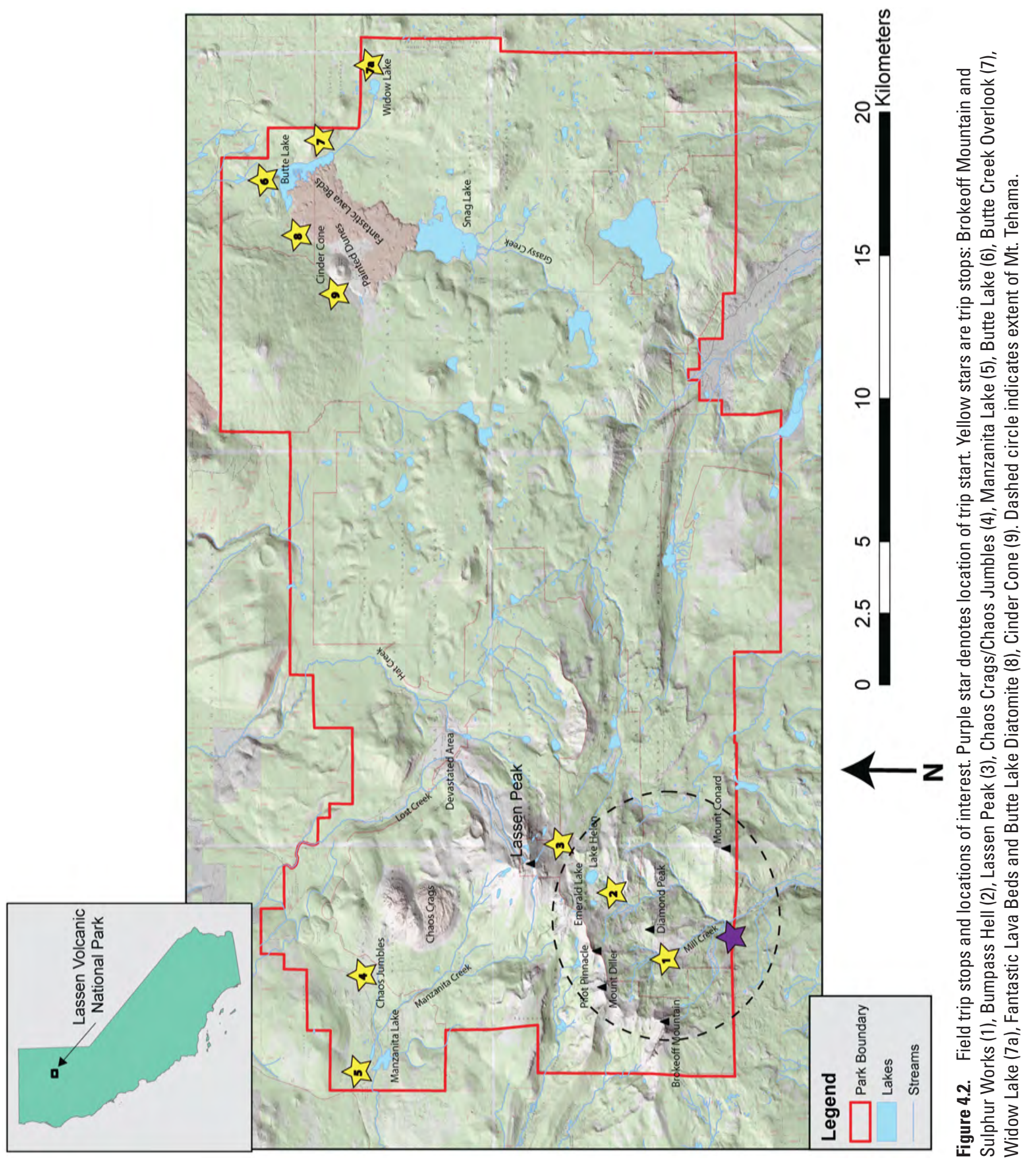




\section{Stop 3. Lassen Peak}

HWY Mile 6.9: Unlike other Cascade volcanoes, Lassen Peak is not a stratovolcano but is instead a large dacitic volcanic dome that has a complex phenocryst assemblage of mixedmagma origin. Lassen Peak formed about 27,000 years ago as a volcanic vent on the northern flank of Brokeoff Mountain (Turrin and others, 1998). Emplacement of the Lassen Peak dome began about $27 \mathrm{ka}$ before the latest Pleistocene glaciation (Tioga “Tahoe” glaciation, 17-20 ka), allowing a 10-km long glacier to form on the northeastern flank of the peak (Turrin and others, 1998). Lake Helen is a tarn lake formed in the cirque created by this glacier. The Lassen Peak eruptions of 1914-1917 produced pyroclastic flows and lahars that devastated regions of Lost Creek, Hat Creek and smaller drainages on the east, northern and western flanks of Lassen Peak. On May 22, 1915, Lassen Peak erupted with a vertical column of pumice, ash and hot gas $9 \mathrm{~km}$ into the atmosphere with fine ash falling as far away as Elko, Nevada $(450 \mathrm{~km}$ away) (Clynne and others, 2012).

HWY Mile 18.7: We will continue driving around the east side of Lassen Peak. On the northeastern flank of Lassen Peak is a $3-\mathrm{mi}^{2}$ area called the Devastated Area. Disturbance to this area was caused by pyroclastic flows and two lahars generated during the May 1915 eruptions of Lassen Peak. The lahars rushed down Lost Creek and flooded Hat Creek Valley.

\section{Stop 4. Chaos Crags/Chaos Jumbles}

HWY Mile 25.6: The Chaos Crags lava domes were emplaced approximately 1,050 years ago (Clynne and others, 2008). Approximately 325 years ago, a series of landslides broke off of Chaos Crags and flowed approximately $6 \mathrm{~km}$ forming Chaos Jumbles (Clynne and others, 2008; Clynne and Muffler, 2010).

\section{Stop 5. Manzanita Lake}

HWY Mile 28: Manzanita Lake (fig. 4.4, 1,790 m) is fed by Manzanita Creek with headwaters located on the northwestern flank of Lassen Peak and Chaos Crags. Manzanita Lake was formed approximately 325 years ago when a series of landslides (Chaos Jumbles) broke off of Chaos Crags and flowed approximately $6 \mathrm{~km}$ damming Manzanita Creek (Clynne and others, 2008; Clynne and Muffler, 2010). Manzanita Lake was dammed in 1913, which artificially raised the lake level by about $2 \mathrm{ft}$ (Clynne and others, 2012).

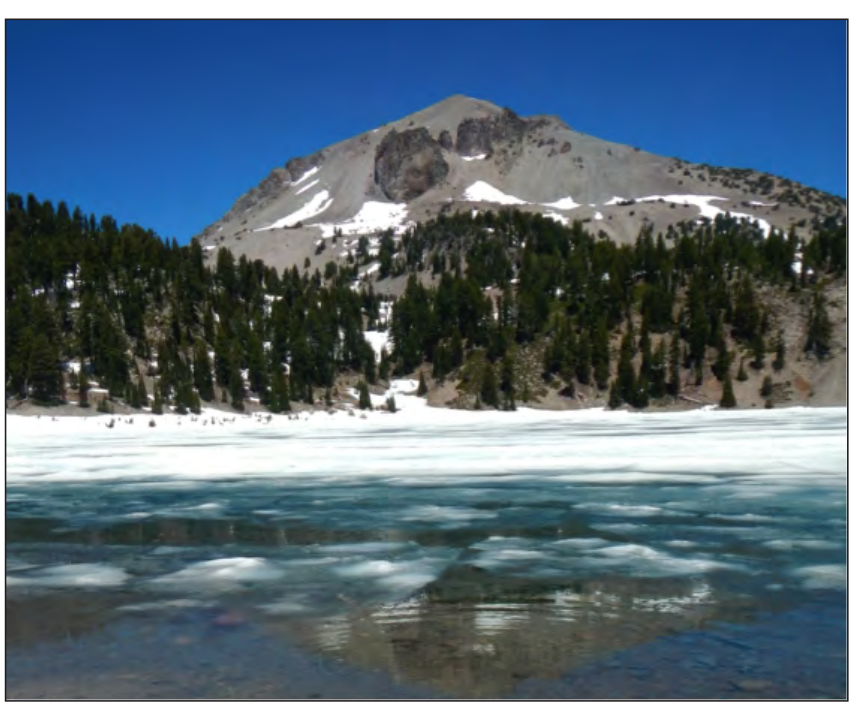

Figure 4.3. Lassen Peak with Vulcan's Eye visible from Lake Helen, June 2012. Photograph by Kerry Howard.

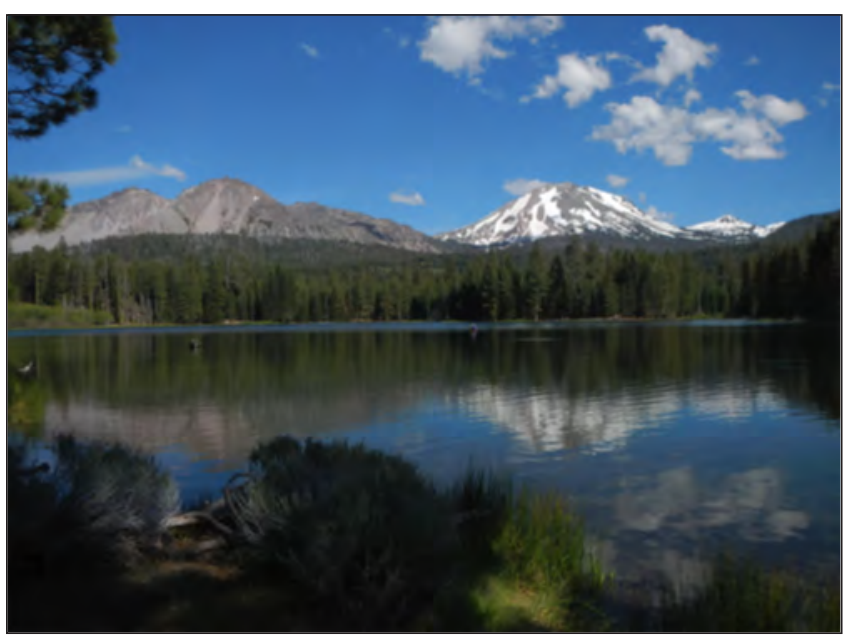

Figure 4.4. Manzanita Lake with Lassen Peak and Chaos Crags visible in the background, June 2014. Photograph by Kerry Howard. 
Manzanita Lake is a valuable recreational spot for anglers and visitors. Manzanita Creek continues past the dam and serves as the only outlet to Manzanita Lake. Manzanita Creek and Manzanita Lake are subject to lahar hazards associated with volcanic activity on Lassen Peak. Manzanita Lake exists within a drainage (Manzanita Creek) categorized as having high lahar or volcanically related flooding frequency (Clynne and others, 2012). Because the lake flows over the dam, any material entering the lake will raise the lake level and cause flooding downstream and large lahars have the potential to completely incorporate the lake.

During the May 1915 eruption, lahars occurred in the upper watershed and reached the headwaters of Manzanita Creek (Clynne and Muffler, 2010; Robinson and Clynne, 2012). On May 24, 1915, eyewitnesses climbed up towards Loomis Peak on the northwestern flank of Lassen Peak. Eyewitnesses noted four streams of mud on the western side of Lassen Peak that flowed down toward Manzanita Lake and recorded the following information:

"the greater part of the mud flow on the west side ran out on top of the snow while the water disappeared in the snow, and this prevented the greater part of the mud flow from reaching the lake. Manzanita Lake is filling very fast these days on account of there being a constant wash of sandy material of the light pumice variety into the lake whenever the flow of water is very much above the low water mark in the creek.” (Loomis, 1926)

Eyewitness accounts also speak of mud streams entering Manzanita Lake during a small eruption in July 1915 that followed the main eruptions in May 1915 (Loomis, 1926).

Manzanita Lake has a surface area of $0.18 \mathrm{~km}^{2}$, a watershed area of about $30 \mathrm{~km}^{2}$ (fig. 4.5), and maximum depth of 9-10 m. Hydraulic residence time is short; roughly 119 days, and is derived from lake volume $\left(1.0 \times 10^{6} \mathrm{~m}^{3}\right)$ and estimates of stream inflow (about $7 \mathrm{ft}^{3} / \mathrm{s}$ ) and outflow (about $3 \mathrm{ft}^{3} / \mathrm{s}$ ) that were made from May 2014 sampling data. Limnological sampling in 2012-2014 suggests that Manzanita Lake exhibits stable thermal stratification in the summer months, which is unusual given the shallow depth (about $10 \mathrm{~m}$ ), but possibly supported by the morphometry of the lake basin and inputs of cold snowmelt from the flank of Lassen Peak. The lake is a moderately conductive $(100-114 \mu \mathrm{S})$, mesotrophic system with secchi depths ranging from $8 \mathrm{~m}$ to the bottom (about $10 \mathrm{~m}$ ). Total phosphorus (TP) ranges from 15 to $25 \mathrm{ppb}$ and dissolved inorganic nitrogen (DIN) from 2 to $15 \mathrm{ppb}$, with ammonium in the epilimnion being the largest contributor. A high concentration of silica (Si) in surface-water inputs (34 mg/L) to Manzanita Lake likely reflects the rhyodacitic bedrock geology and large drainage

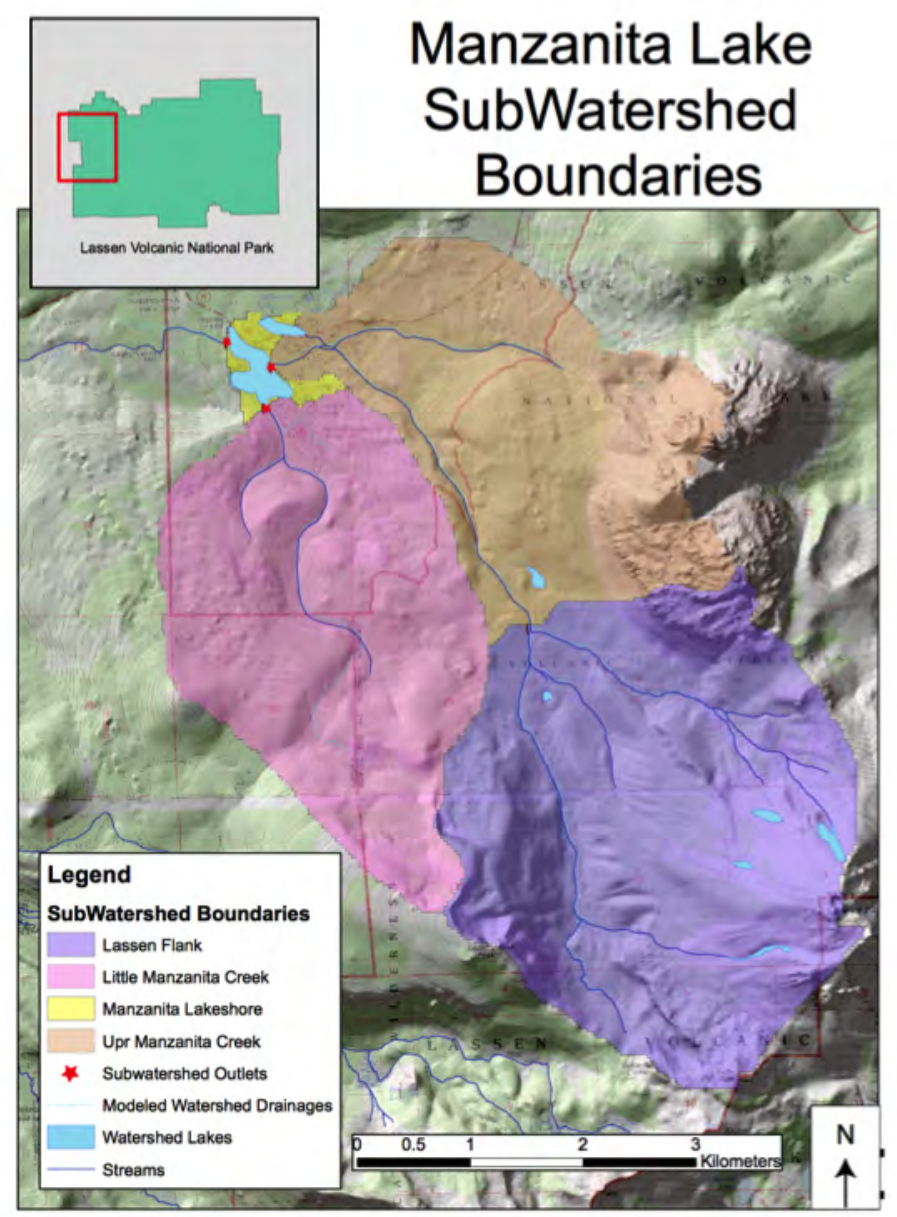

Figure 4.5. Manzanita Lake watershed with subwatershed boundaries. Total watershed area is about $30 \mathrm{~km}^{2}$.

ratio (164) of the watershed. Variations in Si concentration in the lake seem to be coupled with diatom production. During the sampling period, Manzanita Lake was dominated by diatom blooms throughout the summer and fall months (fig. 4.6). There is a seasonal succession in the diatom species present, with Asterionella formosa (an N-sensitive species) dominant in the spring, transitioning to a dominance of Fragilaria crotonensis (also N-sensitive) in the summer months, and then to a mixed dominance of Fragilaria crotonensis and Aulacoseira granulata v. angustissima species in the fall. Persistence of diatom species with moderate to high Si requirements throughout the summer is atypical and may be related to the resource ratio requirements of these species, high Si (11-29 mg/L in lake), TP, and DIN concentrations. These data provide a modern baseline with which to interpret down-core changes in diatom composition and diversity over the last century from lake sediment cores. 

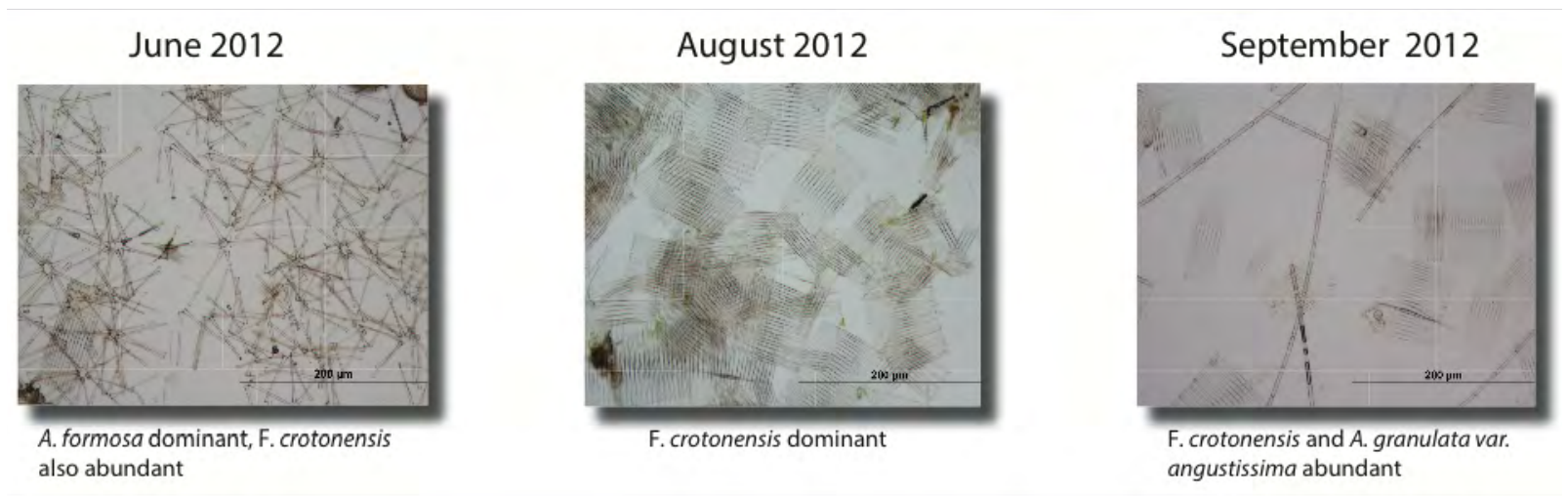

Figure 4.6. Seasonal diatom community composition in Manzanita Lake. Image provided by Kerry Howard.

\section{DAY 2}

Trip Continues from Old Station, California at the Junction between HWY 89 and HWY 44

\section{Stop 6. Butte Lake; HWY Mile 59.5}

Butte Lake (fig. 4.7, 1,850 m) is situated amidst the Fantastic Lava Beds near the Cinder Cone. The maximum depth of the lake is approximately $13-15 \mathrm{~m}$, and the lake is thermally stratified during summer months. In January 2012, Butte Lake was completely iced-over with the ice thickness being on the order of about $1 \mathrm{~m}$ so that people could safely skate out in the middle of the lake. Butte Lake was ice-free as of June 2012 (and possibly earlier). Butte Lake is a remnant of a larger lake that was partly filled by lava flows during the eruption of the Cinder Cone approximately 348 years ago (A.D. 1666) (Clynne and others, 2000). Butte Lake is mainly supplied by water seeping beneath the Fantastic Lava Beds from Snag Lake, which was formed when the Painted Dunes lava flow (associated with the Cinder Cone) blocked Grassy Creek, a stream draining the central highland of LAVO (Clynne and others, 2000). Similar to Manzanita Lake, Butte Lake phytoplankton is dominated by diatom species, although a seasonal succession of species has been observed. In the spring, Butte Lake is dominated by two $\mathrm{N}$-sensitive species, Asterionella formosa and Fragilaria crotonensis, followed by F. crotonensis and araphid chains in the summer, and replaced by Fragilaria tenera-nanana group in the fall.

We will walk along the east shore of Butte Lake to an overlook near Butte Creek.

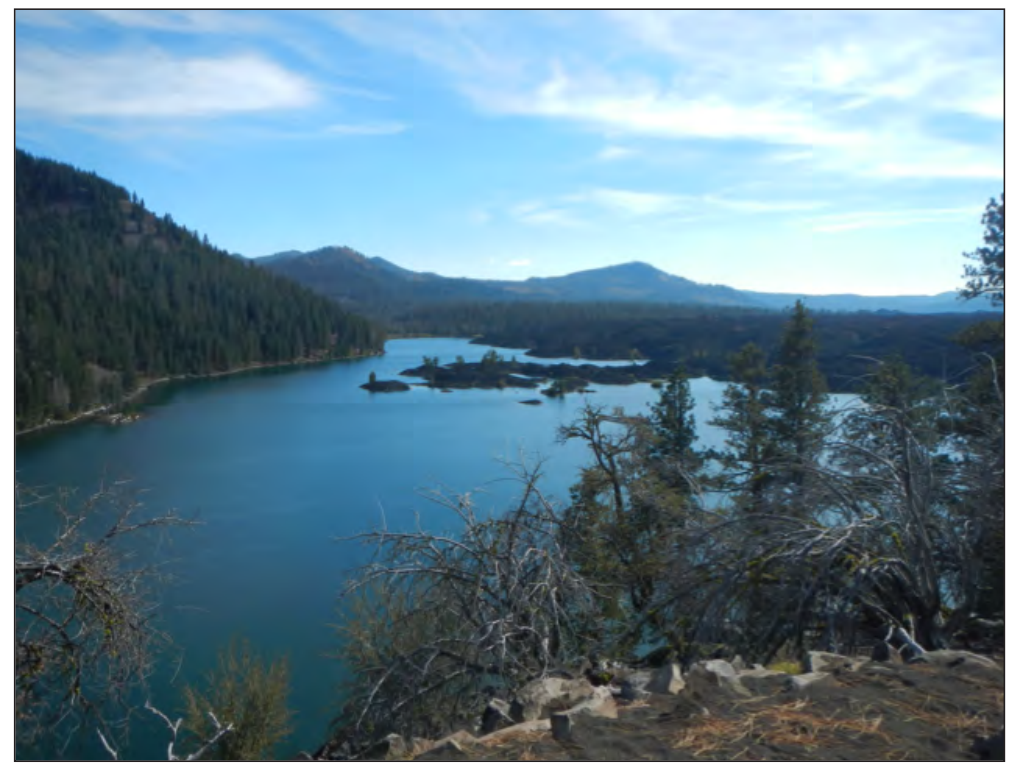

Figure 4.7. Butte Lake, June 2012. Photograph by Kerry Howard. 


\section{Stop 7. Butte Creek Overlook}

7a. Widow Lake: We will not have time to hike up to Widow Lake (fig. 4.8, 2,084 m), but it is a small, low impact system in the Butte Lake watershed that has been cored and sampled for limnology. Widow Lake sits on a volcanic highland beyond a ridge about $234 \mathrm{~m}$ above, and about $2 \mathrm{~km}$ distance from the southeastern shore of Butte Lake. The maximum lake depth is 9-10 m, and the lake water column appears to be mixed throughout the spring-fall. Widow Lake, a higher elevation more remote site, has abundant diatoms, although a slightly different seasonal succession than Manzanita or Butte Lakes. Starting with abundant Tabellaria and F. tenera-nanana group in spring, these species are followed by dominance of F. crotonensis and Tabelleria species in the summer, and F. tenera-nanana group in the fall (fig. 4.9).

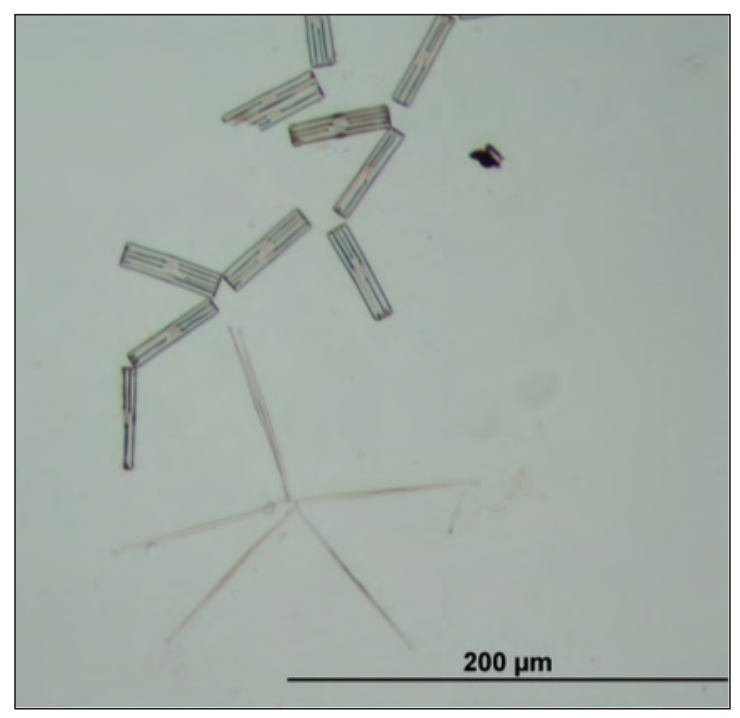

Figure 4.9. Tabellaria and Fragilaria tenera-nanana group diatom species in Widow Lake. Image provided by Kerry Howard.

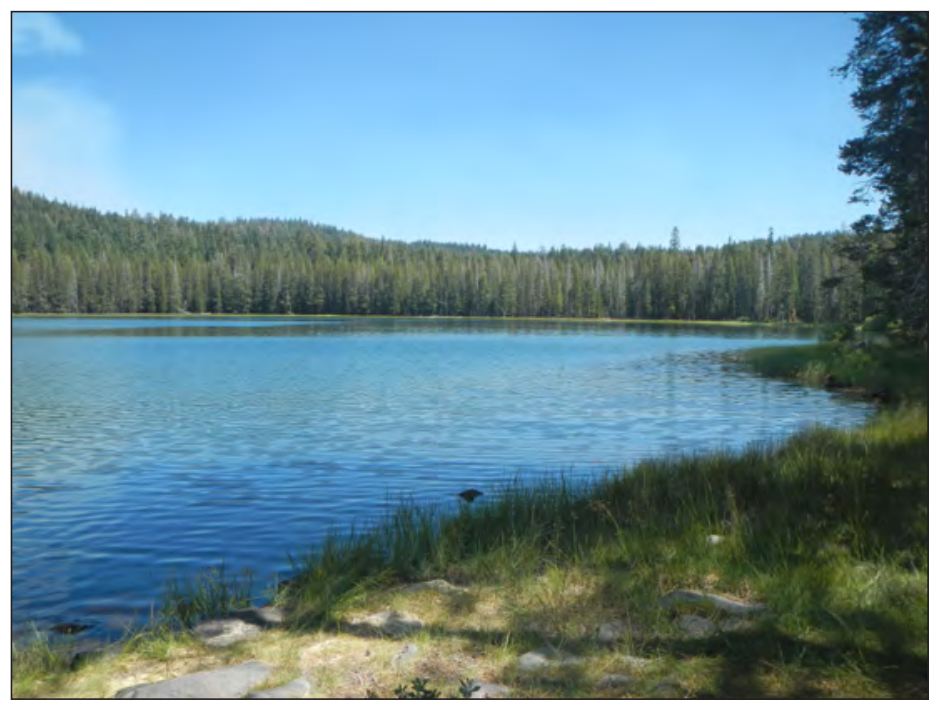

Figure 4.8. Widow Lake, June 2012. Photograph by Kerry Howard.

Widow Lake is likely supported mainly by groundwater and surface runoff from snow melt in the spring. There are no consistent surface inputs or outputs, but topography and surficial features suggest ephemeral inputs during snowmelt and intermittent output toward Butte Lake depending on water level in the lake. Widow Lake is accessible on foot via hiking trail (about $4 \mathrm{mi}$ ) from the Butte Lake campground. Widow Lake is surrounded by glacial sediments (Clynne and Muffler, 2010) and is therefore likely a post-glacial lake, formed in a topographic low. Widow Lake was probably affected by the eruption of the Cinder Cone in A.D. 1666, and ash was likely deposited in and around the lake at depths of 4-10 in. (Clynne and others, 2000). The Huffer Fire, ignited by lightening, occurred from July 30, 1997, to August 20, 1997, and burned approximately 2,290 acres and was eventually contained along the southwestern shore of Widow Lake (Nps and Usdafs, 1998). 
Stop 8. Fantastic Lava Beds and Butte Lake Diatomite

In about 1666 A.D., five basaltic-basaltic andesite lava flows and two cinder cones were erupted in the northeastern corner of the park (Sheppard and others, 2009) creating the Cinder Cone and Fantastic Lava Beds areas (fig. 4.10). This eruption produced a tephra deposit covering about $100 \mathrm{~km}^{2}$ (Heiken, 1978), and the five lava flows cover approximately $8.4 \mathrm{~km}^{2}$ (Clynne and others, 2012).

A larger lake, precursor to the modern Butte Lake, was productive and dominated by diatom species, which is evidenced by the presence of diatomite found along the margins of the Fantastic Lava Beds (fig. 4.10) and above the high water elevation of the modern lake along the southeastern lake shore (Clynne and others, 2000). The diatomite (lake bottom sediment from the Butte Lake precursor) consists largely of heavily silicified, planktonic or meroplanktonic, centric diatoms of the genus Aulacoseira (fig. 4.11), although pennate diatom genera are also present. A lack of exposed pillow basalts and the fact that the diatomite is found along the margins of the Fantastic Lava Beds, as well as squeezed between the flows in some locations, suggests that the lake was not deep enough to completely accommodate the lava flows, as the lava flows appear to have scoured the lakebed.

\section{Stop 9. Hike to Cinder Cone (optional)}

Composed of loose scoria, this 700-ft high cone erupted in the mid-1600s (Clynne and others, 2000; Sheppard and others, 2009), producing both the Painted Dunes Lava flows and Fantastic Lava Beds (fig. 4.10). Cinder Cone also produced a widespread ash deposit that is still visible 8-10 mi from the cone (Clynne and others, 2000).

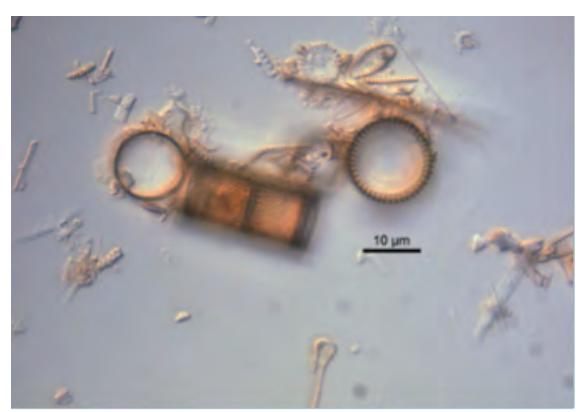

Figure 4.11. Aulacoseira species in Butte Lake diatomite. Image provided by Kerry Howard. 


\section{References Cited}

Ault, T.R., and St. George, S., 2010, The magnitude of decadal and multidecadal variability in North American precipitation: Journal of Climate, v. 23, p. 842-850.

Chaytor, J., Goldfinger, C., Dziak, R., and Fox, C., 2004, Active deformation of the Gorda plate: Constraining deformation models with new geophysical data: Geology, v. 32, no. 4, p. 353-356.

Clynne, M.A., 1993, Geologic studies of the Lassen Volcanic Center, Cascade Range, California: University of California, Santa Cruz, 808 p.

Clynne, M.A., Champion, D.E., Trimble, D.A, Hendley, J.W, II, and Stauffer, P.H., 2000, How old is the cinder cone?Solving a mystery in the Lassen Volcanic National Park: U.S. Geological Survey Fact Sheet 023-00, 4 p.

Clynne, M.A., Christiansen, R.L., Trimble, D.A., and McGeehin J.P., 2008, Radiocarbon dates from volcanic deposits of the Choas Crags and Cinder Cone eruptive sequences and other deposits, Lassen Volcanic National Park and vicinity, California: U.S. Geological Survey OpenFile Report 02-290, 10 p.

Clynne, M.A., Janik, C.J., and Muffler, L.J.P., 2003, “Hot Water" in Lassen Volcanic National Park-fumaroles, steaming ground, and boiling mudpots: U.S. Geological Survey Fact Sheet 101-02, 4 p.

Clynne, M.A., and Muffler, L.J.P., 2010, Geologic map of Lassen Volcanic National Park and vicinity, California: U.S. Geological Survey Scientific Investigations Map 2899, 3 sheets, scale 1:50,000.

Clynne, M.A., Robinson, J.E., Nathenson, M., and Muffler, L.J.P., 2012, Volcano hazards assessment for the Lassen region, northern California: U.S. Geological Survey Scientific Investigations Report 2012-5176-A, 47 p., 1 plate, scale 1:200,000.

Cordero, E.C., Kessomkiat, W., Abatzoglou, J., and Mauget, S.A., 2011, The identification of distinct patterns in California temperature trends: Climatic Change, v. 108, p. 357-382.

Heiken, G., 1978, Characteristics of tephra from the Cinder Cone, Lassen Volcanic National Park, California: Bulletin of Volcanology, 41-2, p. 119-130.

Hobbs, W.O., Telford, R.J., Birks, H.J.B., Saros, J.E., Hazewinkle, R.R.O., Perren, B.B., Saulnier-Talbot, E., and Wolfe, A.P., 2010, Quantifying recent ecological changes in remote lakes of North America and Greenland using sediment diatom assemblages: PLoS ONE 5(4): e10026.
Hoffman, R.L., Currens, C.R., and Madej, M.A., 2005, Klamath Network Water Quality Report (Phase II): U.S. Geological Survey, 154 p.

Holmgren, S., Bigler, C., Ingolfsson, O., and Wolfe, A.P., 2010, The Holocene-Anthropocene transition in lakes of western Spitsbergen, Svalbard (Norwegian High Arctic): climate change and nitrogen deposition: Journal of Paleolimnology, v. 43, p. 393-412.

Holtgrieve, G.W., and others, 2011, A coherent signature of anthropogenic nitrogen deposition to remote watersheds of the Northern Hemisphere: Science, v. 334, no. 6062, p. $1,545-1,548$.

Howard, K.L., 2013, Unpublished observations-Fieldwork in Lassen Volcanic National Park: Department of Geological Sciences and Engineering: University of Nevada, Reno.

Loomis, B.F., 1926, Pictorial History of the Lassen Volcano, 4th rev. ed.: National Park Service.

Lotter, A.F., Pienitz, R., and Schmidt, R., 2010, Diatoms as indicators of environmental change in subarctic and alpine regions, in Smol, J.P. and Stoermer, E.F. [eds.], The Diatoms: Applications for the Environmental and Earth Sciences, Cambridge University Press, p. 231-248. .

Michel, T., Saros, J., Interlandi, S., and Wolfe, A., 2006, Resource requirements of four freshwater diatom taxa determined by in situ growth bioassays using natural populations from alpine lakes: Hydrobiologia, v. 568: p. 235-243.

Nps, and Usdafs, 1998, Huffer Fire: Review of Management Actions: National Park Service, $51 \mathrm{p}$.

Riddihough, R.P., 1984, Recent movements of the Juan de Fuca plate system: Journal of Geophysical Research, v. 89, issue B8, p. 6980-6994.

Robinson, J.E., and Clynne, M.A., 2012, Lahar hazard zones for eruption-generated lahars in the Lassen volcanic center, California: U.S. Geological Survey Scientific Investigations Report 2012-5176-C, 13 p.

Ruhland, K., Paterson, A.M., and Smol, J.P., 2008, Hemispheric-scale patterns of climate-related shifts in planktonic diatoms from North American and European lakes: Global Change Biology, v. 14, p. 2,740--2,754.

Saros, J.E., Interlandi, S.J., Wolfe, A.P., and Engstrom, D.R., 2003, Recent changes in the diatom community structure of lakes in the Beartooth Mountain Range, U.S.A.: Arctic, Antarctic, and Alpine Research, v. 35, no. 1, p. 18-23. 
Saros, J.E., Michel, T.J., Interlandi, S.J., and Wolfe, A.P., 2005, Resource requirements of Asterionella formosa and Fragilaria crotonensis in oligotrophic alpine lakes: implications for recent phytoplankton community reorganizations: Canadian Journal of Fisheries and Aquatic Sciences, v. 62, p. 1,681-1,689.

Schneider, P., Hook, S.J., Radocinski, R.G., Corlett, G.K., Hulley, G.C., Schladow, S.G., Steissberg, T. E., 2009, Satellite observations indicate rapid warming trend for lakes in California and Nevada: Geophysical Research Letters, v. 36, L22402, 6 p.

Sheppard, P.R., Ort, M.H., Anderson, K.C., Clynne, M.A., and May, E.M., 2009, Multiple dendrochronological responses to the eruption of Cinder Cone, Lassen Volcanic National Park, California: Dendrochronologia, v. 27, p. 213-221.
Smol, J.P., 2010, The power of the past: using sediments to track the effects of multiple stressors on lake ecosystems: Freshwater Biology, v. 55, p. 43-59.

Turrin, B., Christianson, R.L., Clynne, M.A., Champion, D.E., Gerstel, W.J., Muffler, L.J.P., and Trimble, D.A., 1998, Age of Lassen Peak, California, and implications for the ages of late Pleistocene glaciations in the southern Cascade Range: Geological Society of America, Special Paper 505.

Wolfe, A.P., Van Gorp, A., and Baron, J.S., 2003, Recent ecological and biogeochemical changes in alpine lakes of Rocky Mountain National Park (Colorado, USA): a response to anthropogenic nitrogen deposition: Geobiology v. 1, issue 2, p. 153-168. 
Publishing support provided by the U.S. Geological Survey Science Publishing Network, Tacoma Publishing Service Center

For more information concerning the research in this report, contact the Chief, Water Science Field Team

U.S. Geological Survey

520 North Park Avenue

Tucson, Arizona 85721

http://az.water.usgs.gov/ 
